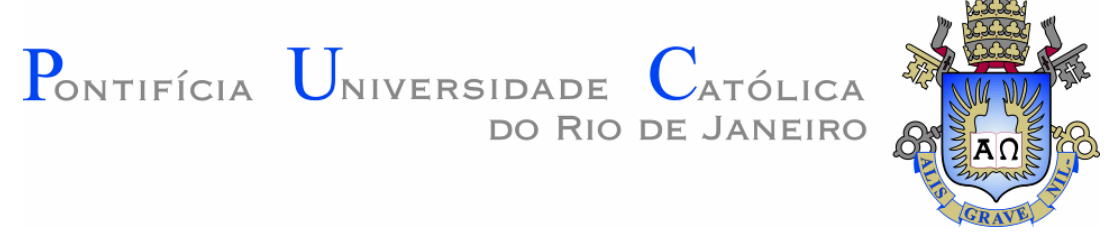

Alecir Francisco de Carvalho

Interações, Significados e Sentidos em Ambientes Virtuais de Aprendizagem

Tese de Doutorado

Tese apresentada ao Programa de Pós-graduação em Design da PUC-Rio como requisito parcial para obtenção do grau de Doutor em Design.

Orientadora: Profa. Jackeline Lima Farbiarz Coorientador: Prof. Alexandre Farbiarz 
Pontifícia Universidade C $_{\text {atólica }}$

DO RIO DE JANEIRO

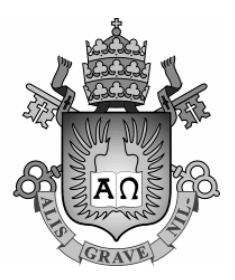

Alecir Francisco de Carvalho

\section{Interações, Significados e Sentidos em Ambientes \\ Virtuais de Aprendizagem}

Tese apresentada ao Programa de Pós-graduação em Design da PUC-Rio como requisito parcial para obtenção do grau de Doutor em Design. Aprovada pela Comissão Examinadora abaixo assinada.

\section{Profa. Jackeline Lima Farbiarz} Orientadora

Departamento de Artes \& Design - PUC-Rio

Prof. Alexandre Farbiarz

Coorientador Universidade Federal Fluminense - UFF

Profa. Vera Lúcia Moreira dos Santos Nojima Departamento de Artes \& Design - PUC-Rio

Prof. Guilherme de Almeida Xavier Departamento de Artes \& Design - PUC-Rio

Profa. Marli Teresinha Everling Universidade da Região de Joinville - Univille

Profa. Eliane Bettocchi Godinho Universidade Federal de Juiz de Fora - UFJF

Profa. Monah Winograd

Coordenadora Setorial do Centro de Teologia e Ciências Humanas - PUC-Rio

Rio de Janeiro, 23 de março de 2018 
Todos os direitos reservados. É proibida a reprodução total ou parcial do trabalho sem autorização da universidade, do autor e dos orientadores.

\section{Alecir Francisco de Carvalho}

Graduou-se em Design pela Escola de Design (ED/UEMG). É pós-graduado em Educação Ambiental pela Faculdade de Educação da UEMG. É mestre em Design pela (ED/UEMG) e pesquisador do grupo de pesquisa Design na Leitura de Sujeitos e Suportes em Interação- DeSSIn do Laboratório Linguagem, Interação e Construção de sentidos/Design- LINC do Departamento de Artes e Design da PUC-Rio.

Ficha Catalográfica

Carvalho, Alecir Francisco de

Interações, significados e sentidos em ambientes virtuais de aprendizagem / Alecir Francisco de Carvalho ; orientadora: Jackeline Lima Farbiarz ; coorientador: Alexandre Farbiarz. - 2018.

193 f. : il. color. ; $30 \mathrm{~cm}$

Tese (doutorado)-Pontifícia Universidade Católica do Rio de Janeiro, Departamento de Artes e Design, 2018.

Inclui bibliografia

1. Artes e Design - Teses. 2. Design e educação a distância. 3. Ambientes virtuais de aprendizagem. 4. Significados e sentidos em AVAs. I. Farbiarz, Jackeline Lima. II. Farbiarz, Alexandre. III. Pontifícia Universidade Católica do Rio de Janeiro. Departamento de Artes e Design. IV. Título. 


\section{Agradecimentos}

Primeiramente, agradeço a Deus, por se fazer presente em minha vida, e a minha família, que ao longo dos anos tem me apoiado para seguir sempre em frente.

À minha orientadora, Jackeline Lima Farbiarz, por ter guiado meus passos durante esses quatro anos, mostrando-me com sabedoria, atenção e humildade que a vida precisa ser vivida com leveza, generosidade e amor ao próximo.

Aos professores Alexandre Farbiarz e Guilherme Xavier, pelo apoio durante as dificuldades encontradas na pesquisa e por serem exemplo de dedicação aos estudos e pesquisas no campo do Design e das Mídias.

Aos participantes voluntários da pesquisa, que se dispuseram a doar parte do seu tempo e gentilmente colaborar com a pesquisa respondendo ao questionário e concedendo entrevistas. Não posso listá-los para que as identidades sejam totalmente preservadas.

Aos professores integrantes da banca examinadora com suas valiosas considerações, oportunizando o aprofundamento no âmbito do Design e da Educação a Distância.

Aos professores do Programa de Pós-Graduação em Design da Pontifícia Universidade Católica do Rio de Janeiro - PUC-Rio, por proporcionarem enriquecedoras discussões em sala de aula e por contribuírem para a minha formação durante este período.

Aos amigos integrantes do Laboratório Linguagem Interação e Construção de Sentidos do Departamento de Artes e Design da Pontifícia Universidade Católica do Rio de Janeiro - PUC-Rio. 
Aos amigos Cleder Tadeu Antão da Silva, Sérgio Luciano da Silva, Josemir Almeida Barros, José Júlio de Carvalho Júnior, Jacqueline da Silva Gonçalves, Wander Augusto Silva, Felipe Domingues Machado Melo, Fabricio Andrade Pereira, pelas palavras de incentivo durante todo o longo processo de desenvolvimento deste estudo e por me proporcionarem grande entusiasmo para iniciar o programa de Pós-graduação. Agradeço igualmente aos demais amigos, familiares e colegas, a quem peço desculpas por não listar um a um (seria o meu desejo), mas se sintam homenageados.

Ao professor e amigo Luiz Carlos Paixão, que me concebeu ensinamentos de forma crítica e reflexiva no campo da História e me emprestou livros no momento em que mais precisava durante a minha formação inicial.

Aos amigos que contribuíram nas fases finais da pesquisa: Walesson Gomes da Silva, Cynthia Macedo Dias, Weslei Clem de Menezes, Danilo Gomes Ribeiro, Pollyanna Oliveira Ramos e Vinicius José Shindo Mitchell.

Aos estudantes da turma 2014-2018 do Programa de Pós-graduação - Doutorado em Design - PPGD, pela excelente relação pessoal que criamos, a qual espero que não se perca. De modo especial a Cláudia Fátima Campos e Raquel Pereira Canaan, companheiras na travessia entre Belo Horizonte - MG e Rio de Janeiro - RJ.

Aos colegas professores da Faculdade de Educação e da Escola de Design da UEMG, pelas parcerias em estudos e pesquisas e por acreditarem no potencial do Design e da Educação.

Agradeço a CAPES, FAPEMIG e PUC-Rio, pela concessão de bolsa que tornou possível o desenvolvimento desta pesquisa.

A todos que, de alguma forma, contribuíram para a execução desta pesquisa. 


\section{Resumo}

Carvalho, Alecir Francisco; Farbiarz, Jackeline Lima. Interações, Significados e Sentidos em Ambientes Virtuais de Aprendizagem. Rio de Janeiro, 2018. 193p. Tese de Doutorado - Departamento de Artes \& Design, Pontifícia Universidade Católica do Rio de Janeiro.

A presente tese é um estudo acerca das aproximações e distanciamentos entre os campos do Design e da Educação a Distância $(\mathrm{EaD})$ e uma análise sobre as concepções dos agentes da $\mathrm{EaD}$ (gestores, docentes, designers e designers instrucionais) acerca do que potencializa o Ambiente Virtual de Aprendizagem (AVA) como suporte de significação e interação que media a relação educadoreducando. Assumimos como marco teórico nesta pesquisa os conceitos de interação abordados por Jean Piaget e Lev Vygotsky e as concepções de Significados e Sentidos abordados por Mikhail Bakhtin. O foco analítico recai sobre as interseções possíveis entre esses dois campos e de modo particular sob a perspectiva da construção e configuração de Ambientes Virtuais de Aprendizagem. Argumentamos na tese que as aproximações entre Design e Educação a Distância podem contribuir para o surgimento de novas práticas de ensino e favorecer a interação e a construção de sentidos em suportes e sistemas em situações de uso no contexto das comunidades de ensino-aprendizagem. Deste modo, a presente pesquisa tem como objetivo geral compreender as concepções dos agentes da Educação a Distância acerca do que potencializa o Ambiente Virtual de Aprendizagem como suporte de significação e interação, sendo facilitador de práticas mediadoras na relação educador-educando. Sendo assim, presume-se que tais agentes da $\mathrm{EaD}$ são aqueles sujeitos envolvidos diretamente no planejamento, na execução e no acompanhamento de cursos na modalidade a distância, tais como gestores, docentes, designers, designers instrucionais, discentes, entre outros. Considera-se, assim, o campo da EaD como um segmento que tem despontado na contemporaneidade e demandado a incorporação de tecnologias digitais de informação e comunicação como recursos fundamentais para a expansão dessa modalidade de ensino. Trata-se de uma investigação conduzida pela pergunta que 
questiona quais as concepções dos agentes da Educação a Distância acerca do que potencializa o AVA como suporte de significação e interação. Em vista disso, por meio desta pesquisa, foi possível constatar que as instituições investigadas optam pelo uso de recursos comumente reconhecidos, demonstrando uma escassez de alternativas na produção e apropriação de novos AVAs no contexto de ensino do Design. Também foi possível reconhecer, por meio de nossa análise preliminar descritiva e comparativa, as potencialidades e limites em cinco ambientes virtuais de Ambientes Virtuais de Aprendizagem mais utilizados no mundo: Moodle, Blackboard, EDX, Cousera e Edmodo.

\section{Palavras-chave}

Design e Educação a Distância; Ambientes Virtuais de Aprendizagem; Significados e Sentidos em AVAs. 


\section{Abstract}

Carvalho, Alecir Francisco; Farbiarz, Jackeline Lima (Advisor). Interactions, Meanings and Senses in Virtual Learning Environments. Rio de Janeiro, 2018. 193p. Tese de Doutorado - Departamento de Artes \& Design, Pontifícia Universidade Católica do Rio de Janeiro.

The present thesis is a study about the approximations and distances between the fields of Design and Distance Education and an analysis of the conceptions of Distance Education agents (managers, teachers, designers and instructional designers) about what enhances the Virtual Learning Environment (VLE) as a support of signification and interaction that mediates the educator-educating relationship. We assume as theoretical framework in this research the concepts of interaction addressed by Jean Piaget and Lev Vygotsky and the conceptions of Meanings and Senses addressed by Mikhail Bakhtin. The analytical focus falls on the possible intersections between these two fields and particularly from the perspective of the construction and configuration of Virtual Learning Environments. We argue in the thesis that the approaches between Design and Distance Education can contribute to the emergence of new teaching practices and favor the interaction and the construction of meanings in supports and systems in situations of use in the context of the teaching-learning communities. The present research has as general objective to understand the concepts of the agents of Distance Education about what enhances the Virtual Learning Environment as a support of meaning and interaction and facilitates mediating practices in the educator-educating relationship. Thus, it is presumed that such agents of Distance Education are those subjects directly involved in the planning, execution and follow-up of courses in the distance modality, such as managers, teachers, designers, instructional designers, students, among others. Thus, the field of Distance Education is considered as a segment that has emerged in contemporary times and demanded the incorporation of digital information and communication technologies as fundamental resources for the expansion of this type of teaching. It is an investigation conducted by the question that questions the conceptions of the 
agents of the Distance Education about what potentiates the VLE as a support of signification and interaction. In view of this, through this research, it was possible to verify that the investigated institutions opt for the use of commonly recognized resources, demonstrating a shortage of alternatives in the production and appropriation of new VLE $s$ in the context of Design teaching. It was also possible to recognize, through our preliminary descriptive and comparative analysis, the potentialities and limits in five virtual environments of Virtual Learning Environments most used in the world: Moodle, Blackboard, EDX, Cousera and Edmodo.

\section{Keywords}

Design and Distance Education; Virtual Learning Environments; Meanings and Senses in AVAs. 


\section{Sumário}

1 Introdução

2 Aspectos conceituais da pesquisa e as relações possíveis entre Educação a Distância e Design

2.1 Aspectos conceituais da Educação a Distância 34

2.2 Aspectos conceituais do Design 38

2.3 Relações entre Educação a Distância e Design e as possíveis repercussões em AVAs

2.4 Ambientes Virtuais de Aprendizagem: iniciativas brasileiras 43

2.4.1 O Projeto COL (Cursos on-line) 43

$\begin{array}{ll}2.4 .2 \text { A Plataforma Teleduc } & 44\end{array}$

2.4.3 O Projeto Tidia-AE $\quad 45$

2.4.4 O Projeto Amadeus $\quad 47$

2.5 Ambientes Virtuais de Aprendizagem: iniciativas internacionais 49

2.5.1 O Ambiente Virtual de Aprendizagem Moodle 49

2.5.2 O Ambiente Virtual de Aprendizagem Blackboard 50

2.5.3 O Ambiente Virtual de Aprendizagem EDX 51

2.5.4 O Ambiente Virtual de Aprendizagem Coursera 52

2.5.5 O Ambiente Virtual de Aprendizagem Edmodo 54

2.6 A Interação em Ambientes Virtuais de Aprendizagem 54

2.7 Significados e Sentidos em Ambientes Virtuais de Aprendizagem 58

3 Ambientes Virtuais de Aprendizagem e o ensino de Design 61

3.1 Ambientes Virtuais de Aprendizagem e a classificação Red Dot Design

3.2 Ambientes Virtuais de Aprendizagem e a classificação QS World University

3.3 Ambientes Virtuais de Aprendizagem mais utilizados internacionalmente

3.4 Análise e discussão dos Ambientes Virtuais de Aprendizagem mais usados internacionalmente

3.5 Considerações parciais dos Ambientes Virtuais de Aprendizagem

4 O designer instrucional e suas contribuições na construção de Ambientes Virtuais de Aprendizagem

4.1 Perfil e lugar do designer instrucional na construção de Ambientes Virtuais de Aprendizagem 
4.2 Ações concretizadas pelos designers instrucionais relacionadas à construção de Ambientes Virtuais de Aprendizagem, materiais impressos e recursos digitais educativos

4.2.1 Verificação se os designers instrucionais pesquisados trabalharam na construção de Ambientes Virtuais de Aprendizagem

4.2.2 Verificação de quais Ambientes Virtuais de Aprendizagem os designers pesquisados ainda não utilizaram ou que gostariam de utilizar

4.2.3 Verificação de qual é o melhor Ambiente Virtual de Aprendizagem na opinião dos pesquisados

4.2.4 Verificação acerca da apropriação de recursos em Três

Dimensões "3D" na produção de Ambientes Virtuais de Aprendizagem 90

4.2.5 Ambientes Virtuais de Aprendizagem utilizados pelos designers instrucionais pesquisados

4.2.6 Adequação dos Ambientes Virtuais de Aprendizagem que os designers instrucionais utilizam ou já utilizaram

4.2.7 Possibilidade de mudança de Ambientes Virtuais de Aprendizagem utilizados

4.2.8 Nível de alterações realizadas pelos designers instrucionais nos Ambientes Virtuais de Aprendizagem

4.3 As metodologias utilizadas nas produções de recursos (como produzem e quais ferramentas, técnicas ou teorias são utilizadas)

4.4 As possibilidades e perspectivas de ações e produções pelo profissional designer instrucional (melhorias da atuação, avaliação das ações e novos rumos)

4.4.1 Possibilidades de esquemas de comunicação em Ambientes Virtuais de Aprendizagem

4.4.2 Possibilidades na criação de Ambientes Virtuais de Aprendizagem

4.4.3 Critérios, métodos e técnicas a serem adotados na construção de Ambientes Virtuais de Aprendizagem

4.5 Considerações acerca das contribuições do design instrucional na construção de Ambientes Virtuais de Aprendizagem

107

5 Configurabilidade e multimodalidade em Ambientes Virtuais de Aprendizagem

5.1 A configurabilidade em Ambientes Virtuais de Aprendizagem

5.2 A multimodalidade em Ambientes Virtuais de Aprendizagem

5.3 Considerações parciais acerca da configurabilidade e da multimodalidade em Ambientes Virtuais de Aprendizagem

6 Concepções, significados e sentidos atribuídos aos Ambientes Virtuais de Aprendizagem

6.1 Procedimentos Metodológicos

6.2 Análise e interpretação dos dados 
6.2.1 A caracterização dos participantes 128

6.2.1.1 A utilização dos AVAs pelo grupo de Gestores 133

6.2.1.2 A utilização dos AVAs pelo grupo de educadores 138

6.2.1.3 A utilização dos AVAs pelo grupo de designers 143

6.2.1.4 Síntese da utilização dos AVAs 149

6.2.2 A avaliação dos Ambientes Virtuais de Aprendizagem nesta pesquisa

150

6.2.2.1 A avaliação dos AVAs pelo grupo de gestores 150

6.2.2.2 A avaliação dos AVAs pelo grupo de educadores 153

6.2.2.3 A avaliação dos AVAs pelo grupo de designers 158

6.2.2.4 Síntese da avaliação dos AVAs 161

6.2.3 A relação entre AVAs e o campo do Design 162

6.2.3.1 A relação entre AVAs e o campo do Design na visão dos gestores

162

6.2.3.2 A relação entre AVAs e o campo do Design na visão dos educadores

165

6.2.3.3 A relação entre AVAs e o campo do Design na visão dos designers

169

6.2.3.4 A síntese na relação entre AVAs e o campo do Design 173

6.3 Considerações parciais 173

7 Considerações finais 175

8 Referências bibliográficas 180

9 Apêndices 184 


\section{Lista de figuras}

Figura 1 - Gráfico setorial com nomes dos Ambientes Virtuais de Aprendizagem mais utilizados internacionalmente com quantitativo de usuários

Figura 2 - Exemplo de utilização do Sloodle

Figura 3 - Tela de configurações da página principal do ambiente Moodle

Figura 4 - Páginas iniciais do ambiente Blackboard

Figura 5 - Janela com as funcionalidades dos ambientes Moodle e Blackboard

Figura 6 - Página inicial do ambiente EDX com login de criador de curso

Figura 7 - Página inicial do ambiente Coursera com login de estudante

Figura 8 - Tela Principal do ambiente Edmodo

Figura 9 - Tela do recurso Fórum de Discussão no Moodle

Figura 10 - Tela do recurso Fórum no Blackboard

Figura 11 - Emojis disponíveis no Moodle e Blackboard

Figura 12 - Tela do recurso Discussão no EDX

Figura 13 - Tela do recurso Discussão no Coursera

Figura 14 - Tela Inicial do Edmodo

Figura 15 - Opções de ações no Edmodo 


\section{Lista de tabelas}

Tabela 1 - Análise de conteúdo dos questionários

Tabela 2 - Análise de conteúdo dos questionários

Tabela 3 - Gradação da relação entre ações realizadas pelos designers instrucionais e a prática característica do campo do Design

Tabela 1 - Relação de AVAs que os designers instrucionais gostariam de utilizar

Tabela 5 - O melhor Ambiente Virtual de Aprendizagem na opinião dos pesquisados

Tabela 6 - Ambiente Virtual de Aprendizagem produzido em Três Dimensões "3D"

Tabela 7 - Ambiente Virtual de Aprendizagem que os designers utilizam/utilizaram em sua atuação

Tabela 8 - Avaliação quanto à adequação do Ambiente Virtual de Aprendizagem que os designers instrucionais utilizam/utilizaram

Tabela 9 - Nível de alterações realizadas pelos designers instrucionais nos Ambientes Virtuais de Aprendizagem

Tabela 10 - Avaliação da adequação do Ambiente Virtual de Aprendizagem pelos tutores

Tabela 11 - Avaliação da adequação do Ambiente Virtual de Aprendizagem pelos educandos 


\section{Lista de quadros}

Quadro 1 - Quadro-síntese da pesquisa

Quadro 2 - Compilação da classificação hierárquica vertical descendente de instituições de ensino superior de Design

Quadro 3 - Instituições que oferecem cursos de Design a distância e seu respectivo Ambiente Virtual de Aprendizagem

Quadro 4 - Instituições no Red Dot Design (2014 a 2017) que oferecem cursos a distância fora da área do Design e seu respectivo Ambiente Virtual de Aprendizagem

Quadro 5 - Formação inicial e instituição de ensino dos pesquisados (Licenciatura)

Quadro 6 - Formação inicial e instituição de ensino dos pesquisados (Bacharelado)

Quadro 7 - Formação inicial e instituição de ensino dos pesquisados (Licenciatura e Bacharelado)

Quadro 8 - Formações acadêmicas dos participantes gestores, educadores e designers

Quadro 9 - Identificação dos AVAs que os pesquisados já utilizaram

Quadro 10 - Grau de familiaridade em relação ao uso das TDIC para a EaD 


\section{Lista de gráficos}

Gráfico 1 - Número de matrículas em cursos de graduação por modalidade de ensino no Brasil - 2006 a 2016

Gráfico 2 - Gráfico setorial baseado nos dados da pesquisa

Gráfico 3 - Gráfico setorial baseado nos dados da pesquisa

Gráfico 4 - Gráfico setorial baseado nos dados da pesquisa

Gráfico 5 - Faixa etária dos designers instrucionais

Gráfico 6 - Formação continuada dos pesquisados

Gráfico 7 - Formação continuada dos designers instrucionais pesquisados

Gráfico 8 - Construção de Ambientes Virtuais de Aprendizagem pelos designers instrucionais

Gráfico 9 - Esquemas de comunicação em recursos disponíveis aos educandos e tutores

Gráfico 10 - Níveis de interação em recursos digitais e/ou Ambientes Virtuais de Aprendizagem construídos pelos designers instrucionais 


\section{1 \\ Introdução}

As possibilidades de aproximação e interseção entre os campos do Design e Educação a Distância podem oportunizar reflexões teóricas acerca da abrangência de atuação do Design, assim como proporcionar a concretização de diferentes suportes físicos e digitais destinados às diferentes práticas de ensino-aprendizagem. Notamos, na atualidade, o surgimento de inúmeros esforços teóricos e práticos no diálogo interdisciplinar entre Design e Educação, com foco no aperfeiçoamento de modelos de interação e na configuração de novos recursos educativos.

$\mathrm{Na}$ atualidade, é possível encontrar diversas pesquisas, tais como os estudos promovidos por Portugal (2013) e Couto \& Oliveira (1999), dedicados a analisar as contribuições do campo do Design na elaboração de livros didáticos, jogos, softwares, entre outros suportes educativos. É oportuno reconhecer que na concepção de tais suportes é possível contar com a participação de designers, com o intuito de favorecer tais construções de forma interdisciplinar e colaborativa. Parte-se do pressuposto de que o Design pode contribuir para o aprimoramento de inúmeros objetos e serviços em diferentes segmentos da sociedade, entre esses no campo da Educação.

Nessa direção, consideramos a atuação do Design no âmbito projetual não apenas em melhorias estéticas e visuais, mas no planejamento de novas interfaces e interações. Consideramos que o designer não projeta apenas um objeto material, mas um conjunto de sistemas e interações. Assim, partimos da premissa de que o design é capaz de aprimorar os mais diversos recursos educativos, a partir da concepção de novas experiências entre usuário e objeto, sendo esse objeto um elemento físico ou digital.

Nesta pesquisa, buscamos direcionar a nossa análise, de modo particular, ao campo da Educação a Distância, e, de modo específico, no que se refere ao uso das Tecnologias Digitais da Informação e Comunicação (TDIC), e mais particularmente ainda, no âmbito da concepção e utilização de Ambientes Virtuais de Aprendizagem (AVA). 
O nosso interesse se direciona ao campo da Educação a Distância, por esta se caracterizar como uma modalidade de educação mediada por tecnologias analógicas e digitais, entre elas as TDIC, muito utilizadas nesse formato de ensino na atualidade. Uma das características dessa modalidade é que, em geral, os educandos e educadores não compartilham o tempo e o espaço quando utilizam ferramentas assíncronas. O que viabiliza essa condição flexível, nesse formato de ensino, são as características e funcionalidades oferecidas por tais tecnologias digitais.

Sendo assim, a confluência entre o Design e a Educação a Distância é capaz de contribuir para o surgimento de novos recursos educativos, viabilizando, deste modo, novas práticas de ensino.

Neste sentido, as motivações que despertaram as inquietações para a realização desta pesquisa deram-se a partir da possibilidade de interseção entre estes dois campos: Design e Educação a Distância. Alinhado à essa demanda está o nosso interesse em analisar a construção e configuração de materiais e recursos para a educação, destinados aos seus diferentes níveis e modalidades.

Ademais, somado a essas motivações, é possível também considerar o meu percurso profissional na realização de atividades de ensino, pesquisa e extensão, durante aproximadamente dez anos junto ao grupo de professores pesquisadores do Laboratório de Produção de Mídias "Espaço Poiesis" do Núcleo de Estudos e Pesquisas em Educação, Comunicação e Tecnologia (NECT), da Faculdade de Educação da Universidade do Estado de Minas Gerais (UEMG).

A trajetória que realizei no curso de bacharelado e no mestrado na Escola de Design da UEMG associada à experiência como docente no Curso de Pedagogia na mesma Universidade propiciaram um contato estreito com o discurso direcionado para o uso das Tecnologias Digitais da Informação e Comunicação na Educação. Assim como o percurso descrito, também favoreceu a aproximação com o universo de produção de mídias educativas, tanto para a modalidade presencial quanto para o ensino a distância.

Soma-se a esse percurso a nossa atuação em equipe no "Espaço Poiesis", que tornou possível nos últimos anos experimentar o planejamento e o desenvolvimento de animações, videoaulas e radioaulas, entre outros suportes midiáticos digitais para o ensino-aprendizagem em instituições de ensino. 
Já no ano de 2014, o meu ingresso no Curso de Doutorado em Design do Programa de Pós-Graduação em Design da PUC-Rio e a participação no Grupo de Pesquisa Design na Leitura de Sujeitos e Suportes em Interação (DeSSIn) do Laboratório Linguagem, Interação e Construção de Sentidos no Design (LINC) permitiram a realização de estudos acerca do Design e sua relação com as TDIC no âmbito da EaD. Tudo isso proporcionou a construção de uma concepção mais aprofundada sobre os fenômenos, abordagens e transformações na relação entre Design, TDIC e AVAs e suas prováveis implicações para a EaD.

A partir do contato com os educadores e pesquisadores nessas duas instituições, (UEMG e PUC-Rio), foi possível desenvolver o presente estudo com o intuito de verificar as aproximações e distanciamentos entre os campos do Design e da Educação a Distância, de modo a reconhecer as possibilidades e limitações que se apresentam em Ambientes Virtuais de Aprendizagem. Buscamos, dessa maneira, ao longo dos últimos anos, refletir sobre o crescente discurso acerca da incorporação das TDIC na educação, tanto nas modalidades de ensino presencial quanto no ensino a distância.

Reconhecemos, a partir dos estudos relacionados a essa temática, que no contexto atual existe a emergência do discurso pela incorporação das TDIC na educação, bem como o surgimento dos desafios para os educadores em lidar com tais recursos. É sabido que o advento das TDIC fez emergir inúmeras mudanças na sociedade a partir da segunda metade do século XX. Percebemos ainda na contemporaneidade que a incorporação de tais tecnologias ainda se apresenta com muito impacto, gerando, sobretudo, um grande desafio para muitos educadores.

Neste sentido, diante do advento das TDIC, notamos o surgimento de inúmeras transformações sociais, culturais e econômicas que tenderam a caracterizar novas formulações nos campos do Design, da Comunicação e da Educação. Essas mudanças têm se revelado como questões relevantes para uma postura crítica e reflexiva de se pensar novas propostas de formação de educandos e educadores, permitindo estabelecer um diálogo estreito acerca da construção de novos suportes e sistemas digitais educativos no contexto da formação humana.

Neste cenário contemporâneo, os impactos gerados pelas mudanças tecnológicas e culturais na sociedade tendem para a caracterização de um novo espaço, compreendido a partir da complexidade e do ritmo acelerado dessas transformações. Diante do atual modelo de globalização econômico e cultural 
estabelecido, das mutações advindas pelo progresso e do surgimento das TDIC, é possível reconhecer os impactos nas relações sociais que tenderam por também afetar diretamente os campos do Design e da Educação.

Nesta perspectiva, a presente pesquisa assume como TEMA as concepções e percepções dos agentes da $\mathrm{EaD}$ (gestores, designers, designers instrucionais, docentes, discentes etc.) acerca do que potencializa o AVA como suporte de significação e interação que media a relação educador-educando.

No intuito de se compreender as transformações contemporâneas, muitos estudiosos, tais como Giddens (1991), Lyotard (2002) e Castells (2009) afirmam que a sociedade atual vivencia um novo período marcado pelo surgimento de novos fenômenos e por mudanças gradativamente mais rápidas em várias dimensões, influenciando os modos de se comunicar, de se relacionar, de ensinar e de aprender. Assim, surgem diversas formulações na tentativa de compreender o cenário atual, em que predominam a complexidade, a dinamicidade e a descontinuidade nas relações entre os sujeitos na sociedade.

Neste particular, atualmente tem-se notado um discurso pela incorporação das tecnologias digitais da informação e comunicação com o objetivo de favorecer práticas educativas inovadoras, contextualizadas e atraentes a educandos e educadores, conforme sinaliza Moran (2007). O Design, por sua vez, tem sido capaz de oferecer métodos e estratégias capazes de contribuir na construção e aprimoramento de recursos educativos favoráveis às novas práticas educativas. No âmbito da Educação a Distância, tem sido possível notar a busca por estratégias de Design que promovam processos de comunicação e estruturação de meios compatíveis com um aprendizado de qualidade apropriando-se dos variados recursos digitais.

Considera-se, neste sentido, o Design como um processo multidisciplinar que assume características complexas, adequando-se a vários cenários em diferentes contextos. Assim, faz-se necessário compreender o Design como uma atividade projetual interdisciplinar e dinâmica, capaz de corresponder às transformações tecnológicas, à diversidade cultural, às possibilidades de construção de recursos educativos e à própria dinamicidade presente nesta sociedade.

O intento de se refletir sobre as questões que envolvem a relação entre Design e Educação a Distância também tem sido alvo de outras investigações que buscam compreender o universo da atuação do Design. Neste sentido, é possível destacar 
as contribuições de Filatro (2008), Behar (2009), Portugal (2013) e Couto \& Oliveira (1999), que enriquecem significativamente as discussões acerca da temática em análise dos fatores relacionados aos sistemas e processos de ensinoaprendizagem.

No âmbito da relação entre Design, Educação e Tecnologias Digitais de Informação e Comunicação, nota-se a possibilidade e a emergência de um movimento de convergência teórico-prático no que se refere à construção de materiais e recursos educativos digitais. Em geral, tais recursos são dedicados tanto à educação na modalidade a distância quanto à modalidade presencial. Em várias situações os recursos educativos são produzidos por educadores e não contam com a participação de designers. Também se encontram produções de tais recursos nos quais são formadas equipes que contam com designers, analistas e engenheiros e não dispõem da participação de educadores e educandos na sua elaboração e avaliação.

Diante desse cenário marcado pelos desencontros e pela demanda de aproximações entre educadores e designers, emerge a necessidade de se promoverem estudos voltados para as relações entre Design e Educação a Distância a partir do aprimoramento de Tecnologias Digitais de Informação e Comunicação com ênfase na construção e configuração de novos Ambientes Virtuais de Aprendizagem.

Considerando que nesta pesquisa o nosso foco está direcionado aos Ambientes Virtuais de Aprendizagem, é importante mencionarmos que, na atualidade, corriqueiramente encontramos diferentes conceitos que envolvem a definição de AVA. Encontramos na literatura da área e nos discursos no campo da EaD os seguintes termos: Ambientes Virtuais de Aprendizagem (AVA); Learning Management System (LMS - Sistema de Gestão da Aprendizagem), ou ainda o termo expresso na língua inglesa, Virtual Learning Environment (VLE - Ambientes Virtuais de Aprendizagem).

Entre os conceitos e formulações aqui apresentados, a presente pesquisa assume o termo Ambientes Virtuais de Aprendizagem (AVA) para se referir aos ambientes digitais nos quais se encontram inseridos e disponíveis diferentes Objetos Aprendizagem (AO), também denominados Objetos Interativos de Aprendizagem (OIA). Os OA se apresentam como vídeos, arquivos de áudio, 
textos, softwares, jogos digitais, entre outros recursos em interação com os usuários, destinando-se o seu uso em contextos de ensino-aprendizagem.

No que se refere à sua conceituação, ainda não há na atualidade um consenso acerca da sua definição. Em algumas situações, Objetos de Aprendizagem acabam sendo confundidos com o próprio Ambiente Virtual de Aprendizagem. Como exemplo disso, uma das definições mais utilizadas por estudiosos para descrever os OA é a formulação do Learning Technology Standards Committee (LTSC) do Institute of Electrical and Electronic Engineers (IEEE):

Objetos de Aprendizagem são definidos aqui como qualquer entidade, digital ou não digital, que podem ser usados, reutilizados ou referenciados durante a aprendizagem suportada por tecnologia. Exemplos de aprendizagem suportada por tecnologia incluem sistemas de treinamento baseado em computador, ambientes de aprendizagem interativos, sistemas de instrução inteligente auxiliada por computadores, sistemas de ensino a distância e ambientes de aprendizagem colaborativa. Exemplos de Objetos de Aprendizagem incluem conteúdo multimídia, conteúdos instrucionais, objetivos de aprendizagem, software instrucional e ferramentas de softwares, e personagens, organizações ou eventos referenciados durante aprendizagem suportada pela tecnologia. (IEEE, 2002, tradução nossa) ${ }^{1}$

No entanto, no campo de estudos da Educação a Distância encontra-se o termo Objeto de Aprendizagem sendo empregado predominantemente em um sentido específico, assumindo o título de "pedaços de conhecimento" autocontidos, conforme descreve Filatro (2008) referindo-se ao conceito. Para a autora, os Objetos de Aprendizagem são:

[...] identificados por descritores que trazem dados sobre autores, palavras-chave, assunto, versão, localização, regras de uso e propriedade intelectual, requisitos técnicos, tipo de mídia utilizada e nível de interatividade, entre outros. Esses descritores são chamados metadados (dados sobre dados) e permitem que sejam feitas buscas rápidas em repositórios de objetos. Seus elementos internos são organizados por meio de um mecanismo de empacotamento de conteúdo (do inglês, content packaging), que representa a estruturação dos conteúdos e o conjunto de regras para sequenciar a sua apresentação. (FILATRO, 2008, p.54)

\footnotetext{
${ }^{1}$ Texto original: Learning Objects are defined here as any entity, digital or non-digital, which can be used, re-used or referenced during technology supported learning. Examples of technology supported learning include computer-based training systems, interactive learning environments, intelligent computer-aided instruction systems, distance learning systems, and collaborative learning environments. Examples of Learning Objects include multimedia content, instructional content, learning objectives, instructional software and software tools, and persons, organizations, or events referenced during technology supported learning.

Fonte: http://grouper.ieee.org/groups/ltsc/wg12/
} 
Nessa direção, no Brasil, o Ministério da Educação (MEC) reconhece os Objetos de Aprendizagem como recursos educacionais, em diversos formatos e linguagens, que têm por objetivo mediar e qualificar o processo de ensinoaprendizagem (Brasil, 2015). Uma de suas principais características é a sua reusabilidade, que diz respeito à capacidade de reutilização desses materiais, em diferentes contextos de aprendizagem, nas mais diversas áreas do conhecimento.

Diante disso, o conceito de Ambiente Virtual de Aprendizagem pode assim ser compreendido a partir das contribuições de Salvador et al. (2017, p.7): "um ambiente virtual de aprendizagem reúne vários e diferentes tipos de objetos virtuais de aprendizagem em um contexto pedagógico comum".

Nesta pesquisa, busca-se considerar uma definição ampliada de Ambiente Virtual de Aprendizagem. Compreende-se de maneira ampla a ideia de ambiente em uma acepção relacionada ao conceito de "espaço" abordado por Milton Santos (2006). O "espaço" entendido como "um conjunto indissociável de sistemas de objetos e sistemas de ações" (Santos, 2006, p.12) em interação. Assim, entendemos o AVA como um ambiente no qual se consolida a interação entre sujeitos, objetos e conteúdos em situações de ensino-aprendizagem.

$\mathrm{Na}$ construção deste estudo, buscamos desvincular o conceito de Ambiente Virtual de Aprendizagem da ideia de "sala virtual", por acreditarmos que o espaço "sala" pode ser um conceito restritivo e limitar as possibilidades e estratégias para a promoção do ensino e da aprendizagem. Buscamos dissociar o AVA do conceito de sala, pois em algumas situações tendem a ser equivocadamente associados à ideia de um modelo de educação tradicional.

Nesta pesquisa buscaremos também reconhecer a configurabilidade em alguns Ambientes Virtuais de Aprendizagem. Assumimos como premissa que determinados AVAs apresentam menor ou maior grau de configuração em atendimento às demandas dos usuários. Existem características nos AVAs que os tornam mais suscetíveis à flexibilização e à adaptabilidade, proporcionando, assim, diferenças no planejamento, na preparação ou na adequação das propostas de ensino em atenção às necessidades de gestores, educadores e educandos. Consideramos que as funcionalidades (in)disponíveis em determinados ambientes virtuais de aprendizagem tendem a direcionar, restringir ou ampliar as possibilidades educativas. 
Nesta direção, esta pesquisa se disponibiliza tendo como foco a seguinte QUESTÃO NORTEADORA: quais as concepções dos agentes da Educação a Distância (gestores, designers, designers instrucionais, docentes, discentes, etc.) acerca do que potencializa o Ambiente Virtual de Aprendizagem como suporte de significação e interação que media a relação educador-educando?

De forma geral, a presente pesquisa presume quatro PRESSUPOSTOS relacionados à interseção entre Design e Educação a Distância: a) Cursos de Design utilizam AVAs projetados adequadamente com foco nas relações de ensinoaprendizagem; b) Instituições de Ensino Superior (IES) nacionais e internacionais que ofertam cursos de Design utilizam AVAs projetados adequadamente com foco nas relações de ensino-aprendizagem; c) Designers instrucionais qualificam AVAs quanto ao potencial de significação e interação nas situações de uso por comunidades de ensino-aprendizagem [polifonia]; d) Instituições de Ensino Superior com oferta de cursos de Design disponibilizam para a comunidade AVAs não configuráveis, enquanto os Designers Instrucionais qualificam AVAs configuráveis como melhores para atender às demandas da comunidade.

A partir da emergência de tais reflexões voltadas para a relação entre Design e Educação a Distância e de se aprofundar acerca das interações em Ambientes Virtuais de Aprendizagem, o presente estudo tem como OBJETIVO GERAL: compreender as concepções dos agentes da $\mathrm{EaD}$ (gestores, docentes e designers) acerca do que potencializa o AVA como suporte de significação e interação que media a relação educador-educando.

Considera-se nesse processo de busca, por entender as concepções e percepções de agentes da $\mathrm{EaD}$, uma perspectiva em que possam ser evidenciadas as possibilidades de adequação de AVAs e a respectiva contextualização e significação desse suporte em situações de uso.

Destaca-se que, através de um estudo exploratório, diversos aspectos relevantes poderão ser revelados a partir da análise das concepções dos agentes da $\mathrm{EaD}$ acerca do que potencializa o AVA como suporte de significação e interação e também mediador da relação educador-educando.

Para se alcançar o intento desta investigação, percorremos cinco OBJETIVOS ESPECÍFICOS: a) identificar e analisar AVAs utilizados nos cursos de Design em instituições nacionais e internacionais; b) identificar e analisar 


\section{AVAs utilizados em instituições de ensino superior nacionais e internacionais} que ofertam cursos de Design; c) sintetizar as concepções de designers instrucionais, com vistas a tratar o potencial de significação e interação de AVAs; d) apresentar uma sistematização das possibilidades e características de (configuração e não configuração) em AVAs; e) identificar e entender as concepções, significados e sentidos atribuídos por gestores, educadores e designers aos Ambientes Virtuais de Aprendizagem.

No percurso desta pesquisa, partimos do entendimento de que na contemporaneidade as Tecnologias Digitais de Informação e Comunicação têm sido reconhecidas como recursos com um potencial significativo em processos educacionais que facilitam a interação entre educandos, educadores e conteúdos em situações de ensino-aprendizagem. Tem-se discutido sobre o potencial de uso dessas tecnologias e suas aplicações na educação. Nesse debate, notam-se inúmeras proposições e reflexões que tendem a questionar como tais recursos tecnológicos podem contribuir para uma renovação dos métodos tradicionais de produção de conhecimento, em que várias possibilidades de mediação e interação são oferecidas pelos meios informatizados, que disponibilizam uma flexibilidade de apropriação, além da diversidade de recursos disponíveis para uso de educadores e educandos.

A partir dessa realidade, a introdução dos recursos digitais e do computador na educação tem se mostrado como um desafio tanto para os educadores e gestores em instituições de ensino quanto para os profissionais e técnicos que desenvolvem materiais e recursos interativos de aprendizagem. Moran (2007) observa que a internet, os dispositivos digitais móveis e as TDIC, de forma geral, estão revolucionando o cotidiano das pessoas e fazendo emergir novas soluções para os problemas diários da vida, numa perspectiva de mudança e ampliação das possibilidades de fazer pesquisas, comunicar, aprender, comprar produtos e serviços, entre outros.

De acordo com Moran (2007, p.9), "Nossa vida interligará cada vez mais as situações reais e as digitais, os serviços físicos e os conectados, o contato físico e o virtual, a aprendizagem presencial e a virtual”. E essa perspectiva compreende a realidade humana de maneira interligada e integrada. "O mundo físico e o virtual não se opõem, mas se complementam, integram, combinam numa interação cada vez maior, contínua, inseparável”. (Ibid.) 
Sendo assim, buscamos por meio desta pesquisa uma abordagem que vise entender as concepções dos agentes da $\mathrm{EaD}$ acerca do que potencializa o AVA como suporte de significação e interação. Examinando os elementos tecnológicos existentes, tem-se a proposta de evidenciar as variáveis possíveis de serem reconhecidas e questionadas. Pretende-se promover uma análise a partir do cruzamento de informações encontradas, objetivando observar as similaridades, convergências e variáveis entre projetos, produções e concepções.

Com o intuito de contemplar os objetivos propostos, definiu-se como PROCESSO METODOLÓGICO a realização de uma pesquisa do tipo qualitativa, com características de um estudo exploratório. O percurso metodológico utilizado compreende um estudo exploratório constituído de cinco etapas:

1) inicialmente, em uma primeira etapa, realizamos uma reflexão teórica acerca dos conceitos previstos na condução da pesquisa, além de uma análise sobre as possibilidades de aproximação e interseção entre os campos da Educação a Distância e Design;

2) posteriormente, promovemos uma análise do panorama de processos de concepção, apropriação e utilização de AVAs a partir do ranking de instituições;

3) na terceira etapa, realizamos um estudo por meio da aplicação de questionários destinados a designers instrucionais, para compreender o potencial de significação e interação nas situações de uso por comunidades de ensino-aprendizagem [polifonia];

4) a quarta etapa contemplou a análise de alguns ambientes virtuais de aprendizagem com o intuito de classificá-los e categorizá-los pelo viés da configurabilidade e multimodalidade;

5) finalmente, na quinta etapa, realizamos entrevistas junto aos agentes da $\mathrm{EaD}$ (gestores, designers, designers instrucionais, docentes, discentes etc.), com o intuito de avaliar o uso dos AVAs pelos designers e pelas comunidades. 
Para esse intento, assumimos neste estudo a pesquisa do tipo qualitativa, com o objetivo de se compreender o objeto investigado e considerar aspectos de flexibilidade e pluralidade que as investigações dessa natureza apresentam. Devese ressaltar que esse tipo de pesquisa auxilia na compreensão de questões relevantes e possibilita o entendimento de fenômenos em situações diversas a partir das respostas encontradas. Ao invés de utilizar números, fazem uso da textualidade como material empírico.

Conforme sinaliza Flick (2009, p. 16):

A pesquisa qualitativa usa o texto como material empírico (em vez de números), parte da noção da construção social das realidades em estudo, está interessada nas perspectivas dos participantes, em suas práticas do dia a dia e em seu conhecimento cotidiano relativo à questão em estudo.

Dessa forma, os métodos utilizados precisam ser adequados a determinada questão, devendo ser abertos o suficiente para possibilitar o entendimento das relações.

A RELEVÂNCIA desta pesquisa está na perspectiva de que, diante do cenário de desenvolvimento de Tecnologias Digitais de Informação e Comunicação e da emergência em ampliar o índice de pessoas com nível superior, nota-se que a $\mathrm{EaD}$ tem se mostrado como uma alternativa de democratização do acesso à educação para aqueles educandos dispersos geograficamente. Além disso, têm-se percebido na atualidade as potencialidades dos diferentes recursos digitais no que se refere à apropriação de múltiplas linguagens e em diversificar as estratégias de interação entre educandos, educadores e os materiais didáticos. Nota-se, assim, a necessidade de ações interdisciplinares envolvendo o Design e a Educação a Distância com foco na compreensão das potencialidades dos AVAs.

Nessa direção, considerando as potencialidades do design como atividade interdisciplinar, é possível reconhecer a sua adaptabilidade diante dos variados cenários que surgem em diferentes épocas. É preciso compreender o Design como uma prática capaz de corresponder à diversidade, ao multiculturalismo, às possibilidades de construção de valores e processos, considerando, entre outros, a produção de suportes e sistemas de caráter educativos.

Dessa forma, o reconhecimento do conceito de Design e seu significado para a sociedade precisam estar associados às suas práticas em seu respectivo contexto. Ao contrário de apenas se constituírem esforços em delimitar seu campo de atuação, 
é necessário ir além da mera distinção do que seja ou não Design, para que, dessa maneira, seja possível uma ampliação de horizontes. Nesse sentido, surgem formulações que apontam o Design como uma estratégia em potencial na elaboração de materiais educativos, suportes e sistemas, destinados a situações de ensino-aprendizagem.

Diante disso, também reconhecemos que, embora a construção de novos recursos educativos possa favorecer novas práticas educativas, é também necessário reconhecer que se torna indispensável o surgimento de ações e práticas inovadoras por parte dos educadores, no uso de tais recursos, conforme sinalizam Oliveira et al. (2001) referindo-se aos softwares educativos:

[...] é importante se esclarecer que, mesmo que a equipe produtora de Software Educativo tenha tido todo um grande empenho em imprimir a um programa uma base interacionista, isto não o torna necessariamente construtivista. A sua utilização é que, em muitos casos, garantirá a coerência necessária entre a sua concepção e a prática pedagógica na qual se encontra inserido. Daí a importância de o software ser acompanhado por um manual de orientação ao professor. Ressalta-se por outro lado a possibilidade de uma sequência adequada de telas e procedimentos orientadores do uso de um SE virem a influenciar significativamente a prática pedagógica do professor. (Oliveira et al., 2001, p.35-36)

Nessa direção, Behar et al. (2009) também defendem que os impactos produzidos pelas transformações geradas pelas TDIC promovem mudanças expressivas também no universo das práticas pedagógicas. Como exemplo disso, citam-se os impactos gerados pelo crescimento da produção de Objetos de Aprendizagem como também de Ambientes Virtuais de Aprendizagem, que têm exigido cada vez mais uma adaptação por parte dos educadores no que diz respeito a sua atuação.

Considera-se que a utilização dos Objetos de Aprendizagem e dos Ambientes Virtuais de Aprendizagem contribui para o surgimento de uma nova proposta de aprendizagem apoiada pelas TDICs, na qual os educadores tendem a abandonar as ações de transmissor de informação para desempenhar uma ação de mediador da aprendizagem. E assim, para Behar et al. (Ibid, p. 66), gradativamente vêm sendo desenvolvidos novos recursos didáticos para uso nos computadores, dispositivos digitais, e são disponibilizados para serem incorporados "ao processo de aprendizagem, adaptando-os às diferentes necessidades, tais como de público, conteúdo, tempo e prática pedagógica”. 
Portanto, evidencia-se de forma cada vez mais clara que a elaboração e configuração de suportes e processos no âmbito da educação, comunicação e tecnologia têm sido uma das demandas em crescimento nestes últimos anos. O fato de as TDIC se fazerem cada vez mais presentes nos diversos setores da sociedade, inclusive no campo educacional, faz com que elas se tornem uma condição sine qua non para cursos de formação de educadores, tanto no âmbito da formação inicial quanto nos programas de formação continuada.

Todavia, a utilização das TDIC na educação demanda um esforço permanente dos educadores para transformar o simples uso dos computadores em uma proposta de abordagem educacional. A interação com os recursos digitais necessita favorecer o processo de construção de conhecimento dos educandos, conforme sinalizam Oliveira et al. (2001, p.32). Assim, a interação com os objetos da aprendizagem e os mais diversos artefatos digitais contribui para o desenvolvimento do pensamento hipotético dedutivo dos educandos e fortalece "sua capacidade de interpretação e análise da realidade tornam-se privilegiados e a emergência de novas estratégias cognitivas do sujeito é viabilizada".

Nesse sentido, temos percebido que as principais características e potencialidades dos recursos educativos bem como as ações dos educadores podem destacar a participação ativa dos educandos com a possibilidade de despertar a curiosidade, a atenção e favorecer a interação. Moran (2007, p.167) ressalta que a educação precisa: “encantar, entusiasmar, seduzir, apontar possibilidades e realizar novos conhecimentos e práticas". Além disso, Moran (Ibid, p.167) afirma que "o conhecimento se constrói com base em constantes desafios, atividades significativas que excitem a curiosidade, a imaginação e a criatividade”.

Moran (2007) acredita que existam três campos importantes para as atividades virtuais: “o da pesquisa, o da comunicação e o da produção.” Na pesquisa individual, a preocupação é com os temas, as experiências e os projetos. Em comunicação, busca-se o debate sobre esses temas, na forma off-line ou online. A produção preocupa-se em divulgar os resultados em formatos de hipertexto, multimídia etc., para que os resultados sejam disponibilizados para colegas e, ocasionalmente, para comunidades externas ao curso. Moran (2007) destaca a importância da aprendizagem centrada no educando: 
Se os alunos fizessem pontes entre o que aprendem intelectualmente e as situações reais, experimentais, profissionais ligadas aos seus estudos, a aprendizagem seria mais significativa, viva e enriquecedora. As universidades e os professores precisam organizar atividades integradoras na prática com a teoria, do compreender com o vivenciar, do fazer e do refletir, de forma sistemática, presencial e virtualmente, em todas as áreas e ao longo do curso. (Moran, 2007, p.100)

[...] com o avanço da banda larga na internet, com a TV digital e outras tecnologias móveis, teremos todas as possibilidades de cursos: dos totalmente prontos e oferecidos através de mídias audiovisuais até os construídos ao vivo, com forte interação grupal e pouca previsibilidade. Teremos cursos totalmente on-line e outros parcialmente on-line. Só não teremos os modelos atuais convencionais. (Ibid., p.11)

Neste particular, é necessário reconhecer que uma escola ativa necessita ter como focos pesquisa, projetos, experimentação, criação, “[...]. Não depende só de alta tecnologia, mas de pessoas criativas e de projetos pedagógicos institucionais bem gerenciados. [...]”. (Ibid., p.155)

Filatro (2004) afirma que educação para a vida passa a ser uma exigência permanente para a sociedade, direcionando a uma compreensão da escola e da universidade como conceito e não como lócus. [...] "A educação tradicional vê aflorar novas formas de pensar, de construir e de comunicar com o conhecimento, as quais lançam importantes questionamentos quanto a seus objetivos, práticas e resultados" (Filatro, 2004, p. 36). A autora ainda complementa que é necessário compreender alguns elementos básicos das TDIC, não apenas de forma técnica, mas os significados para as atividades humanas. É nesse sentido que as tecnologias digitais da informação e comunicação podem ser incorporadas no cotidiano das instituições educacionais e de todos os envolvidos com a educação e a cidadania.

Sendo assim, nesta pesquisa, percebemos que as interseções entre os campos da Educação e do Design poderão contribuir para se repensar a construção, configuração e oferta de Ambientes Virtuais de Aprendizagem que possam favorecer processos de interação entre sujeitos, objetos e conteúdos em situações de ensino-aprendizagem.

Assim, a estrutura desta pesquisa está composta de sete capítulos, conforme segue:

No primeiro capítulo - Introdução - são apresentados os motivos e objetivos que sustentam a realização desta pesquisa e também é feito um preâmbulo do contexto de utilização de Ambientes Virtuais de Aprendizagem com as formulações e tentativas de elucidar a temática. 
No segundo capítulo - Aspectos conceituais da pesquisa e as relações possíveis entre Educação a Distância e o Design - são discutidos aspectos da Educação a Distância e do Design, sendo observadas algumas especificidades que se referem aos conceitos de interação, significação e sentidos no contexto dos Ambientes Virtuais de Aprendizagem.

No terceiro capítulo - Ambientes Virtuais de Aprendizagem e o Ensino de Design - são feitos um levantamento e a análise de AVAs utilizados nos Cursos de Design em instituições nacionais e internacionais. Também são expostos e analisados os AVAs utilizados em instituições de ensino superior, nacionais e internacionais que ofertam, entre outros cursos, o de Design.

No quarto capítulo - $\mathrm{O}$ designer instrucional e suas contribuições na construção de Ambientes Virtuais de Aprendizagem - apresenta-se uma síntese das concepções de designers instrucionais, com vistas a tratar o potencial de interação, significação e sentidos em AVAs.

No quinto capítulo - Configurabilidade e multimodalidade em Ambientes Virtuais de Aprendizagem - analisam-se alguns Ambientes Virtuais de Aprendizagem com o intuito de classificá-los e categorizá-los pelo viés da configurabilidade e multimodalidade.

No sexto capítulo - Concepções, significados e sentidos atribuídos aos Ambientes Virtuais de Aprendizagem - apresentam-se os resultados de uma experimentação realizada no formato de simulação de uso por nove usuários, feita em três Ambientes Virtuais de Aprendizagem diferentes.

Em Considerações Finais, será possível analisar, discutir a síntese ou a antítese dos resultados da pesquisa, revelando como as instituições e agentes reconhecem, estruturam as aulas e quais os ganhos possíveis de serem alcançados por meio desse estudo.

Em Referências são nomeadas as obras e autores utilizados na sustentação desta pesquisa.

Nos Apêndices encontram-se os termos de Consentimento enviados aos pesquisados assim como os questionários aplicados.

O quadro-resumo (Quadro 1) a seguir explicita os itens desta pesquisa. 


\begin{tabular}{|c|c|}
\hline$\frac{0}{\frac{0}{0}} \frac{0}{0}$ & $\begin{array}{l}\text { As concepções e percepções dos agentes da Educação a Distância (gestores, } \\
\text { designers, designers instrucionais, docentes, discentes etc.) acerca do Ambiente } \\
\text { Virtual de Aprendizagem. }\end{array}$ \\
\hline 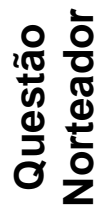 & $\begin{array}{l}\text { Quais as concepções dos agentes da Educação a Distância (gestores, } \\
\text { designers, designers instrucionais, docentes, discentes, etc.) acerca do que } \\
\text { potencializa o AVA como suporte de significação e interação que media a relação } \\
\text { educador-educando? }\end{array}$ \\
\hline 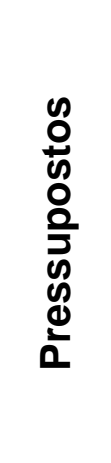 & $\begin{array}{l}\text { a) Cursos de Design utilizam AVAs projetados adequadamente com foco nas } \\
\text { relações de ensino-aprendizagem. } \\
\text { b) IES nacionais e internacionais que ofertam cursos de Design utilizam AVAs } \\
\text { projetados adequadamente com foco nas relações de ensino-aprendizagem. } \\
\text { c) Designers instrucionais qualificam AVAs quanto ao potencial de significação e } \\
\text { interação nas situações de uso por comunidades de ensino-aprendizagem } \\
\text { [polifonia]. } \\
\text { d) Instituições de Ensino Superior com oferta de cursos de Design disponibilizam } \\
\text { para a comunidade AVAs não configuráveis, enquanto os designers instrucionais } \\
\text { qualificam AVAs configuráveis como melhores para atender às demandas da } \\
\text { comunidade. }\end{array}$ \\
\hline 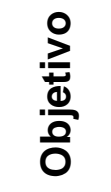 & $\begin{array}{l}\text { Compreender as concepções dos agentes da EaD (gestores, designers, } \\
\text { designers instrucionais, docentes, discentes etc.) acerca do que potencializa o } \\
\text { AVA como suporte de significação e interação que media a relação educador- } \\
\text { educando. }\end{array}$ \\
\hline $\begin{array}{l}\frac{\pi}{8} \\
\frac{0}{0} \\
\frac{0}{0} \\
\frac{0}{0} \\
\sum\end{array}$ & $\begin{array}{l}\text { (Etapa 01) - Inicialmente, numa primeira etapa, realizamos uma reflexão teórica } \\
\text { acerca dos conceitos previstos na condução da pesquisa, além de uma análise } \\
\text { sobre as possibilidades de aproximação e interseção entre os campos da } \\
\text { Educação a Distância e do Design. } \\
\text { (Etapa 02) - Posteriormente, fizemos uma análise do panorama de processos } \\
\text { de concepção, apropriação e utilização de AVAs partir do ranking de instituições. } \\
\text { (Etapa 03) - Numa terceira etapa realizamos um estudo por meio da aplicação } \\
\text { de questionários destinados a designers instrucionais, para compreender o } \\
\text { potencial de significação e interação nas situações de uso por comunidades de } \\
\text { ensino-aprendizagem [polifonia]. } \\
\text { (Etapa 04) - Numa quarta etapa realizamos uma análise em alguns Ambientes } \\
\text { Virtuais de Aprendizagem com o intuito de classificá-los e categorizá-los pelo } \\
\text { viés da configurabilidade e multimodalidade. } \\
\text { (Etapa 05) - Finalmente, na quinta etapa, entrevistas junto aos agentes da EaD } \\
\text { (gestores, designers, designers instrucionais, docentes, discentes, etc.) com o } \\
\text { intuito de avaliar o uso dos AVAs pelos designers e pelas comunidades. }\end{array}$ \\
\hline
\end{tabular}

Quadro 1 - Quadro-síntese da pesquisa

Fonte: Elaborado pelo autor.

Assim, esta pesquisa se dedica a conhecer as interseções possíveis entre os campos do Design e da Educação a Distância e verificar as oportunidades interdisciplinares na construção e configuração de Ambientes Virtuais de Aprendizagem. Este capítulo teve como objetivo apresentar as motivações que 
despertaram as inquietações assim como o intento de se desenvolver a presente pesquisa. Apresentaram-se de modo preliminar os argumentos e as contribuições que sustentam e justificam a demanda por estudos dedicados à relação entre Design e Educação a Distância. Além, disso, teve-se como intento explicitar sumariamente o contexto e as etapas metodológicas desta pesquisa. 


\section{2 \\ Aspectos conceituais da pesquisa e as relações possíveis entre Educação a Distância e Design}

Neste capítulo tem-se como proposta fazer uma reflexão acerca dos conceitos previstos na condução desta pesquisa e discorrer sobre as possibilidades de interseção entre os campos da Educação a Distância e Design. O foco é demonstrar, através de uma breve análise, as características do campo da Educação a Distância, assim como do Design, com vistas a tratar as particularidades dos Ambientes Virtuais de Aprendizagem. Sequencialmente, serão tratadas, também neste capítulo, algumas especificidades que se referem aos conceitos de interação, significados e sentidos no contexto dos Ambientes Virtuais de Aprendizagem.

\section{1}

\section{Aspectos conceituais da Educação a Distância}

No âmbito da Educação a Distância, sabe-se que o seu percurso histórico não se inicia em um período muito recente. Para muitos, essa modalidade de educação tem mais de 150 anos, sendo reconhecida sua significativa relevância a partir de meados do século XIX, quando emergem inúmeros cursos ofertados por meio de correspondência postal para o treinamento vocacional. A sua valorização e seu reconhecimento na esfera pública ocorreram na segunda metade do século XX, com a institucionalização de universidades dedicadas a essa modalidade, de modo especial, citam-se as ações da "The Open University", sediada na Inglaterra.

Conforme sinaliza Corrêa (2007), a Educação a Distância possui uma longa tradição, e é possível o seu agrupamento de acordo com os artefatos tecnológicos utilizados nessa modalidade. Numa primeira geração, temos o uso do material impresso para a comunicação com os educandos e o desenvolvimento dos conteúdos. Numa segunda geração, utilizaram-se materiais de áudio e vídeos,

\footnotetext{
${ }^{2}$ The Open University é uma instituição fundada em 1969, dedicada ao Ensino a Distância, com uma política aberta de admissão. Atualmente, mais de 180 mil estudantes interagem com a Universidade de forma on-line.
} 
vinculados ao uso de televisores e fitas VHS (Vídeo Home System). E uma terceira geração constituída pelo uso das TDIC, o que viabilizou uma maior flexibilização dos processos informacionais e comunicativos.

Para uma análise sobre as características da Educação a Distância, é necessário considerar que essa modalidade emergiu como uma alternativa possível de formação inicial e continuada, especialmente no cenário de países de economia em desenvolvimento. Em alguns desses países, caracterizados particularmente pela dificuldade de acesso ao ensino formal, predominavam altas taxas de defasagem de escolarização e de analfabetismo, as quais se revelaram num contexto em que educandos-trabalhadores precisavam assumir uma elevada jornada de trabalho, inviabilizando o investimento em educação regular e continuada.

A Educação a Distância surge e se estabelece mundialmente com o intento de promover um processo de democratização da educação a um público que se encontra distante dos grandes centros de formação. Nesse cenário, observa-se que a EaD surge como uma iniciativa de promover o acesso à educação e contrapor a lógica da centralização do conhecimento formal em espaços acadêmicos situados em metrópoles.

Atualmente, observa-se que a Educação a Distância enfrenta, além desses desafios, agora outros de natureza cultural e social. Nos dizeres de Corrêa (2007, p.10), “[...] várias outras distâncias nos afastam em virtude das diferenças culturais, sociais e afetivas, ou, então, distâncias enormes são forjadas pelas desigualdades econômicas, sociais e afetivas". Tais desafios são notados diante das dinâmicas de exclusão e de dispersão geográfica dos sujeitos maquinadas pelo sistema socioeconômico.

Diante dos processos de promoção do acesso à educação, a EaD também se revela com características típicas e específicas no sentido de conferir aos educandos certa flexibilidade e autonomia para compatibilizar o horário e espaço de estudo. Além disso, essa modalidade tem como característica fundamental a adaptação aos educandos e a suas necessidades bem como ao seu ritmo de aprendizagem e suas preferências.

Neste particular, é possível reconhecer que a Educação a Distância é capaz de viabilizar a democratização do acesso à educação, assim como permitir a autonomia dos educandos na gestão do tempo. O que amplifica essa autonomia para os 
educandos se concretiza a partir da utilização e apropriação das Tecnologias Digitais de Informação e Comunicação em propostas de ensino nessa modalidade.

A exemplo disso, temos que, a partir do advento do computador portátil e do surgimento de outros artefatos digitais, tais como smartphones e tablets com acesso à internet móvel, é possível pensar não só na autonomia discente quanto também na flexibilidade do acesso ao AVA. Assim, temos na Educação a Distância a possibilidade de permitir ao estudante gerenciar seu ritmo, seu tempo, num processo de independência. No entanto, essa autonomia na EaD também pede um comportamento proativo, com autodisciplina, na busca por ser ainda mais responsável pelo seu aprendizado.

O surgimento e a incorporação das TDIC na Educação a Distância permitiram não apenas uma maior autonomia e flexibilização aos educandos nos modos de estudar e aprender. As TDIC viabilizaram o desenvolvimento de AVA e propiciaram uma nova maneira de os educandos se relacionarem com os mais diferentes conteúdos, experimentando uma aprendizagem colaborativa, constituída pelas trocas de informações com seus colegas e pela construção de conhecimento em rede.

Consideramos, assim, que diferentes estratégias e recursos necessitam ser planejados e disponibilizados em processos de elaboração e oferta de cursos na modalidade a distância. Deste modo, reconhecemos a importância da elaboração e configuração dos Ambientes Virtuais de Aprendizagem em sintonia com os anseios e necessidades de educandos e educadores. É possível pensar que o planejamento e o desenvolvimento de AVA poderão propiciar a convergência de uso de diferentes recursos num processo de complementação de um com o outro, fazendo uso da associação entre textos, imagens, áudios e vídeos como estratégia focada na constante melhoria da aprendizagem.

Sendo assim, é válido considerar que o planejamento dos cursos na modalidade a distância demandará ações que envolvem o alinhamento entre estratégias diferenciadas e aprimoradas por parte dos educadores, mas também a disponibilidade de um ambiente adequadamente planejado. Tudo isso sendo conduzido com processos contínuos de avaliação, com a finalidade de acompanhar e verificar se os processos e recursos de ensino disponíveis estão adequados e alinhados às necessidades de aprendizagem dos educandos. 
Neste sentido, considera-se que ainda há muito o que avançar em pesquisas no campo da Educação a Distância, enfatizando o reconhecimento de suas potencialidades, limitações, certezas e incertezas, a fim de aprimorar suas ações de flexibilização e democratização do acesso à educação. Conforme Corrêa (2007, p.10). "De um modo geral encontram-se publicações e literaturas sobre EaD que descrevem seu histórico, vantagens e desvantagens". É necessário, no entanto, avançar na descrição das práticas pedagógicas em Educação a Distância e nas análises qualitativas das experiências. Para tanto, é necessário garantir que a Educação a Distância se torne cada vez mais presente nas universidades e em instituições de pesquisa, para que se desenvolvam estudos avançados, pesquisas e projetos não só para a criação de estratégias favoráveis a essa modalidade, mas de maturação de suas potencialidades de democratização do acesso à educação.

Nesse percurso de valorização da Educação a Distância, é preciso aperfeiçoar as estratégias e os recursos de forma a ampliar seus espaços de promoção do ensino, com equidade e qualidade. Diante disso, a Educação a Distância pode ser uma possibilidade de ensino que favoreça a diminuição de desigualdades e o aumento de oportunidades para muitos cidadãos dispersos geograficamente, tanto no Brasil assim como em outros países.

De modo particular, é válido salientar que no cenário brasileiro, de acordo com o Instituto Nacional de Estudos e Pesquisas Educacionais Anísio Teixeira (INEP/MEC), o número de cursos de graduação na modalidade a distância, entre os anos de 2003 a 2006, passou de 52 para 349, o que significou um aumento de $571 \%$. Já entre os anos de 2006 a 2016, o número de cursos ofertados totalizou 1.662, correspondendo a um aumento de $376 \%$. Ainda segundo o censo da educação superior, realizado por esse Instituto, no ano de 2016, foram registrados mais de 1,4 milhão de alunos estudando em cursos a distância (INEP, 2016). Esse fato demonstra uma conquista expressiva de espaço e de adesão à Educação a Distância no cenário brasileiro.

No Gráfico 1 é possível notar o crescimento do número de educandos matriculados na modalidade a distância entre os anos de 2006 a 2016: 


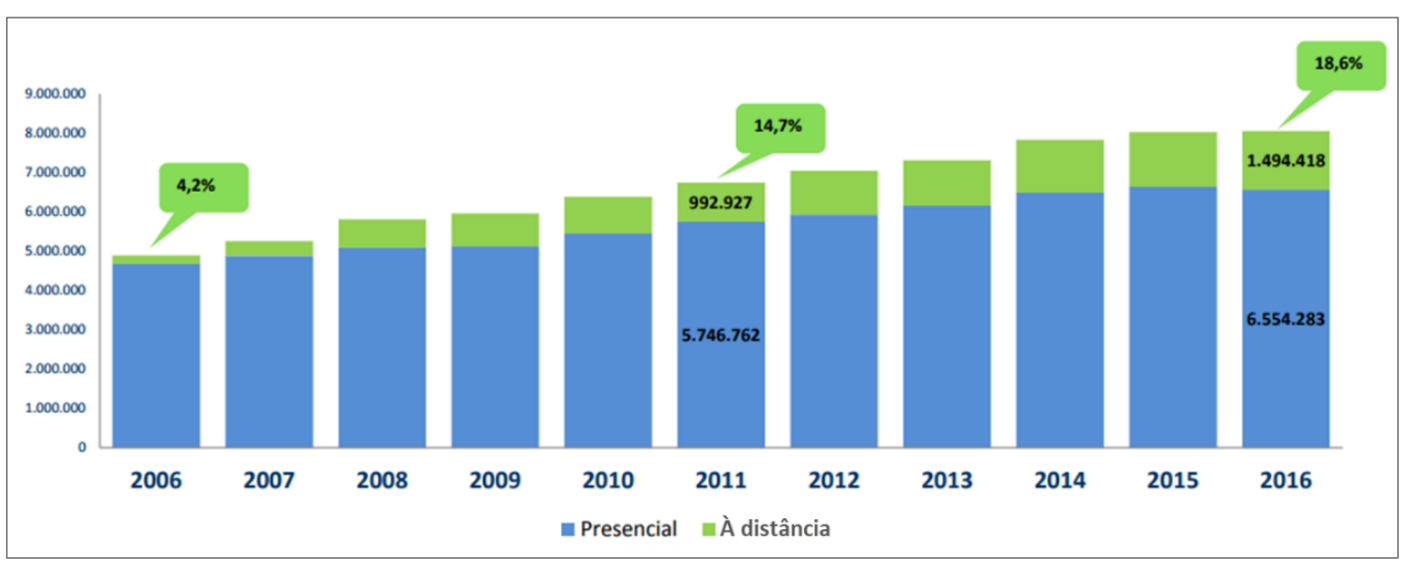

Gráfico 1 - Número de matrículas em cursos de graduação por modalidade de ensino no Brasil - 2006 a 2016

Fonte: INEP (2016).

Diante desse crescimento exponencial de cursos na modalidade a distância, consideramos ter havido também um aumento na demanda de construção e configuração de Ambientes Virtuais de Aprendizagem destinados aos mais variados cursos. Assim, um questionamento que tende a emergir diante desse panorama é: será que tem havido uma preocupação, por parte das instituições de ensino, acerca da disponibilidade e adequação de ambientes aos diferentes perfis de usuários? Essa e outras perguntas acabam por emergir em nosso imaginário, num contexto marcado pela crescente adesão a esse formato de ensino.

\section{2 Aspectos conceituais do Design}

Nesta subseção, buscaremos elucidar brevemente os aspectos conceituais do Design. O nosso intento é favorecer o entendimento desse campo àquele leitor que não possui ainda familiaridade com o tema. Relembramos que esta pesquisa tem como um de seus propósitos analisar as interseções possíveis entre Design e Educação a Distância. Eventualmente, diferentes leitores poderão se interessar sobre o estudo que ora se apresenta. Aos leitores que se interessarem por uma leitura mais detalhada sobre o conceito do Design, sugerimos literaturas específicas da área, tais como Cardoso (2004), Forty (2013) e John Heskett (2008). São inúmeras as publicações que discorrem de modo aprofundo sobre aspectos teóricos, históricos e conceituais do Design.

No entendimento do conceito de Design, o termo deriva da palavra em latim designare, sendo adaptado para o inglês “design”, e significa criação, idealização, 
configuração. O conceito de Design tem tido, ao longo dos anos, uma trajetória caracterizada por diferentes influências e concepções que contribuíram para a consolidação de sua definição. Assim, algumas formulações alinhadas à valorização da industrialização o relacionam apenas às atividades de concepção de objetos a serem fabricados em série pela indústria. Embora esse entendimento se aplique em suas práticas e tenha permanecido por um longo período, considera-se essa conceituação incompleta bem como saturada de algumas imprecisões.

Numa análise das variadas contribuições para a definição do conceito atual de Design, é possível observar que ele não se apresenta apenas na produção seriada de artefatos industriais, mas como um processo interdisciplinar de projetar produtos e serviços, configurando objetos industriais e artesanais, artefatos físicos e digitais.

O International Council of Societies of Industrial Design (ICSID), que passou a adotar oficialmente, a partir de 2017, o nome World Design Organization (WDO), votou em sua vigésima nona edição da assembleia geral, promovida entre os dias 17 e 23 de outubro de 2015, em Gwangju, na Coreia do Sul, uma definição renovada do conceito de Design, como sendo:

O Design Industrial é um processo estratégico de resolução de problemas que impulsiona a inovação, constrói o sucesso do negócio e leva a uma melhor qualidade de vida através de produtos, sistemas, serviços e experiências inovadores. Design Industrial estabelece uma ponte entre o que é e o que é possível. É uma profissão transdisciplinar que aproveita a criatividade para resolver problemas e cocriar soluções com a intenção de tornar um produto, sistema, serviço, experiência ou um negócio, melhor. Em seu coração, o Design Industrial fornece uma maneira mais otimista de olhar para o futuro, reformulando os problemas como oportunidades. Ele vincula a inovação, tecnologia, pesquisa, negócios e clientes para fornecer novo valor e vantagem competitiva em todas as esferas econômicas, sociais e ambientais. (WDO, tradução nossa) $)^{3}$.

O Design, desde o seu surgimento durante a Revolução Industrial na Europa, sofreu influências de diferentes segmentos artísticos e produtivos da sociedade, assim como repercutiu estrategicamente em situações de concepção e

\footnotetext{
${ }^{3}$ Trecho original: Industrial Design is a strategic problem-solving process that drives innovation, builds business success, and leads to a better quality of life through innovative products, systems, services, and experiences. Industrial Design bridges the gap between what is and what's possible. It is a trans-disciplinary profession that harnesses creativity to resolve problems and co-create solutions with the intent of making a product, system, service, experience or a business, better. At its heart, Industrial Design provides a more optimistic way of looking at the future by reframing problems as opportunities. It links innovation, technology, research, business, and customers to provide new value and competitive advantage across economic, social, and environmental spheres. Fonte: http://wdo.org/about/definition/
} 
aperfeiçoamento de produtos e serviços. O Design se constituiu mundialmente ao longo dos anos como uma atividade interdisciplinar e estratégica, capaz de promover reverberações positivas em diferentes setores econômicos e culturais da sociedade.

As transformações tecnológicas, artísticas e sociais puderam impactar o papel do Design na sociedade, conduzindo-o em reformulações sobre sua prática. É possível considerar que, sem as certezas do paradigma da época anterior, o Design enfrenta um período de insegurança e de incertezas, caracterizado, sobretudo, pelo pluralismo e pela convivência com a complexidade. Nos dizeres de Cardoso (2004, p. 208), "o design vem se libertando da rigidez normativa que dominou o campo durante mais de meio século".

A partir das reflexões sobre a definição do conceito de Design, é possível considerá-lo não apenas como uma atividade que circunda somente no âmbito da produção seriada de artefatos industriais. Ele deve ser compreendido como um processo interdisciplinar e estratégico de projetar produtos e serviços. Entende-se o Design como uma atividade que vem se adequando aos vários cenários que surgem em diferentes épocas. Logo, torna-se fundamental perceber essa atividade como uma prática capaz de corresponder à diversidade, às possibilidades de construção de valores, ao multiculturalismo e à própria dinamicidade presentes no contexto contemporâneo. O Design como uma atividade tipicamente interdisciplinar poderá contribuir para a construção e configuração de Ambientes Virtuais de Aprendizagem.

\section{3}

\section{Relações entre Educação a Distância e Design e as possíveis repercussões em AVAs}

Apresentados preliminarmente nas subseções anteriores os aspectos conceituais da Educação a Distância e do Design, discutiremos aqui acerca das relações entre esses dois campos, com vistas a tratar da construção e configuração de Ambientes Virtuais de Aprendizagem.

A construção e configuração de Ambientes Virtuais de Aprendizagem é uma prática que vem se consolidando nas últimas décadas. $\mathrm{O}$ desenvolvimento das Tecnologias Digitais de Informação e Comunicação e a expansão da oferta de cursos na modalidade a distância é algo que tem impulsionado o surgimento de 
novos AVAs no contexto contemporâneo. Eles possibilitam a realização de práticas de integração de diversos recursos e viabilizam as interações síncronas e assíncronas, permitindo a promoção de trocas de conteúdos e de atividades no contexto de ensino-aprendizagem.

E válido destacar que os Ambientes Virtuais de Aprendizagem têm demandado a participação de diferentes profissionais atuando de maneira colaborativa e considerando o feedback de usuários no contexto da $\mathrm{EaD}$. Como é sabido, a promoção de cursos na modalidade a distância demanda o aprimoramento de recursos e estratégias para essa modalidade. Sendo assim, há diferentes concepções e nomenclaturas utilizadas para conceituar tais ambientes que contribuem para a consolidação de proposta e oferta de cursos na EaD.

Conforme Tori (2010), há várias denominações utilizadas para os sistemas virtuais de gerenciamento de conteúdo, ensino-aprendizagem. Utilizam-se termos tais como: AVA (Ambiente Virtual de Aprendizagem); LMS (Learning Management System); CMS (Course Management System ou Content Management System); LCMS (Learning Content and Management System); IMS (Instructional Management System). Nesta pesquisa utilizaremos o termo AVA para designar esses espaços virtuais hospedados na internet onde se consolidam as interações entre sujeitos, objetos e conteúdo, em situações de ensino-aprendizagem, no qual se estabelecem as trocas de informações e a construção do conhecimento em rede.

Ainda conforme Tori (2010), considera-se que os recursos disponíveis nos Ambientes Virtuais de Aprendizagem são comumente reconhecidos por seus usuários, podendo ser relacionados e apresentados em 12 categorias, conforme segue:

- Gerenciamento do curso: possibilita a criação de cursos, disciplinas, matrícula de educandos, gerenciamento de senhas, registro de atividades e de acessos realizados pelos usuários, cálculo e publicação de notas etc.

- Gerenciamento de conteúdo: esse recurso permite armazenamento, gerenciamento, edição e exibição de conteúdo multimídia.

- Disco virtual: área de trabalho que pode ser individual ou compartilhada, na qual o usuário pode fazer downloads, uploads e visualização de conteúdo. 
- Correio eletrônico (e-mail): é um serviço de correio eletrônico convencional; alguns permitem o envio e o recebimento de mensagens apenas dentro do próprio sistema, outros possibilitam troca de mensagens também com o exterior.

- Mensagem instantânea: trata-se de um serviço de mensagem que possibilita a comunicação síncrona e a troca de documentos entre usuários que estejam conectados ao sistema.

- Sala de bate-papo (chat room): trata-se de um espaço destinado aos encontros e troca de mensagens síncronas, podendo ser de texto, voz ou vídeo.

- Fórum de discussão: recurso de comunicação assíncrona que possibilita a organização das discussões por assunto, por disciplina, por curso, por turma, por grupo, etc.

- Quadro de avisos: é uma área para publicação de informes de interesse geral.

- Lousa virtual (white board): trata-se de um recurso de comunicação síncrona no qual os usuários compartilham uma tela que pode receber desenhos, textos e outras mídias; o instrutor pode liberar a lousa virtual apenas para visualização ou permitir o compartilhamento para escrita com um ou mais dos participantes.

- Compartilhamento de recursos: permite que um ou mais usuários compartilhem a tela, um documento ou recursos de seus computadores.

- Avaliação: recursos para gerenciamento da aplicação e correção de avaliações (testes de múltipla escolha ou provas dissertativas), com possibilidade de sorteio de questões e de alternativas, programação de horário para disponibilização da avaliação aos educandos, controle de tempo de realização, correção automática, cálculo e publicação de médias, geração de estatísticas e até mesmo feedback automático ao educando sobre o seu desempenho.

- Área de apresentação do estudante: trata-se de uma funcionalidade que oferece ao educando, ou grupo de educandos, recursos similares aos disponíveis ao educador para publicação de conteúdo multimídia. 


\section{4}

\section{Ambientes Virtuais de Aprendizagem: iniciativas brasileiras}

A construção e configuração de Ambientes Virtuais de Aprendizagem no contexto atual é uma atividade que potencialmente necessita da atuação de designers na elaboração de projetos de modo que se desenvolvam espaços virtuais que possam facilitar a interação entre usuários, permitam um reconhecimento simplificado das funcionalidades e uma configuração de projetos de modo a tornar mais funcionais, ergonômicos e confortáveis tais ambientes.

Particularmente no Brasil, encontram-se algumas iniciativas dedicadas à construção de AVAs desenvolvidas em centro de pesquisas em universidades. Assim, é possível destacar quatro proposições, conforme mencionadas a seguir: Projeto COL (cursos on-line); Plataforma Teleduc; Projeto Tidia-AE; Projeto Amadeus, entre outros. Desse modo, apresentaremos sumariamente algumas das características desses quatro ambientes.

\subsection{1 \\ O Projeto COL (Cursos on-line)}

COL - cuja sigla corresponde a "Cursos on-line" - é um sistema de gerenciamento e apoio às propostas de ensino-aprendizagem baseado na Web, criado pelo Laboratório de Arquitetura de Redes de Computadores (Larc) do Departamento de Engenharia de Computação e Sistemas Digitais da Universidade de São Paulo - USP. O projeto foi concebido em meados de 2002, com o intuito de ser um ambiente virtual de apoio às aulas ministradas pela Escola Politécnica da USP. Entretanto, a proposta expandiu e passou a ser utilizada em várias outras práticas formadoras da Universidade.

O sistema COL é um recurso, conforme sinaliza Larc (2016), que disponibiliza a organização de cursos no formato de "módulo" (espécie de objeto de aprendizagem que contém uma unidade de conteúdo), "disciplina” (conjunto de módulos) e "turma" (conjunto de educandos). Cada turma pode ser associada a diferentes disciplinas, e cada disciplina pode pertencer a mais de uma turma. As disciplinas podem estar associadas a um conjunto de módulos, que podem conter mais de uma disciplina. Nesse sentido, quando se modifica o conteúdo de um 
módulo, todas as disciplinas correspondentes que o utilizam serão, consequentemente, atualizadas.

O COL oferece alguns recursos de caráter de gerenciamento do curso e das atividades das turmas, assim como funcionalidades ligadas aos aspectos de comunicação e realização de tarefas.

O recurso da Agenda é disponibilizado para que o educador possa anotar tarefas e compromissos pessoais ou da turma. Quando configurado para agendar uma tarefa para a turma, torna-se visível aos educandos. O Correio é um recurso para gerenciar mensagens oriundas de e-mail. No Fórum disponibilizam-se os recursos convencionais de fóruns de discussão acrescidos de funcionalidades específicas, tais como avaliações e comentários do educador; configuração de tópicos a serem discutidos e visualização dos resultados das discussões, de forma gráfica ou textual pelo educador. Já o Chat é recurso clássico de comunicação síncrona. Nesse recurso, cada turma possui uma sala de chat, que fica disponível para uso com a possibilidade de acesso e visualização do histórico da sala.

A funcionalidade de Pesquisa de avaliação possibilita realizar avaliações dos conhecimentos iniciais dos educandos com o objetivo de propiciar o planejamento das atividades dos cursos; podem ser gerados gráficos ou relatórios dos resultados das avaliações. O recurso de Testes permite a criação de testes avaliativos pelo educador a serem realizados pelos educandos ao final de cada módulo.

O recurso de Atividades é disponível para o tutor/educador configurar uma tarefa a ser realizada pelos educandos e programar a sua data para sua entrega. Há também o recurso de Dúvidas, que permite ao educador ou tutor responder às dúvidas que surgem dos educandos. E, finalmente, o recurso Estatísticas, que possibilita ao educador obter informações estatísticas sobre acesso aos seus módulos, disciplinas ou turmas, sendo classificada por diferentes aspectos, como educando e datas dos conteúdos.

\subsection{2}

\section{A Plataforma Teleduc}

O Teleduc é uma plataforma livre, desenvolvida no Brasil pelo Núcleo de Informática Aplicada à Educação (Nied) e pelo Instituto de Computação (IC), da Universidade Estadual de Campinas (Unicamp). Esta plataforma foi concebida em 
1997, mas o seu lançamento oficial ocorreu em 2001. O Teleduc possui uma interface baseada na Web, sendo preciso que o estudante acesse o navegador da internet para utilizá-la. Os recursos principais do Teleduc são os listados a seguir.

A Agenda é um recurso disponível na página inicial da plataforma, o qual apresenta a programação do curso. Avaliações é uma funcionalidade que permite a programação de avaliações on-line e/ou cadastramento de avaliações pelo tutor/educador. Já o Material de apoio possibilita armazenar orientações e materiais complementares para desenvolvimento do curso, disponibilizados pelos tutores/educadores aos educandos.

Leituras disponibiliza um local para armazenamento de textos oferecidos pelos tutores/educadores aos educandos. Perguntas frequentes é um recurso que permite a realização de questionamentos que surgem de educandos com maior constância. Há também o recurso Enquetes, que permite a criação e o acompanhamento de pesquisas rápidas de opinião. O Mural corresponde a um quadro de avisos, aberto a todos os participantes para leitura e publicação.

Fórum de discussão e correio são recursos convencionais de comunicação assíncrona. Já o Bate-papo é um recurso de comunicação síncrona. A funcionalidade Grupos possibilita a criação de grupos de participantes para trabalho colaborativo. O recurso Perfil possibilita a autoapresentação de cada integrante dos cursos.

Portfólio permite o armazenamento de arquivos e links contendo produções dos integrantes dos cursos. Acessos permite acompanhar e fazer relatórios dos acessos ao sistema realizados pelos participantes. Finalmente, a função Intermap é um recurso que apresenta graficamente as interações realizadas pelos educandos nas ferramentas bate-papo, correio e fórum de discussão, além de possibilitar uma rápida visualização da intensidade e da distribuição das interações.

\subsection{3}

\section{O Projeto Tidia-AE}

O Ae é uma plataforma desenvolvida dentro do projeto Tidia-AE (Tecnologia da Informação para o Desenvolvimento da Internet Avançada - Aprendizagem Eletrônica) na Universidade de São Paulo (USP). O Projeto teve início em setembro de 2004, com participação de 15 laboratórios de instituições do estado de São Paulo. 
A plataforma é organizada em diferentes áreas de trabalho com distintas funcionalidades, permitindo que tutores possam criar cursos, gerenciá-los, além de possibilitar aos educandos participarem de maneira colaborativa da execução de trabalhos, tarefas, pesquisas e projetos.

O Ae é baseado o sistema Sakai, software gratuito de código aberto para gerenciamento de cursos on-line, mantido pela Fundação Sakai, que é composta de diversos membros, entre eles as universidades MIT, Columbia, Oxford e Stanford. O sistema é desenvolvido em linguagem Java e se utiliza dos componentes de software MySQL e Apache Tomcat. O Ae/Sakai possibilita a convivência de diferentes implementações para o mesmo tipo de serviço, por exemplo, mais de um serviço de chat ou de whiteboard.

O Ae/Sakai disponibiliza aos usuários diversas funcionalidades, conforme apresentado na relação que segue:

- Início: mostra um resumo do estado das ferramentas do sistema, como avisos, e-mails, eventos agendados, chats realizados.

- Avisos: exibe avisos, críticas, elogios e informações.

- Assignments: gerencia atribuições e recebe submissões on-line.

- Bate-papo: permite a participação do usuário em tempo real para conversas via chat com um grupo de pessoas.

- Discussão: permite a discussão entre usuários, mas não em tempo real.

- Escaninho: permite que educandos, instrutores e educadores compartilhem arquivos e documentos de forma privada.

- Caixa de mensagens: mantém um histórico de todos os e-mails enviados para a lista de do worksite.

- Quadro de notas: calcula o histórico de notas.

- Ajuda: permite o acesso aos tutoriais de ajuda.

- Associação aos worksites: permite a seleção de sites de que o usuário deseja participar.

- Novidades: notifica o usuário das últimas alterações nas ferramentas dos worksites a que ele está associado.

- Preferências: possibilita o ajuste de fusos horários, ordem das abas etc. 
- Apresentações: permite a apresentação de slides em tempo real, sincronizados com o educador, além da navegação pelos slides, independentemente do educador.

- Profile: permite que os usuários publiquem informações pessoais, incluindo foto.

- Recursos: possibilita a adição de documentos e endereços de websites (URLs) para o seu worksite.

- Participantes: disponibiliza lista dos participantes no site.

- Cronograma: possibilita a visualização e marcação de datas e de fins de prazos importantes no calendário do worksite.

- Informação de turma: possibilita o controle de seções ou de grupos dentro de um site.

- Site info: mostra o perfil do worksite e a lista dos participantes.

- Conteúdo programático: cria um plano de estudos para o worksite.

- Exercícios: cria, administra e corrige testes e quizzes on-line e alimenta automaticamente o quadro de notas.

- Links: inclui índices externos de portais em seu worksite.

- News: lê notícias de sites em formato RSS.

- Sistemas administrativos: importa turmas cadastradas nos sistemas administrativos das instituições de ensino para o ambiente Ae.

- NetLab: agenda e gerencia recursos, experiências e laboratórios.

\subsection{4}

\section{O Projeto Amadeus}

O Projeto Amadeus foi desenvolvido em 2007 pelo grupo Ciências Cognitivas e Tecnologia Educacional (CCTE) da Universidade Federal de Pernambuco (UFPE). Os criadores do AVA o definem como um "sistema de gestão da aprendizagem de segunda geração, baseado no conceito de blended learning". O Projeto Amadeus tem como objetivo principal contribuir com o desenvolvimento social pela formação e educação para todos, reduzindo custos, gerando empregos e negócios, e, consequentemente, aperfeiçoando o atendimento ao cidadão e favorecendo a democratização do acesso ao conhecimento. 
A proposta de seus idealizadores foi integrar de forma simplificada diferentes mídias e plataformas (internet, desktop, celulares, PDAs e - prometida para um futuro próximo - TV Digital). O projeto teve origem em estudos qualitativos das práticas de educadores, tutores e educandos em condições de interação em cursos a distância.

Amadeus (Agentes Micromundos e Análise do Desenvolvimento no Uso de Instrumentos) apresenta-se como uma possível plataforma de gestão da aprendizagem de segunda geração. O recurso através das abordagens orientadas por conceitos dos campos da Informática, Ergonomia, Pedagogia, e áreas afins, tem como foco o atendimento aos requisitos e demandas dos educandos e usuários em situação de ensino-aprendizagem.

Entre as principais características do sistema Amadeus, destacam-se:

- Interface: utiliza Java/Ajax, tecnologia empregada por boa parte das aplicações da chamada Web 2.0, visualização de dados e serviços de percepção na interface da aplicação Web.

- Arquitetura: integra servidor e cliente de jogos flash multiusuários, servidor e plataforma de componentes síncronos de aprendizagem, e servidor multimídia multiusuários.

- Modelos de aprendizagem: possibilita diferentes abordagens de aprendizagem: construtivista (manipulações sobre representações) e sociointeracionista (colaboração, engajamento, imersão em jogos).

- Mídias: permite o acesso a cursos originados na plataforma em canais de TVDi ou T-learning; a inclusão de novas mídias, como jogos e vídeos na internet; possibilita o acesso por plataformas outras que não a internet, por meio de módulos especiais.

- Mobile Learning ou M-learning: envio de SMS sinalizando a tomada de consciência das atividades continuadas que ocorrem na plataforma.

O software de instalação da plataforma é gratuito (licença GNU-GPL2) e pode ser instalado em diversos sistemas operacionais (Unix, Linux, Windows, Mac OS), desde que estes consigam executar a linguagem Java. Como base de dados, podem ser utilizados MySQL, PostgreSQL, Oracle, Access, Interbase ou ODBC, 
pois o mesmo usa a tecnologia Hybernate. O projeto é desenvolvido de forma colaborativa por uma comunidade virtual que reúne programadores e desenvolvedores de software livre, administradores de sistemas, educadores, designers instrucionais e usuários. Sua localização para outros idiomas além do português é simples. Documentação e código encontram-se à disposição na página do projeto.

\section{5}

\section{Ambientes Virtuais de Aprendizagem: iniciativas internacionais}

No contexto internacional, é possível identificar diversos Ambientes Virtuais de Aprendizagem. Entre os mais utilizados, encontram-se: Moodle, Blackboard, Open EDX, Coursera e Edmodo. Sendo assim, apresentaremos a seguir, sumariamente, algumas das características desses cinco ambientes que se destacam.

\subsection{1 \\ O Ambiente Virtual de Aprendizagem Moodle}

O ambiente denominado Modular Object Oriented Distance Learning Moodle - é um software livre ${ }^{4}$, de apoio à aprendizagem. A expressão corresponde ainda a um Sistema de Gestão da Aprendizagem (Learning Management System) em ações colaborativas baseada nesse software ou plataforma, acessível através da Internet ou de rede local. O Moodle é definido como "uma plataforma de aprendizagem projetada para fornecer aos educadores, administradores e educandos um sistema integrado onde é possível criar ambientes de aprendizagens personalizados" (Moodle, 2015). Este ambiente foi concebido em 2001, pelo educador e cientista computacional Martin Dougiamas. O Moodle tem como objetivo o gerenciamento do aprendizado e do trabalho colaborativo em ambiente virtual, permitindo a criação e administração de cursos on-line, grupos de trabalho e comunidades de aprendizagem.

\footnotetext{
${ }^{4}$ A Free Software Foundation considera um software como livre quando atende aos quatro tipos de liberdade para os usuários: a liberdade para executar o programa, para qualquer propósito; A liberdade de estudar o software; A liberdade de redistribuir cópias do programa de modo que você possa ajudar ao seu próximo; A liberdade de modificar o programa e distribuir estas modificações, de modo que toda a comunidade se beneficie. (Free Software Foundation, 2016.)
} 
O ambiente Moodle, além de ser um software livre, é também de código aberto (open source) ${ }^{5}$. Permite realizar adaptações ou modificações em seu código de forma espontânea, ou seja, sem que haja a necessidade de solicitar permissão ao seu proprietário para modificá-lo. Os usuários têm a liberdade de estudar e modificar software pela disponibilidade do código-fonte, bem como a liberdade de copiar e distribuir. Já a característica de código aberto é atribuída apenas sob um ponto de vista técnico e permite ao usuário que o adapte às suas necessidades sem prescindir de autorização do programador que desenvolveu o programa. O Moodle, além ser livre e de código aberto, é um ambiente possível de ser modelado para se adequar às necessidades e ao projeto de cursos de cada instituição.

Os recursos disponíveis no Moodle possuem interfaces para interação síncrona e assíncrona entre os educandos-usuários do processo de ensinoaprendizagem, estando baseado em uma concepção de aprendizagem construtivista e colaborativa. Conforme Dougiamas, $(2015$, p.1) a proposta de desenvolvimento do Moodle não se direciona a apenas reconhecer a aprendizagem como uma atividade social, “(...) mas focaliza a atenção na aprendizagem que acontece enquanto construímos ativamente artefatos (como textos, por exemplo), para que outros os vejam ou utilizem".

\section{5 .2}

\section{O Ambiente Virtual de Aprendizagem Blackboard}

O Blackboard é um Ambiente Virtual de Aprendizagem de caráter proprietário, que demanda das instituições que o utilizam estabelecer um contrato de licença. O AVA é desenvolvido pela empresa Blackboard Inc., que atua como produtora e fornecedora de softwares e serviços para a modalidade de educação online. Criado em 1997, trata-se de um ambiente que apresenta recursos de gestão de cursos, suportes de instrução, meios de comunicação e gerenciamento de conteúdo. De modo geral, as funcionalidades do Blackboard se assemelham às do AVA Moodle. Desta maneira, apresentam-se a seguir algumas das características disponíveis nesse ambiente.

\footnotetext{
${ }^{5} \mathrm{O}$ termo código aberto, ou open source, em inglês, foi criado pela OSI (Open Source Initiative) e difere de um software livre por não considerar as quatro liberdades definidas pela Free Software Foundation. Qualquer licença de software livre é também uma licença de código aberto (Open Source), mas o contrário nem sempre é verdade. (Open Source Initiative, 2016)
} 
- Criação de cursos: através de um fluxo simples de trabalho, o ambiente viabiliza aos usuários utilizar o assistente para produzir a configuração inicial de um curso.

- Gestão do curso: o AVA possibilita que os educadores e tutores possam atualizar e reconfigurar os recursos dos cursos. O conteúdo do curso: permite que os educadores e tutores possam publicar artigos, materiais, trabalhos, vídeos etc.

- Calendário: pode ser usado para postar datas de vencimento para tarefas e testes.

- Avaliações e pesquisas: possibilita aos educadores e tutores entregarem avaliações e pesquisas on-line, agendadas automaticamente.

- Exercícios e atividades: podem ser postados, e os educandos podem apresentar trabalhos on-line.

- Controle da disponibilidade: os educadores e tutores podem criar caminhos de aprendizagem personalizados para determinar quando os educandos podem acessar itens de conteúdo, discussões, avaliações, tarefas e outras atividades de aprendizagem.

- Centro de classificação: armazenamento de resultados e desempenho do estudante, incluindo suporte para escalas de classificação personalizada, ponderação de grau, incluindo análise e múltiplas visões do centro de série.

\subsection{3}

\section{O Ambiente Virtual de Aprendizagem EDX}

O ambiente virtual EDX é uma plataforma criada em 2012 com o objetivo de oferecer cursos e estudos abertos e on-line, produzida e mantida pelas instituições Universidade de Harvard e Instituto de Tecnologia de Massachusetts (MIT). A definição desse ambiente pelos seus idealizadores é "uma plataforma disponível como open source" (EDX, 2015). A oferta de cursos ocorre por meio da associação com outras instituições em um formato de consórcio chamado de "xConsortium". As universidades de Toronto, Berkeley, Hong Kong e Seul compõem, entre outras 36 instituições, o conjunto das parcerias do projeto. 
As aulas são oferecidas no formato de cursos on-line abertos em grande escala, reconhecidos como Cursos Online Abertos e Massivos, do inglês Massive Open Online Course (MOOC). Através da plataforma EDX, universidades e instituições de ensino podem hospedar e oferecer cursos autorais e disponibilizálos ao público em geral. Paralelamente à proposta de oferta de cursos on-line, as instituições associadas também utilizam a plataforma EDX para pesquisar como os educandos aprendem e como as tecnologias podem aprimorar os processos de ensino-aprendizagem.

Os mantenedores do EDX explicitam que os objetivos dessa plataforma estão alicerçados em torno da proposta de torná-la um recurso no qual educandos possam aprender de modo colaborativo e abrangente na web. Expõem, assim, seus objetivos: "Expandir o acesso à educação para todos, melhorar o ensino e a aprendizagem presencial e on-line e ensino-aprendizagem avançada através da investigação" (EDX, 2015). E os princípios estabelecidos são: "Sem Fins Lucrativos, Plataforma de código aberto, Colaborativo, Financeiramente sustentável” (EDX, 2015).

\subsection{4}

\section{O Ambiente Virtual de Aprendizagem Coursera}

O Coursera é, assim como o EDX, um Ambiente Virtual de Aprendizagem que oferece "Cursos Online Abertos e Massivos". O ambiente Coursera foi criado em 2012 pelas universidades norte-americanas de Stanford, Princeton, Michigan e Pennsylvania, e, atualmente, possui cerca de 90 instituições associadas à proposta. No Brasil, têm-se a Universidade de São Paulo (USP) e a Universidade Estadual de Campinas (Unicamp), que fizeram adesão à proposta e ofertam cursos nesse ambiente. Através do Coursera são oferecidos de forma gratuita diversos cursos a distância em diversas áreas do conhecimento.

A definição desse ambiente pelo fornecedor é explicitada com os seguintes dizeres: "O Coursera é uma plataforma de ensino que realiza parcerias com as melhores universidades e instituições de ensino em todo o mundo, para oferecer cursos online e gratuitos a todos" (Coursera, 2015).

De modo geral, os cursos oferecidos no ambiente Coursera são disponibilizados através de videoaulas gravadas e veiculadas de modo linear por 
meio de transferência de arquivo (streaming). São realizados testes on-line automatizados no formato de pergunta-resposta e fomentada no ambiente a realização de avaliações por educandos matriculados e por educadores dos cursos. O desenvolvimento de avaliações por educandos-colegas é uma técnica adotada nos cursos com o objetivo de promover a interação entre os educandos-usuários e viabilizar a correção das atividades.

A proposta de cursos nessa plataforma é baseada em métodos de ensino delimitados em quatro fundamentos norteadores: a eficácia da "Aprendizagem Online"; "Pedagogia de Domínio"; "Avaliação entre Colegas" e a "Educação Mista". No caso da vertente de "Aprendizagem On-line", preconiza-se pelos idealizadores que o formato de ensino on-line é mais eficaz que os métodos tradicionais de ensino. A vertente da "Pedagogia de Domínio" possui seu foco na ideia de que os educandos necessitam dominar determinado tema antes de passar para os conteúdos mais avançados. Neste caso, se um conceito não for compreendido pelo educando, o feedback é imediato, e sequencialmente são oferecidas atividades em versões alternativas de modo que o estudante possa fazer e refazer as tarefas até dominar o conteúdo.

A terceira vertente oferecida na plataforma Coursera, denominada "Avaliação entre Colegas", está baseada no conceito de que muitos cursos possuem atividades significativas que não podem ser corrigidas automaticamente por computadores. Neste caso, o ambiente utiliza um método no qual os educandos podem avaliar e enviar seus comentários acerca dos trabalhos uns dos outros. Finalmente, a quarta vertente do Coursera fundamenta-se na ideia de que a "Educação Mista", de parceria com a metodologia específica das instituições associadas, é capaz de proporcionar aos educandos uma experiência significativa de aprendizado, ampliando o seu envolvimento, frequência e desempenho.

Nota-se que as funcionalidades e as estratégias adotadas nesse formato de plataforma revelam a necessidade de um perfil de estudante com a habilidade de se adaptar a um modelo de ensino diferente do formato convencional. Necessita que os educandos tenham certas habilidades e competências, tais como disciplina com os estudos, comprometimento com as atividades, autonomia e capacidade de gerenciamento do ritmo de seu aprendizado. 


\subsection{5 \\ O Ambiente Virtual de Aprendizagem Edmodo}

O ambiente Edmodo é definido como "uma comunidade social de aprendizagem" (Edmodo, 2015), que possibilita a hipertextualidade, em que os educadores e educandos têm a possibilidade de interagir, publicar e compartilhar imagens, textos, arquivos de áudio e vídeo. Além disso, o ambiente permite a inclusão de links, textos, enquetes e quizzes. Neste sentido, o ambiente favorece a promoção de ações que podem despertar o envolvimento dos educandos no processo de ensino-aprendizagem.

O Edmodo possui uma interface similar ao das redes sociais digitais, tal como o Facebook, e apresenta-se como uma plataforma de simples navegação. O ambiente possibilita o acompanhamento das atividades realizadas pelos educandosusuários e permite a atribuição de notas de aproveitamento nas atividades propostas. Alguns dos limites percebidos no ambiente Edmodo são a impossibilidade da produção colaborativa de textos, como o uso de wikis, além da ausência de recursos de comunicação síncrona, como chats em tempo real, conversação e visualização de participantes com o uso de webcam. O ambiente dispõe de um espaço para montagem de uma biblioteca virtual, possibilitando ao educador disponibilizar arquivos e materiais educacionais a serem utilizados pelos educandos-usuários.

O Edmodo pode ser reconhecido como um ambiente interativo dedicado a potencializar a comunicação entre os seus usuários, promovendo, dessa maneira, situações em que os educandos-usuários aprendam de modo colaborativo. Embora o ambiente não possua recursos de comunicação síncrona, é possível considerar as possibilidades de associação com outros recursos digitais on-line que podem ser adaptados nas práticas educativas.

\section{6}

\section{A Interação em Ambientes Virtuais de Aprendizagem}

Diferentes concepções teóricas sobre a aquisição ou construção do conhecimento podem ser identificadas na busca por compreender os modos como o ser humano aprende e se desenvolve. Algumas dessas concepções são divergentes, e outras se complementam no intuito de elucidar questões que envolvem a aprendizagem e o desenvolvimento do pensamento humano. Em todas 
essas visões e formulações, encontramos necessariamente uma relação entre o sujeito e o objeto de conhecimento. Há concepções teóricas que buscam basicamente explicar como se dá a apreensão do conhecimento. Já outras se baseiam na ideia de que a interação entre sujeito e objeto é o elemento essencial no processo de construção do conhecimento e do desenvolvimento humano.

No campo da Psicologia, encontramos a teoria Interacionista de Jean Piaget e a teoria Sociointeracionista de Lev Vygotsky. As formulações desses dois estudiosos contribuem tanto para o entendimento de questões ligadas ao conhecimento no campo da Psicologia como também da Educação, ao elucidar as possíveis relações entre o desenvolvimento humano e a aprendizagem.

A teoria de Jean Piaget, intitulada "Epistemologia Genética", foi concebida tendo como premissa o fato de que o conhecimento é construído a partir da interação do sujeito com seu meio (Piaget, 1974). Piaget formulou essa teoria a partir de suas experiências e da fusão de duas outras teorias existentes. Ele não estava convencido de que o conhecimento fosse, a priori, inerente ao próprio sujeito (apriorismo), nem que o conhecimento decorresse totalmente das observações do meio que o cerca (empirismo).

Na visão de Piaget, o conhecimento, em qualquer nível, é construído por meio de uma interação radical do sujeito com seu meio, a partir de estruturas previamente existentes no sujeito. Deste modo, a aquisição de conhecimentos depende tanto de certas estruturas cognitivas inerentes ao próprio sujeito como também de sua relação com o objeto, assim não priorizando ou prescindindo de nenhuma delas.

$\mathrm{Na}$ abordagem proposta por Piaget, temos um modelo teórico qualificado como interacionista. Nessa perspectiva, o conhecimento não é imanente ao sujeito nem ao objeto. Ele é construído pela interação entre o sujeito e o objeto. Deste modo, na concepção de Piaget (1974), o desenvolvimento cognitivo é um processo de construção que ocorre a partir da interação entre sujeito e objeto. Nesse processo, o sujeito é entendido como um ser ativo e responsável pelo seu desenvolvimento. Assim, o conhecimento não está nem no sujeito cognoscitivo nem no objeto do conhecimento, ele é construído a partir da interação entre eles.

Considerando que Piaget (1974) tenha dedicado quase que exclusivamente seus estudos à Epistemologia e à Psicologia, não se pode negar que suas explicações sobre o processo de aquisição de conhecimento impactaram o campo da Educação. 
As formulações de Piaget serviram como base e suporte ao surgimento de inúmeras reflexões acerca da prática pedagógica.

Já as formulações de Lev Vygotsky baseiam-se na dialética das interações do sujeito com o outro e com o meio para que possa ocorrer o desenvolvimento sociocognitivo (Vygotsky, 1999). O conceito de interação social é um dos focos dos postulados de Vygotsky, que destaca a dialética entre o indivíduo e a sociedade. Enfatiza o intenso efeito da interação social, da linguagem e da cultura sobre o processo de aprendizagem

Vygotsky conduziu seus estudos tendo uma preocupação com o contexto sociocultural do indivíduo, considerado um elemento fundamental para o seu desenvolvimento. Na teoria de Vygotsky, não encontraremos uma abordagem orientada por etapas, como em outras teorias formuladas por estudiosos precursores. Vygotsky dá ênfase ao contexto histórico, social e cultural e considera o sujeito como ativo no processo de desenvolvimento cognitivo. Assim, formulou uma teoria interacionista distinta, concebendo uma obra abrangente e mais coerente do ponto de vista epistemológico.

Conforme Palangana (2015),

Vygotsky apoiou-se no materialismo histórico. Isso lhe permitiu defender um interacionismo em que se prioriza, de fato, a interação entre indivíduo e meio ambiente (entendido como o contexto sócio-histórico em que se vive), admitindo-se, dessa forma, uma determinação mútua entre ambos. Ao conceber o desenvolvimento humano como um processo em íntima vinculação com a atividade prática dos homens, Vygotsky construiu uma teoria essencialmente interacionista para explicar como se dá o desenvolvimento das funções psíquicas superiores.

Piaget, por outro lado, servindo-se do método estruturalista, centrou sua atenção no polo do sujeito, encarando o objeto apenas como elemento potencialmente perturbador da estrutura cognitiva. Desse modo, não há no construtivismo piagetiano trocas recíprocas e influências equitativas entre os dois polos da unidade de conhecimento, o que caracteriza a natureza da abordagem interacionista. Não se nega, no entanto, que Piaget seja um interacionista: a interação entre criança e meio como um dos fatores responsáveis pela gênese do pensamento está clara em sua teoria. (Palangana, 2015, p.133).

Em seus estudos, Vygotsky (1999) fez várias formulações como parte integrante de uma análise geral do desenvolvimento humano. No entanto, com o intuito de enfatizar a diferença entre o desenvolvimento relacionado às leis biológicas (maturação) e o desenvolvimento mental (aprendizagem realizada no 
cotidiano) construído da relação eu-contexto social, o autor formula o conceito de Zona de Desenvolvimento Proximal (ZDP).

Para Vygotsky, a aprendizagem acontece dentro de uma zona de desenvolvimento proximal. Sendo assim, há uma diferença entre o que a criança sabe fazer sozinha e seu nível de desenvolvimento potencial, que é determinado por meio de resolução de problemas sob orientação adulta ou em colaboração com seus semelhantes mais capazes (Vygotsky, 1999).

Nessa perspectiva, a interação em processos educativos é essencial para favorecer o desenvolvimento da aprendizagem dos educandos, a partir das interações com os colegas, educadores e com o conteúdo em que se promove a construção do conhecimento discente. Assim, torna-se necessário proporcionar situações que estimulem a interação em processos de ensino-aprendizagem, bem como disponibilizar aos educadores recursos que favoreçam e estimulem tal interação. A possibilidade de gerar interação com o conteúdo a ser estudado, com seus colegas de turma e com os educadores está tanto no âmbito da prática docente como nos recursos disponíveis

Nessa concepção, o educador necessita compreender a importância do diálogo como uma prática essencial em suas aulas, propiciando aos educandos a oportunidade de aprender a partir da interação e da curiosidade. O educador assume o lugar de mediador e não mais de um mero transmissor de conhecimentos. Os educadores atuam como articuladores das experiências dos educandos com a realidade que os cerca, estimulando a reflexão e uma postura crítica sobre seu entorno.

Para Vygotsky (1999), a interação social e a mediação são elementos centrais nos processos de ensino-aprendizagem. Assim, no planejamento da prática escolar, é necessário considerar o estudante como um sujeito em permanente transformação, com a capacidade de agir e intervir no mundo, conferindo novos significados e sentidos na vida em sociedade.

Considerando as postulações de Vygotsky, é essencial reconhecermos que o estudante se constitui na relação com o outro. E os espaços de aprendizagem, tanto os ambientes físicos quanto os virtuais, tornam-se lugares privilegiados para gerar ações e interações de modo a promover a construção do conhecimento.

Neste sentido, podemos compreender, a partir das concepções de Vygotsky, que os ambientes de aprendizagem (físicos ou virtuais) são lugares oportunos para 
a proposição de atividades compartilhadas entre educandos, mediados pelos educadores. Também nos é possível considerar que a mediação é um elo que se realiza por meio da interação em processos de ensino-aprendizagem.

Assim sendo, os recursos e as funcionalidades de interação disponíveis nos Ambientes Virtuais de Aprendizagem são essenciais nos processos de construção do conhecimento. Entretanto, para que tais recursos sejam de fato eficientes em processos educativos, os docentes necessitam utilizá-los de forma contextualizada e de modo pedagogicamente adequado, com foco nos objetivos, interesses e necessidades para a formação dos discentes.

\section{7}

\section{Significados e Sentidos em Ambientes Virtuais de Aprendizagem}

$\mathrm{O}$ estudo dos discursos produzidos pelos agentes da EaD no uso dos Ambientes Virtuais de Aprendizagem nesta pesquisa se deu a partir da perspectiva trabalhada por Bakhtin (2006), particularmente em sua teoria enunciativa. As percepções, os significados e os sentidos atribuídos aos Ambientes Virtuais de Aprendizagem serão objeto de análise dos capítulos 4 e 6 desta tese. Para tanto, trataremos aqui alguns aspectos relacionados ao conceito de Significados e Sentido, na visão de Bakhtin.

Para o referido autor, a linguagem é um fenômeno socioideológico e somente pode ser analisada em sua complexidade se entendida deste modo. Assim sendo, a linguagem apenas poderá ser compreendida em seu vínculo com a vida, com a materialidade social concreta, no fluxo da história e em constante movimento. Conforme Bakhtin (2006), o produto do ato de fala, ou seja, a enunciação não pode ser considerada como individual, pois ela é a interação de pelo menos duas enunciações. Deste modo, a enunciação é diálogo, é de natureza social.

Mikhail Bakhtin dedicou-se a elucidar como se dá a construção de sentidos por meio da interação social, demonstrando que tanto o discurso interior (a consciência) quanto o discurso exterior são constituídos de um mesmo material semiótico, a palavra.

Nos dizeres de Bakhtin (2006, p. 36):

É preciso fazer uma análise profunda e aguda da palavra como signo social para compreender seu funcionamento como instrumento da consciência. É devido a esse papel excepcional de instrumento da consciência que a palavra funciona como 
elemento essencial que acompanha toda criação ideológica, seja ela qual for. A palavra acompanha e comenta todo ato ideológico.

Em suas formulações, Mikhail Bakhtin também critica a busca de sentidos expressos pelos significados "dicionarizados" das palavras em enunciações. O referido pensador, em suas célebres obras, dá ênfase ao caráter neutro das palavras e seu papel como signo, capaz de assumir sentidos diferentes dependendo do contexto em que se insere.

Nesta etapa da pesquisa, assumimos um percurso metodológico considerando a visão Bakhtiniana, no qual tivemos o intento de levar em conta as dimensões sociais e histórica dos participantes e as relações dialógicas na esfera do discurso na busca de uma construção dos sentidos. Ademais, na análise dos dados, assumimos como suporte a teoria de Vygotsky acerca da construção do conhecimento mediada pelas interações de discursos na Zona Proximal de Desenvolvimento.

Ao reportar-se às contribuições bakhtinianas, Freitas (2005, p. 98) menciona que podemos "pensar que o olhar extraposto a partir do qual [o autor] via a linguagem lhe permitiu valorizar o discurso múltiplo, dialógico, a compreensão de que todo discurso recolhe o discurso alheio". Sendo assim, a análise do discurso tem como objetivo apreender a dimensão do outro na produção e leitura de um enunciado, pois a significação dada à palavra é de natureza social, histórica e variante.

Bakhtin (2006, p.96) enfatiza, nesse sentido:

Na realidade, não são palavras o que pronunciamos ou escutamos, mas verdades ou mentiras, coisas boas ou más, importantes ou triviais, agradáveis ou desagradáveis, etc. A palavra está sempre carregada de um conteúdo ou de um sentido ideológico ou vivencial. É assim que compreendemos as palavras e somente reagimos àquelas que despertam em nós ressonâncias ideológicas ou concernentes à vida.

(...) Essa orientação da palavra em função do interlocutor tem uma importância muito grande. Na realidade, toda palavra comporta duas faces. Ela é determinada tanto pelo fato de que procede de alguém, como pelo fato de que se dirige para alguém. Ela constitui justamente o produto da interação do locutor e do ouvinte. Toda palavra serve de expressão a um em relação ao outro. Através da palavra, defino-me em relação ao outro, isto é, em última análise, em relação à coletividade. A palavra é uma espécie de ponte lançada entre mim e os outros. Se ela se apoia sobre mim numa extremidade, na outra apoia-se sobre o meu interlocutor. A palavra é o território comum do locutor e do interlocutor. (Bakhtin, 2006, p.115) 
Santos \& Moreira (2017) nos chamam a atenção para os cuidados que precisam ser tomados tanto no contexto de entrevistas quanto no de grupos focais, a partir das indicações metodológicas bakhtinianas. Esses autores, corroborando com as formulações de Bakhtin, alertam para o fato de que as enunciações não são monológicas, mas uma corrente dialógica ininterrupta.

Nos dizeres de Santos \& Moreira (2017, p.89):

[...] ao se pensar nas entrevistas, não se deve pensá-las como momentos estanques em que se para o tempo e faz-se uma coleta de dados para depois permitir que a realidade continue; ao contrário, deve-se observar que tanto o contexto histórico quanto o contexto imediato da entrevista estarão presentes nos enunciados, moldando sua forma e seu conteúdo.

Assim sendo, buscaremos nesta pesquisa adotar os conceitos de interação abordados por Jean Piaget e Lev Vygotsky e as concepções de Significados e Sentidos abordados por Mikhail Bakhtin. 


\section{3 \\ Ambientes Virtuais de Aprendizagem e o ensino de Design}

Nesta seção apresentaremos as escolhas e opções assumidas pelas instituições de ensino de Design acerca dos Ambientes Virtuais de Aprendizagem. Nosso intento é avaliar como o campo do Design "observa" ou se "relaciona" com a Educação a Distância, de modo particular com os Ambientes Virtuais de Aprendizagem. Iniciaremos a partir daqui uma verificação do ponto de vista institucionalizado do campo do Design.

O objetivo do presente capítulo é identificar e analisar os Ambientes Virtuais de Aprendizagem utilizados em universidades nacionais e internacionais que ofertam cursos de Design. Foi realizado, como parte desta pesquisa, um levantamento dos AVAs utilizados por diferentes instituições em propostas de Educação a Distância. Este capítulo está em consonância com o primeiro e o segundo objetivos específicos da pesquisa, quais sejam: a) identificar e analisar AVAs utilizados nos cursos de Design em instituições nacionais e internacionais; b) identificar e analisar AVAs utilizados em instituições de ensino superior nacionais e internacionais que ofertam cursos de Design.

A diferença entre o primeiro e o segundo objetivo específico está no fato de que o primeiro se dedicará apenas às faculdades e universidades que ofertam cursos de Design na modalidade a distância. Já o segundo objetivo está voltado para as faculdades e universidades que ofertam, entre outros cursos, o curso de Design mesmo que apenas na modalidade presencial. Neste segundo objetivo buscaremos os AVAs utilizados para a oferta de cursos de um modo geral.

Para essa seleção foram considerados os seguintes critérios: a) o ranking promovido por entidades renomadas, b) instituições que possuem iniciativas em EaD e em Design, c) o acesso a essas iniciativas das instituições para a promoção da análise, d) possibilidade de mapeamento dessas iniciativas de modo a contribuir para esta pesquisa.

A utilização de critérios de ranking teve como finalidade servir apenas como uma delimitação adequada (recorte) da pesquisa. Sabe-se que os rankings de 
instituições carregam ideologias, contradições e circunscrevem-se em diversos interesses, tais como econômicos, políticos, entre outros.

Iniciamos esta fase da pesquisa verificando os rankings existentes, aplicados internacionalmente na classificação das instituições de ensino. Durante a verificação, percebemos a existência de diferentes critérios adotados na avaliação das faculdades e universidades. Também observamos os riscos de inclinação dos rankings aos diversos interesses que poderiam estar implícitos nessas classificações.

Nesta pesquisa foram analisados quatro rankings de entidades internacionais para, em seguida, ser selecionado o mais apropriado. São eles: Red Dot Design; QS World University; Bloomberg Businessweek e o BusinessInsider. Após uma análise desses quatro modelos, observamos que as classificações do Bloomberg Businessweek e do BusinessInsider seguem critérios direcionados a interesses essencialmente de mercado e de negócios, desfavorecendo uma análise de cunho qualitativamente acadêmico.

Assim, optamos por utilizar o modelo de classificação Red Dot Design, concebido essencialmente na análise de cursos de Design, e o modelo QS World University, que avalia variadas instituições de ensino superior. A escolha desses dois rankings foi assim definida também pelo fato de adotarem como critérios de classificação aspectos associados ou correlacionados a ensino, pesquisa e extensão.

\section{1}

\section{Ambientes Virtuais de Aprendizagem e a classificação Red Dot Design}

A classificação do Red Dot Design é específica de universidades internacionais que ofertam cursos de Design. Em seus critérios de classificação, consideram a avaliação por empresas, escritórios da área e profissionais designers atuantes no mercado. O Red Dot Design acompanha e avalia a qualificação de uma instituição pela produção de novos conceitos de Design ao longo de um período de tempo.

As avaliações e classificações das universidades feitas pelo Red Dot Design são categorizadas em dois grupos de instituições: um com universidades localizadas na região da Ásia-Pacífico, englobando grande parte da Ásia Oriental, sul da Ásia, 
sudeste da Ásia e Oceania, e outro grupo de universidades sediadas nos continentes da América e Europa.

Neste estudo, fizemos a opção por analisar apenas as classificações do grupo América e Europa. Utilizamos nesta pesquisa a classificação das instituições de ensino de Design considerando os resultados das edições Red Dot Design nos anos de 2014 a 2017. Compilamos as classificações do período mencionado (Quadro 2):

\begin{tabular}{|c|c|c|c|c|c|}
\hline \multicolumn{4}{|c|}{$\begin{array}{l}\text { Classificação } \\
\text { conforme o ano }\end{array}$} & \multirow[b]{2}{*}{ Instituição } & \multirow[b]{2}{*}{ País } \\
\hline$\underset{⿱}{\mathbf{D}}$ & 옹 & $\stackrel{0}{\circ}$ & 송 & & \\
\hline $1^{\circ}$ & $2^{\circ}$ & $1^{\circ}$ & $1^{\circ}$ & Umeå Institute of Design | Umeå University & Suécia \\
\hline $2^{\circ}$ & 10 & $3^{\circ}$ & $4^{\circ}$ & Art Center College of Design & EUA \\
\hline $3^{\circ}$ & $3^{\circ}$ & $2^{\circ}$ & $3^{\circ}$ & ENSCI - Les Ateliers & França \\
\hline $8^{\circ}$ & $4^{\circ}$ & $4^{\circ}$ & $2^{\circ}$ & Savannah College of Art and Design & EUA \\
\hline $4^{\circ}$ & $6^{0}$ & $6^{\circ}$ & $6^{0}$ & Academy of Art University & EUA \\
\hline $7^{\circ}$ & $5^{0}$ & $5^{\circ}$ & $5^{\circ}$ & Middle East Technical University (METU) & Turquia \\
\hline $5^{\circ}$ & $8^{\circ}$ & $9 \stackrel{0}{2}$ & ---- & California College of the Arts & EUA \\
\hline $10^{\circ}$ & $7^{0}$ & $8^{\circ}$ & ---- & Burg Giebichenstein University of Art and Design & Alemanha \\
\hline---- & $13^{\circ}$ & $7^{0}$ & $13^{\circ}$ & Royal College of Art (RCA) & Inglaterra \\
\hline $6^{\circ}$ & ---- & $15^{\circ}$ & $14^{\circ}$ & The Oslo School of Architecture and Design (AHO) & Noruega \\
\hline---- & ---- & $10^{\circ}$ & $11^{\circ}$ & University for the Creative Arts & Inglaterra \\
\hline---- & $9^{\circ}$ & $12^{\circ}$ & ---- & Emily Carr University of Art and Design & Canadá \\
\hline---- & ---- & $11^{\circ}$ & $12^{\circ}$ & Berlin Weissensee School of Art & Alemanha \\
\hline---- & $10^{\circ}$ & $13^{\circ}$ & --- & University of Applied Arts Vienna & Áustria \\
\hline $11^{\circ}$ & $14^{\circ}$ & ---- & --- & Pratt Institute & EUA \\
\hline---- & $12^{\circ}$ & $14^{\circ}$ & --- & Pontifical Catholic University of Rio de Janeiro & Brasil \\
\hline---- & ---- & ---- & $7^{\circ}$ & University of Montreal & Canadá \\
\hline---- & --- & ---- & $8^{\circ}$ & Central Saint Martins College of Art \& Design & Inglaterra \\
\hline---- & --- & ---- & 90 & Massachusetts Institute of Technology & EUA \\
\hline---- & ---- & ---- & $10^{\circ}$ & Shenkar College of Engineering, Design and Art & Israel \\
\hline---- & ---- & ---- & $15^{\circ}$ & Rhode Island School of Design (RSID) & EUA \\
\hline---- & $11^{\circ}$ & ---- & ---- & Tomas Bata University in Zlín (TBU) & R. Tcheca \\
\hline
\end{tabular}




\begin{tabular}{|c|c|c|c|c|c|}
\hline \multicolumn{4}{|c|}{$\begin{array}{l}\text { Classificação } \\
\text { conforme o ano }\end{array}$} & \multirow[b]{2}{*}{ Instituição } & \multirow[t]{2}{*}{ 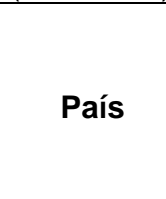 } \\
\hline$\frac{\nabla}{\delta}$ & 웅 & $\frac{0}{\delta}$ & 도 & & \\
\hline---- & $15^{0}$ & ---- & ---- & Darmstadt University of Applied Sciences (H_DA) & Alemanha \\
\hline 90 & ---- & ---- & ---- & Ravensburg University of Cooperative Education & Alemanha \\
\hline $12^{\circ}$ & ---- & ---- & ---- & University of Applied Sciences Northwestern Switzerland & Suíça \\
\hline $13^{\circ}$ & ---- & ---- & ---- & Folkwang University of the Arts & Alemanha \\
\hline $14^{\circ}$ & ---- & ---- & ---- & Coventry University & Inglaterra \\
\hline $15^{\circ}$ & --- & --- & --- & University of Houston & EUA \\
\hline
\end{tabular}

Quadro 2 - Compilação da classificação hierárquica vertical descendente de instituições de ensino superior de Design

Fonte: Red Dot Design (edições 2014 a 2017).

Na elaboração do Quadro 2, utilizamos a compilação da classificação Red Dot Design referente às edições dos anos de 2014 a 2017, prevalecendo, em alguns casos, o sequenciamento da classificação mais recente (2017), quando ocorre, por exemplo, a coincidência na ordenação.

Numa análise preliminar dessa classificação, é possível notar que, entre as 28 instituições que aparecem, 8 são universidades sediadas nos Estados Unidos, 5 na Alemanha e 4 na Inglaterra. Na América Latina, observamos apenas a presença da Pontifícia Universidade Católica do Rio de Janeiro (PUC-Rio), ocupando a $12^{\mathrm{a}} \mathrm{e}$ $14^{\mathrm{a}}$ posições nas edições de 2015 e 2016 , respectivamente. A partir desse espectro, é possível notar um predomínio no ranking de instituições situadas no hemisfério norte-americano e em países de economia mais consolidada na Europa. Assim, sugerem fatores de hegemonia econômica como um reflexo da alocação de universidades dedicadas ao ensino de Design.

Para fins de análise nesta pesquisa, foram realizadas buscas sistemáticas nos sites das instituições classificadas no Red Dot Design, com o intuito de levantar informações referentes aos seguintes aspectos: a) presença de cursos de Design na modalidade a distância; b) nome do curso de Design na modalidade EaD; c) nível de formação; d) duração em meses ou anos; e) carga horária do curso; f) nome do Ambiente Virtual de Aprendizagem utilizado para o ensino de Design; g) qualificação ou nível de formação do curso; h) se há cursos na modalidade a distância que não são de Design. Além disso, também se buscou verificar 
informações adicionais divulgadas nos sites que pudessem contribuir para o desenvolvimento dessa investigação.

As três primeiras instituições do Quadro 2: Umeå Institute of Design; Art Center College of Design e ENSCI - Les Ateliers, localizadas, respectivamente, na Suécia, nos Estados Unidos e na França, não oferecem na modalidade a distância cursos de Design ou outro curso de graduação ou pós-graduação. Já a Universidade Savannah College of Art and Design oferece disciplinas na modalidade a distância utilizando o Ambiente Virtual de Aprendizagem Blackboard. Entre os cursos oferecidos on-line por essa instituição, estão os de Design Gráfico, Design de Interior, Gestão do Design, Design de Animação, entre outros. Tais cursos estão qualificados em nível de formação da graduação à pós-graduação

A Academy of Art University oferece desde 2002 vários cursos on-line utilizando o recurso virtual intitulado "LMS Whiteboard". As qualificações dos cursos on-line vão desde aqueles que antecedem a graduação até os de pósgraduação. As áreas em que a Universidade oferece os cursos são no âmbito tanto do Design como das áreas de Publicidade e Arquitetura, entre outras no universo das Artes. A Instituição denomina o seu ambiente Learning Management System (LMS) - Sistema de Gestão de Aprendizagem (LMS) - “[...] uma ferramenta web centralizada que permite facilmente educandos e educadores interagirem por meio de trocas digitais personalizadas".

A Universidade alocada na sexta posição em nossa compilação da classificação, Middle East Technical University (METU), utiliza o Moodle para a oferta de seus cursos on-line, intitulado “ODTUClass”. Esses cursos são dedicados ao campo da Administração, e não foi identificada nenhuma oferta de formação a distância na área de Design

As instituições California College of the Arts; Burg Giebichenstein University of Art and Design e Royal College of Art (RCA) não ofertam cursos na modalidade a distância. Já a The Oslo School of Architecture and Design (AHO), situada na Noruega, oferece cursos de curta duração e disciplinas eletivas a distância utilizando a plataforma Moodle, cujo endereço do AVA é <http://lms.aho.no/Moodle/>. Tais cursos estão no âmbito do Design.

A University for the Creative Arts utiliza a plataforma Blackboard para a oferta de cursos nas áreas de desenho, fotografia, ilustração, design gráfico, escrita 
criativa, têxteis, escultura, gravura e história da arte. E a instituição Emily Carr University of Art and Design usa a plataforma Moodle.

Em síntese, a partir da análise das 28 instituições, foi possível constatar que uma parte significativa não oferta cursos ou disciplinas de Design na modalidade a distância. Aquelas que ofertam cursos on-line, em geral, utilizam ambientes virtuais Moodle ou Blackboard. Fizemos um quadro-síntese com o objetivo de explicitar quais ambientes virtuais de aprendizagem são utilizados pelas instituições classificadas pelo Red Dot Design (Quadro 3).

\begin{tabular}{|l|c|}
\hline \multicolumn{1}{|c|}{ Instituição } & \multicolumn{1}{|c|}{$\begin{array}{c}\text { AVAs em cursos de } \\
\text { Design }\end{array}$} \\
\hline Savannah College of Art and Design & Blackboard \\
\hline Academy of Art University & Whiteboard \\
\hline Middle East Technical University (METU) & Moodle \\
\hline California College of the Arts & Moodle \\
\hline The Oslo School of Architecture and Design (AHO) & Moodle \\
\hline University for the Creative Arts & Blackboard \\
\hline Emily Carr University of Art and Design & Moodle \\
\hline Central Saint Martins College of Art \& Design & Moodle \\
\hline
\end{tabular}

Quadro 3 - Instituições que oferecem cursos de Design a distância e seu respectivo Ambiente Virtual de Aprendizagem

Fonte: Elaborado pelo autor.

Observamos em nosso levantamento que a instituição Academy of Art University é a única que afirma ter desenvolvido um ambiente próprio, intitulado Whiteboard, para a oferta de disciplinas e cursos no campo do Design. Essa constatação pode ser observada na apresentação e definição do ambiente, disponível no website da Universidade:

Desenvolvemos nosso próprio Sistema de Gerenciamento de Aprendizagem personalizado - uma ferramenta web que permite aos estudantes e professores interagirem e trocarem facilmente recursos digitais. $\mathrm{O}$ recurso Whiteboard permite aos tutores agendar a entrega de trabalhos e fornecer feedback detalhado, incluindo comentários de áudio. O Sistema de Gerenciamento de Aprendizagem Whiteboard também serve como um canal centralizado para notícias e atualizações de classe, informações de notas, suporte, agendamento de sessões de tutoria individuais e uma série de outros recursos adaptados para tornar sua educação online tão rica quanto possível. (Academyart, 2017) 
No Quadro 4, temos a exposição dos Ambientes Virtuais de Aprendizagem utilizados por instituições qualificadas pelo ranking Red Dot Design, 2014 a 2017. No entanto, os AVAs são usados em cursos e disciplinas fora da área do Design.

\begin{tabular}{|l|c|}
\hline \multicolumn{1}{|c|}{ Instituição } & $\begin{array}{c}\text { AVAs em outros cursos } \\
\text { (Não de Design) }\end{array}$ \\
\hline Umeå University & Moodle e Cambro \\
\hline Savannah College of Art and Design & Blackboard \\
\hline Academy of Art University & Whiteboard \\
\hline Middle East Technical University (METU) & Moodle \\
\hline California College of the Arts & Moodle \\
\hline The Oslo School of Architecture and Design (AHO) & Moodle \\
\hline Pontifical Catholic University of Rio de Janeiro & Moodle \\
\hline University of Montreal & Moodle \\
\hline Central Saint Martins College of Art \& Design & Stellar / EDX \\
\hline Massachusetts Institute of Technology & Moodle \\
\hline Rhode Island School of Design (RSID) & Moodle \\
\hline Tomas Bata University in Zlín (TBU) & Moodle \\
\hline Darmstadt University of Applied Sciences (H_DA) & Moodle \\
\hline University of Applied Sciences Northwestern Switzerland & Moodle \\
\hline Folkwang University of the Arts & Moodle \\
\hline Coventry University & Blackboard \\
\hline University of Houston & Cursos a dinncia \\
\hline
\end{tabular}

Quadro 4 - Instituições no Red Dot Design (2014 a 2017) que oferecem cursos a distância fora da área do Design e seu respectivo Ambiente Virtual de Aprendizagem Fonte: Elaborado pelo autor.

O Quadro 4 demonstra a prevalência do ambiente Moodle na oferta de cursos a distância, fora da área do Design, assim como constatado no Quadro 3 na oferta de cursos de Design. No entanto, diante dessa constatação, também se observa que a Instituição Umeå University utiliza, além do Moodle, o Ambiente Virtual de Aprendizagem intitulado Cambro, desenvolvido pela Universidade. Também desperta nossa atenção o fato de a Instituição Middle East Technical University (METU) construir um ambiente próprio a partir da configuração e customização estrutural da plataforma Moodle, intitulando-o ODTUClass. 


\section{2 Ambientes Virtuais de Aprendizagem e a classificação QS World University}

Após o levantamento e análise dos ambientes utilizados pelas instituições classificadas pelo Red Dot Design, passamos a usar outra classificação internacional para verificar um número maior de universidades. Adotamos o ranking QS World University para verificar os AVAs utilizados por instituições de ensino superior mais bem posicionadas na relação.

O Qs World University Rankings são classificações universitárias publicadas anualmente sob a coordenação da empresa de consultoria Quacquarelli Symonds (QS), sediada na Inglaterra.

Para esta pesquisa, utilizamos uma compilação de classificação das edições dos anos de 2014 a 2018. A partir dessa compilação, elaboramos uma relação com 40 instituições, conforme segue:

Massachusetts Institute of Technology (MIT) / Stanford University / Harvard University / California Institute of Technology (Caltech) / University of Cambridge / University of Oxford / UCL (University College London) / Imperial College London / University of Chicago / ETH Zurich / Nanyang Technological University (NTU) / Ecole Polytechnique Fédérale de Lausanne / Princeton University / Cornell University / National University of Singapore (NUS) / Yale University / Johns Hopkins University / Columbia University / University of Pennsylvania / Australian National University / University of Michigan / Duke University / University of Edinburgh / King's College London (KCL) / University of Hong Kong / University of California, Los Angeles (UCLA) / University of Tokyo / Northwestern University / Hong Kong University of Science and Technology / University of Toronto / McGill University / University of Manchester / Kyoto University / Seoul National University / University of California, Berkeley (UCB) / University of Melbourne / Ecole normale supérieure, Paris / University of Bristol / Ecole Polytechnique / University of Sydney.

Notou-se predominantemente que os cursos que utilizam AVAs são aqueles NÃO ligados ao ensino de Design. A análise também revelou, dominantemente, a evidência de Ambientes Virtuais de Aprendizagem caracterizados pelo alinhamento aos cursos reconhecidos como massivos, denominados MOOC (Cursos Online Abertos e Massivos /Massive Open Online Course). Os MOOCs têm como foco o 
livre acesso ao conhecimento e possuem a intenção de atingir um público amplo de educandos. Além disso, tais cursos priorizam objetivos quantitativos de formação inicial ou continuada.

Por meio deste levantamento foi possível observar que 31 instituições internacionais de ensino superior, de um total de 40, ofertam cursos de Design. Essa parcela corresponde a $77 \%$ do total das instituições selecionadas conforme expõe o Gráfico 2:

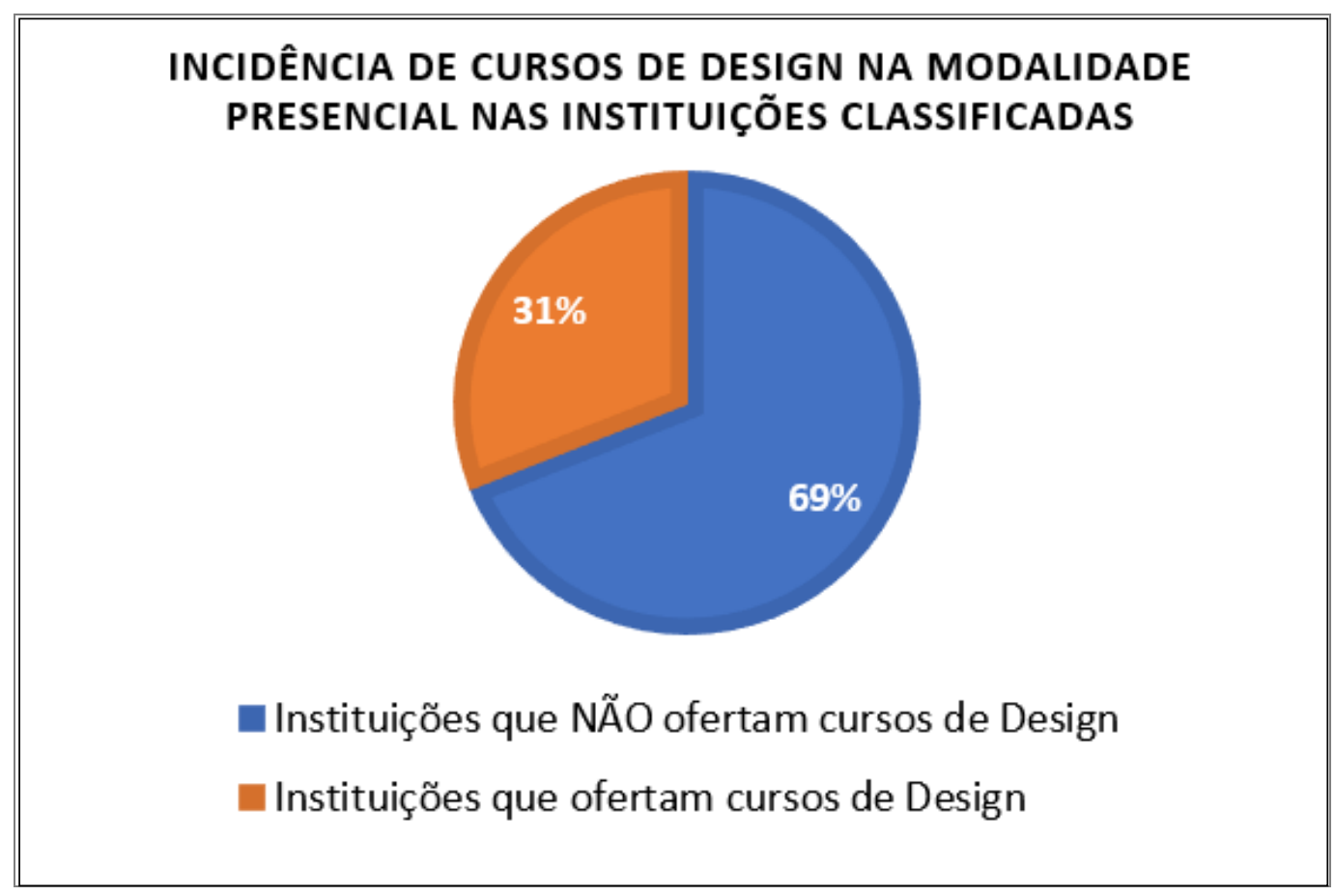

Gráfico 2 - Gráfico setorial baseado nos dados da pesquisa Fonte: Dados da Pesquisa.

A partir do levantamento e da análise das 40 instituições, revelou-se que em apenas quatro situações são utilizados Ambientes Virtuais de Aprendizagem em cursos de Design nas instituições classificadas pelo QS World University. Os ambientes virtuais utilizados são: EDX, ICE VLE, Coursera e Canvas para o ensino de Design na modalidade a distância, conforme aponta o Gráfico 3: 


\section{AMBIENTES VIRTUAIS DE APRENDIZAGEM UTILIZADOS EM CURSOS DE DESIGN NA MODALIDADE À DISTÂNCIA NAS INSTITUIÇÕES SELECIONADAS}

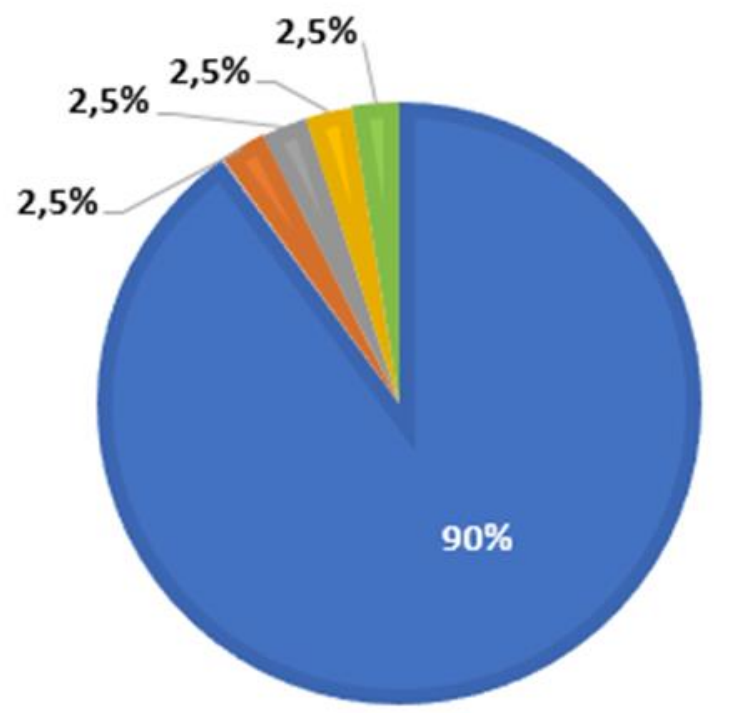

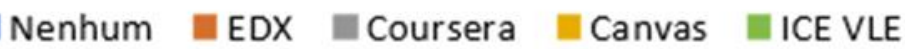

Gráfico 3 - Gráfico setorial baseado nos dados da pesquisa Fonte: Dados da Pesquisa.

Por meio dessa análise também foi possível obter informações no tocante à apropriação de Ambientes Virtuais de Aprendizagem pelas instituições selecionadas na oferta de outros cursos, não sendo, neste caso, cursos de Design. Têm-se um quantitativo de 32 adesões em contraposição a apenas 8 que ainda não utilizam nenhum tipo de AVAs. Nas instituições que utilizam os AVAS em suas modalidades de ensino, o recurso que se revela mais comumente utilizado é o Coursera, com 33,3\% de adesão, seguido pelo EDX, com 20,5\% de uso. Já os ambientes Blackboard e Moodle aparecem na quarta e terceira classificação com $17,8 \%$ e $12,8 \%$ de adesão, respectivamente.

Os resultados alcançados por meio deste estudo revelam que uma parcela significativa das instituições de ensino superior classificadas pelo QS World University opta por utilizar AVAs com características do formato de cursos abertos e massivos, os chamados Massive Open Online Course (MOOC), conforme Gráfico 4: 


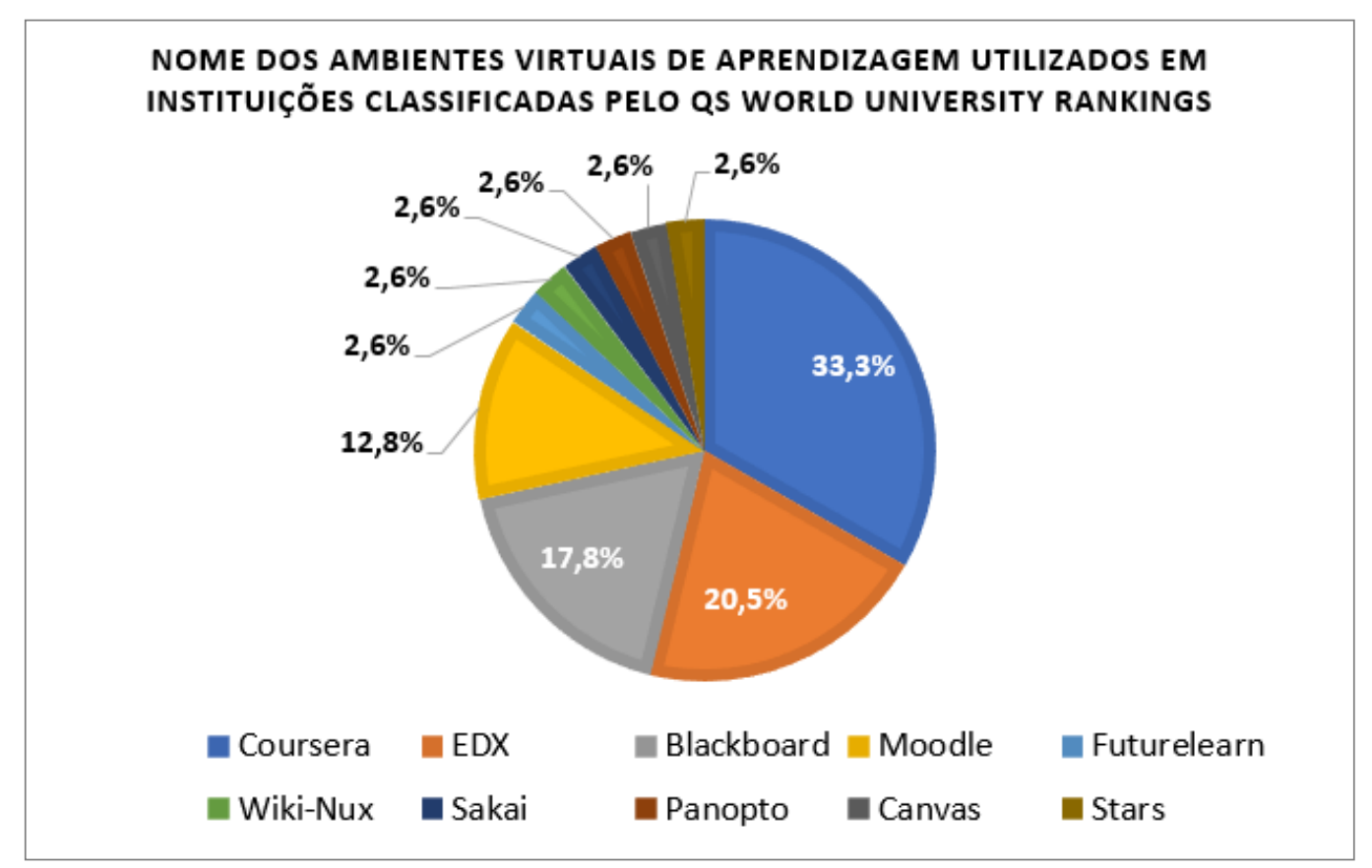

Gráfico 4 - Gráfico setorial baseado nos dados da pesquisa Fonte: Dados da Pesquisa.

A partir deste levantamento e exame das instituições de ensino, foi possível considerar o predomínio da utilização padronizada de AVAs construídos para o uso comum em cursos na modalidade a distância, revelando-se um número reduzido de iniciativas dedicadas na construção de novos ambientes em suas práticas educativas. Somada a essa realidade tem-se a constatação de que, embora os cursos de Design estejam presentes na maioria das instituições, são poucas propostas de confluências dos campos do Design e da Educação a Distância no âmbito da construção de AVAs.

Considerando o levantamento e a análise das informações até aqui, é possível constatar a escassez de novos Ambientes Virtuais de Aprendizagem em instituições classificadas pelo Red Dot Design nas edições de 2014 a 2016 e pelo QS World University nas edições de 2014 a 2018.

Na próxima subseção deste capítulo, tem-se o intento de apresentar e analisar um panorama dos Ambientes Virtuais de Aprendizagem mais utilizados na atualidade, com o objetivo de também verificar a incidência de novos AVAs. Observa-se um contexto de ampliação de tecnologias digitais de informação e comunicação com a possibilidade de serem utilizadas na construção de recursos digitais e de AVAs. 


\section{3 \\ Ambientes Virtuais de Aprendizagem mais utilizados internacionalmente}

$\mathrm{Na}$ atualidade, o desenvolvimento e a expansão das tecnologias digitais de informação e comunicação têm propiciado a construção de diferentes recursos digitais educacionais, e, de modo especial, possibilitado o surgimento de novos Ambientes Virtuais de Aprendizagem. Como exemplo disso, além dos recursos EDX e Coursera criados no ano de 2012, há outras iniciativas, como o ambiente Edmodo, criado em 2007, que vem despontando no cenário educacional e ampliando o número de usuários mundialmente.

Diferentes proposições têm surgido de construção de ambientes dedicados tanto à educação a Distância quanto á aprendizagem semipresencial, também conhecida como modalidade híbrida, numa aproximação entre a educação presencial e a distância.

A modalidade de ensino híbrido tem origem na expressão inglesa "Blended Learning", comumente compreendido também como ensino semipresencial. A palavra "Blend" significa combinar, misturar. E, assim, esse formato de ensino preconiza a combinação entre a educação presencial com a educação a distância.

Assistimos na atualidade ao surgimento de diferentes AVAs que são utilizados não somente na Educação a Distância; percebemos iniciativas que tendem a utilizar os AVAs como um recurso de apoio ao ensino presencial.

Sendo assim, neste estudo, buscou-se também identificar e analisar os AVAs mais utilizados no ensino a distância, a partir de um levantamento de ambientes mais utilizados internacionalmente. A classificação apresentada a seguir assumiu os critérios de categorização promovida pela equipe do Capterra. O Capterra é um diretório on-line que classifica diferentes softwares adotando critérios como quantidade de usuários, vínculo em redes sociais, números de consumidores, entre outros.

A Figura 1 demonstra o quantitativo de usuários em diferentes Ambientes Virtuais de Aprendizagem, contabilizados no ano de 2016. 
Ambientes Virtuais de Aprendizagem mais utilizados internacionalmente.

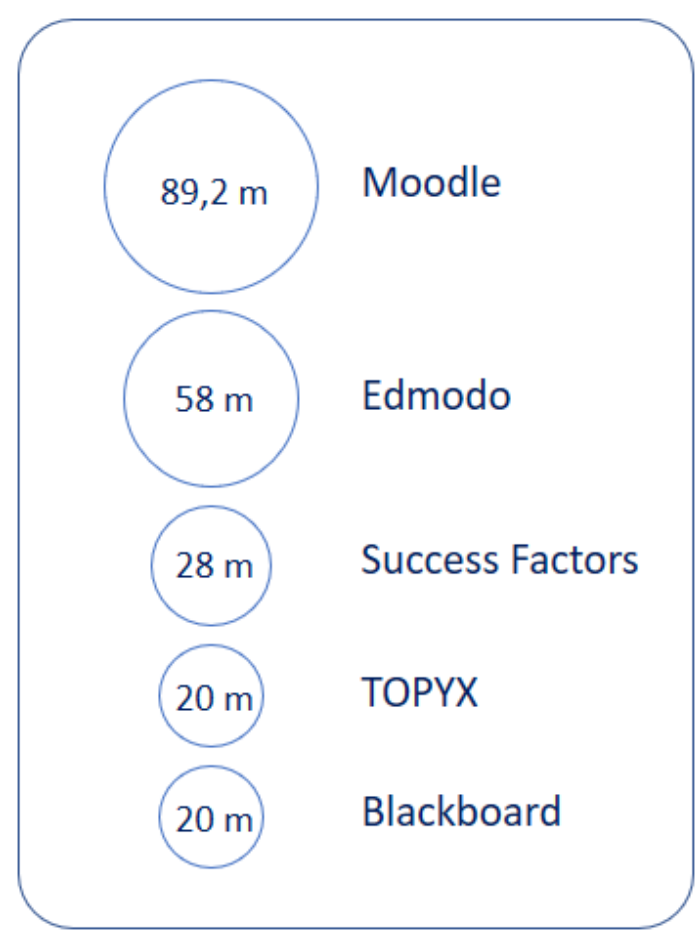

Figura 1 - Gráfico setorial com nomes dos Ambientes Virtuais de Aprendizagem mais utilizados internacionalmente com quantitativo de usuários Fonte: Capterra (2016)

Nota-se a partir desse panorama que os Ambientes Virtuais de Aprendizagem mais utilizados em propostas de Educação a Distância são, respectivamente, Moodle, Edmodo, Success Factors, TOPYX e Blackboard. Os números demonstram que os ambientes Moodle e Edmodo possuem juntos uma quantidade de usuários superior ao dobro das três plataformas na sequência.

A Figura 1 também revela a presença de um número expressivo de usuários diante das diferentes propostas de AVAs já construídos.

\section{4}

\section{Análise e discussão dos Ambientes Virtuais de Aprendizagem mais usados internacionalmente}

A partir do levantamento de AVAs utilizados, é possível tecer algumas reflexões no que se refere às características e possibilidades de tais recursos. É possível, por exemplo, reconhecer elementos típicos nos ambientes virtuais de modo a identificar aspectos positivos disponíveis nos AVAs. Observam-se os ambientes Moodle, Blackboard, Coursera e EDX como os que mais se evidenciam 
em instituições voltadas para o Design, e o Edmodo como um dos AVAs mais utilizados internacionalmente, possibilitando, assim, estabelecer algumas reflexões.

Os ambientes Moodle e Blackboard são os AVAs que mais apresentam funcionalidades voltadas a situações de aprendizagem numa concepção construtivista/interacionista. Tal constatação se deve pela multiplicidade de recursos disponíveis e pela variabilidade e flexibilidade na configuração do layout desses AVAs. Tais ambientes oferecem a possibilidade de organização e customização do espaço de interação, tanto na inserção de recursos e funcionalidades quanto na colocação das atividades dos cursos.

Já os ambientes Edmodo, EDX e Coursera são propostas mais rígidas no que se refere à configuração do layout. Contudo, o Edmodo destaca-se dos demais por dispor de uma interface gráfica simples que propicia certa facilidade para aprender a utilizá-lo de modo prático para tutores e educandos-usuários. De modo particular, no Edmodo há uma facilidade em utilizá-lo por este apresentar uma interface similar àquelas das redes sociais digitais. $\mathrm{O}$ ambiente é análogo às redes sociais e dispõe de um mural de postagens num formato de Linha do Tempo (Timeline), favorecendo ações de compartilhamento, comentários e curtidas das publicações de tutores e educandos.

\section{5 \\ Considerações parciais dos Ambientes Virtuais de Aprendizagem}

Neste capítulo foi possível constatar que as instituições classificadas pelo Red Dot Design e pelo QS World University optam pelo uso de Ambientes Virtuais de Aprendizagem comumente reconhecidos, revelando uma escassez de alternativas na produção e apropriação de novos AVAs. O levantamento também pôde demonstrar que as opções mais adotadas pelas instituições envolvidas com o ensino de Design são, respectivamente, os ambientes Moodle e Blackboard, na classificação Red Dot Design; e os ambientes EDX e Coursera, na classificação QS World University, evidenciando, assim, uma escassez de construções de novos AVAs por instituições que ofertam cursos de Design.

Os ambientes EDX e Coursera, embora apresentem características de democratização do acesso ao conhecimento, também demonstram um viés caracterizado pela concepção de formação massiva, seguindo critérios com níveis 
de configuração nos ambientes de modo restrito. Já os ambientes Moodle, Blackboard, por apresentarem uma grande diversidade de funções, tendem a demandar do usuário um aprendizado mais detalhado para seu uso.

Foi possível identificar a partir dessa análise do panorama atual um grau de isolamento entre o Design e a Educação a Distância na proposição da diversidade de construção de novos AVAs.

O estudo também revelou ser um ponto positivo os AVAs apresentarem certa flexibilidade na configuração de sua interface, permitindo aos usuários adequá-los às suas necessidades, como no caso do Moodle e Blackboard. Além disso, considera-se relevante disponibilizar uma quantidade moderada de funcionalidades e recursos educativos, com o objetivo de possibilitar uma facilidade na configuração e no uso.

Também é adequado que o ambiente apresente certa simplicidade de utilização com um layout simples, amigável, como no exemplo do Edmodo. Defende-se a aproximação interdisciplinar entre os campos do Design e da EaD com vistas a otimizar estratégias de concepção e produção de AVAs favoráveis aos processos de ensino-aprendizagem.

Dessa maneira, este capítulo teve como objetivo apresentar, através de critérios de ranking (classificação), um panorama dos AVAs utilizados em instituições internacionais dedicadas ao ensino do Design. Supõe-se que instituições envolvidas com o ensino de Design têm a oportunidade de dedicar-se amplamente na produção de AVAs seguindo critérios otimizados de interação entre educandos, educadores e AVAs. Contudo, o levantamento revela, de modo geral, que tais instituições optam pelo uso de recursos comumente reconhecidos, revelando uma escassez de alternativas na produção e apropriação de novos AVAs. O levantamento também demonstra que as opções mais adotadas pelas instituições envolvidas com o ensino de Design são, respectivamente, os ambientes Coursera, EDX e Blackboard e Moodle. Esses ambientes, embora apresentem características de democratização e popularização do acesso ao conhecimento e à formação superior, também demonstram um viés caracterizado pela formação massiva, seguindo critérios com níveis de configuração dos AVAs restritos. 


\section{4 \\ O designer instrucional e suas contribuições na construção de Ambientes Virtuais de Aprendizagem}

O presente capítulo tem como objetivo apresentar as contribuições do profissional designer instrucional na construção de Ambientes Virtuais de Aprendizagem. Os profissionais identificados como designers instrucionais têm-se dedicado, comumente, à produção de diferentes recursos e materiais utilizados em processos de ensino-aprendizagem na modalidade a distância. Analisamos neste capítulo as impressões e os relatos de alguns designers instrucionais no que se refere à construção de Ambientes Virtuais de Aprendizagem. São apresentados, analisados e discutidos os seguintes aspectos: a) perfil; b) formação acadêmica e c) proposições de técnicas e métodos adotados por esses profissionais na construção de AVAs.

Nas formulações de Filatro (2004), o profissional designer instrucional é reconhecido como:

um profissional que realiza uma ação intencional e sistemática de ensino, que envolve o planejamento, o desenvolvimento e a utilização de métodos, técnicas, atividades, materiais, eventos e produtos educacionais em situações didáticas específicas, a fim de facilitar a aprendizagem humana a partir dos princípios de aprendizagem e instrução conhecidos. (2004, p. 21)

Este capítulo está em consonância com o terceiro objetivo específico desta pesquisa: Sintetizar as concepções de designers instrucionais, com vistas a tratar o potencial de significação e interação em AVAs. De modo especial, também serão tratados aqui a identificação das técnicas e métodos utilizados por esses designers instrucionais, os quais serão abordados na subseção 4.3 deste capítulo.

No processo de coleta de informações para a consolidação deste capítulo, foram aplicados questionários com questões abertas e fechadas direcionadas a designers instrucionais que trabalham ou já trabalharam na Educação a Distância e, especialmente, com a construção de ambientes virtuais. O intento é aprofundar na 
coleta de impressões e concepções dos profissionais, além da captação de elementos acerca dos métodos e técnicas utilizados na construção de AVAs. Considera-se a área de Design Instrucional como uma atividade aparentemente próxima à relação entre os campos do Design e da Educação a Distância. Teve-se como mote a análise da atuação dos designers instrucionais e as possibilidades de construção de AVAs a partir da convergência os referidos campos.

No que se refere ao uso de questionários na realização de pesquisas, a definição de Marconi \& Lakatos (2003) elucida as características presentes nesse tipo de instrumento de coleta de dados: trata-se de um instrumento "constituído por uma série ordenada de perguntas, que devem ser respondidas por escrito e sem a presença do entrevistador" (Marconi; Lakatos, 2003, p. 201). No processo de construção de questionários, é necessário considerar aspectos relevantes com o objetivo de aumentar a eficácia e a qualidade dos dados coletados. Conforme Marconi \& Lakatos (Ibid., p. 202). “O processo de elaboração é longo e complexo: exige cuidado na seleção das questões, levando em consideração a sua importância, isto é, se oferece condições para a obtenção de informações válidas". Assim, as questões a serem tratadas necessitam estar condizentes com os objetivos da pesquisa.

Quanto à interpretação dos dados coletados, utilizou-se nesta pesquisa a técnica de análise de conteúdo para as perguntas abertas do questionário. Já para as questões fechadas, realizou-se uma análise quantitativa e a construção de gráficos e tabelas, de modo a facilitar a compreensão das informações. A análise de conteúdo teve como um dos precursores o cientista político Harold Dwight Lasswell, que utilizou essa técnica na década de 1915. Entretanto, a análise de conteúdo alcançou popularidade a partir de Bardin (2011).

Para Bardin (Ibid., p. 47), a técnica de análise de conteúdo consiste:

[...] um conjunto de técnicas de análise das comunicações visando a obter, por procedimentos sistemáticos e objetivos de descrição do conteúdo das mensagens, indicadores (quantitativos ou não) que permitam a inferência de conhecimentos relativos às condições de produção/recepção (variáveis inferidas) destas mensagens.

Com o objetivo de analisar as práticas de Design Instrucional e reconhecer os métodos e técnicas utilizados na produção de AVAs, será apresentada a seguir a análise dos dados gerados pela pesquisa. São expostas e discutidas informações 
aprofundadas referentes a quatro grandes categorias: a) o perfil e o lugar do designer instrucional na construção de Ambientes Virtuais de Aprendizagem; b) as ações realizadas pelo profissional designer instrucional relacionadas à construção de material impresso, recursos digitais e/ou Ambientes Virtuais de Aprendizagem; c) as metodologias utilizadas nas produções de recursos (como produzem e quais ferramentas, técnicas ou teorias utilizadas) e d) as perspectivas de ações e produções pelo profissional designer instrucional (melhorias $d a$ atuação, avaliação das ações e novos rumos).

A partir da próxima seção, iniciaremos a exposição do que foi encontrado na pesquisa a partir da aplicação de questionários direcionados a 27 designers instrucionais. Começaremos com a apresentação do perfil e o lugar desses profissionais na construção de Ambientes Virtuais de Aprendizagem.

Os participantes foram informados antecipadamente dos objetivos da pesquisa e concordaram em participar, desde que fossem mantidos no anonimato. (Apêndice A). Para tanto, para fins de sigilo, os 27 designers instrucionais serão denominados "respondentes" e codificados com a letra "R". Sequencialmente, temos aqui o respondente inicial denominado $\mathrm{R} 1$ e o último respondente designado R27.

\section{1 Perfil e lugar do designer instrucional na construção de Ambientes Virtuais de Aprendizagem}

O intento desta seção se direciona à compreensão de aspectos ligados à formação inicial e continuada dos profissionais designers instrucionais. Tem-se como um dos objetivos verificar a concepção desses profissionais em relação às ações realizadas na construção de AVAs.

Neste sentido, buscou-se realizar um levantamento de informações, a partir da aplicação de questionários com perguntas abertas e fechadas direcionados a designers instrucionais que trabalham ou já trabalharam na construção de AVAs (Apêndice B). O levantamento conseguiu registrar 27 respondentes formados em diferentes instituições de ensino superior localizadas em distintas regiões do Brasil. No que se refere à atuação desses 27 respondentes, constam 18 que trabalham como designer instrucional e 9 que não trabalham atualmente, mas já trabalharam. O Gráfico 5 apresenta a faixa etária dos pesquisados. 


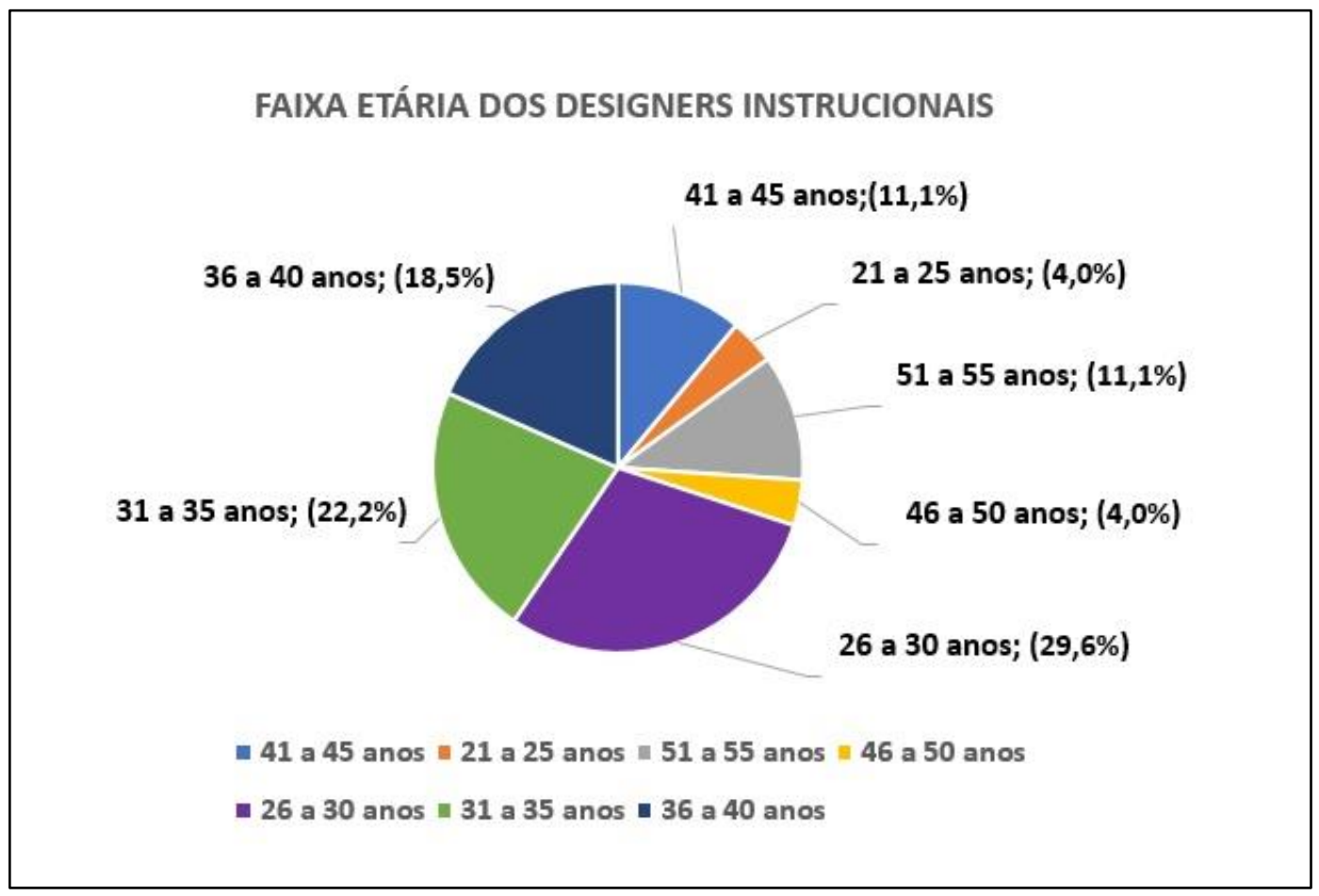

Gráfico 5 - Faixa etária dos designers instrucionais Fonte: Dados da Pesquisa.

Ao examinar as respostas que surgiram, foi possível identificar que a maioria dos pesquisados possui idade entre 26 a 35 anos. Essa informação demonstra que esses profissionais se encontram numa faixa etária equivalente ao período hábil de já terem cursado uma graduação e uma pós-graduação Lato Sensu ou Stricto Sensu. Essa informação será confirmada a seguir, na seção que expõe a titulação dos pesquisados, que, de modo geral, possuem no mínimo o curso de pós-graduação Lato Sensu.

A partir da análise dos dados obtidos, buscamos verificar a formação inicial dos profissionais, a fim de levantar o quantitativo de bacharéis e licenciados, além das suas respectivas áreas de formação. Um dos designers instrucionais pesquisados possui duas graduações: uma em licenciatura e outra em bacharelado. Entre os demais pesquisados, 14 concluíram cursos de licenciatura e 12 concluíram cursos de bacharelado em diferentes áreas. Desses últimos, os bacharéis, apenas três possuem a formação inicial específica em Design, conforme Os Quadros 5, 6 e 7. 


\begin{tabular}{|c|c|}
\hline Licenciatura & Instituição de Ensino Superior no qual cursou a Licenciatura \\
\hline Letras & Universidade do Estado do Rio de Janeiro \\
\hline Pedagogia & Universidade do Estado de Minas Gerais \\
\hline Pedagogia & Universidade do Estado de Minas Gerais \\
\hline Pedagogia & Universidade Federal de Minas Gerais \\
\hline Pedagogia & Universidade Federal de Minas Gerais \\
\hline Matemática & Universidade Camilo Castelo Branco \\
\hline Pedagogia & Centro Universitário São Camilo \\
\hline Pedagogia & Universidade Metodista de São Paulo \\
\hline Pedagogia & Universidade do Estado de Minas Gerais \\
\hline Pedagogia & Universidade do Estado de Minas Gerais \\
\hline Pedagogia & Centro Universitário da Cidade do Rio de Janeiro \\
\hline Pedagogia & Universidade do Estado de Minas Gerais \\
\hline Biologia & Universidade Estadual do Norte Fluminense \\
\hline Letras & Universidade de São Paulo \\
\hline
\end{tabular}

\begin{tabular}{|l|l|}
\hline \multicolumn{1}{|c|}{ Bacharelado } & \multicolumn{1}{c|}{$\begin{array}{c}\text { Instituição de Ensino Superior no qual cursou o } \\
\text { Bacharelado }\end{array}$} \\
\hline Psicologia & Pontifícia Universidade Católica do Rio de Janeiro \\
\hline Comunicação Social & Faculdades Integradas Pitágoras de Montes Claros \\
\hline Design Gráfico & Universidade do Estado de Minas Gerais \\
\hline Ciência da Computação & Universidade Estadual de Montes Claros \\
\hline Odontologia & Universidade do Oeste Paulista \\
\hline Ciência da Informação & Pontifícia Universidade Católica de São Paulo \\
\hline Comunicação Social & Pontifícia Universidade Católica do Rio de Janeiro \\
\hline Engenharia de Computação & Centro Universitário Fundação Santo André \\
\hline $\begin{array}{l}\text { Desenho Industrial / } \\
\text { Comunicação Visual }\end{array}$ & Pontifícia Universidade Católica do Rio de Janeiro \\
\hline Ciência Política & Universidade de Brasília \\
\hline Arquitetura & Universidade Federal do Rio de Janeiro \\
\hline Design Gráfico & Faculdade Estácio de Sá \\
\hline
\end{tabular}

Quadro 6 - Formação inicial e instituição de ensino dos pesquisados (Bacharelado) Fonte: Dados da Pesquisa.

\begin{tabular}{|c|c|}
\hline $\begin{array}{c}\text { Licenciatura e o } \\
\text { Bacharelado }\end{array}$ & $\begin{array}{c}\text { Instituição de Ensino Superior no qual cursou a } \\
\text { Licenciatura e o Bacharelado }\end{array}$ \\
\hline $\begin{array}{c}\text { Ciências da Computação / } \\
\text { Pedagogia }\end{array}$ & $\begin{array}{c}\text { Universidade do Vale do Paraíba e Centro Universitário } \\
\text { Claretiano }\end{array}$ \\
\hline
\end{tabular}

Quadro 7 - Formação inicial e instituição de ensino dos pesquisados (Licenciatura e Bacharelado)

Fonte: Dados da Pesquisa. 
A constatação de um número elevado de licenciados e bacharéis com formações distintas e alheias ao campo específico do Design revela um distanciamento entre o Design e a formação inicial desses profissionais. Essencialmente, os designers instrucionais não são formados em Design. Sendo assim, têm-se indícios de que a possibilidade de encontrar práticas balizadas em técnicas e métodos típicos do Design é algo escasso na construção de materiais e ambientes para a Educação a Distância.

No que se refere à formação continuada dos pesquisados, constatou-se que a maioria $(40,7 \%)$ possui curso de Especialização Lato Sensu; outros 25,9\% são mestres; $11,1 \%$ cursam doutorado; $8 \%$ cursam mestrado; $8 \%$ possuem o título de doutor, e $8 \%$ dos pesquisados possuem o curso de graduação. Aqueles com apenas o curso de graduação, são assim caracterizados: um é bacharel em Psicologia e trabalha como designer instrucional há 5 anos e o outro é designer gráfico e trabalha como designer instrucional há 10 anos. O Gráfico 6 apresenta a síntese da titulação dos pesquisados.

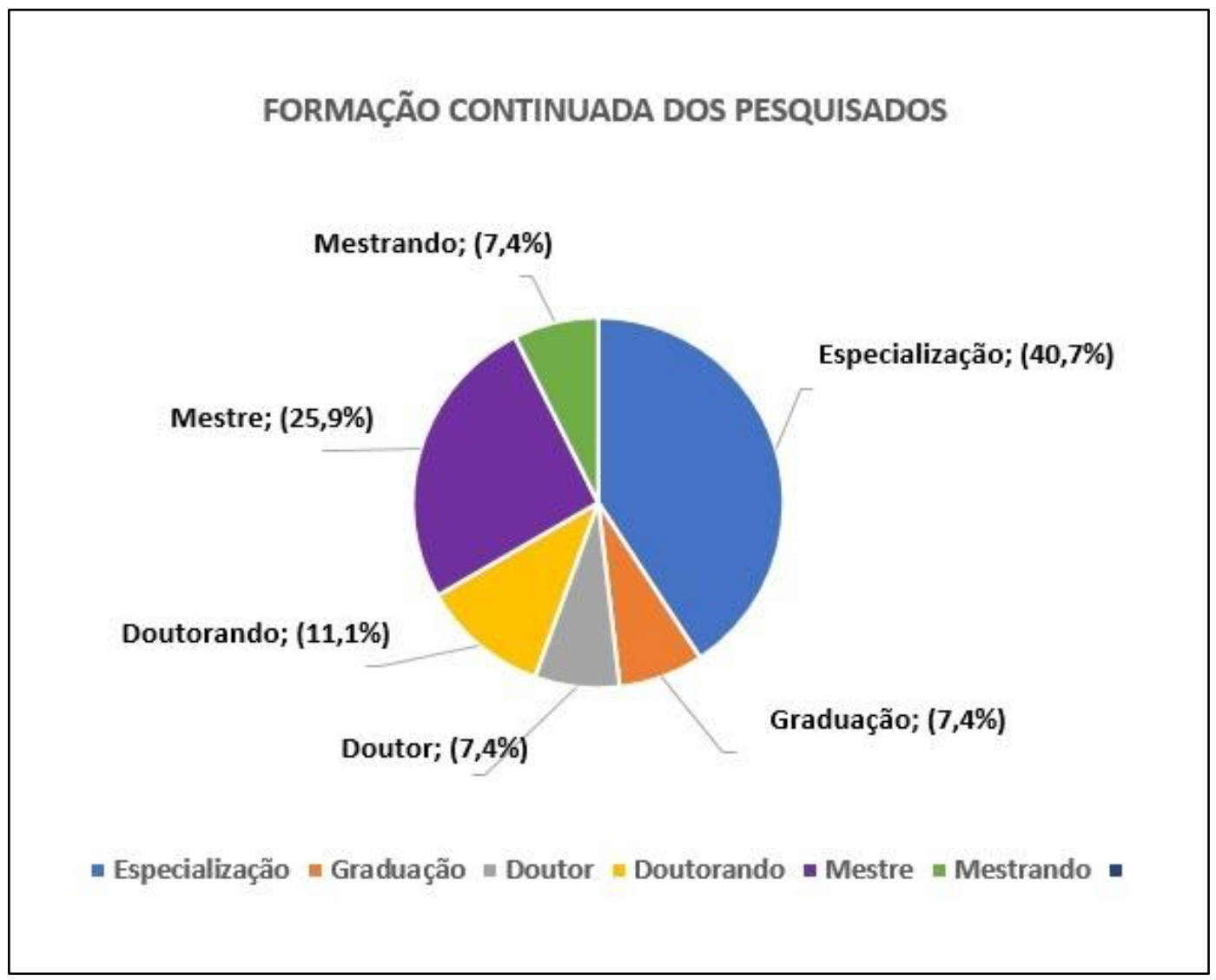

Gráfico 6 - Formação continuada dos pesquisados Fonte: Dados da Pesquisa. 
A análise dessas informações aponta que a titulação dos designers instrucionais pesquisados apresenta no mínimo o curso de Pós-graduação Lato Sensu. Tais profissionais investigados mostram-se dedicados à formação continuada, tanto no curso de mestrado quanto no curso de doutorado. É possível considerar que a dedicação à formação continuada dos designers instrucionais possa estar relacionada à busca por superar os limites e as restrições em sua formação inicial, demandada em tal atuação. O Gráfico 7 demonstra a síntese da formação continuada dos pesquisados.

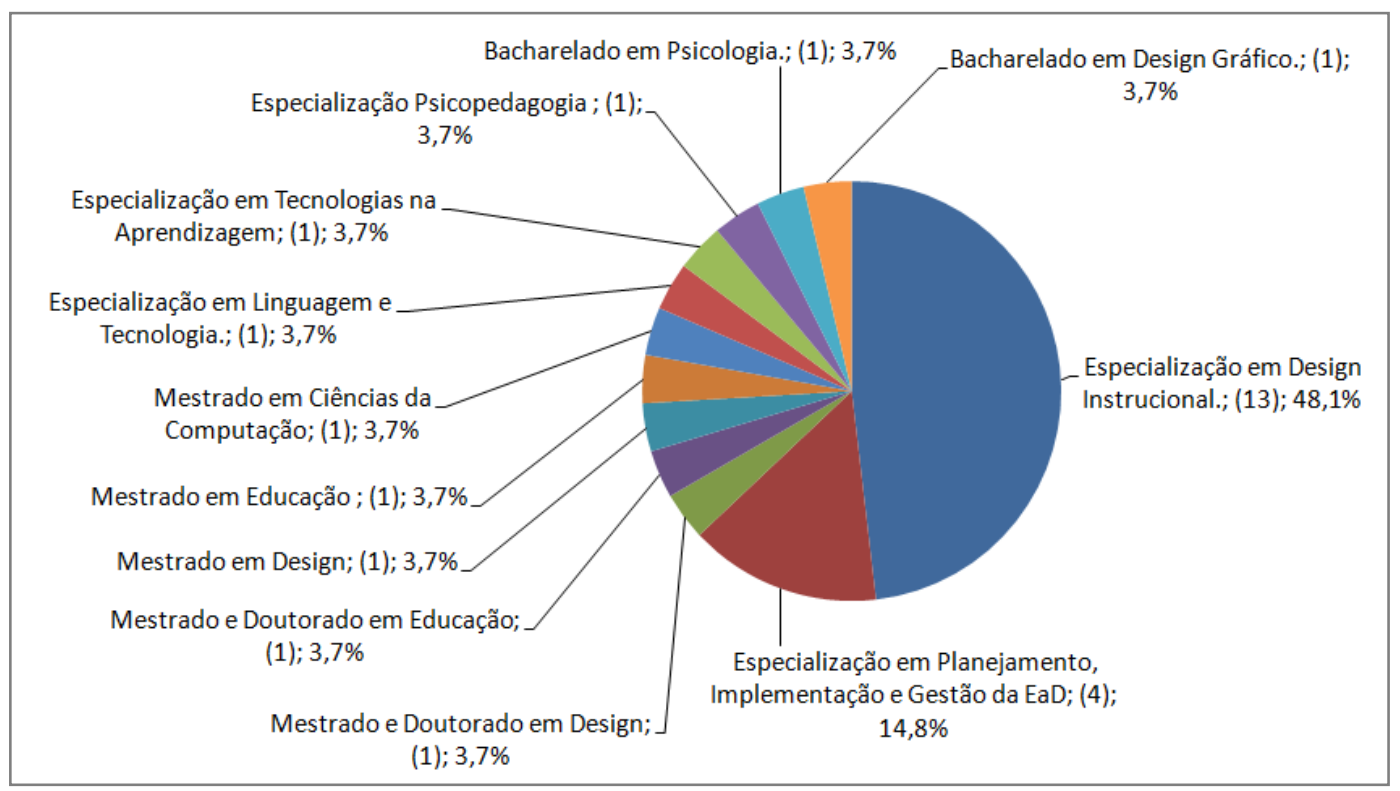

Gráfico 7 - Formação continuada dos designers instrucionais pesquisados Fonte: Dados da Pesquisa.

O Gráfico 7 expõe a pluralidade na formação dos profissionais designers instrucionais pesquisados. Muitos deles - 13 entre os 27, o que corresponde a 48,1\% do total - cursaram a Pós-graduação Lato Sensu Especialização em Design Instrucional. Dos 13 designers instrucionais, 3 possuem outra formação complementar: um possui o curso de Especialização Lato Sensu em Planejamento, Implementação e Gestão da EaD, somado aos cursos de Mestrado e Doutorado em Educação. Já outro cursou o Mestrado em Design, e, finalmente, o terceiro cursou Mestrado em Biociências e Biotecnologia.

Com o intuito de compreender o lugar do designer instrucional na construção de Ambientes Virtuais de Aprendizagem e de outros recursos digitais, materiais educativos, a pesquisa buscou também levantar a concepção desses profissionais 
pelo viés das ações por eles realizadas. A utilização do termo "lugar" nesta pesquisa se deve aos estudos realizados junto aos pesquisadores integrantes do Laboratório Linguagem, Interação e Construção de sentidos/Design - LINC Design da Pontifícia Universidade Católica do Rio de Janeiro, do qual faz parte o autor desta pesquisa.

Conforme explicita Dias (2013, p.21):

Acreditamos que pensar no "lugar" dos sujeitos implica em pensar na sua posição, no seu envolvimento com o espaço que ocupam, com ou sem fronteiras definidas; na sua posição em relação aos objetos e demais sujeitos com que se relacionam; no seu olhar a partir dessa posição; na direção em que se colocam; no seu papel ou na importância que assumem em relação a outros.

Neste sentido, para se compreender os "Lugares" dos designers instrucionais na construção de AVAs, foram extraídos os conteúdos identificados nas respostas (Tabela 1), de forma a perceber possíveis argumentos diretamente ligados à construção de tais ambientes.

Posteriormente à leitura flutuante das respostas à questão, extraíram-se as unidades de registro e foram definidas categorias para análise, de modo a possibilitar algumas inferências.

Pergunta número 10 (aberta): Quais os "Lugares" dos designers instrucionais na construção de Ambientes Virtuais de Aprendizagem?

\begin{tabular}{lccc}
\hline \multicolumn{1}{c|}{ Conteúdos identificados nas respostas: } & Quantidade & Percentual \\
\hline Planejar e modelar estratégias pedagógicas de interação. & 11 & $41 \%$ \\
Organizar e tratar conteúdos. & 04 & $15 \%$ \\
Desenhar e desenvolver recursos e materiais. & 03 & $11 \%$ \\
Planejar e estruturar cursos. & 03 & $11 \%$ \\
Adaptar e organizar AVAs. & 03 & $11 \%$ \\
Dar suporte e colaborar com a equipe pedagógica. & 02 & $7 \%$ \\
\hline
\end{tabular}

Tabela 1 - Análise de conteúdo dos questionários

Fonte: Dados da Pesquisa.

É possível reconhecer, a partir da compilação das expressões dos pesquisados, o predomínio de uma concepção na qual o designer instrucional é um profissional que realiza ações relacionadas ao planejamento didático-pedagógico e desenvolvimento de estratégias de ensino-aprendizagem. Esses argumentos se apresentam predominantemente nas respostas. 
Outros respondentes argumentam que a atividade exercida pelo designer instrucional está relacionada ao tratamento, adequação e organização dos conteúdos (4 respostas). Constatou-se apenas uma resposta abrangente afirmando que o designer instrucional:

[...] atua desde a análise dos conteúdos, criação de um Ambiente Virtual de Aprendizagem coerente com o público-alvo, planejamento de atividades e avaliações de acordo com os objetivos estabelecidos e com o aprendizado do aluno e acompanhar do desenvolvimento dos cursos.

\section{2 \\ Ações concretizadas pelos designers instrucionais relacionadas à construção de Ambientes Virtuais de Aprendizagem, materiais impressos e recursos digitais educativos}

Para compreender as produções dos designers instrucionais, foi perguntado aos pesquisados quais produtos ou resultados físicos e digitais são por eles construídos. De modo geral, o enfoque das respostas aproxima-se da produção de materiais impressos e digitais, abrangendo a construção de vídeos, jogos, materiais em áudio, entre outros produtos que se assemelham a Objetos Interativos de Aprendizagem. Apesar disso, a construção de Ambientes Virtuais de Aprendizagem aparece em algumas das afirmações feitas pelos respondentes.

Foram extraídos das respostas dos pesquisados os elementos gramaticais (verbos e substantivos) expressados pelos designers instrucionais, com o intuito de constatar a gradação da relação entre suas ações e as possíveis práticas características do campo do Design. Identificaram-se 10 verbos e sua relação com os resultados e recursos construídos: "Desenvolver", "Construir", "Elaborar", “Adequar", "Montar", “Orientar", "Entregar", "Planejar”, “Organizar” e “Gerenciar”. A Tabela 2 expõe a frequência identificada: 


\begin{tabular}{|c|c|c|}
\hline \multicolumn{3}{|c|}{$\begin{array}{l}\text { Pergunta número } 11 \text { (aberta): Quais são as ações concretizadas pelos designers } \\
\text { instrucionais relacionadas à produção de material impresso, recursos digitais e/ou } \\
\text { Ambientes Virtuais de Aprendizagem? }\end{array}$} \\
\hline Conteúdos identificados nas respostas: & Quantidade & Percentual \\
\hline Construir OIA. & 15 & $36,7 \%$ \\
\hline Elaborar cursos. & 12 & $29,2 \%$ \\
\hline Desenvolver OIA. & 02 & $5,0 \%$ \\
\hline Adequar AVA. & 03 & $7,3 \%$ \\
\hline Montar AVA. & 02 & $5,0 \%$ \\
\hline Orientar OIA. & 01 & $2,4 \%$ \\
\hline Entregar cursos e OIA. & 01 & $2,4 \%$ \\
\hline Planejar cursos e OIA. & 01 & $2,4 \%$ \\
\hline Construir AVA. & 01 & $2,4 \%$ \\
\hline Desenvolver AVA. & 01 & $2,4 \%$ \\
\hline Organizar AVA. & 01 & $2,4 \%$ \\
\hline Gerenciar AVA. & 01 & $2,4 \%$ \\
\hline
\end{tabular}

Tabela 2 - Análise de conteúdo dos questionários

Fonte: Dados da Pesquisa.

Os verbos "Desenvolver", “Construir", "Elaborar" encontram-se numa relação aproximada ao contexto do Design, que pressupõe uma ação de planejar e desenvolver objetos e ambientes. Os verbos "Adequar" e "Montar" estão num patamar um pouco mais distante em afinidade com o campo do Design. Já os verbos “Orientar", "Entregar”, "Planejar”, “Organizar” e "Gerenciar” encontram-se numa escala mais afastada do âmbito do Design.

Para elucidar esse raciocínio, é relevante resgatar o conceito do Design reportando às considerações de Bomfim \& Portinari (In Couto et al., 2014, p.118) na definição do termo: "design (to design) do latim designare (de + signum) significa desenvolver, conceber”. Nas formulações teóricas dos autores, o campo de ação do Design é o da configuração de objetos. Para Bomfim \& Portinari, “[...] como configuração se entende tanto o processo (configurar), como seu resultado (figura) e ambos pertencem à relação que se estabelece entre sujeito e objeto". (In Couto et al., 2014, p. 44).

Diante disso, é relevante destacar que, dependendo da ação a ser realizada, essa ação poderá estar associada de maneira mais estreita ao campo da Educação do que ao campo do Design. A elaboração de um curso, por exemplo, corresponde a uma tarefa inerente ao campo da Educação. 
Nesta análise, utilizou-se uma escala para mensurar a proximidade das ações dos respondentes com a típica atividade de Design. Assim, utilizou-se parcialmente uma escala de diferencial semântico com o intuito de classificar as respostas dos designers instrucionais. Nessa escala foram adotados dois extremos com dois adjetivos opostos. Um adjetivo polar adotado foi "próximo ao campo do Design" e outro polar oposto "distante ao campo do Design".

A Tabela 3 expõe a gradação da relação entre ações realizadas pelos designers instrucionais e a prática característica do campo do Design:

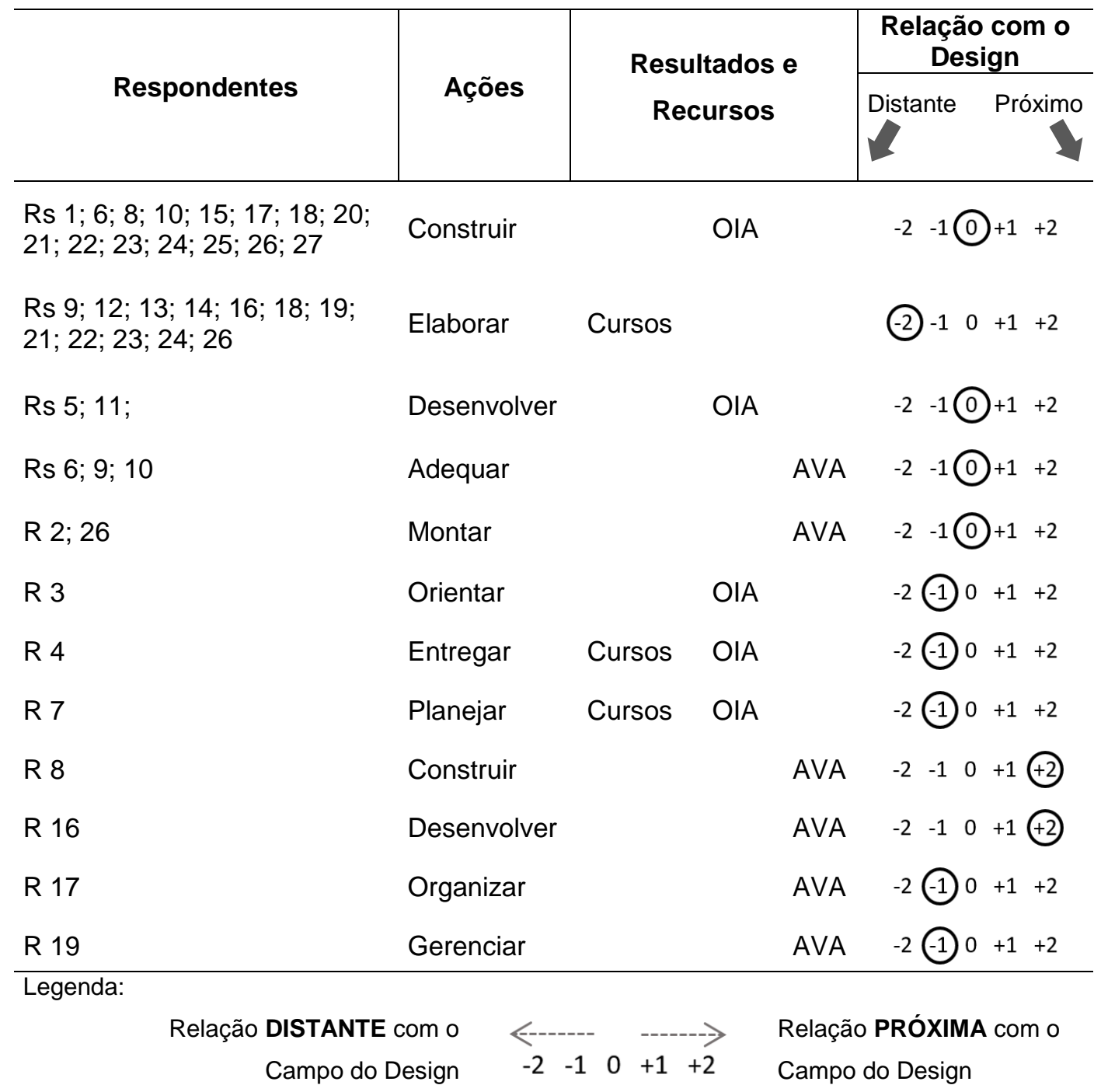

Tabela 3 - Gradação da relação entre ações realizadas pelos designers instrucionais e a prática característica do campo do Design Fonte: Dados da Pesquisa.

Assim, a partir da classificação exposta, foi possível observar que as ações promovidas pelos designers instrucionais pesquisados estão prioritariamente 
dedicadas à produção dos recursos a serem utilizados nos AVAs. A ação de construir OIA mencionada pelos profissionais está relacionada a uma atividade mais próxima ao campo da Educação. Tal ação se distancia de uma proposição metodológica específica do campo do Design.

Quanto às ações diretamente relacionadas aos AVAs, algumas se restringem, de modo geral, a adequar, planejar e organizar o Ambiente, sendo algo restrito e com pouca correspondência com o campo do Design. No entanto, encontram-se afirmações dos pesquisados que se direcionam às ações de construir e desenvolver AVAs, supostamente se aproximando do campo do Design.

\subsection{1 \\ Verificação se os designers instrucionais pesquisados trabalharam na construção de Ambientes Virtuais de Aprendizagem}

Por meio desta pesquisa, foi possível constatar que a atividade realizada pelos 27 designers instrucionais está prioritariamente relacionada a três tipos de ações: a) construção de objetos interativos de aprendizagem; b) elaboração de cursos e c) adequação, montagem, organização e gerenciamento de Ambientes Virtuais de Aprendizagem. Tal constatação é confirmada nas análises a seguir. As ações promovidas pelos designers instrucionais participantes desta investigação estão distanciadas da construção (no sentido estrito da palavra) de novos Ambientes Virtuais de Aprendizagem.

Entre os 27 respondentes, 16 deles (R1; R3; R4; R5; R8; R9; R10; R13; R15; R18; R20; R21; R23; R25; R26 e R27) afirmaram objetivamente que nunca construíram Ambientes Virtuais de Aprendizagem. Há alguns que declararam promover a preparação e adequação de plataformas, no caso particular da plataforma Moodle. São os respondentes R2; R6; R12; R16; R17; R19 e R22. Há também dois respondentes (R14 e R24) que afirmaram construir ambientes, porém foi observado no detalhamento da afirmação que se tratava de uma preparação das plataformas Moodle, Blackboard e Teleduc. No entanto, há respostas pontuais que afirmaram construir AVAs, como é o caso dos respondentes (R7 e R11) em seus respectivos ambientes: "Simulador de Algoritmos e Estruturas de Dados SAED" e o ambiente “Owpoga".

Buscamos conhecer as duas propostas apontadas pelos respondentes (R7 e R11) e constatamos que o Simulador de Algoritmos e Estruturas de Dados (SAED) 
é caracterizado como um software simulador capaz de auxiliar educadores e educandos em processos de ensino-aprendizagem acerca de conteúdos sobre estrutura de dados. Já a proposta do ambiente Owpoga trata-se de sistema complementar para educação que integra jogos ao ambiente da web para estimular o aprendizado de educandos em diferentes temáticas. O Owpoga se apresenta como uma proposta sustentada no conceito de Aprendizagem Baseada em Interesses (ABI), no qual os educandos fazem uso de diferentes recursos que buscam estimular o aprendizado por meio da curiosidade e da construção de conhecimento a partir do uso de jogos e de outros suportes tais como textos e artigos acadêmicos.

O Gráfico 8 expõe o panorama, no qual 11 de 27 respondentes afirmaram preparar, adequar ou construir Ambientes Virtuais de Aprendizagem.

CONSTRUÇÃO DE AMBIENTES VIRTUAIS DE APRENDIZAGEM PELOS DESIGNERS INSTRUCIONAIS

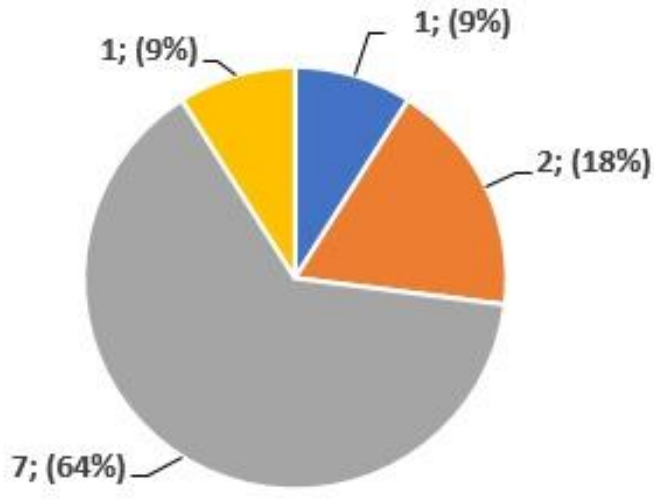

- Construção do Simulador de Algorítmos e Estrutura de Dados - SAED

- Preparação das plataformas: Moodle, Blackboard e Teleduc

= Preparação e adequação de plataformas

= Construção do Ambiente Owpoga

Gráfico 8 - Construção de Ambientes Virtuais de Aprendizagem pelos designers instrucionais Fonte: Dados da Pesquisa.

Notamos, assim, a predominância de situações em que os designers instrucionais realizam a ação de preparação e adequação de Ambientes Virtuais de Aprendizagem. Raramente participam de iniciativas dedicadas à construção de novos ambientes. 


\subsection{2}

\section{Verificação de quais Ambientes Virtuais de Aprendizagem os designers pesquisados ainda não utilizaram ou que gostariam de utilizar}

Considerando que a maioria dos pesquisados ainda não atuou de modo estrito à construção de AVAs, foi perguntado a eles em quais Ambientes Virtuais de Aprendizagem gostariam de trabalhar. A nossa expectativa estava em reconhecer as ações que os participantes realizam e oportunamente descobrir novas propostas de ambientes. Com esta pergunta, obtivemos que 10 dos respondentes disseram que desconhecem outros AVAs em que já não tenham trabalhado. Já trabalharam com todos os que conhecem. As exceções indicam AVAs comumente conhecidos e disponíveis que os pesquisados ainda não utilizaram. A Tabela 4 expõe a relação de AVAs que os designers instrucionais ainda não utilizaram, mas em que gostariam de trabalhar.

\begin{tabular}{l|c}
\hline \multicolumn{1}{c|}{$\begin{array}{c}\text { Nome de AVAs que ainda não utilizaram, mas em que } \\
\text { gostariam de trabalhar. }\end{array}$} & $\begin{array}{c}\text { Número de } \\
\text { Ocorrências }\end{array}$ \\
\hline Canvas & 1 \\
Coursera & 1 \\
Google Classroom & 1 \\
MOOCs (Coursera, EDX e Udacity) & 1 \\
Office365 para a Educação & 1 \\
Teleduc & 1 \\
Teleduc e Dokeos & 1 \\
Blackboard & 3 \\
Outros (não especificaram) & 7 \\
Não há & 10 \\
\hline
\end{tabular}

Tabela 1 - Relação de AVAs que os designers instrucionais gostariam de utilizar Fonte: Dados da Pesquisa.

Observa-se a partir das informações levantadas pela pesquisa que os Ambientes Virtuais de Aprendizagem que os designers instrucionais gostariam de utilizar são Blackboard, Google Classroom, MOOCS (EdX, Coursera), Office365 para a Educação, Teleduc, entre outros. Não houve incidência de entrevistados que ainda não tivessem utilizado o ambiente Moodle. Nota-se também uma parcela 
significativa de designers instrucionais - 10 do total de 27 - que expressaram negativamente o interesse por utilizar AVAs dos quais não tenham conhecimento.

\subsection{3 \\ Verificação de qual é o melhor Ambiente Virtual de Aprendizagem na opinião dos pesquisados}

A pesquisa também buscou identificar o Ambiente Virtual de Aprendizagem mais adequado na opinião dos pesquisados. Os designers instrucionais sinalizaram majoritariamente o Moodle como aquele que apresenta as melhores características e funcionalidades. A Tabela 5 expressa a preferência dos pesquisados.

\begin{tabular}{lc}
\hline Moodle & 17 respostas \\
Preferiram não destacar & 8 respostas \\
Backboard & 1 resposta \\
Youtube & 1 resposta
\end{tabular}

Tabela 5 - O melhor Ambiente Virtual de Aprendizagem na opinião dos pesquisados Fonte: Dados da Pesquisa.

A partir dessas informações, notamos que o Moodle se destaca como um ambiente que permanece na preferência de muitos usuários. Essa observação reforça os dados discutidos no capítulo 3 , em que apontamos que, conforme informações do diretório Capterra na edição de 2016, o Moodle possui mais de 89 milhões de usuários.

\subsection{4}

\section{Verificação acerca da apropriação de recursos em Três Dimensões "3D" na produção de Ambientes Virtuais de Aprendizagem}

Buscamos também investigar se os designers instrucionais conhecem Ambientes Virtuais de Aprendizagem produzidos com características em Três Dimensões "3D". O intento era identificar e localizar ambientes com propostas educativas a partir da imersão de usuários em ambiente tridimensional. A maioria (19 dos pesquisados) afirmou desconhecer algum ambiente com essas características. Já 5 consideraram o ambiente Second Life como um AVAs utilizado em situações de ensino-aprendizagem. Neste caso, o ambiente referido pelos pesquisados sugere ser o Second Life, mas também o Sloodle, que é um projeto de 
código livre e aberto que integra os ambientes virtuais multiusuário do Second Life e/ou OpenSim com a plataforma Moodle.

Conforme Nakamura (2009, p.150),

O Sloodle é definido como um "mashup" entre o ambiente tridimensional "Second Life" e o "Moodle". Em outras palavras, é um programa OpenSource. A ideia é reunir recursos de Web LMS (do qual o Moodle é um dos principais expoentes) com jogos interativos baseados em ambiente virtual 3D Multi-usuário (que tem como principal representante, hoje, o Second Life). (Nakamura, 2008, p.150)

No Sloodle (Figura 2), os usuários participam das aulas em um ambiente virtual, no qual encontram e interagem com colegas e educadores, por meio do uso de avatares. Em informática, um avatar se caracteriza como um "cibercorpo", inteiramente digital, sendo um personagem que empresta sua vida simulada em mundos paralelos do ciberespaço. E o ciberespaço é definido como "o espaço de comunicação aberto pela interconexão mundial dos computadores e das memórias dos computadores" (Lévy, 1999, p. 92).

\footnotetext{
${ }^{6}$ Um mashup é um website ou uma aplicação web que usa conteúdo de mais de uma fonte para criar um novo serviço completo. No caso do Sloodle, é uma terceira aplicação que reúne em si o desenvolvimento de duas outras plataformas, formando um novo serviço. (Nakamura, 2009, p.150)
} 

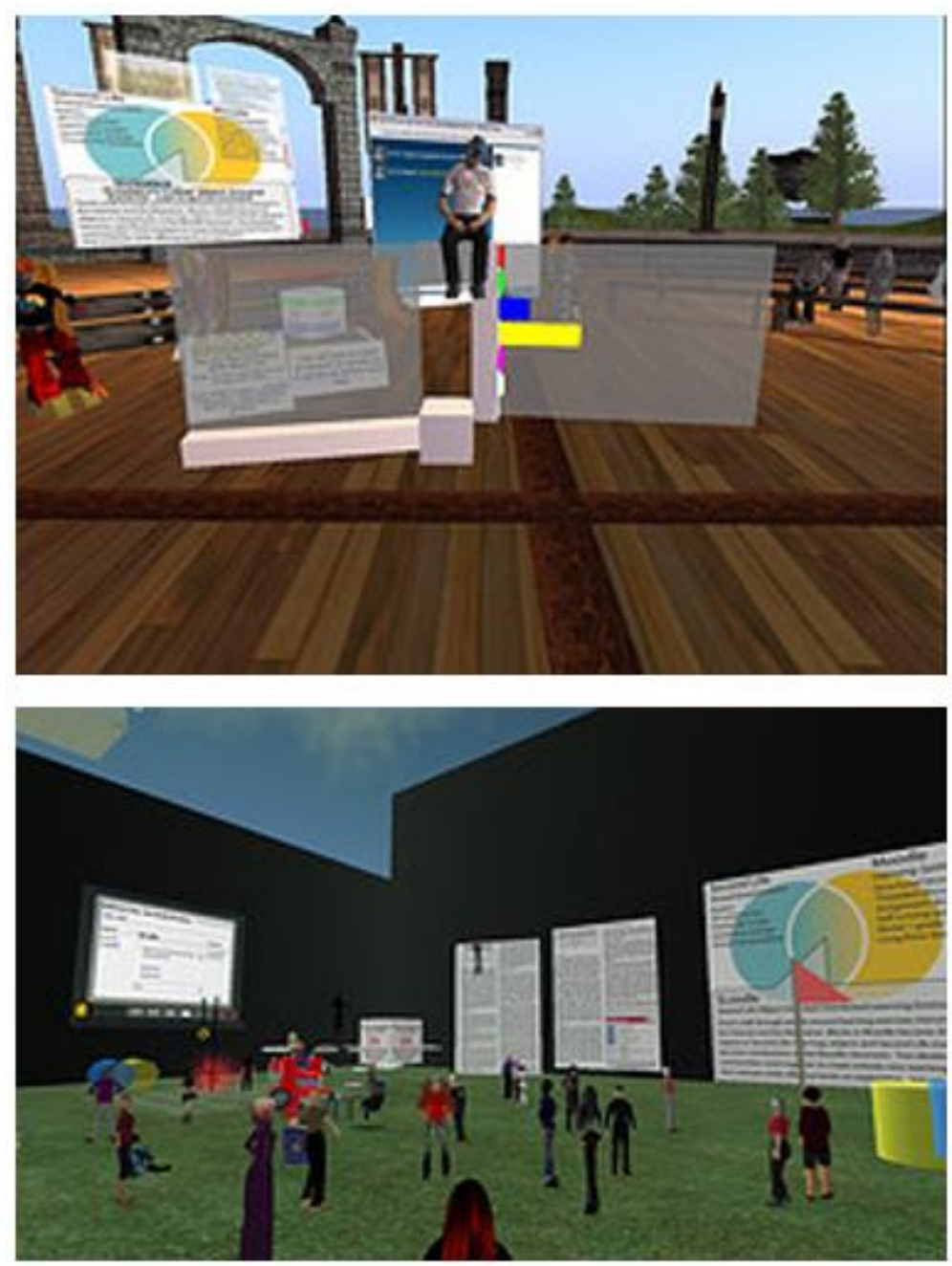

Figura 2 - Exemplo de utilização do Sloodle Fonte: Sloodle (2015).

No Sloodle, os educadores preparam um ambiente para realizar as aulas com inúmeras possibilidades de interação, no qual os educandos podem fazer uso de recursos tais como discussões e bate-papos utilizando arquivos de áudio ou texto. As discussões podem ser arquivadas no banco de dados do Moodle. Os slides e os documentos das aulas podem ser disponibilizados e visualizados em placas virtuais, e também ser direcionados ao Moodle. No ambiente Sloodle há a possibilidade de os usuários criarem objetos, textos e softwares de modo colaborativo e disponibilizá-los para experimentação com os demais educandos. $\mathrm{O}$ ambiente propicia a interação com o uso de vídeos, chats, além de permitir a criação de sistemas internos dedicados especificamente à realização de simulações.

O fato de o Sloodle ser baseado no Second Life já traz indícios de uma tentativa de proporcionar a ampliação do conceito de interação no âmbito educacional. Conforme Mattar (2008, p.1): 
[...] os ambientes de realidade virtual 3D, como o Second Life, ampliam o significado do conceito de interação, pelas novas e ricas relações que se estabelecem entre os alunos, os professores, o conteúdo e o próprio ambiente de ensino.

O Sloodle oferece uma variedade de funcionalidades para apoio à aprendizagem em um contexto virtual de imersão. Seus recursos se apresentam de forma integrada a uma plataforma virtual, no caso o Moodle.

A Tabela 6 expõe a síntese das respostas dos pesquisados em relação aos Ambientes Virtuais de Aprendizagem que conhecem, produzidos com características em Três Dimensões "3D":

\begin{tabular}{lc}
\hline Não conhecem & 19 - respostas \\
Second Life & 04 - respostas \\
Owpoga & 01 - resposta \\
Second Life e Jogo The Sims 4 & 01 - resposta \\
(Professor Ricardo Nunes) que utilizava um jogo 3D para & 01 - resposta \\
dar suas palestras/cursos & 01 - resposta \\
\hline
\end{tabular}

Tabela 6 - Ambiente Virtual de Aprendizagem produzido em Três Dimensões "3D" Fonte: Dados da pesquisa.

O ambiente Owpoga, mencionado pelo Respondente 11, é um sistema web de gerenciamento de jogos. Nesse espaço há diversos jogos hospedados e categorizados como enfoque social e educacional. O jogo The Sims 4 , mencionado pelo "Respondente 14", trata-se de um jogo eletrônico de simulação de vida, produzido pela empresa "Electronic Arts", sendo compatível e executável em computadores.

Já a afirmação do "Respondente 17" indica a utilização de jogo construído para exposição e hospedagem de palestras e cursos criados por um educador. Entretanto, não foi possível identificar ou acessar a construção referenciada. Nos dizeres do respondente:

O mais parecido que me contaram é um professor amigo meu que utilizava um jogo 3D para dar suas palestras/cursos nele. As pessoas interessadas entravam no curso e se encontravam em um determinado espaço do jogo para conversarem e debaterem sobre a palestra/curso. Nunca participei. (R17). 
E finalmente o ambiente La grotte de Lascaux, mencionado pelo Respondente 15, refere-se a um portal que oferece a visita virtual dos usuários a um complexo de cavernas situado no sudoeste da França, que dispõe de várias pinturas rupestres.

\subsection{5 \\ Ambientes Virtuais de Aprendizagem utilizados pelos designers instrucionais pesquisados}

As informações geradas através desta pesquisa demonstram que a maioria dos designers instrucionais (20 do total de 27) utiliza ou utilizou o ambiente Moodle em suas atuações. Essa constatação aponta que o ambiente virtual Moodle é destacado como aquele que apresenta melhores características e funcionalidades, na opinião dos pesquisados. Também foi possível constatar que o Moodle é o AVA prioritariamente utilizado pelo grupo de designers instrucionais pesquisados, conforme demonstra a Tabela 7:

\begin{tabular}{ccc}
\hline Moodle & 20 & $74 \%$ \\
Blackboard & 3 & $11 \%$ \\
EdX & 0 & $0 \%$ \\
Coursera & 0 & $0 \%$ \\
Udacity & 0 & $0 \%$ \\
Teleduc & 0 & $0 \%$ \\
Outros & 4 & $15 \%$
\end{tabular}

Tabela 7 - Ambiente Virtual de Aprendizagem que os designers utilizam/utilizaram em sua atuação

Fonte: Dados da pesquisa.

As informações coletadas revelam certa unicidade pelo Ambiente Virtual de Aprendizagem Moodle com $74 \%$ das indicações dos pesquisados, como indica a Tabela 6.

\subsection{6}

\section{Adequação dos Ambientes Virtuais de Aprendizagem que os designers instrucionais utilizam ou já utilizaram}

Buscamos também realizar junto aos pesquisados uma avaliação da adequação daqueles Ambientes Virtuais de Aprendizagem que eles utilizam ou já utilizaram. Mantivemos a pergunta de modo abrangente, para não avaliar um 
ambiente específico, e sim aqueles que os pesquisados já conhecem. Observamos que os pesquisados consideram predominantemente a condição de "parcialmente adequado", conforme a porcentagem na Tabela 8:

\begin{tabular}{lcc}
\hline Totalmente inadequado & 0 & $0 \%$ \\
Parcialmente inadequado & 4 & $15 \%$ \\
Não sei & 1 & $3 \%$ \\
Parcialmente adequado & 17 & $63 \%$ \\
Totalmente adequado & 5 & $19 \%$
\end{tabular}

Tabela 8 - Avaliação quanto à adequação do Ambiente Virtual de Aprendizagem que os designers instrucionais utilizam/utilizaram Fonte: Dados da pesquisa.

Constatamos com essa pergunta que os pesquisados avaliam como parcialmente adequados os ambientes que utilizam/utilizaram em propostas de Educação a Distância. No entanto, as respostas indicam que há fortemente a necessidade de aprimoramento nos ambientes e que os designers instrucionais podem contribuir indicando quais são as possíveis melhorias.

\subsection{7 \\ Possibilidade de mudança de Ambientes Virtuais de Aprendizagem utilizados}

No que se refere à possibilidade de mudança de AVAs utilizados pelos designers instrucionais, 13 respondentes (R3; R7; R9; R12; R17; R18; R20; R21; R22; R23; R24; R26 e R27) do total de 27 sinalizaram que não mudariam de AVA. Já 5 (R1; R2; R11; R19; R25) expressaram que somente mudariam caso lhes fosse apresentado outro AVA com melhores características daquelas que o Moodle já oferece. Outros 9 (R4; R5; R6; R8; R10; R13; R14; R15; R16) disseram que gostariam de mudar de AVAs. E, neste caso, as afirmações sinalizam variadas justificativas pela mudança. Algumas dessas são assim pontuadas:

a) possibilidades ampliadas na configuração final;

b) flexibilidades na interface;

c) melhorias nas funcionalidades de comunicação;

d) possibilidades de organização e interação; e 
e) integração com recursos similares às redes sociais digitais.

Diante disso, se confrontarmos as respostas desta subseção com aquelas da subseção 4.2.5, conseguiremos revelar algumas informações relevantes. Naquela subseção, 20 (vinte) respondentes do total de 27 (vinte e sete), afirmaram que o Moodle é o ambiente virtual de aprendizagem prioritariamente utilizado por eles. Já nesta subseção, 09 (nove) respondentes sinalizam a necessidade de melhorias estruturais no Moodle. Neste caso, a partir desta confrontação de dados, podemos reconhecer que embora o Moodle apresente características em potencial, ainda é necessário realizar inúmeros aprimoramentos.

Percebemos com essas afirmações a existência de uma demanda por melhorias relacionadas a flexibilidade, interface e interação. Essencialmente, notamos que ações interdisciplinares com a participação do Design poderão contribuir para o aperfeiçoamento dos ambientes existentes.

\subsection{8 \\ Nível de alterações realizadas pelos designers instrucionais nos Ambientes Virtuais de Aprendizagem}

A pesquisa também buscou levantar os níveis de alterações e ajustes promovidos pelos designers instrucionais nos Ambientes Virtuais de Aprendizagem. O objetivo foi identificar o grau de alterações e modificações realizadas em suas ações. Nota-se certo equilíbrio nas respostas quanto aos níveis de alterações, conforme a Tabela 9.

\begin{tabular}{lcc}
\hline Não faço alterações, pois o AVA é padronizado. & 7 & $26 \%$ \\
Não faço alterações, pois não vejo necessidade. & 0 & $0 \%$ \\
Faço apenas alterações parciais. & 8 & $29 \%$ \\
Faço alterações regulares. & 4 & $15 \%$ \\
Faço muitas alterações no AVA. & 8 & $30 \%$ \\
Não sei responder. & 0 & $0 \%$ \\
\hline
\end{tabular}

Tabela 9 - Nível de alterações realizadas pelos designers instrucionais nos Ambientes Virtuais de Aprendizagem

Fonte: Dados da pesquisa. 
A partir dessas respostas, foi possível reconhecer que majoritariamente os designers instrucionais pesquisados afirmam realizar alterações nos ambientes. Um total de $64 \%$ dos pesquisados fazem algum tipo de alteração, contra $26 \%$ que afirmam não realizar modificações em AVAs. Também percebemos que 30\% dos pesquisados disseram fazer muitas alterações nos AVAs.

Tais afirmações sinalizam que os ambientes virtuais de aprendizagem são recursos que necessariamente carecem de ajustes, adaptações e adequações às propostas de cursos a distância. Além disso, podemos reconhecer que quanto mais suscetibilidade à realização dos ajustes os AVAs apresentarem, melhor será seu nível de adaptabilidade, facilitando à adequação aos variados modelos de ensino.

\section{3 \\ As metodologias utilizadas nas produções de recursos (como produzem e quais ferramentas, técnicas ou teorias são utilizadas)}

Após identificarmos quais os ambientes que os designers instrucionais utilizam e analisar as impressões que possuem sobre tais ambientes, buscamos reconhecer quais as metodologias que utilizam na construção de recursos para a educação. As informações geradas a partir desse questionamento demonstram a incidência de pouca variedade de métodos utilizados pelos designers instrucionais investigados. Quando perguntados sobre quais metodologias adotam nos trabalhos que desenvolvem, identificamos nas respostas a ausência da utilização de métodos e técnicas específicas do campo do Design. As metodologias que se repetem são o modelo ADDIE com cinco ocorrências e a proposta de construção de Storyboard, com três ocorrências. As metodologias utilizadas pelos designers instrucionais encontram-se relacionadas conforme segue:

- Modelo ADDIE - (Análise, Desenho, Desenvolvimento, Implementação e Avaliação).

- Construção do Storyboard + Construção do Mapa de Atividades + Mapa Conceitual.

- Metodologia 6D (Seis Disciplinas: Determinar os resultados para o negócio / Desenhar uma experiência completa/ Direcionar a aplicação / Definir a transferência do aprendizado / Dar apoio à performance / Documentar os resultados). 
- Experiência do usuário: (ergonomia, interface, linguagem e sistema).

- Pedagogia de Projetos, Webquest, Taxonomia de Bloom, Gameficação, Rede de Aprendizagem, Aprendizagem Efetiva.

- Construtivismo + Aprendizagem Baseada em Interesses (ABI).

- Estímulo à criatividade (Ken Robinson).

- Associação das teorias da aprendizagem (tradicional, construtivista, sociointeracionista).

- Proposta de Mayer + Ergonomia + IHC (Interação Humano Computador).

A partir desse levantamento, foi possível notar em algumas afirmações dos pesquisados a evidência do uso de métodos que se aproximam ao campo do Design, particularmente nas afirmações que mencionam a utilização de critérios da Ergonomia e da Interação Humano-Computador, pois são algumas das proposições correlatas ao campo do Design. São critérios que embasam as ações de Design.

A pesquisa também se dedicou a levantar informações relacionadas aos recursos e às características que um AVA necessita disponibilizar aos agentes da Educação a Distância, especificamente aos tutores e educandos. Inicialmente, no âmbito dos tutores, foram reveladas informações que apontam para recursos que expandem a interação e as funcionalidades, permitindo um acompanhamento detalhado e ampliado pelos tutores do aprendizado dos educandos, por meio dos AVAs.

A relação que segue apresenta as proposições dos pesquisados no que se refere aos recursos e funcionalidades que um Ambiente Virtual de Aprendizagem necessita disponibilizar, especificamente aos tutores:

- diversificação de recursos (fóruns, chats, jogos, glossários, quizzes e vídeos);

- interface amigável e inserção de ferramentas para contato, interação, socialização e interlocução com os educandos;

- recursos com relatórios e informações do desenvolvimento dos educandos.

Neste sentido, os resultados alcançados por meio desta pesquisa demonstram que os argumentos dos designers instrucionais se direcionam a uma proposição da 
ampliação da interação e do aprimoramento da aprendizagem a partir da interlocução próxima aos educandos.

Considerando que os pesquisados já haviam sinalizado que o ambiente Moodle dispõe de funcionalidades e recursos capazes de contemplar essas demandas, é possível reconhecer o potencial disponível pelo Moodle, bem como as possibilidades passíveis de serem aprimoradas tendo como norteadores aspectos relacionados à interação e ao acompanhamento do estudante.

Posteriormente, quando perguntamos aos designers instrucionais acerca dos aspectos e elementos que um AVA necessita disponibilizar aos educandos, expressaram a necessidade de recursos que favoreçam a compreensão dos conteúdos e se direcionem para a perspectiva da interação e da aproximação entre educandos e educadores, igualmente mencionada nas respostas do item anterior. Sabe-se, entretanto, que a compreensão mais real do que um AVA precisa dispor aos educandos perpassa essencialmente pela necessidade de questioná-los também. É necessário ter acesso à concepção dos educandos, investigando de que necessitam e, de modo especial, questioná-los durante as situações de uso dos ambientes.

A relação seguinte expõe as respostas dos designers instrucionais acerca dos recursos e funcionalidades que um Ambiente Virtual de Aprendizagem necessita disponibilizar especificamente aos educandos:

- Diversidade de recursos e de Objetos de Aprendizagem.

- Acesso a dados pessoais de desempenho individual.

- Acesso facilitado, compreensão completa do funcionamento, experiência didática facilitadora, suporte técnico ágil e eficaz.

- Recursos de interação síncrona e assíncrona, materiais de qualidade, atividades individuais e colaborativas, além de disponibilização de relatórios.

- Material bem estruturado e de boa qualidade, intercalando texto, imagens, vídeos, e sem animações que o façam perder tempo quando se trata de $\mathrm{EaD}$ para adultos.

- Adaptabilidade aos dispositivos móveis.

- Segurança e proteção das informações. 
A partir dessas informações, é possível notar a demanda pela disponibilização de recursos e funcionalidades capazes de promover a interação, a aproximação entre tutores e educandos, de modo a facilitar o processo de ensino-aprendizagem. Esse quesito destaca-se com uma estratégia fundamental na construção e preparação de AVAs.

A pesquisa também buscou informações ligadas à avaliação por tutores e educandos do AVA utilizado. Foi perguntado inicialmente aos designers instrucionais se os tutores avaliam positivamente os AVAs produzidos e utilizados nos cursos na modalidade a distância em que trabalham. Neste caso, uma parcela considerável de designers instrucionais desconhece a opinião dos tutores quanto à adequação do AVA que utilizam. A Tabela 10 expõe a porcentagem da adequação do AVA na avaliação dos tutores.

\begin{tabular}{lcc}
\hline Totalmente inadequado & 0 & $0 \%$ \\
Parcialmente inadequado & 2 & $7 \%$ \\
Não sei & 12 & $45 \%$ \\
Parcialmente adequado & 12 & $44 \%$ \\
Totalmente adequado & 1 & $4 \%$
\end{tabular}

Tabela 10 - Avaliação da adequação do Ambiente Virtual de Aprendizagem pelos tutores Fonte: Dados da pesquisa.

Notamos que uma parcela significativa dos designers instrucionais não possui uma avaliação (feedback) dos tutores em relação ao ambiente. Consideramos que obter uma avaliação dos usuários é fundamental para aprimorar tanto os projetos consolidados quanto aqueles em fase de implementação.

Posteriormente às questões sobre a adequação de AVAs na concepção dos tutores, passamos a perguntar acerca da avaliação da adequação do AVA pelos educandos. Nesse item também ficou explícito uma parcela significativa de designers instrucionais desconhecer a avaliação dos educandos quanto à adequação do AVA (Tabela 11).

\begin{tabular}{lcc}
\hline Totalmente inadequado & 0 & $0 \%$ \\
Parcialmente inadequado & 4 & $15 \%$ \\
Não sei & 11 & $41 \%$ \\
Parcialmente adequado & 11 & $41 \%$ \\
\hline
\end{tabular}


\begin{tabular}{l}
\hline Totalmente adequado \\
$\begin{array}{l}\text { Tabela } 11-\text { Avaliação da adequação do Ambiente Virtual de Aprendizagem pelos } \\
\text { educandos }\end{array}$ \\
Fonte: Dados da pesquisa.
\end{tabular}

A Tabela 11 explicita igualmente a questão anterior, ou seja, a ausência de avaliações (feedback) dos tutores em relação ao ambiente.

\section{4 \\ As possibilidades e perspectivas de ações e produções pelo profissional designer instrucional (melhorias da atuação, avaliação das ações e novos rumos)}

A presente pesquisa possibilitou também verificar quais as principais ações de um designer instrucional para favorecer processos de ensino-aprendizagem interativos. De modo geral, essas ações estão relacionadas ao planejamento pedagógico e à produção de materiais numa perspectiva dialógica, que estimule a participação e o aprendizado dos envolvidos. A relação de expressões e informações ligadas às melhorias de atuação e novas ações são dispostas como segue:

- pautar a construção de materiais no dialogismo mostrando ao aluno que a construção do conhecimento é um processo no qual ele é atuante, não espectador;

- diversificar a utilização de mídias, produzir recursos capazes de promover situações de interação, de incentivo à criatividade e superação de desafios;

- estudo de público-alvo, planejamento didático, adaptação do conteúdo, adaptação da linguagem, Atividades gamificadas, promoção de objetos e comandos que viabilizem experiências de aprendizagem;

- considerar as teorias da aprendizagem, o uso de tecnologias assistivas e adoção de critérios de usabilidade e acessibilidade;

- desenhar situações de aprendizagem, evitando-se a mera transposição de conteúdos, e organizar de forma clara a informação.

Por meio da análise das informações coletadas sobre as ações do designer instrucional, foi possível notar o interesse em promover estratégias para aprimorar 
os processos de aprendizagem. Entre as possibilidades elencadas a partir dessa indagação, encontram-se o interesse por ações focadas no dialogismo, na diversificação das mídias e das atividades, promoção de ações que potencializem a participação das equipes envolvidas, adaptação da linguagem, uso de tecnologias assistivas e aprimoramento constante da usabilidade e da acessibilidade.

\subsection{1 Possibilidades de esquemas de comunicação em Ambientes Virtuais de Aprendizagem}

Também foi perguntado aos designers instrucionais sobre a percepção que têm quanto às características dos recursos disponíveis nos AVAs que utilizam, se esses apresentam esquemas lineares ou não lineares de comunicação. $\mathrm{O}$ intento dessa pergunta foi compreender as características de comunicação disponíveis em AVAs produzidos pelos pesquisados. As respostas dos designers se apresentaram divididas equilibradamente entre esquemas lineares ou não lineares e indicam possibilidades de melhorias de comunicação, conforme o Gráfico 9.

\section{ESQUEMAS DE COMUNICAÇÃO EM RECURSOS DISPONIVEIS AOS EDUCANDOS E TUTORES}

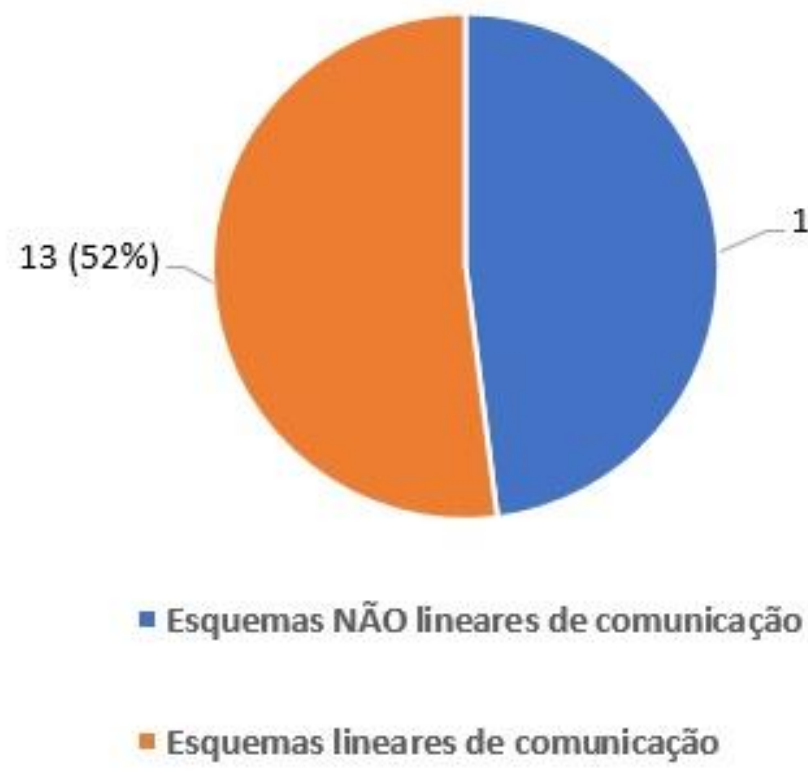

Gráfico 9 - Esquemas de comunicação em recursos disponíveis aos educandos e tutores Fonte: Dados da pesquisa. 
A pesquisa também buscou levantar os posicionamentos quanto aos níveis de interação ofertados pelos recursos digitais e/ou Ambientes Virtuais de Aprendizagem, possivelmente construídos/preparados pelos designers instrucionais. O Gráfico 10 expõe a síntese das afirmações dos pesquisados.

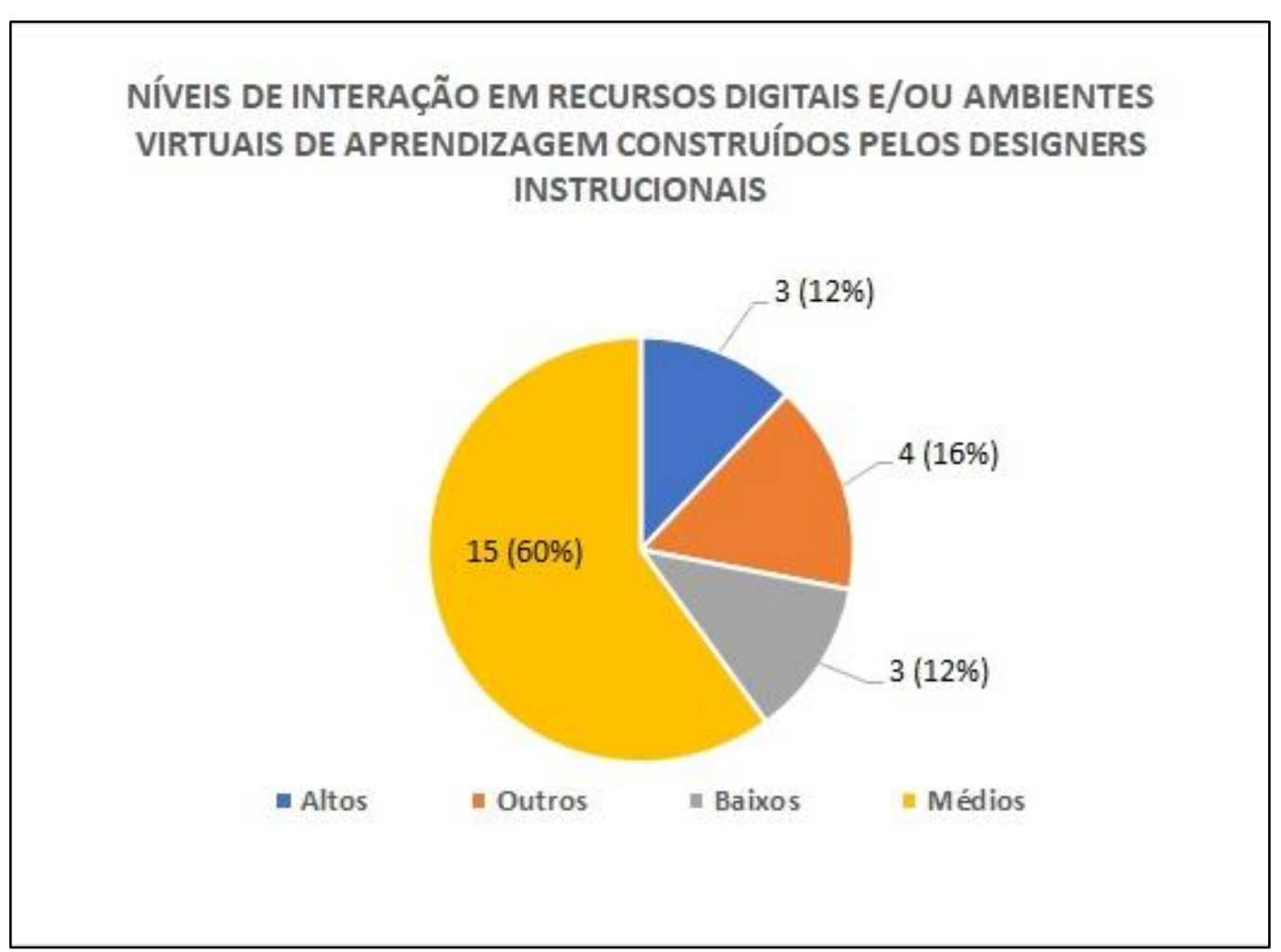

Gráfico 10 - Níveis de interação em recursos digitais e/ou Ambientes Virtuais de Aprendizagem construídos pelos designers instrucionais Fonte: Dados da pesquisa.

No levantamento das informações relacionadas à interação, alguns dos pesquisados associaram o conceito ao uso de recursos digitais, e outros o associaram às práticas educativas. Dessas considerações são expostos alguns extratos das respostas que detalham os argumentos, esclarecimentos acerca dos níveis de interação disponíveis pelos recursos digitais e/ou Ambientes Virtuais de Aprendizagem possivelmente construídos pelos pesquisados.

Respondente 2: No curso atual, os alunos interagem na plataforma e através das redes sociais (Facebook e YouTube). E também há transmissões on-line.

Respondente 3: Procuro utilizar fóruns de debate e, quando possível, utilizo chats para promover a interação entre alunos/alunos e alunos/tutores, além de videoaulas para promover a interação entre alunos e professores e aluno e material didático 
utilizado. Instigo os professores a utilizarem as redes sociais, quando possível, e a utilizarem materiais que promovam a interação do aluno com os conteúdos (jogos, softwares, sites). Entretanto, tenho encontrado dificuldades nesse aspecto.

Respondente 8: Há muitas possibilidades. Mas é preciso saber elaborar as atividades. Porque a plataforma é só um "esqueleto", uma estrutura tecnológica. A interação efetivamente é proporcionada pela forma como as atividades são elaboradas e mediadas.

Respondente 9: Normalmente utilizo fórum de discussão. Então considero que a interação não ocorre em nível alto, por ser uma ferramenta assíncrona.

Respondente 10: Privilegiamos o uso de fórum de discussão, ferramenta que promove boa interação.

Respondente 11: Evito o uso de mídias sociais, acho que aceitar essa mistura pode ser uma ação perigosa (uma faca de dois gumes).

Respondente 12: Normalmente os cursos produzidos em minha instituição são de autoaprendizagem.

Respondente 20: Acredito que o nível de interação dos recursos utilizados depende muito da atuação que os tutores têm sobre o ambiente. Não resolve ter um material muito interativo, um ambiente com grandes possibilidades e tutores que não favorecem a interação, que não promovam a interação.

Respondente 25: Antes de tudo, é preciso definir "Interação". A questão é muito complexa para ser respondida aqui. Enviar mensagens e receber resposta assíncrona não pode ser considerado hoje em dia como "alto" grau de interatividade. E não é o designer instrucional quem toma as decisões de projeto que poderiam mudar isso.

É possível reconhecer nas afirmações que o nível de interação pode ser intensificado a partir das atividades propostas no planejamento dos cursos. A utilização de recursos externos ao Ambiente Virtual de Aprendizagem pode facilitar e potencializar os níveis de interação. Neste particular, considera-se que os AVAs não determinam os níveis de interação. Entretanto, o desenvolvimento planejado de AVAs é capaz de facilitar ou propiciar a promoção da interatividade entre tutores, educandos e conteúdo. Foi possível reconhecer que o AVA, em si, não determina os níveis de interação, mas é um elemento que pode facilitar ou estimular os usuários a interagir.

Também foi possível constatar em tais afirmações, indicativos de que os Ambientes Virtuais de Aprendizagem não dispõem de recursos que atendam a plenitude das demandas dos educadores e educandos. Necessitando assim, da procura por recursos de interação fora dos ambientes. 
4.4.2

Possibilidades na criação de Ambientes Virtuais de Aprendizagem

Buscou-se também, por meio desta pesquisa, coletar informações acerca da experiência dos designers instrucionais na construção ou preparação de Ambiente Virtual de Aprendizagem. Pediu-se a breve exposição da experiência, caso a resposta fosse afirmativa. As expressões que seguem revelam a síntese das informações reveladas e a experiência dos designers instrucionais que afirmaram construir Ambientes Virtuais de Aprendizagem. Particularmente, temos as afirmações dos Respondentes 7 e 10, conforme segue:

Respondente 7: Sim. A experiência nos deixa claro que deve ser incessante a busca pela qualidade dos ambientes virtuais, da mesma forma como são infinitas as possibilidades. São muitas as variáveis e, quando não se tem uma clareza das variáveis envolvidas no contexto específico de cada projeto, pouco se pode fazer! Todo ambiente é um produto de um modelo, e devem ser os modelos os merecedores de toda a atenção e esforços existentes!

Respondente 11: Com mencionei anteriormente, estou desenvolvendo meu próprio sistema: www.owpoga.com. Já alterei muitos recursos do Moodle para algumas necessidades que tive, tenho também um projeto de sistema que faz integração com o Moodle, mas que pode se adaptar para qualquer AVA, onde faço vendas de cursos de forma totalmente automatizada através do PagSeguro, que pode ser visto em um de meus sites www.eadgames.com.br. O grande problema que enfrento é a falta de apoio financeiro, todos querem tudo de graça, mas quem paga as contas de que os faz?

A partir da indagação acerca da construção ou preparação de AVAs, a maioria dos designers instrucionais (17 do total de 27 pesquisados) afirmaram que não participaram da construção de ambientes. Cinco dos pesquisados consideram a configuração da plataforma Moodle de código fonte aberta uma construção de Ambiente Virtual de Aprendizagem. Quatro dos pesquisados expõem suas experiências de construção, contudo não explicitam que se trata de uma configuração ou construção. E apenas no caso do respondente 11, há a exposição de informações que revelam a construção de AVA em integração com os recursos do Moodle. 


\subsection{3 \\ Critérios, métodos e técnicas a serem adotados na construção de Ambientes Virtuais de Aprendizagem}

A pesquisa buscou identificar quais critérios, métodos e técnicas os designers instrucionais adotam ou adotariam numa possível construção de AVAs. Nesse particular, o intento foi evidenciar métodos e técnicas que ainda não tivessem utilizado, mas que se interessariam em conhecer ou utilizar em outras situações. As expressões que seguem expõem as afirmações dos pesquisados em relação aos critérios, métodos e técnicas a serem adotados na construção de Ambientes Virtuais de Aprendizagem.

Respondente 6: Temos trabalhado com o método Lean de produção (ou algo parecido com ele).

Respondente 15: http://www.aprenderlivre.com.br/moodle/login/index.php

Respondente 16: Acho que utilizaria métodos para o desenvolvimento de jogos.

Respondente 22: Contextualizado.

Respondente 23: De maneira geral eu gosto do método desta empresa. Porém, eu gostaria que existisse uma equipe para testar os cursos antes de serem enviados aos alunos, para que a produção do curso em questão fosse melhorada de imediato e não apenas em outros cursos.

Respondente 24: Basicamente, ciclo do PDCA e matriz de SWOT, ferramentas de melhoria contínua e identificação de pontos fortes e fracos. Tangibilizar a opinião dos alunos via pesquisa de qualidade percebida. Relatórios dos tutores também.

Respondente 25: Pesquisas constantes com usuários, avaliação heurística, análise da tarefa ao longo do processo de projetação e implementação.

Respondente 26: $1^{\circ}$ ) pesquisa de preferência com potenciais usuários: estudantes, tutores, DIs, equipes de apoio etc.; $2^{\circ}$ ) envolver representantes de cada tipo de usuário ao longo do projeto; $3^{\circ}$ ) priorizar a simplicidade, a usabilidade e a acessibilidade. Menos é mais! $4^{\circ}$ ) constantemente avaliar a percepção dos usuários.

É possível perceber que, de modo geral, os designers instrucionais sinalizam que critérios, métodos e técnicas a serem adotados estão alinhados à perspectiva da interação, flexibilidade, robustez, interface intuitiva, entre outros. As respostas apresentam sugestões conceituais e praticamente não indicam um método ou técnica específica. A exceção está nos argumentos dos respondentes R6 e R24, que sugerem os métodos Lean Manufacturing, Ciclo PDCA e a Matriz de SWOT. 
O Método Lean Manufacturing, traduzido como "Manufatura Enxuta", também chamado de Sistema Toyota de Produção, trata-se de uma proposta de gestão da produção focada na redução de sete tipos de desperdícios: superprodução, tempo de espera, transporte, excesso de processamento, inventário, movimento e defeitos. O Ciclo PDCA refere-se ao processo de produção estabelecido em quatro etapas: Planejar; Desempenhar; Conferir e Ajustar.

Finalmente, a Matriz de SWOT é um acrônico das palavras strengths, weaknesses, opportunities and threats, que significam, respectivamente: forças, fraquezas, oportunidades e ameaças. Trata-se de uma ferramenta da administração que possui como finalidade principal avaliar os ambientes internos e externos, apresentando possibilidades de negócios. Notadamente, essa ferramenta do campo da administração, não a reconhecemos no foco desta pesquisa como um método ou técnica específica para a construção de AVAs.

\section{5 Considerações acerca das contribuições do design instrucional na construção de Ambientes Virtuais de Aprendizagem}

O levantamento de informações realizado junto ao grupo dos 27 designers instrucionais pesquisados revela que a construção de AVAs ainda está incipiente no âmbito da área de Design Instrucional. De modo geral, encontram-se iniciativas relacionadas à "configuração" da plataforma Moodle tradicionalmente conhecida. $\mathrm{Na}$ concepção dos pesquisados, a disposição de recursos e funcionalidades nos AVAs colabora para a promoção de situações interativas e favorece processos de ensino-aprendizagem.

Contudo, a interação pode ser promovida através de associação e integração de outros recursos digitais externos aos Ambientes Virtuais de Aprendizagem. Assim, a construção de AVAs é algo que favorece situações interativas de ensinoaprendizagem, mas não é o fator determinante dessa interação. A pesquisa revelou também que, sob o ponto de vista de critérios, métodos e técnicas a serem adotados na construção de Ambientes Virtuais de Aprendizagem, há a incorporação de metodologias típicas do campo da Engenharia de Produção e da Administração. 


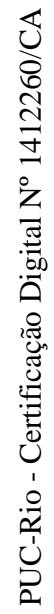




\section{5 \\ Configurabilidade e multimodalidade em Ambientes Virtuais de Aprendizagem}

O presente capítulo tem como finalidade promover uma análise em alguns Ambientes Virtuais de Aprendizagem com o intuito de classificá-los e categorizálos pelo viés da configurabilidade e multimodalidade. O foco é demonstrar por meio de uma breve análise as particularidades que os ambientes apresentam que os tornam mais suscetíveis à flexibilização, à adaptabilidade e à possibilidade de estimular o uso de gêneros multimodais. Nesse intento, será possível elucidar alguns parâmetros e/ou critérios possíveis que podem colaborar em processos de classificação ou categorização de Aprendizagem Virtual de Aprendizagem.

Buscaremos elencar elementos que contribuam para a compreensão do funcionamento de AVAs com vistas a aprimorar ações que potencializem processos e estratégias educacionais. O nosso foco é discutir acerca de parâmetros e conceitos que viabilizem a classificação de ambientes como configuráveis ou não configuráveis, além de tentar identificá-los em suas potencialidades em favorecer à prática de linguagem multimodal. Tem-se como propósito, por meio dessa análise, atender ao quarto objetivo específico desta pesquisa: apresentar uma sistematização das possibilidades e características de (configuração e não configuração) em AVAs.

Para tanto, foi realizada uma verificação dos parâmetros supracitados (configurabilidade e multimodalidade) em alguns dos ambientes mais utilizados internacionalmente. Buscou-se eleger como mote dessa elaboração de critérios uma abordagem no qual se enfatizam os processos de construção de conhecimento centrado no estudante-usuário.

Cabe destacar que a análise que aqui se apresenta é conduzida mais como uma verificação "objetiva” das características dos AVAS do que, propriamente, uma verificação "qualitativa", que necessariamente demandaria uma avaliação do ambiente em situações de uso. A análise de ambientes em situações de uso (construção de aulas) será apresentada no capítulo 6. Assim sendo, no presente 
capítulo não se encontra uma perspectiva de "pesquisador-visitante" dos AVAs. A análise baseia-se na identificação de recursos, na visualização de funcionalidades e acesso a documentos e registros fornecidos por desenvolvedores de Ambientes Virtuais de Aprendizagem.

A seleção de Ambientes Virtuais de Aprendizagem analisados neste capítulo contempla aqueles que possuem maior quantidade de usuários de acordo com o diretório Capterra (2017) e considera os que despontam como mais utilizados conforme o Qs World University Rankings, descrito e exposto no capítulo 3. Neste caso, compõem-se para esta análise cinco AVAs: Moodle, Blackboard, EDX, Coursera e Edmodo.

\section{1}

\section{A configurabilidade em Ambientes Virtuais de Aprendizagem}

Com o intento de reconhecer a configurabilidade em Ambientes Virtuais de Aprendizagem, passamos a verificar a escala de possibilidade de configuração em tais ambientes. Notadamente, alguns ambientes apresentam menor ou maior grau de configuração, acarretando, assim, diferenças no planejamento, na preparação ou na adequação das propostas de ensino. Admitimos como premissa que os recursos e funcionalidades (in)disponíveis em determinadas situações de formação a distância tendem a direcionar, restringir ou ampliar as possibilidades educativas.

Consideramos aqui o fato de que a presença ou a ausência de flexibilidade na configuração de ambientes condiciona as possibilidades e alternativas na elaboração de estratégias favoráveis à qualidade em processos de ensinoaprendizagem. Também reconhecemos que a interação entre educandos, educadores e conteúdo está estritamente relacionada à seleção e utilização de recursos adequados aos processos educativos. No entanto, é também válido destacar que o sucesso que surge em determinadas práticas dependerá não apenas dos recursos, mas também das estratégias de envolvimento dos usuários e estímulos propiciados durante as situações de uso.

Utilizamos o conceito "configuração" de modo a diferenciar de iniciativas de "customização" ou "personalização" de ambientes, sendo que estas últimas ações estão diretamente associadas a uma prática de ajustes e de alterações apenas na aparência dos ambientes. 
Os ambientes que apresentam amplas possibilidades de configuração, além de uma maior flexibilidade em atendimento às demandas dos usuários, também permitem maior versatilidade em propostas e tipos de cursos a serem ofertados. No entanto, é importante considerar alguns possíveis riscos e desafios que tal configurabilidade pode apresentar.

Notadamente, aqueles Ambientes Virtuais de Aprendizagem que dispõem de uma ampla flexibilidade tendem a ser mais complexos e mais difíceis de serem produzidos. Em alguns casos, inclusive, podem demandar custos mais elevados. Outro entrave que pode surgir na proposição de ambientes muito flexíveis e configuráveis é a necessidade de se contar com a ajuda de especialistas em informática para realizar as configurações em tais ambientes.

Humble \& Farley (2014) alertam quanto às características que envolvem a configurabilidade:

O desejo de obter flexibilidade pode levar a um antipadrão comum, chamado de "extrema configurabilidade", que frequentemente é considerado um requisito em projetos de software. [...]. Quanto mais configurabilidade você pretende oferecer aos usuários, menos limitações podem ser introduzidas na configuração do sistema, e mais sofisticado o ambiente de programação precisa ser. (Humble; Farley, 2014, p.40)

Iniciando nossa análise, temos os ambientes Moodle e Blackboard, que possuem características similares no que tange à interface principal e às funcionalidades. Algumas das principais funcionalidades presentes nesses dois ambientes já apresentamos no capítulo 2 desta pesquisa. Lembramos que eles foram concebidos em épocas próximas: o Moodle em 2001, pelo educador e cientista computacional Martin Dougiamas, e o Blackboard Learn, que é um ambiente de aprendizagem virtual, pela empresa Blackboard Inc., em 1997.

O Moodle é classificado como uma plataforma virtual em constante desenvolvimento. O projeto vem sendo construído e disponibilizado gratuitamente de modo colaborativo por uma comunidade virtual da qual participam programadores, desenvolvedores de software livre, administradores de sistemas, educadores, designers e usuários de todo o mundo. Por ser um software com código fonte aberto, qualquer usuário pode estudar, modificar e distribuir o software de graça para qualquer um e para qualquer finalidade. Inúmeras instituições realizam adaptações e utilizam o Moodle não apenas para a oferta de cursos totalmente 
virtuais, mas também como apoio aos cursos presenciais. Se comparado com o Blackboard, é possível admitir que o Moodle possui maior configurabilidade, pelo fato de possuir código fonte aberto.

A Figura 3 apresenta a tela de Configurações da Página Principal do ambiente Moodle, a partir do login de acesso como administrador da plataforma:

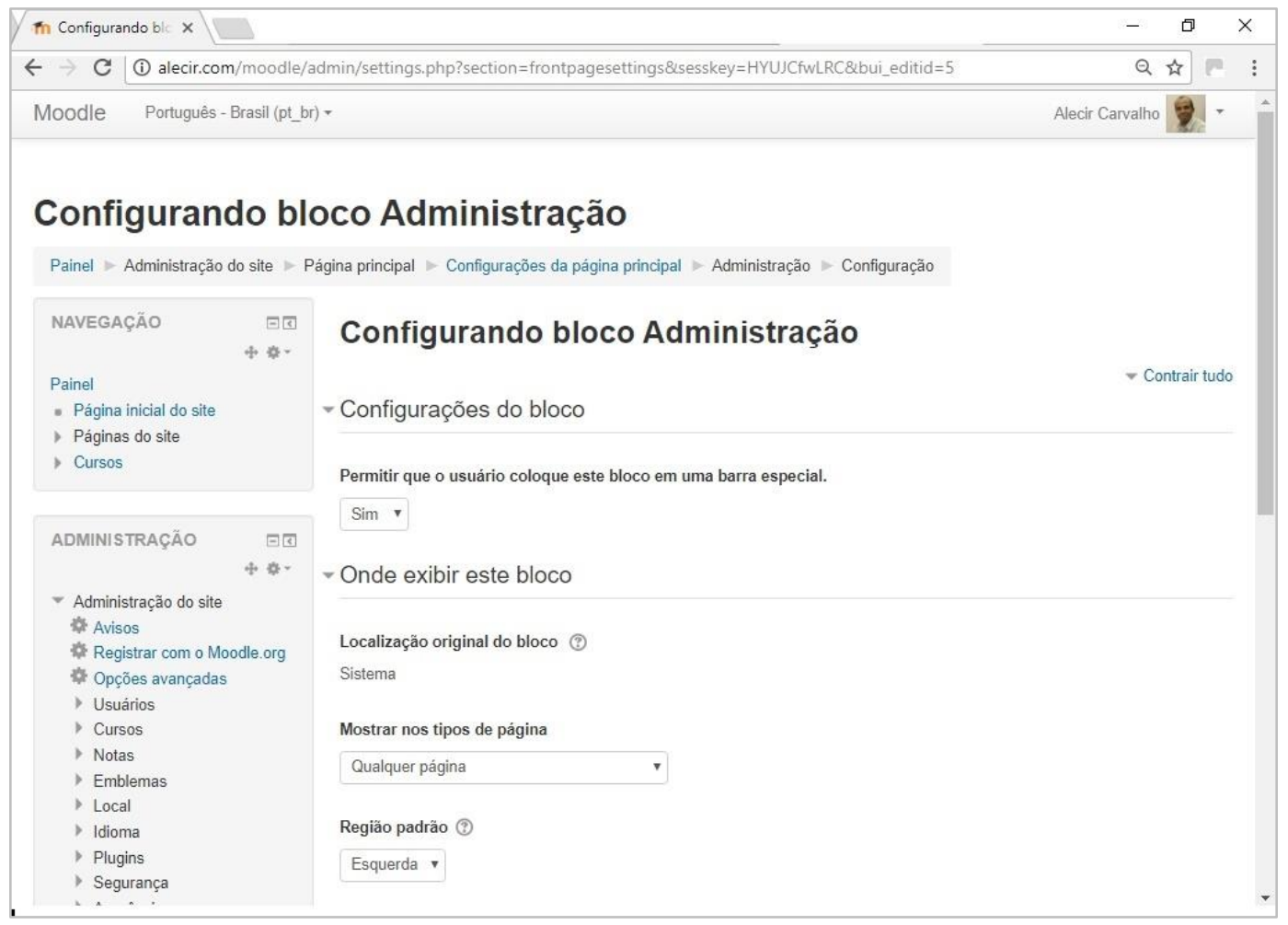

Figura 3 - Tela de configurações da página principal do ambiente Moodle Fonte: Moodle (2015).

O Blackboard é um Ambiente Virtual de Aprendizagem de caráter proprietário, que apresenta possibilidade de configuração, porém com mais restrições em sua estrutura. Os materiais a serem disponibilizados no ambiente Blackboard são organizados de forma hierárquica e, de modo geral, disponibilizados em um menu à esquerda do painel principal. A Figura 4 mostra uma das páginas iniciais do Blackboard, com o menu de funcionalidades disposto na lateral esquerda. 


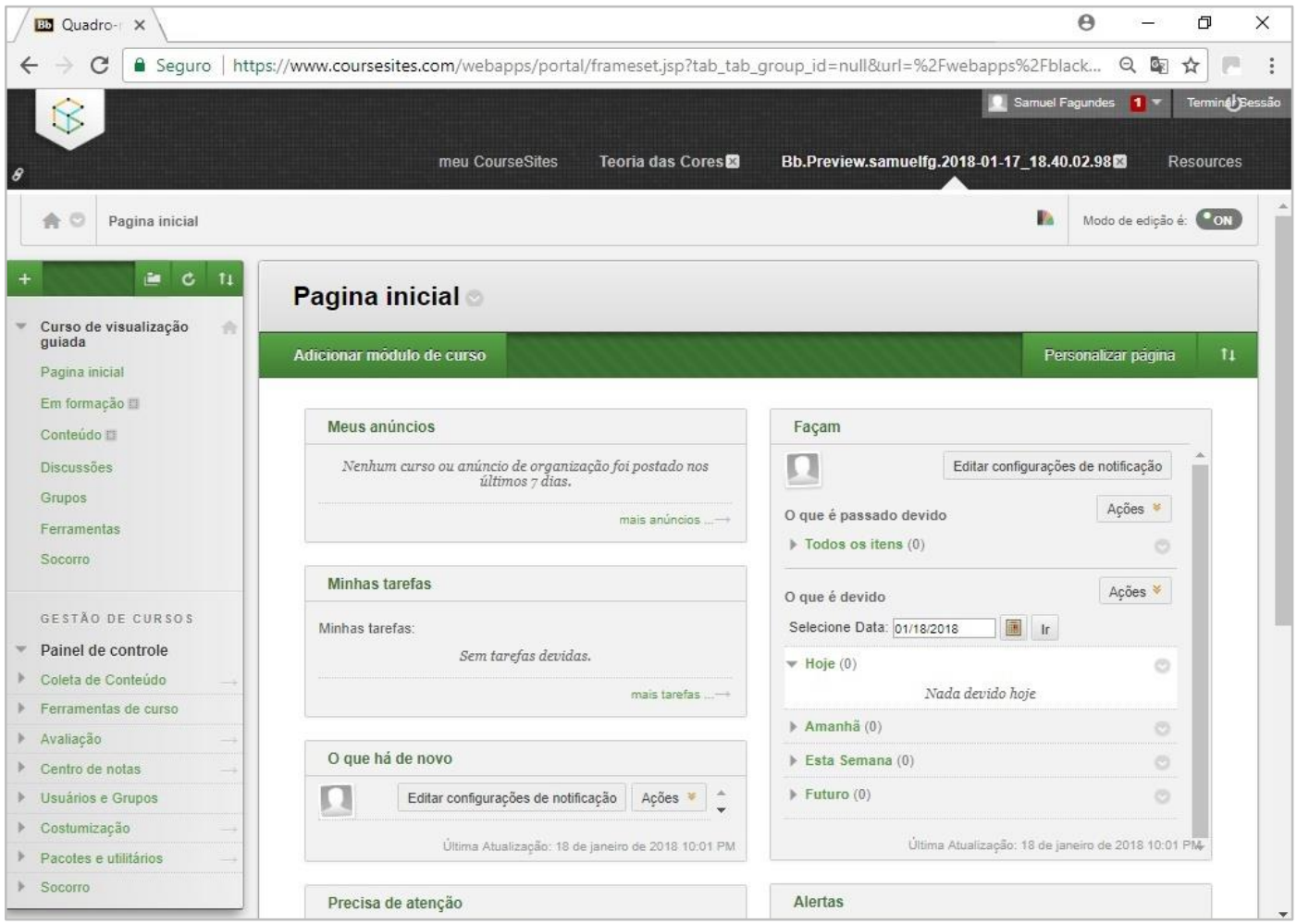

Figura 4 - Páginas iniciais do ambiente Blackboard Fonte: Course Sites (2017).

Podemos reconhecer a existência de similaridades entre o Moodle e o Blackboard no que se refere às funcionalidades disponíveis. Entre os principais recursos similares encontramos: Fórum de Discussão, Questionário, Wiki, Glossário, Chat, Tarefas (entrega de atividades), Blogs, Calendário, entre outros.

Algumas das muitas funcionalidades presentes nos ambientes Moodle e Blackboard podemos observar na Figura 5. 

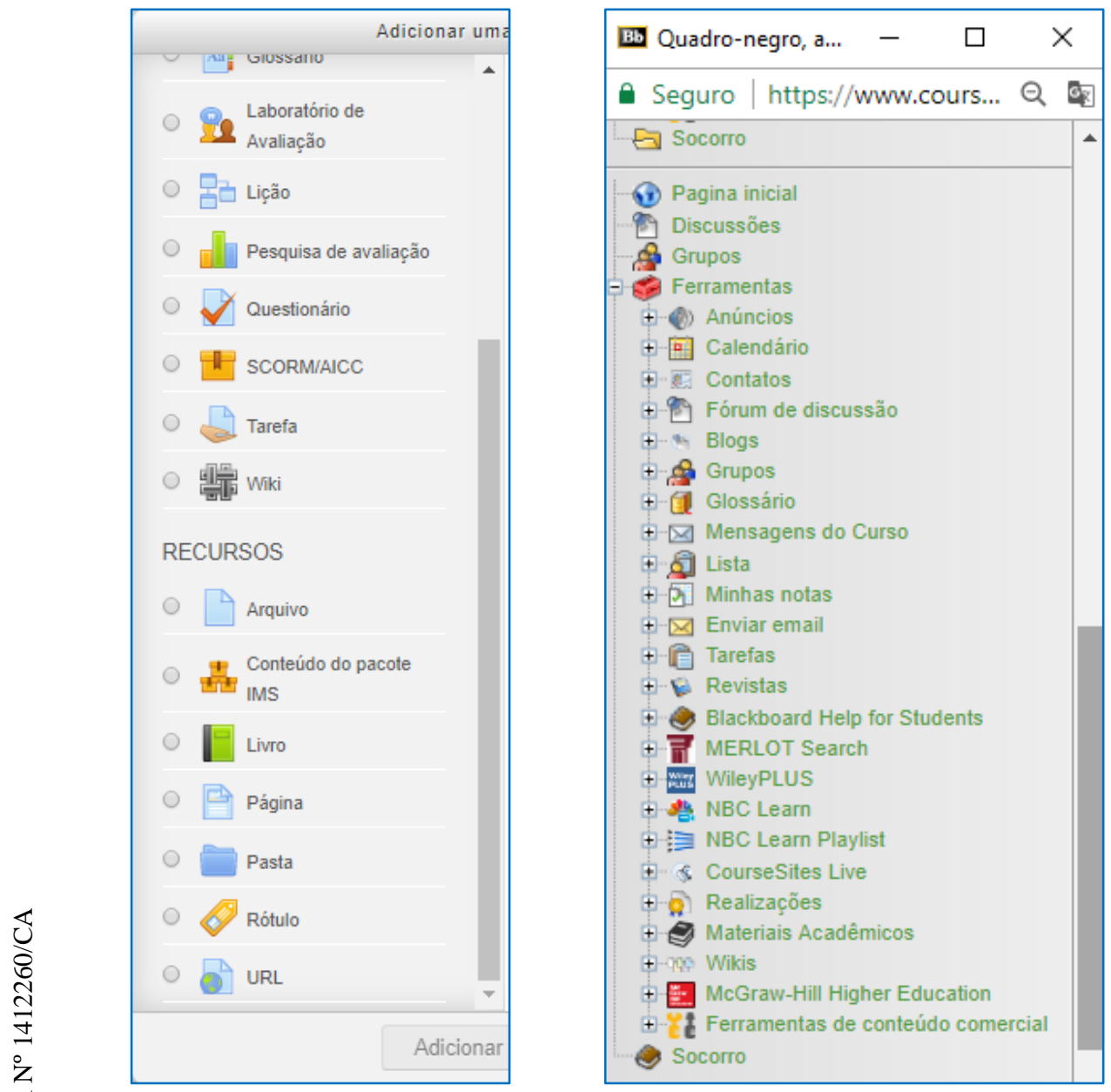

Figura 5 - Janela com as funcionalidades dos ambientes Moodle e Blackboard Fonte: Course Sites (2017).

É possível considerar que o Moodle e o Blackboard integram as primeiras gerações que surgiram de Ambientes Virtuais de Aprendizagem. Ao longo dos anos passaram por inúmeras atualizações que permitiram sua permanência nos períodos atuais.

Já outros ambientes, tais como o EDX e Coursera, possuem características muito distintas. Eles pertencem a outra geração de AVAs, sendo concebidos essencialmente em atendimento à oferta de cursos massivos a distância, os quais têm como premissa o estudo autônomo do estudante. De modo geral, nesse tipo de curso prevalece uma dinâmica de avaliação das tarefas por colegas, que se avaliam mutuamente. Nesses tipos de cursos há uma organização do ensino de modo sequencial e hierarquizado.

Nas Figuras 6 e 7 temos as telas iniciais dos ambientes EDX e Coursera: 


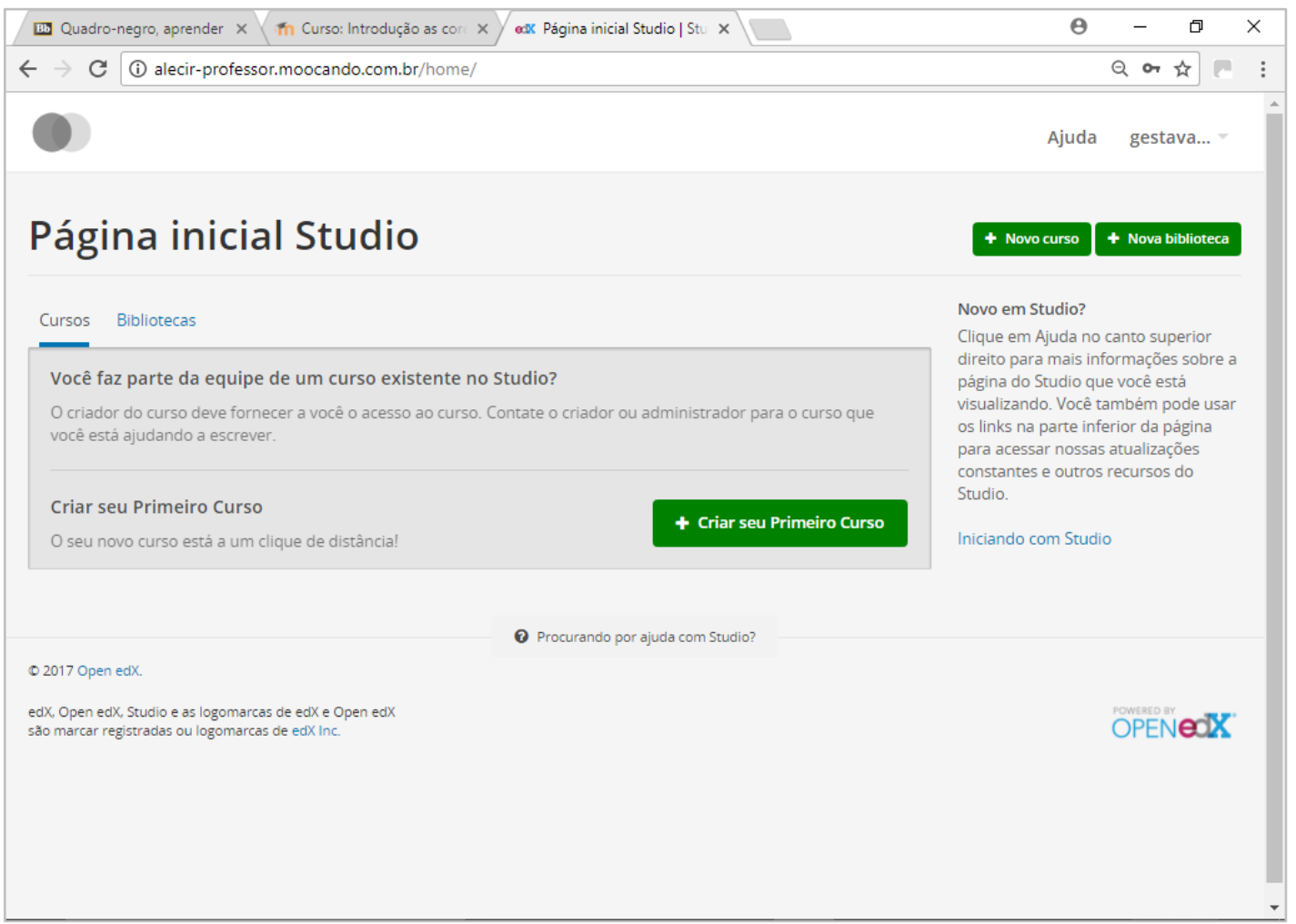

Figura 6 - Página inicial do ambiente EDX com login de criador de curso Fonte: EDX (2015).

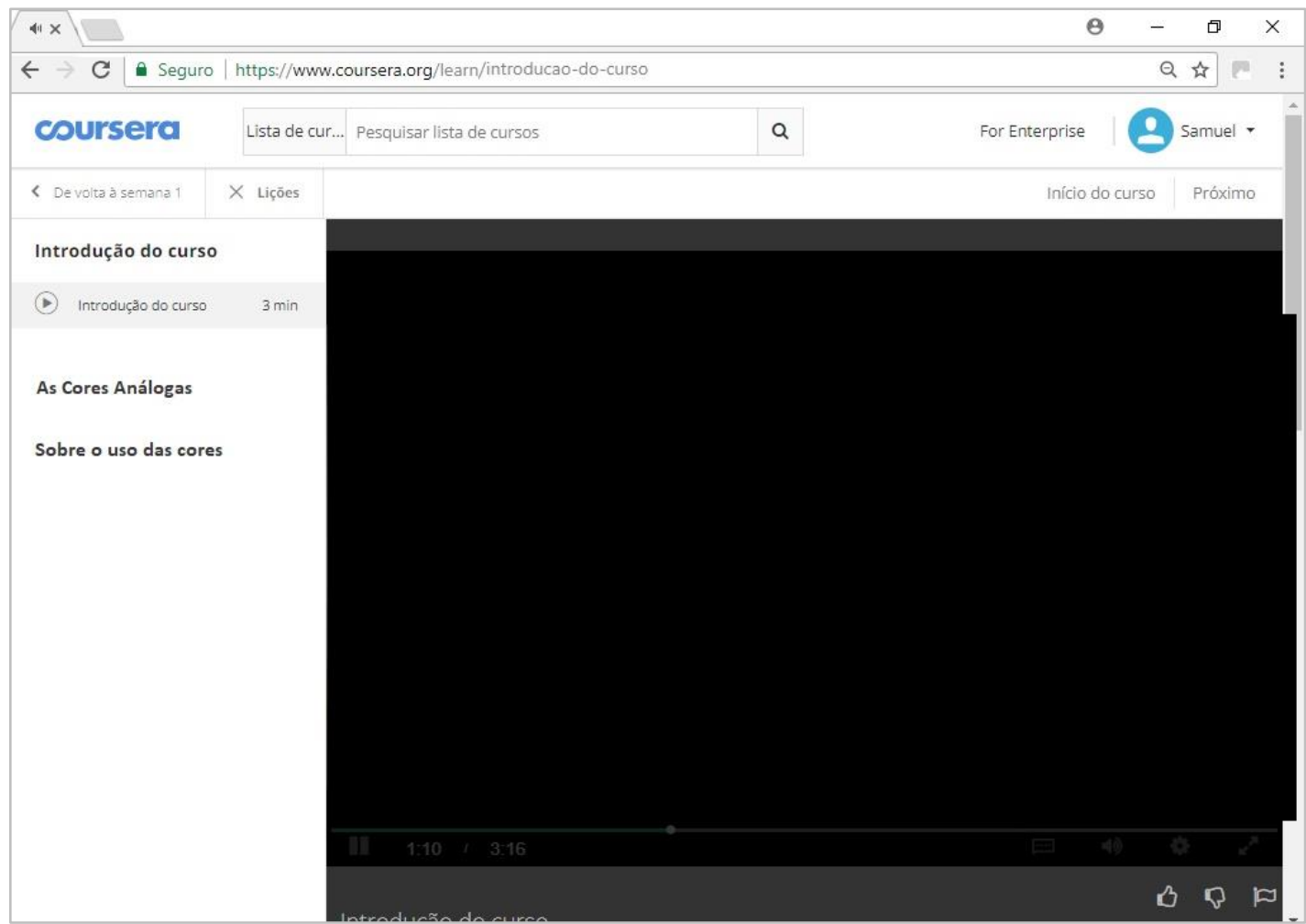

Figura 7 - Página inicial do ambiente Coursera com login de estudante Fonte: Coursera (2015). 
Considerando os propósitos dos ambientes EDX e Coursera, é possível reconhecer as restrições quanto ao grau de configuração. Nesses ambientes, as funcionalidades disponíveis estão no âmbito da inserção de vídeos, textos, fóruns de discussão, além de testes (questionários) e hiperlinks.

Em ambientes dedicados a cursos massivos, tais como o EDX e Coursera, não há a possiblidade da interação em tempo real entre educadores e educandos e educandos e colegas. Sendo assim, não se encontram disponíveis nesses ambientes recursos para a inserção de chat e de videoconferência (ferramentas síncronas). As interações ocorrem essencialmente entre materiais, conteúdos e na participação de educandos nos fóruns de discussão (ferramentas assíncronas), não havendo espaço para oportunamente ocorrerem processos de mediação pedagógica por meio da intervenção de tutores e educadores durante o curso.

Há uma diferença substancial entre o EDX e o Coursera pelo fato de que o EDX disponibiliza o seu código-fonte de modo aberto e gratuito aos usuários. Com o código-fonte aberto, é possível que qualquer instituição, grupo ou indivíduo instale e utilize a estrutura da plataforma para oferecer cursos via internet. Já o Coursera, no entanto, não disponibiliza seu código-fonte, sendo hospedado em servidor de internet próprio, não sendo possível apresentar alguma versatilidade na configuração.

Outros ambientes, tais como o Edmodo, possuem uma estrutura diferente dos quatro ambientes supracitados. Ele foi concebido para ser uma rede social de aprendizagem. Trata-se de um ambiente que pode ser utilizado para facilitar a interação entre educadores e educandos, além da possibilidade de incluir colaboradores, especialistas em determinados assuntos e pais de educandos em discussões promovidas nos grupos ou turmas.

$\mathrm{O}$ ambiente Edmodo possui uma interface que se assemelha à rede social Facebook. Oferece funcionalidades que permitem publicar e compartilhar imagens, textos, arquivos de áudio e vídeo. De modo geral, vem sendo utilizado na atualidade em propostas de cursos a distância e também em formatos de educação híbrida, que se caracteriza por mesclar dois modos de ensino: o presencial e o a distância.

A Figura 8 apresenta a tela principal do ambiente Edmodo: 


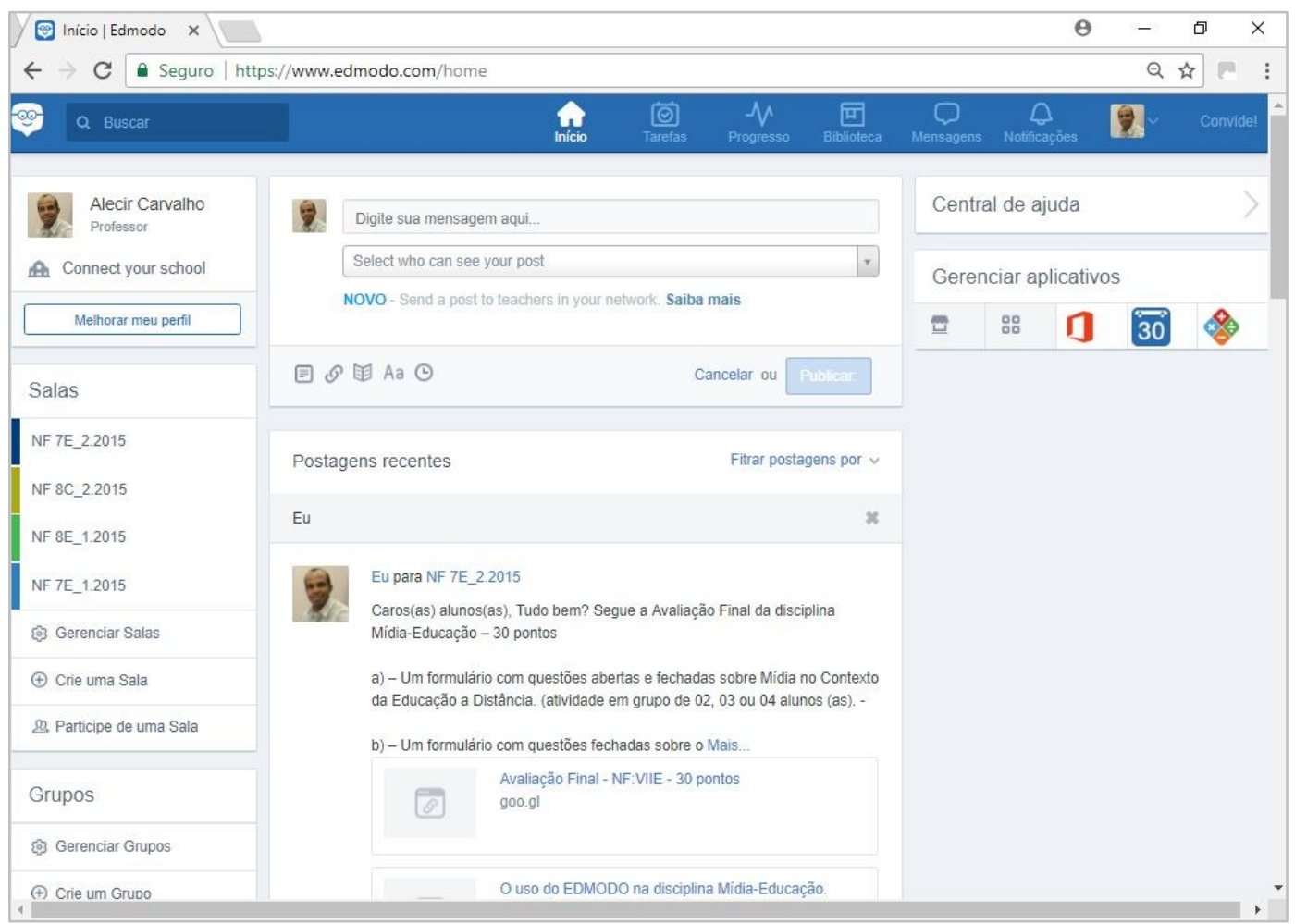

Figura 8 - Tela Principal do ambiente Edmodo Fonte: Edmodo (2015).

Notadamente, as possibilidades de configurações no ambiente Edmodo são inexistentes, pois se trata de um recurso com características padronizadas e sendo hospedado em servidor de internet próprio, inviabilizando a flexibilidade e as possibilidades de (re)configurações.

Assim sendo, é possível agruparmos os cinco Ambientes Virtuais de Aprendizagem apresentados considerando três categorias: na primeira, é possível alocarmos os ambientes Moodle e Blackboard por suas similaridades de concepção e funcionalidades que abrangem o uso de ferramentas síncronas e assíncronas. $\mathrm{Na}$ segunda, é possível alocarmos os ambientes EDX e Coursera dedicados a cursos massivos a distância que não possibilitam intervenções e mediações em tempo real. E, finalmente, uma terceira categoria, em que podemos alocar o Edmodo como uma rede social educacional com princípios e propósitos distintos dos quatro anteriores.

\section{2}

\section{A multimodalidade em Ambientes Virtuais de Aprendizagem}

Nesta subseção, temos o intento de verificar as potencialidades de Ambientes Virtuais de Aprendizagem em propiciar e estimular o uso de gêneros multimodais. 
Para tanto, nos reportamos aos estudos promovidos por Tanzi Neto \& Lessa (2014), direcionados à análise de Ambientes Virtuais de Aprendizagem sob a ótica dos estudos bakhtinianos. Os autores supracitados promoveram uma pesquisa em que se buscou avaliar duas ferramentas disponíveis (Fórum de Discussões e Mural de Postagens) em dois Ambientes Virtuais de Aprendizagem: o Teleduc e o Edmodo.

Oportunamente, buscaremos discutir e analisar preliminarmente, sob a ótica de Mikhail Bakhtin, alguns aspectos relacionados ao uso de gêneros multimodais em alguns Ambientes Virtuais de Aprendizagem. É possível considerar, neste sentido, o surgimento de inúmeras práticas de linguagem que emergem a partir do uso das tecnologias digitais de informação e comunicação no cenário contemporâneo.

Sendo assim, escolhemos fazer nossa breve análise em uma funcionalidade geralmente disponível em Ambientes Virtuais de Aprendizagem em que se dão as discussões entre educador-educando e educando-colegas. No Moodle, o nome é Fórum; no Blackboard, assume o nome de Fórum de Discussão; no EDX e Coursera, apenas o nome de Discussão. Já no Edmodo, temos a funcionalidade Mural de Postagens.

No Moodle e no Blackboard, os recursos Fórum e Fórum de Discussão possibilitam o acesso a uma página específica do ambiente em que estarão disponíveis discussões organizadas em tópicos criadas por educadores ou tutores. A apresentação das discussões ocorre de forma estruturada, permitindo a visualização das mensagens já postadas e possibilitando o (re)envio de respostas e novas mensagens, organizadas em tópicos. No Fórum e no Fórum de Discussão, é possível a inserção de textos, imagens, arquivos de áudio e vídeo, podendo ser inseridos tanto por meio de links ou incorporados no próprio campo das mensagens, na função "embedded" (embutido).

As imagens a seguir (Figuras 9 e 10) apresentam as telas correspondentes ao Fórum e ao Fórum de Discussão: 


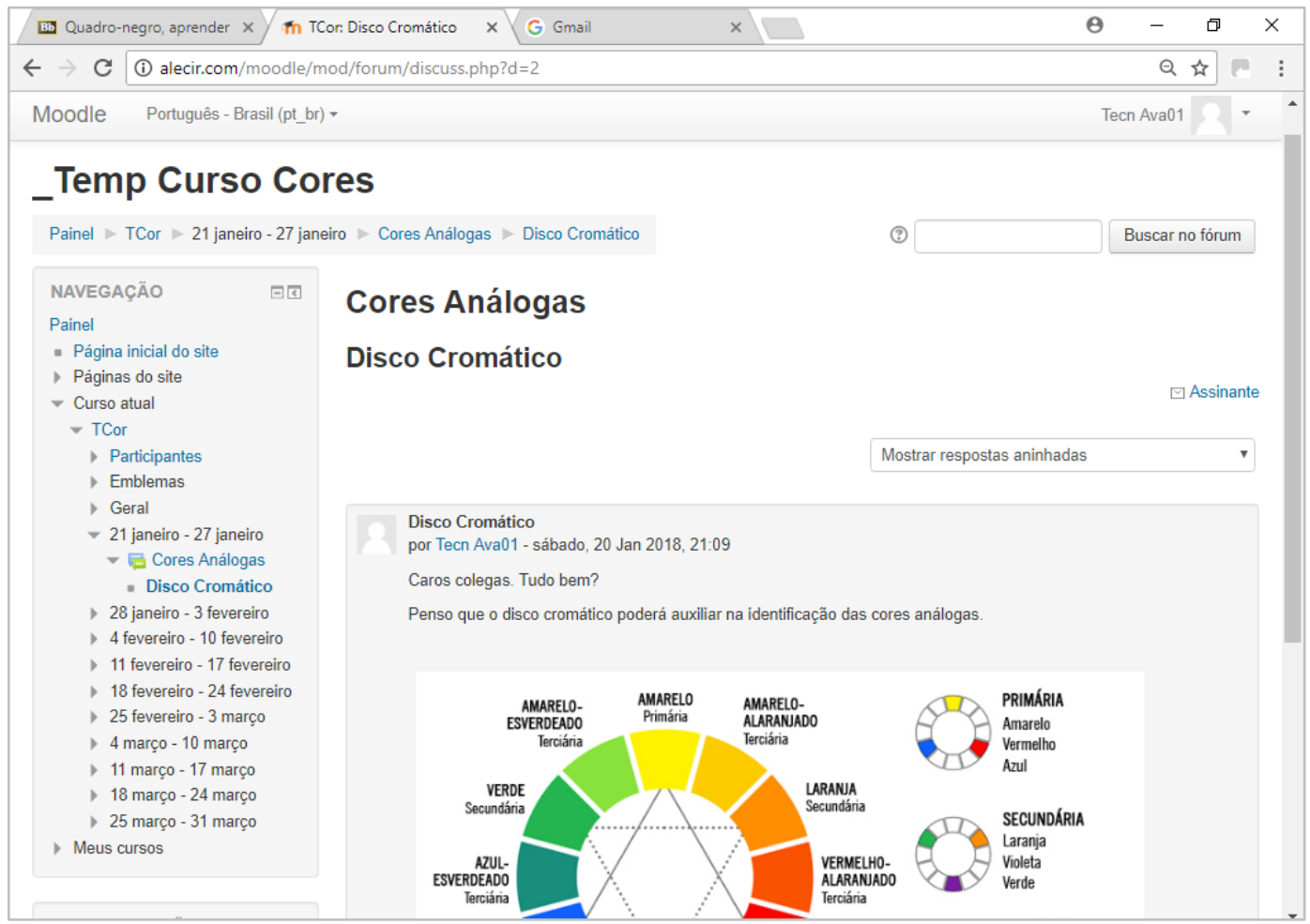

Figura 9 - Tela do recurso Fórum de Discussão no Moodle Fonte: Moodle (2015).

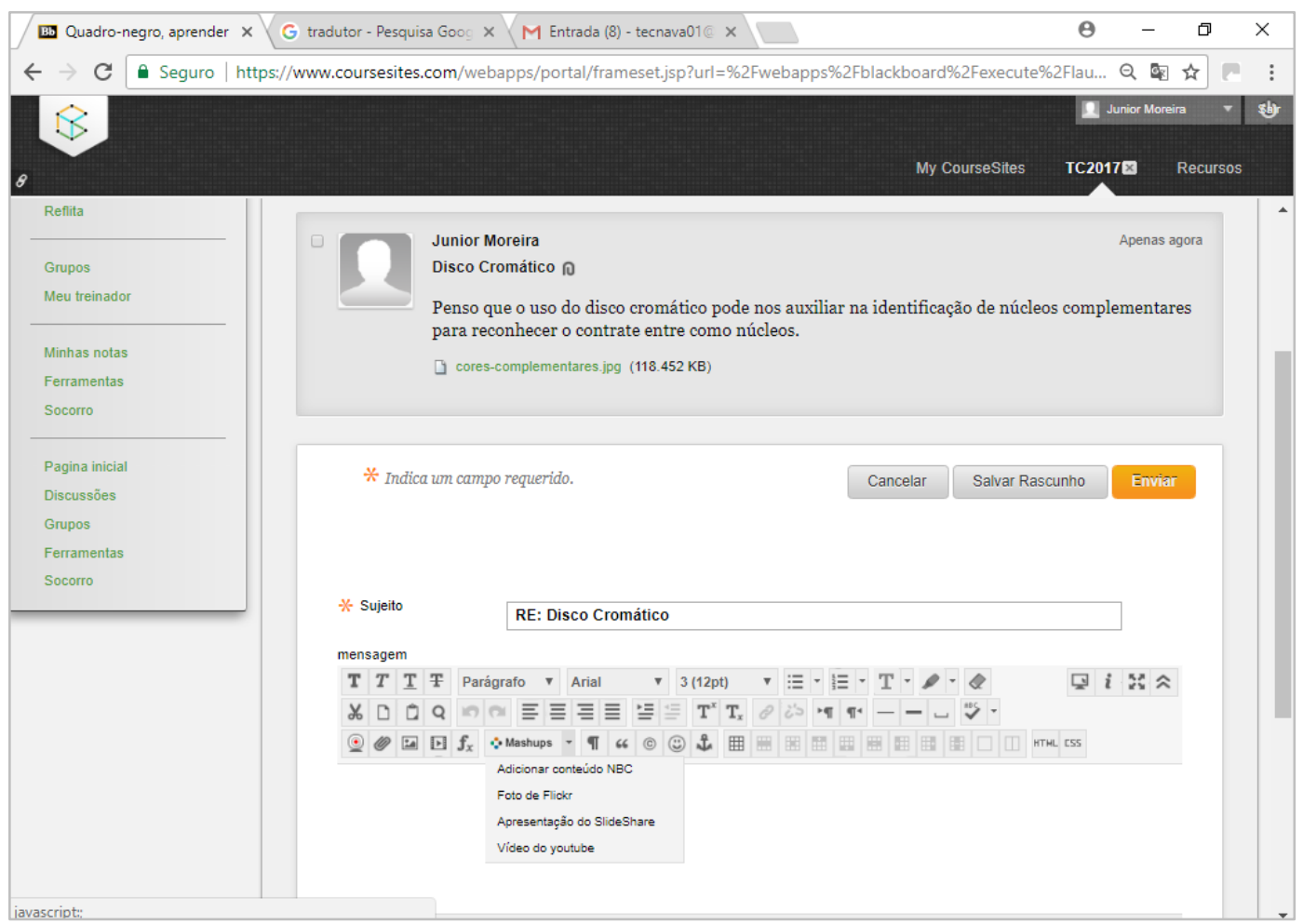

Figura 10 - Tela do recurso Fórum no Blackboard Fonte: Course Sites (2017).

Um recurso importante disponível nos ambientes Moodle e Blackboard é a possibilidade de inserir emojis. Os emojis são figuras introduzidas nas mensagens 
digitais, pelo sistema Unicode, que possibilitam aos usuários manifestarem e expressarem emoções um para o outro. Alguns autores, tais como Paiva (2016), sinalizam os impactos que os emojis são capazes de proporcionar no âmbito da linguagem humana. Segundo a autora citada, temos que concordar que o uso dos emojis "indicam que a linguagem escrita informal está cada vez mais multimodal com a inserção dessas representações visuais". (Paiva, 2016)

No Moodle e no Blackboard, é possível utilizar alguns emojis disponíveis nas funcionalidades Fórum e Fórum de Discussão, os quais nos referidos ambientes são apresentados na Figura 11:
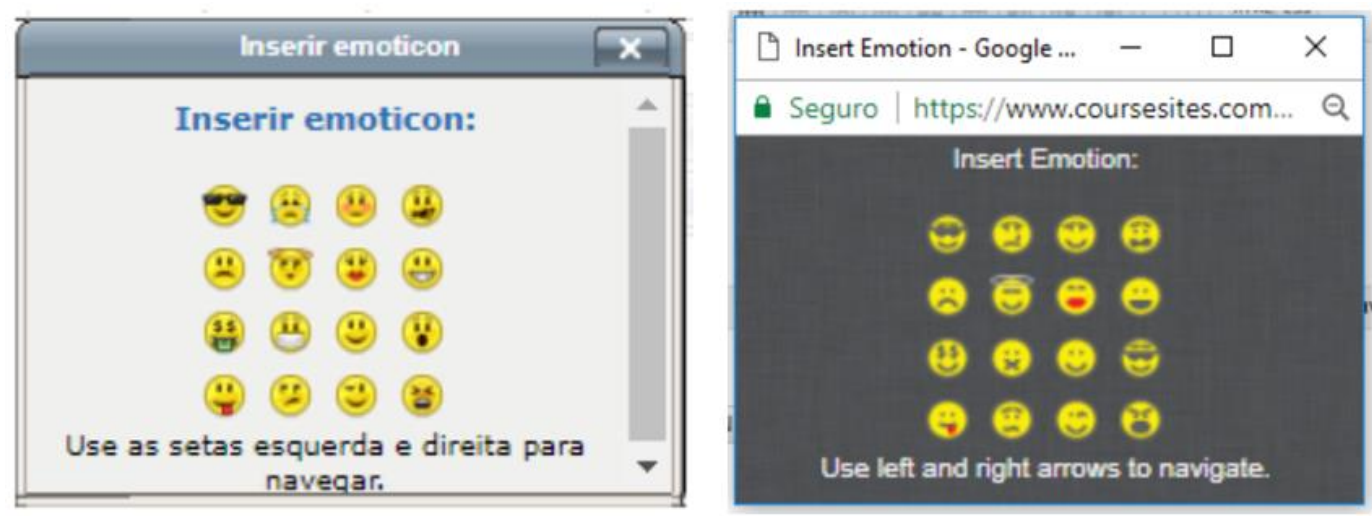

Figura 11 - Emojis disponíveis no Moodle e Blackboard Fonte: Course Sites (2017).

No caso dos ambientes EDX e Coursera, o recurso Discussão apresenta limitações, se comparado aos ambientes Moodle e Blackboard. A organização das discussões se dá de forma linear e hierarquizada, no formato de atividade a ser realizada pelos educandos. É permitida a inserção de textos, imagens e links. Não há possibilidade de incorporar áudio ou vídeo no próprio campo das mensagens, na função "embedded" (embutido). Neste caso, a inclusão de links direcionará o usuário para fora do ambiente virtual de aprendizagem, em uma nova guia.

As Figuras 12 e 13 apresentam as telas correspondentes ao recurso Discussão nos ambientes EDX e Coursera. 


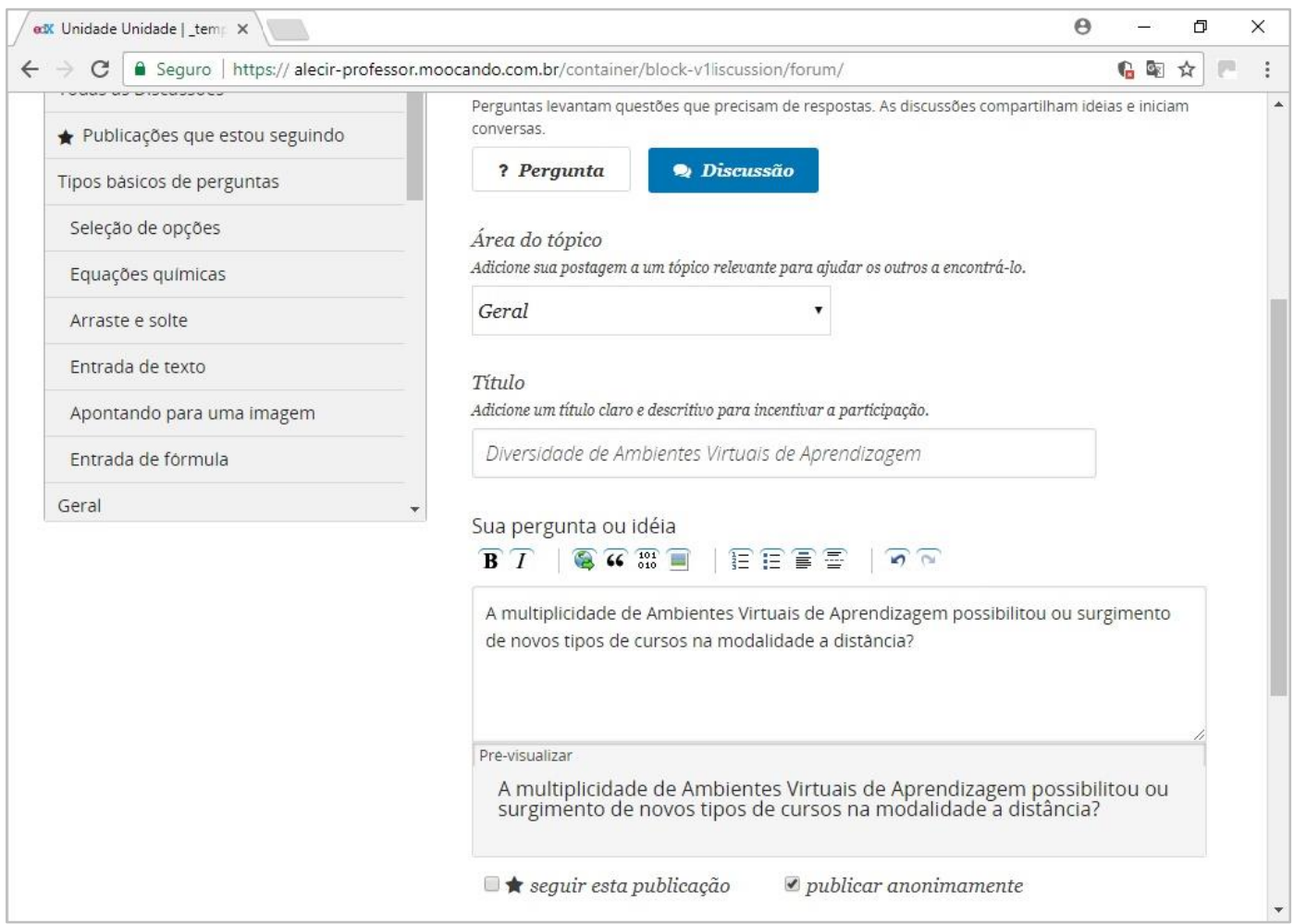

Figura 12 - Tela do recurso Discussão no EDX Fonte: EDX (2015).

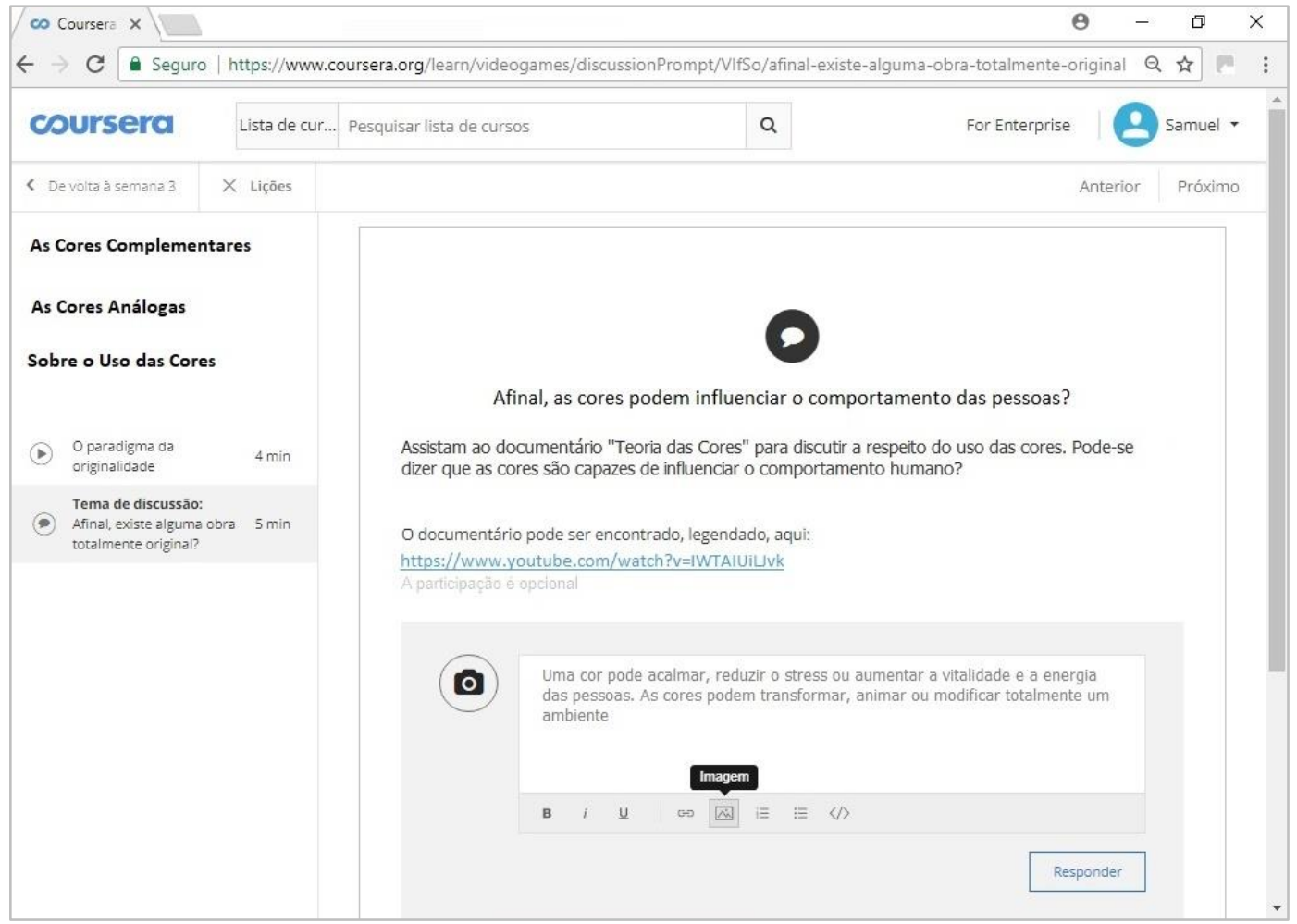

Figura 13 - Tela do recurso Discussão no Coursera Fonte: Coursera (2015) 
No EDX e no Coursera, não há a função inserir emojis, restringindo a possibilidade de comunicação e expressão multimodal por usuários desses dois ambientes.

Já numa análise do ambiente Emodo, encontramos o recurso Mural de Postagens, que substitui os recursos Fórum, Fórum de Discussão e Discussão dos quatro ambientes já citados. No Edmodo, o Mural de Postagens é local onde se dá as discussões de conteúdo entre educadores-educandos e educandos-colegas. Nele é possível fazer comentários, inserir imagens, emojis, arquivos de áudio, vídeo e apresentações de slides. No Mural de Postagens está disponível aos usuários a opção de incorporar imagens e vídeos no próprio campo das mensagens, na função "embedded" (embutido).

Conforme já apresentado em capítulos anteriores, nesta pesquisa, o Edmodo possui uma interface que se assemelha à rede social Facebook. Na sua página inicial está localizado o espaço de discussão e colaboração no ambiente. O estímulo e incentivo à discussão destacam-se no Edmodo (Figura 14).

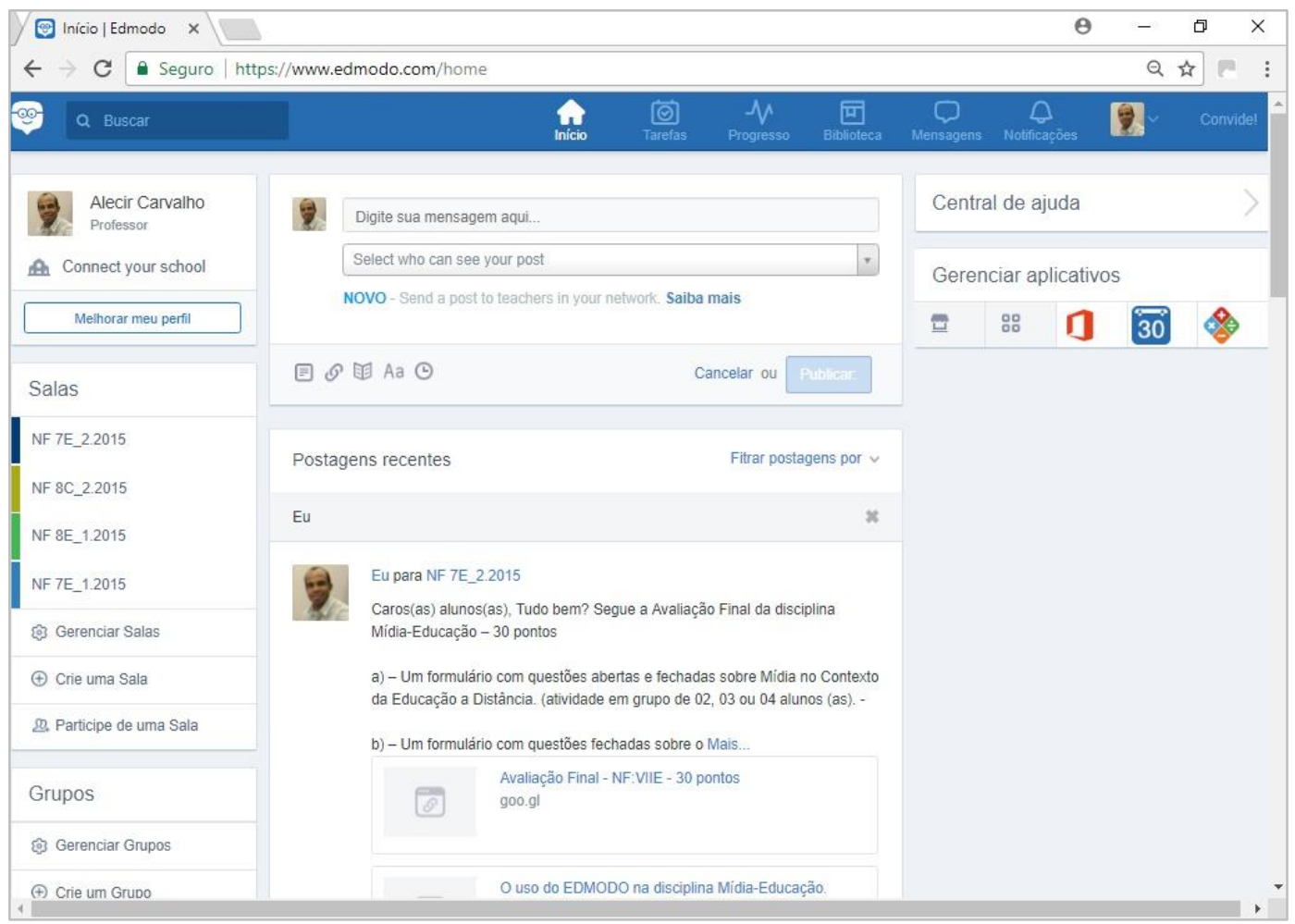

Figura 14 - Tela Inicial do Edmodo Fonte: Edmodo (2015). 
Pelo fato de o Edmodo ser uma rede social educativa, notamos a disponibilidade de alguns recursos que se assemelham à maioria das redes sociais. Logo abaixo, na região inferior das postagens dos usuários, têm-se as opções de Curtir, Responder, Compartilhar e/ou Seguir (Figura 15).

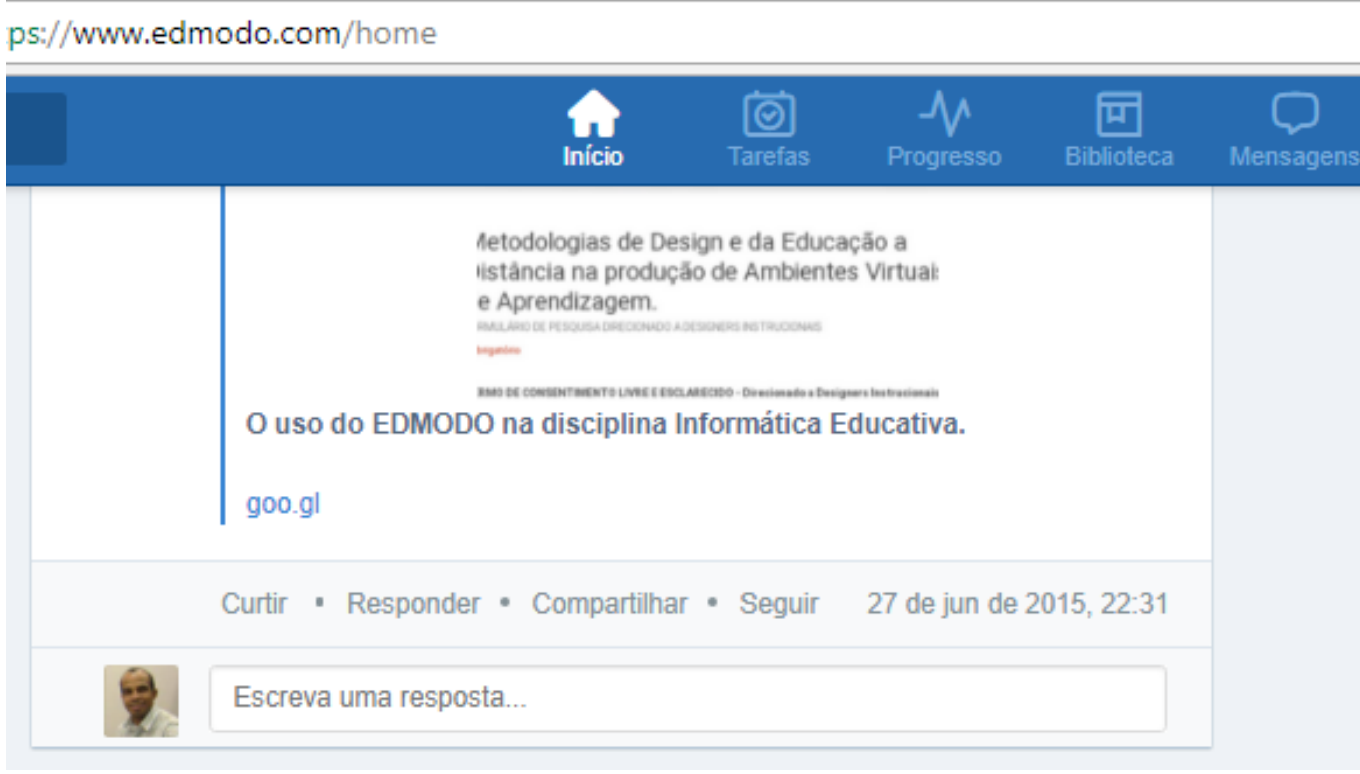

Figura 15 - Opções de ações no Edmodo Fonte: Edmodo (2015).

Diante dessas observações, reconhecemos que no Edmodo priorizam-se as postagens dos usuários e a promoção de discussões acerca das temáticas e conteúdos abordados no ambiente.

\section{3 Considerações parciais acerca da configurabilidade e da multimodalidade em Ambientes Virtuais de Aprendizagem}

A partir da breve análise aqui apresentada, foi possível constatar que os ambientes Moodle e Blackboard apresentam características mais flexíveis quanto à configuração de seu layout e disponibilidade de funcionalidades. Considera-se, de modo especial, que a flexibilidade de código aberto do Moodle possibilita a configuração sob demanda pelos gestores dos cursos, de modo a viabilizar uma interface gráfica simples e amigável aos tutores e educandos-usuários. Os ambientes Moodle e Blackboard oferecem a possibilidade de organização do espaço de modo personalizável, tanto na inserção de recursos e funcionalidades quanto na 
colocação das atividades dos cursos. Há certa facilidade de consulta de materiais, atividades e postagens feitas em longo prazo.

Já os ambientes EDX e Coursera e Edmodo são propostas com menor margem de configuração. Nesses há restrições na reconfiguração e organização do espaço, e, de modo particular no Edmodo, há ainda certa dificuldade em localizar atividades e materiais postados em longo prazo em virtude da sobreposição de postagens na Linha do Tempo (Timeline).

Nos ambientes Moodle e Blackboard há várias alternativas para a avaliação do aprendizado dos educandos, além da possibilidade de visualização detalhada das notas. Em contrapartida, no Edmodo, há limites no detalhamento de notas atribuídas aos educandos. Contudo, o ambiente similar ao das redes sociais favorece ações de compartilhamento, comentários e curtidas das postagens de educadores e educandos.

No âmbito da multimodalidade nos ambientes avaliados, foi possível constatar que os cinco ambientes analisados oferecem uma diversidade de opções no que se refere às possibilidades de comunicação. Por meio do uso dessas diferentes opções nas funcionalidades Fórum, Fórum de Discussão, Discussão e Mural de Postagens, reconhecemos que se trata de uma ferramenta multimodalmente constituída, e não somente alfabética.

A partir de nossa análise preliminar descritiva e comparativa dos ambientes, foi possível perceber o destaque para os ambientes Moodle e Blackboard, que disponibilizam ao usuário a opção de inserir vídeos e arquivos de áudio, incorporados à página, sem a necessidade de links externos. Ademais, nesses dois ambientes encontramos a possibilidade de incluir emojis, proporcionando uma maior interação verbal humana. 


\section{6 \\ Concepções, significados e sentidos atribuídos aos Ambientes Virtuais de Aprendizagem}

Neste capítulo, apresentamos os resultados de uma experimentação realizada no formato de simulação de uso por nove usuários, realizada em três Ambientes Virtuais de Aprendizagem diferentes. Após a utilização dos ambientes os usuários foram entrevistados sobre sua participação. Foram preparados e disponibilizados três ambientes com características distintas: as plataformas EDX, Moodle e Edmodo. Os usuários tiveram o período de uma semana para construir aulas e atividades nesses três ambientes.

As plataformas foram utilizadas por três grupos diferentes de usuários: o primeiro grupo foi formado por gestores que trabalham ou já trabalharam em cursos ou programas de educação a distância; o segundo grupo foi composto por educadores que não são formados em Design, mas que lecionam em cursos de Design, e o terceiro grupo foi formado por designers, profissionais bacharéis em Design. Desse modo, foi possível conhecer as impressões e percepções desses três grupos acerca do que os Ambientes Virtuais de Aprendizagem oferecem aos usuários.

Este capítulo está em consonância com o quinto objetivo da tese, que é: identificar e entender as concepções, significados e sentidos atribuídos por gestores, educadores e designers aos Ambientes Virtuais de Aprendizagem.

Temos como foco analisar nos discursos dos agentes da $\mathrm{EaD}$ os significados e sentidos que eles atribuem aos Ambientes Virtuais de Aprendizagem. Buscamos também identificar nos discursos desses agentes as possíveis aproximações e distanciamentos entre Design e Educação a Distância no âmbito da construção de AVAs para o aprimoramento de processos educativos.

Privilegiamos a visão bakhtiniana para a análise dos dados coletados durante a pesquisa de campo, com o intuito de melhor compreender os significados e sentidos dos agentes acerca de três AVAs previamente selecionados. 


\section{1 Procedimentos Metodológicos}

A pesquisa é do tipo qualitativa e de caráter exploratório, envolvendo a participação de nove voluntários, os quais, conforme já mencionado, são gestores, educadores e designers. A escolha do perfil de participantes se deu a partir da vinculação ao campo do Design ou ao envolvimento específico com o campo da Educação a Distância.

Para esta pesquisa fizemos a preparação de três ambientes virtuais de aprendizagem distintos, que foram utilizados pelos voluntários. A escolha dos ambientes se deu considerando o agrupamento proposto no capítulo 5, conforme suas características de configurabilidade. Assim, temos o Moodle e o Blackboard em uma primeira categoria, o EDX e o Coursera em uma segunda categoria, e finalmente o Edmodo como um terceiro tipo de ambiente. Fizemos a opção por disponibilizar aos voluntários os seguintes ambientes: Moodle, EDX e Edmodo. Esses dois primeiros foram selecionados por oferecem a facilidade de acesso ao respectivos códigos-fonte para a instalação em servidor de hospedagem na internet. Já o terceiro, o Edmodo, foi escolhido por se apresentar já hospedado em servidor próprio na web e disponível para uso gratuito.

Os ambientes foram disponibilizados aos voluntários em seus formatos nativos, sem nenhum tipo de customização ou personalização. Não houve ajustes nas plataformas EDX e Moodle, para tentar assegurar a aparência padrão e manter condições de igualdade durante a avaliação dos recursos que elas oferecem.

Após realizarmos a preparação dos ambientes, apresentamos aos voluntários as orientações para a participação na pesquisa (Apêndice E). Pedimos que fosse elaborado uma aula com o tema "Estudo sobre as Cores" em cada um dos três ambientes: EDX, Moodle e EDMODO. Este tema foi escolhido por acreditarmos ser uma temática comum e simples de ser desenvolvida nos ambientes. Também afirmamos aos participantes que poderiam optar por não produzir conteúdo, podendo copiar e/ou anexar arquivos disponíveis na internet e incorporá-los às aulas. Enfatizamos que o mais importante era fazer uso das ferramentas em suas potencialidades. Além disso, solicitamos que as aulas, criadas nos ambientes, incluíssem algum recurso/estratégia para a avaliação do aprendizado dos 
educandos. Explicitamos que a nossa proposta era coletar relatos posteriores à utilização dos três ambientes por cada um dos 9 (nove) participantes.

Foi oferecido o prazo uniforme de uma semana a cada um dos nove participantes para também tentar padronizar o tempo de uso. Posteriormente, foram realizadas entrevistas estruturadas, com o intuito de colher dos participantes suas impressões e percepções sobre o uso dos três ambientes. Cada um dos 9 (nove) participantes tiveram a oportunidade de utilizar cada um dos 3 (três) ambientes. As entrevistas tiveram a duração de 30 minutos em média. Foram registradas em gravador digital e posteriormente transcritas na íntegra, para possibilitar o reconhecimento das impressões, significados de cada participante e a fidedignidade das informações.

Os participantes foram informados antecipadamente dos objetivos da pesquisa e concordaram em participar, desde que fossem mantidos no anonimato (Apêndice C). Para tanto, para fins de sigilo, serão denominados, aqui, os três gestores como G1, G2 e G3, os educadores como E1, E2 e E3 e os três designers como D1, D2 e D3.

\section{2}

\section{Análise e interpretação dos dados}

A partir da coleta de dados, buscou-se analisar e interpretar as informações verbalizadas pelos participantes. Para essa análise, os seus depoimentos foram classificados em categorias, com o objetivo de identificar os significados e sentidos atribuídos e verbalizadas pelos entrevistados. As categorias constituídas nesta pesquisa são: a) caracterização dos participantes; b) utilização dos Ambientes Virtuais de Aprendizagem nesta pesquisa; c) avaliação dos Ambientes Virtuais de Aprendizagem nesta pesquisa; d) relação entre Ambientes Virtuais de Aprendizagem e o campo do Design.

Os dados dessa fase foram analisados à luz dos conceitos de significados e sentidos em Bakhtin. 


\subsection{1}

\section{A caracterização dos participantes}

O objetivo de propor essa questão foi identificar a formação e a atuação dos participantes no campo da Educação a Distância e do Design (Apêndice D). Buscamos também verificar as características do contexto de cada participante, assim como as características sociais e históricas com as quais eles interagem. Somado a isso, tivemos o interesse de verificar quais Ambientes Virtuais de Aprendizagem os pesquisados conheciam ou já utilizaram. Ao examinar as respostas que surgiram, foi possível verificar que 6, dentre os 9 entrevistados, possuíam, além da graduação, uma pós-graduação stricto sensu. Os participantes apresentavam, respectivamente, formações acadêmicas, conforme segue:

\begin{tabular}{|c|c|c|}
\hline Participantes & Formação Inicial & Formação Continuada \\
\hline G1 & Licenciatura em Pedagogia & Mestrado em Educação \\
\hline G2 & $\begin{array}{c}\text { Bacharelado em Sistemas de } \\
\text { Informação }\end{array}$ & Mestrado em Design \\
\hline G3 & Bacharelado em Comunicação Social & Mestrado em Design \\
\hline E1 & Bacharelado em Filosofia & Mestrado em Design \\
\hline E2 & Licenciatura em Pedagogia & $\begin{array}{c}\text { Mestrado em Educação } \\
\text { Tecnológica }\end{array}$ \\
\hline E3 & Licenciatura em Pedagogia & Mestrado em Lazer \\
\hline D1 & Bacharelado em Design & Mestrando em Design \\
\hline D2 & Bacharelado em Design & --------- \\
\hline D3 & Bacharelado em Design & --------- \\
\hline
\end{tabular}

Quadro 8 - Formações acadêmicas dos participantes gestores, educadores e designers Fonte: Dados da Pesquisa.

O nosso interesse em convidar participantes que tivessem uma aproximação com o campo do Design ou com o campo da Educação era o de viabilizar o reconhecimento de concepções e impressões dos voluntários numa possível perspectiva de alinhamento, convergência ou distanciamento entre esses dois campos.

Em relação ao tempo de atuação na gestão ou na docência em cursos ou programas em Educação a Distância, os entrevistados gestores e educadores deram as seguintes respostas: quatro anos (G1); seis anos (G2); um ano e seis meses (G3); nunca (E1); seis meses (E2); treze anos (E3). Já os designers puderam sinalizar se já fizeram cursos ou participaram da elaboração de cursos na modalidade a 
distância. Responderam conforme segue: quatro anos atuando na elaboração de materiais para cursos a distância (D1); nunca fez cursos na modalidade a distância e nem participou na elaboração de cursos (D2); atualmente está fazendo um curso a distância na área de gestão financeira com duração de dois anos e meio e é totalmente on-line (D3).

A partir dessas informações, fica evidente o envolvimento de grande parte dos pesquisados em relação à Educação a Distância. Também fica evidente que apenas dois entrevistados ainda não tiveram contato com cursos na modalidade a distância, outros já apresentam uma experiência significativa de treze anos de atuação nesse formato de ensino.

Em se tratando do questionamento feito sobre a atuação dos participantes na configuração ou customização de Ambientes Virtuais de Aprendizagem, apenas os gestores 2 e 3 sinalizaram positivamente quanto a esse tipo de experiência, conforme expressam nos relatos a seguir:

[...] eu instalei a primeira plataforma e também auxiliei na Reitoria, enquanto gerente de informática, na instalação de outros ambientes virtuais, de outras unidades da (Universidade). A gente ajudou a Faculdade [...] com os primeiros ambientes adotados por eles, no caso o Moodle. (G2)

$\mathrm{Na} \mathrm{EaD} \mathrm{eu} \mathrm{fiz} \mathrm{um} \mathrm{pouco} \mathrm{de} \mathrm{construção} \mathrm{de} \mathrm{aula,} \mathrm{um} \mathrm{pouco} \mathrm{de}$ apoio na plataforma Moodle, um pouco de diagramação, um pouco de revisão, neste sentido assim. Especialmente do Moodle nesta ocasião, eu ajudava na configuração dos cursos. Tanto que para mim, usar o Moodle foi mais fácil. (G2)

Com base nas respostas apresentadas, nota-se que a atuação dos gestores entrevistados esteve exclusivamente voltada para a plataforma Moodle. As atuações ocorreram no âmbito da instalação ou no auxílio da configuração dos cursos na referida plataforma. Os dois gestores não expressaram, durante as entrevistas, detalhes sobre uma possível avaliação ou acompanhamento durante os processos de configuração ou customização.

Constatamos também, nos enunciados dos participantes gestores, a alternância de modos de proceder em momentos da experiência de trabalho em que supostamente ocorrem situações realizadas coletivamente e outras individualmente. As expressões "eu instalei" e "eu fiz" se intercalam com as expressões "a gente ajudou" e "eu ajudava". 
Foi perguntado a todos os participantes quais os Ambientes Virtuais de Aprendizagem já utilizaram em cursos de Educação a Distância. Considerando que nem todos os entrevistados fizeram cursos nesta modalidade, as respostas expressam o contato que já tiveram, conforme o Quadro 9:

\begin{tabular}{|c|c|}
\hline Participantes & Ambientes Virtuais de Aprendizagem que já utilizaram \\
\hline G1 & Moodle \\
\hline G2 & Moodle e Plataforma Ânima \\
\hline G3 & Moodle, Coursera e Teleduc \\
\hline E1 & Nenhum \\
\hline E2 & Moodle \\
\hline E3 & Moodle, Ambiente Portfólio (Moodle modificado) \\
\hline D1 & Nenhum \\
\hline D2 & Alternativo (Serviços do Google) \\
\hline D3 & Portal do Aluno (Moodle modificado) \\
\hline
\end{tabular}

Quadro 9 - Identificação dos AVAs que os pesquisados já utilizaram Fonte: Dados da Pesquisa.

É possível reconhecer a predominância da plataforma Moodle como Ambiente Virtual de Aprendizagem mais familiar aos entrevistados. Nota-se também, nas afirmações dos pesquisados, que algumas instituições optam por construir o próprio ambiente para a oferta de cursos a distância, como é o caso da "Plataforma Ânima" e o ambiente denominado "Portfólio", citados, respectivamente, pelo $\mathrm{G} 2$ e E3

Também é percebida, nas afirmações, a menção a situações em que foram utilizados serviços alternativos aos Ambientes Virtuais de Aprendizagem. No caso, utilizaram-se recursos digitais de armazenamento e sincronização de arquivos, disponibilizados pela empresa Google, como alternativa para auxílio ao ensino presencial em cursos de graduação. Essa constatação pode ser percebida nas dizeres do designer 2:

Agora me recordo que durante a graduação, tínhamos o uso do Google Groups. Tínhamos lá materiais, textos e referências, apostilas, mas para acesso comum da turma inteira. Em locais diferentes em épocas diferentes e nem todo mundo acessava simultâneo, mas a única experiência que eu tenho é o uso do Google Groups. Funcionava para o compartilhamento em algumas disciplinas para postagem de conteúdo para avaliação do professor. Se não, teríamos aquela questão de que "imprimir 
é demorado, é oneroso". E acabou sendo uma solução para a gente postar os trabalhos. (D2)

Embora os serviços do Google Groups não sejam essencialmente um Ambiente Virtual de Aprendizagem, podemos fazer aqui algumas ponderações. Diante da afirmação do D2, identificamos que o conceito de ambiente virtual pode, em algumas ocasiões, assumir o significado de um espaço essencialmente de compartilhamento e armazenamento de informações, deixando em segundo plano a possibilidade de interação. Supostamente, os educadores e educandos que faziam uso do recurso Google Groups privilegiavam somente o ambiente físico da sala de aula, o lugar majoritariamente da interação e da mediação.

Ainda considerando as afirmações do participante D2 e resgatando nossas ponderações no capítulo 2, reconhecemos o conceito de Ambiente Virtual de Aprendizagem não apenas como um local de armazenamento e compartilhamento de arquivos, mas essencialmente com um espaço onde se privilegie a interação entre sujeitos, objetos e conteúdos em situações de ensino-aprendizagem. Assumimos uma acepção para o AVA relacionada ao conceito de "espaço" proposto por Milton Santos (2006). O "espaço" sendo compreendido como "um conjunto indissociável de sistemas de objetos e sistemas de ações" (Santos, 2006, p.12). Ademais, considerando as formulações de Tori (2010), um AVA necessita essencialmente disponibilizar, dentre outros recursos, funcionalidades para a participação síncrona e assíncrona dos usuários, além de mecanismos para as avaliações e gerenciamento dos cursos.

Uma curiosidade também percebida na fase de identificação das experiências dos participantes está nos relatos do educador 3 e do designer 3. Ambos utilizaram Ambientes Virtuais de Aprendizagem, que originalmente se tratam de versões modificadas da plataforma Moodle pelas instituições de ensino e intituladas, respectivamente, "Portfólio" e "Portal do Aluno". Tais participantes verbalizaram esses nomes e aparentemente não reconheceram que se tratam de versões da plataforma Moodle.

Para concluir essa seção de caracterização dos participantes, foi perguntado também o grau de familiaridade em relação ao uso das Tecnologias da Informação e Comunicação para Educação a Distância. Por meio de uma escala de autoavaliação do tipo Likert, com grau de 1 a 5, perguntamos com qual número da escala 
se identificavam, sendo 1 para "pouca familiaridade" e 5 para "muita familiaridade" (Quadro 10).

\begin{tabular}{c|c}
\hline Participantes & $\begin{array}{c}\text { Grau de familiaridade em relação ao } \\
\text { uso das TDIC para a EaD }\end{array}$ \\
\hline G1 & 4 \\
G2 & 4 \\
G3 & 3 \\
\hline E1 & 2 \\
E2 & 3 \\
E3 & 5 \\
D1 & 5 \\
D2 & 3 \\
D3 & 3 \\
\hline
\end{tabular}

Quadro 10 - Grau de familiaridade em relação ao uso das TDIC para a EaD Fonte: Dados da pesquisa.

É interessante observar o relato do educador 1, que verbalizou a sua oscilação na familiaridade com o uso das TDIC ao longo dos anos, à medida que foram feitas escolhas no uso de determinados recursos em sua trajetória profissional e acadêmica.

Eu diria que hoje eu estaria, talvez, no nível 2. Eu já estive num nível, pensando assim, 4, talvez. Quando eu, depois de iniciar um aprendizado autodidata de computadores, num período ainda de 1993, que foi o meu primeiro computador, eu aprendi os programas de sistemas básicos do DOS de PC [...]. Ao longo do tempo, à medida que me tornei um usuário e comecei a fazer $\mathrm{o}$ uso sistemas específicos e fui abandonando outros [...]. Eu acredito que eu caí muito em relação a esse conhecimento que era mais ampliado. As coisas mudam muito rápido na área de informática. Então assim, hoje eu acho que estaria talvez no 2 ou talvez até 1 , num grau de 1 a 5. Bem abaixo. (E1)

Em geral, é bem variada a identificação dos participantes com a escala de familiaridade com o uso das TDIC. Os participantes se expressaram majoritariamente com um grau de incerteza, talvez receosos de se colocarem em um patamar extremo de "Muita" ou "Pouca" familiaridade. Eles se identificaram em uma posição intermediária, sinalizando, inclusive, a possibilidade e a necessidade de conhecer mais dos recursos atuais para a Educação a Distância. Em 
contraposição a essa constatação, dois participantes atribuíram valor 5, afirmando que possuem "Muita" familiaridade em relação ao uso das TDIC para a EaD

$\mathrm{Na}$ seção a seguir, optamos por classificar as respostas por grupos de respondentes. Acreditamos que a exposição agrupada das respostas é mais fácil de ser visualizada e compreendida. Desta forma, temos a apresentação e análise das impressões e concepções dos participantes (gestores, educadores e designers) de modo categorizado. Criamos subseções para explicitar de forma desdobrada, analisar detalhadamente as verbalizações dos respondentes e relacioná-las à presente pesquisa.

\subsubsection{1}

\section{A utilização dos AVAs pelo grupo de Gestores}

Perguntamos aos gestores se a simulação de uso durante aquela semana transcorreu da maneira como pretendiam. Os trechos das expressões dos participantes encontram-se a seguir:

Olha, eu encontrei dificuldades. Aquele EDX, eu achei ele bem mais difícil. Já o Edmodo, eu achei a plataforma mais tranquila. Ela tem um layout muito parecido com Facebook. E a inserção dos elementos lá eu achei bem mais tranquilo. Mais fácil. (G1)

Sim. Transcorreu. Eu tive um certo desconforto em criar um curso na plataforma do EDX. No Edmodo foi tranquilo. (G2)

[...] eu comecei pelo EDX [...] eu não sei se foi porque ao mesmo tempo que eu ia usando, eu ia descobrindo como é que usar a plataforma, eu estava construindo a aula. Então eu tava vendo o que a plataforma me permitiria, o que eu gostaria de colocar, pesquisando material. [...] Eu terminei a aula sem entender como configurar uma avaliação [...]. Eu consegui criar o título da avaliação, mas eu não consegui criar o conteúdo da avaliação. $\mathrm{O}$ texto, enfim... eu não consegui entender como criar a mecânica de interação desta avaliação. [...]. Eu achei interessante que ele tem uma descrição do lado direito de tudo que você pode fazer. Me deu alguma informação importante. Achei meio... um pouco confusa a coisa dos capítulos, dos livros-textos. Os capítulos ficaram no outro lugar. Eu gostaria que ele já tivesse junto aqui, que é uma coisa que Moodle me dá. [...] O Moodle, como já falei, eu já tinha uma experiência, então acho que isso me ajudou. [...]. Eu consegui fazer tudo que eu queria fazer, mas eu não sei se porque a minha cabeça já estava pensando como o Moodle pensa também. [...]. (G3) 
Podemos identificar nos dizeres dos gestores que o fato de o Moodle ser um ambiente conhecido pelos participantes facilitou a utilização. Outra constatação é que o fato de o Edmodo possuir uma interface similar à rede social Facebook também facilitou o uso. Já o EDX, por não possuir semelhança com o Moodle ou outro recurso digital conhecido, dificultou a operacionalização. Nas expressões dos participantes, podemos identificar a dificuldade em utilizar a plataforma EDX. Consideramos que o fato de esta pesquisa oferecer o primeiro contato aos participantes nessa plataforma, para a construção de cursos, pode ter provocado certo estranhamento durante a utilização. $\mathrm{O}$ desconforto durante o uso é revelado pelos três gestores.

Nessa direção, foi perguntado aos pesquisados quais foram as dificuldades encontradas durante a utilização dos ambientes.

Olha, a dificuldade é para conseguir compreender o que fazer em cada aba daquela (no EDX). Talvez por não ter feito nenhuma otimização no espaço, eu não tenha esse conhecimento. (G1)

No EDX fugiu um pouco a navegação popular. Eu tive um certo desconforto em criar um curso na plataforma do EDX. (G2)

[...] eu não consegui colocar os textos visíveis na aula (no EDX). $\mathrm{Eu}$ indiquei para o aluno entrar no livro para ler. Deu um problema também na proposta de discussão. A única ferramenta que consegui encontrar, que tinha mais a ver com um fórum, porque eu ia fazer uma interação online entre alunos, era a ferramenta de discussão e ela não funcionou. Não sei se uma questão técnica, mas eu não consegui carregar a discussão em nenhum momento. Eu consegui inserir na aula, mas não consegui visualizar como funciona. Então, o EDX foi uma experiência mais truncada, mais difícil. [...] (G3)

Notadamente, os participantes gestores indicaram as características da plataforma EDX que dificultaram as simulações de uso do ambiente. Indicaram dificuldades em percorrer e navegar pelos recursos, além da dificuldade de identificar funcionalidades no ambiente EDX.

A gestora 1 sinalizou a eventual necessidade da customização do ambiente EDX como possibilidade de facilitar a identificação e o entendimento do funcionamento do ambiente. O gestor 2 citou a característica de o EDX não ser concebido com uma interface similar aos demais recursos digitais contemporâneos e "populares". A gestora 3 explicitou seu esforço em realizar uma proposta de aula 
com atividade em um fórum, enfatizando a importância da interação no ambiente virtual. Neste caso, identificamos na proposta da gestora 3 a intenção de priorizar uma prática alinhada à abordagem Vygotskyana de ensino-aprendizagem.

Segundo Vygotsky (1984), o sujeito se produz na e pela linguagem. Para esse autor, é na dialética das interações do sujeito com o outro e com o meio que as formas de pensar são construídas, neste caso, sendo indispensável promover situações que estimulem a interação em Ambientes Virtuais de Aprendizagem.

Quando questionados sobre as facilidades encontradas durante a utilização dos ambientes, a gestora 1 afirmou que achou muito mais fácil utilizar a plataforma Edmodo. Ela conseguiu "inserir os elementos na biblioteca, colocar os artigos, colocar os slides, tarefas, [...] bem mais fácil de usar” (G1). Já o gestor 2 valorizou também elementos positivos no Edmodo: “o menu e a navegação bem familiar com outras ferramentas que são populares na internet. Então os menus estavam onde [ele] já esperava que estivessem" (G2). Finalmente, a gestora 3 também explicitou que teve facilidades durante o uso dos ambientes Moodle e Edmodo, conforme segue:

\begin{abstract}
No Moodle eu achei fácil fazer a configuração geral separar as semanas, colocar os materiais, designar as tarefas. [...]. No EDX adicionar os conteúdos foi fácil, adicionar as avaliações é que eu acho que foi mais difícil, não consegui configurar. Agora no Edmodo eu achei que foi tudo bem fácil também. A única coisa que me chamou minha atenção na Edmodo foi o fato dele ser estruturado como uma rede social. E aí na hora que eu fui colocar os conteúdos ele não oferece a opção de fazer uma aula 'estruturadinha" de um curso. [...]. (G3)
\end{abstract}

Percebe-se que o fato de o Edmodo apresentar características semelhantes à rede social Facebook foi determinante para as facilidades de uso pelos voluntários nesta pesquisa. Certamente, os entrevistados já utilizaram essa rede social e assim indicaram as similaridades com o Edmodo, o que na visão deles tornou fácil a construção da aula.

Após essas constatações, perguntamos aos participantes como foram a identificação e a localização das funcionalidades nos ambientes utilizados. Eles explicitaram que no Edmodo e no Moodle a identificação dos recursos é algo simples de se detectar: 
[...] na hora que você insere uma pergunta (no EDX) e aí depois, você tem que mexer muito... Eu achei mais difícil inserir textos... e tudo. Na hora que eu percebi que eu tinha lançado errado, aí eu já tinha lançado. Então eu tive que ir lá, voltar, tirar, corrigir, achei ele mais complicado. O Moodle é tranquilo porque como eu já trabalhei com ele há um tempo atrás [...]. Agora no Edmodo eu consegui inserir tudo: links, enquetes, atividades, textos na biblioteca [...]. (G1)

[...] o menu dele (Edmodo) eu acho que está mais exposto e as ferramentas dele estão mais visíveis na tela, na hora em que você entra como administrador. No EDX, os ícones dele são um pouco diferentes, não são tão comuns quanto os do Edmodo e do Moodle. E no Moodle como eu já conhecia a ferramenta de navegação dele, para mim foi muito rotineiro. (G2)

Achei bem tranquilo (no Moodle), mas, por exemplo, eu sei que eu tenho que apertar o botão escrito "ativar edição" no Moodle para poder editar. Eu sei que é uma coisa que tenho que fazer, mas quando é alguém que não conhece o Moodle, se enrola. No início eu me enrolava. Você não espera que você tem que apertar um botão para começar a editar uma coisa que você já entrou para editar. (G3)

$\mathrm{Na}$ avaliação da identificação e da localização das funcionalidades nos ambientes, percebemos que a gestora 1 destacou que são necessários vários procedimentos, caso o usuário realize alguma ação equivocada no ambiente.

Diante disso, reconhecemos que o fato de os pesquisados já terem utilizado o Moodle e a rede social Facebook, sendo esta última similar ao Edmodo, propicia certa facilidade em localizar as funcionalidades e recursos nos ambientes. Temos, assim, uma premissa que indica a necessidade de um aprendizado do uso dos ambientes quando estes não possuem características similares a outros recursos conhecidos por educandos e educadores.

Perguntamos também aos participantes como se deu o planejamento da aula e das atividades nos Ambientes Virtuais de Aprendizagem. Os trechos das expressões dos gestores participantes estão apresentados a seguir:

Eu tentei colocar assim: considerando o tempo em que o aluno conseguisse justamente responder a algumas perguntas. Tem um material didático para ajudar com alguns jogos... Então ele conseguiria construir o conteúdo dele a partir deste contato. Eu fiquei muito presa nessa escolha do material bibliográfico. E aí eu não sei se seria o melhor. Colocar o material que subsidiasse, para ele pudesse responder as perguntas. (G1) 
Bom, eu peguei duas imagens e considerei que ia montar a aula com essas duas imagens e colocar um texto de introdução da aula e a descrição. Então, fiz nesses três modelos. Eu fiz a mesma a mesma coisa nas três plataformas. E o planejamento em si foi basicamente fazer o upload de uma imagem com o nome e descrição do curso. E eu não inseri nem uma atividade específica não. Só fiz essa parte criação básica do curso. (G2)

Assim, não deu tempo de produzir material. Na verdade, eu fui coletando da internet, pegando alguns vídeos, pegando um grande PDF que quebrei em capítulos. Então, eu pensei como num primeiro momento de introdução "à teoria das cores". Num segundo momento de pensar um desdobramento desta teoria, de pensar em paletas de cores. Num terceiro momento de começar a pensar uma aplicação. E um quarto momento de finalizar essa aplicação. Na verdade, o $3^{\circ}$ e $4^{\circ}$ momentos seria coisa só. É o desenvolvimento um projeto, de um cartaz. [...]. Aí esse esboço de projeto, os alunos e colegas comentariam e no final...na verdade a última, quarta unidade, seria só a entrega do projeto. (G3)

A gestora 1 mencionou diretamente, no trecho que recortamos, a figura do educando que supostamente utilizaria o ambiente, participaria da proposta de aula e realizaria a atividade. Nos demais enunciados também reconhecemos a preocupação com a figura do educando na construção da aula, no entanto se revela subjacente na elaboração das aulas.

Pudemos reconhecer, nas falas dos entrevistados, as possibilidades de inserção de diferentes recursos e materiais nos três ambientes disponibilizados. Os três gestores participantes conseguiram construir as aulas em cada um dos ambientes, mesmo tendo encontrado dificuldades nas plataformas com as quais tiveram o primeiro contato, no caso o EDX. Notamos que os três gestores sinalizaram as potencialidades do Edmodo como um dos ambientes mais fáceis de se utilizar. Os gestores 1 e 2 destacaram a facilidade de localização dos ícones, menus e funcionalidades no Edmodo, sendo uma plataforma fácil de gerenciar.

A gestora 3 sinalizou que o formato de rede social, para um Ambiente Virtual de Aprendizagem, não favorece a apresentação da totalidade das etapas ou fases de um curso. Dificulta a visualização daquilo que vai ser ofertado durante um curso. Por outro lado, ela reconhece que se trata de uma estrutura que favorece muito a interação. "Eu acho que tudo que está ali é quase que como um post de Facebook, que está suscetível de comentários. [...] Quando você coloca no esquema de rede social eu acho que favorece a interação". (G3). 
Entretanto, a gestora 3 também apontou a suposta dificuldade dos educadores em acompanhar o volume de posts de diferentes educandos no Edmodo. Ela lembrou que no Moodle isso seria mais fácil de gerenciar, uma vez que se tem um espaço próprio para discussão que o caso do fórum. "Então ali, naquele fórum, cada um só vai acrescentar um tópico e os outros vão comentar os trópicos dos outros. Só vai estar ali. Então eu acho que tem uma tensão aí, entre interação e controle que é inevitável". (G3).

$\mathrm{Na}$ subseção a seguir, apresentaremos a discussão dos enunciados verbalizados pelos participantes educadores acerca da utilização dos ambientes.

\subsubsection{2}

\section{A utilização dos AVAs pelo grupo de educadores}

Sobre o processo de utilização dos AVAs, perguntamos aos educadores como havia transcorrido tal uso. Indagamos se a utilização dos AVAs transcorreu da maneira como pretendiam. Os trechos das expressões dos pesquisados estão apresentados a seguir:

De forma alguma. Tive muitas surpresas. (E1)

Não. Especialmente o EDX. Não transcorreu da maneira como eu pretendia. Eu achei o EDX confuso, mais difícil de fazer... de você poder manipular o ambiente. Eu achei bem mais tranquilo o Moodle pela familiaridade que já tenho. E também gostei bastante do Edmodo. No caso do EDX, eu achei ele pouco amigável. (E2)

Do Moodle sim. Dos outros dois eu tive dificuldade. Um deles eu tive muita dificuldade pela questão do idioma. Tem um que tem mais mensagens em inglês. Eu acredito que é EDX que aparece mais mensagens em inglês, este eu tive mais dificuldade. Foi o segundo que eu entrei. O terceiro, o Edmodo, eu já consegui fazer mais coisas. (E3)

Os participantes educadores, assim como os gestores, também sinalizaram dificuldades na utilização da plataforma EDX. O educador 1, talvez pelo fato de nunca ter tido contato nem com os ambientes nem com redes sociais, manifestou que teve muitas surpresas durante a utilização das plataformas. 
Também questionamos os educadores sobre as dificuldades encontradas durante a utilização dos três ambientes. Optamos por explicitar um recorte dos enunciados do educador E1, que não conhecia tais ambientes:

\begin{abstract}
Vou começar pelas dificuldades. Como eu não conhecia. Agora já tenho um entendimento. Eu fui buscando a construção daquilo que foi me dado na orientação de uma aula. E como o primeiro que eu peguei foi o EDX, eu não encontrei assim esta opção de aula. Na verdade, quando eu lido com computadores eu tenho uma tendência a operar de forma mais ortodoxa, digamos assim. Então se tem um termo, eu vou diretamente nele. Como eu não encontrei (o termo) "aula", só encontrei "curso". Eu pensei: - será que eu tô fazendo alguma coisa errada? Aí eu procurei, procurei, não encontrei. Aí eu descobri que tinham "sessões". Mas o que é uma "sessão" se eu quero criar uma "aula"? Aí eu não entendi. [...] Aí descobri que tinha um item, digamos na hierarquia, mais profundo, que era o de "página". Eu falei: deve ser aqui. Esse foi um momento de uma certa dificuldade. Mas essa dificuldade inicial se transformou em vantagem quando eu percebi que nas outras plataformas cada uma delas utiliza um conceito diferente. [...]. Então essa foi uma... Não digo dificuldade só. Mas uma limitação que depois de ter passado por tudo mais se provou ser algo que era justamente de compreensão do tipo de instrumento, que é a plataforma. [...]. Se hoje eu entrar por exemplo, num outro programa de editoração, para além daqueles que já trabalho, eu já vou com essas expectativas e já sei mais ou menos o que vou procurar. Lá eu não sabia para onde ir. Então esta é a dificuldade. Talvez a dificuldade maior dificuldade é: - para onde ir para conseguir produzir conteúdo que vai ser acessado por usuários que são estudantes. (E1)
\end{abstract}

Reconhecemos nas verbalizações iniciais do E1 a necessidade de os ambientes apresentarem características padronizadas e rígidas, no que se refere aos termos adotados e percursos permitidos aos usuários. Posteriormente, ao iniciar seu contato com os ambientes, ele nos revela que constatou o ambiente como algo que se apresenta de modo variável no âmbito das nomenclaturas das funcionalidades e da presença de características distintas quanto à flexibilidade de utilização. No caso do EDX é adotado o termo "sessões" como parte integrante de um curso. Notadamente, no padrão tradicional de educação, encontramos sua equivalência na denominação "aula".

Ademais, o educador E1 nos afirma que o uso de determinado recurso ou instrumento tende a gerar um certo aprendizado de uso. Assim, do ponto de vista da interface, e na visão desse participante, isso acende certas expectativas para esse mesmo usuário, quando necessita utilizar outro recurso da mesma classe. O usuário 
tende a fazer um percurso similar ou a procurar as mesmas funcionalidades em recursos diferentes.

Após indicarem as dificuldades encontradas durante o uso, passamos a perguntar aos gestores quais foram as facilidades encontradas. Algumas das expressões dos pesquisados estão descritas, conforme segue:

Pois é. As facilidades eu posso te dizer que eu tive poucas na primeira entrada. Eu não me lembro na verdade de facilidade. Eu fiquei confuso. Entrei no primeiro e não encontrei o que eu procurava. Fui para a segunda plataforma, também não encontrei e achei diferente. Fui para a terceira e na terceira eu não consegui nem acessar. Nem consegui registrar o usuário. Aí comecei a ficar mais confuso ainda. Inicialmente eu só tive no meu ponto de vista dificuldades [...]. A minha esposa fala que eu procuro com as mãos. Então se eu procuro num lugar eu não olho para outro lugar. Se não estar naquele lugar, eu demoro para poder fazer o caminho para procurar em outros lugares. É uma característica que não vem do Design, vem da filosofia. Isso é uma característica própria filosofia. Eu sou um sujeito que ainda pensa ao modo da filosofia, ou seja, introvertido. Eu não olho muito para a área externa. Eu tenho que fazer um esforço enorme para ver o entorno. [...]. (E1)

No caso do Moodle e do Edmodo eu achei e eles bem tranquilos, assim. No caso do Moodle é mais difícil avaliar pela familiaridade que eu já tenho com o ambiente. No caso do Edmodo, ele é bem similar aos outros ambientes que nós temos. Então, isso facilita a utilização, coisa que você não consegue encontrar no caso do EDX. As ferramentas no EDX estão escondidas... Então é bem mais difícil de você conseguir customizar para usar como um ambiente de aprendizagem. (E2)

De anexar um arquivo. De criar o curso. É fácil nos dois. Em dois deles né, foi fácil. Só no terceiro eu tive dificuldade. (E3)

Identificamos nos enunciados dos educadores que o contato com recursos conhecidos ou similares tende a facilitar a utilização. Utilizar um ambiente virtual de aprendizagem familiar torna a tarefa de construir uma aula menos árdua. Em situações de ensino-aprendizagem, o uso de recursos e ambientes já experimentados poderá favorecer a adesão de educadores e educandos. Caso contrário, demandará a realização de ações específicas para apresentar e ensinar como usar o ambiente.

Também perguntamos aos participantes como foram a identificação e a localização das funcionalidades nos ambientes utilizados. 
Não é nada que seja que seja complicado. Está lá, sabe? Eles têm uma mudança que difere de alguns programas que já tem existência, mas nada que... Isso é uma limitação que não é talvez do programa, seja minha. Identifico muito mais como minha. Quer dizer: alguém que já vai tentando buscar esse caminho, porque normalmente os programas funcionam assim. [...]. É uma questão de adaptar. A partir do momento em que eu descobri que está ali eu passo ali também e obvio né [...]. (E1)

No caso do Moodle foi bem tranquilo, porque as funcionalidades você consegue visualizar com bastante tranquilidade. O Edmodo facilita pela sua semelhança com outras plataformas com outros ambientes, com outras interfaces. No caso do EDX não. Eu tive bastante dificuldade em encontrar algumas ferramentas, alguns botões, algumas funcionalidades, elas não estão claras. Elas não estão... A interface não é amigável o que dificulta bastante você utilizar o ambiente. (E2)

Olha, em dois deles foi tranquilo. Não tive muita dificuldade não. O terceiro, realmente eu não consegui fazer nada nele. O EDX. (E3)

Os relatos dos educadores E1 e E2, que sinalizam a facilidade de identificar e localizar as funcionalidades nos ambientes Moodle e Edmodo, reforçam a ideia de que o Moodle, por ser um ambiente que já utilizaram, e o Edmodo possuir semelhanças com a rede social Facebook, os colocam em vantagem se comparado ao EDX.

Após verificarmos as dificuldades e facilidades encontradas pelos participantes e como foi a identificação das funcionalidades nos ambientes, passamos a perguntar como foi o planejamento da aula e das atividades nos Ambientes Virtuais de Aprendizagem.

Pois é, na verdade não planejei. O que eu fiz foi buscar a internet uma aula específica sobre o tema que considerasse que tinha, digamos, tópicos que cercavam mais ou menos o tema, dentro da forma como imagino que seria interessante apresentar. Então busquei em três ou quatro lugares diferentes. Na hora que eu encontrei aquilo que estava em uma distribuição boa. Com um número, digamos assim, de tópicos que ao mesmo tempo trazia conhecimentos sobre uma determinada informação, mas não eram extensos demais nem curto demais e que aqueles que tratavam do tema apresentando elementos que precisavam ser corroboradas ou reforçados por imagens continham isso, falei: esse aqui está mais ou menos adequado. Então eu transferir este conteúdo fazendo mais ou menos sem muito trabalho a mesma divisão que já constava na minha escolha original daquela aula. (E1) 
Eu utilizei alguns arquivos de PDF, textos...Tentei disponibilizar textos e tentei utilizar de algumas tarefas, atividades e fóruns, né? Tentei criar algumas mensagens de forma a interagir com os alunos. Então, basicamente foi isso que eu tentei fazer. Vídeos... (E2)

Olha, na verdade como era um tema que eu desconhecia. Você falou que poderia consultar internet, eu peguei alguma coisa na internet e tentei aplicar aquilo ali dentro do programa. Dessa maneira. Mas quando eu tô trabalhando realmente num curso em que eu sou professor ou estou como tutor, aí eu preparo como se fosse uma aula presencial mesmo. (E3)

Notamos nos dizeres dos educadores que no planejamento da aula buscaram alimentar o ambiente virtual com uma diversidade de materiais sobre o tema proposto. Buscaram explorar os recursos dos ambientes de modo equilibrado e dando ênfase às possiblidades de interação e mediação nos processos de ensinoaprendizagem.

Solicitamos aos educadores descrever um pouco mais a experiência de utilizar os três Ambientes Virtuais de Aprendizagem. As verbalizações estão expressas a seguir:

[...] a experiência inicial foi algo angustiante porque eu me senti como na primeira vez que eu peguei um computador em 1993. Quando eu comprei um computador. Eu não sabia para onde ir [...]. Me deu uma certa angústia, num certo sentido [...]. Passada essa sensação inicial, quando eu entrei mesmo no âmbito da compreensão do que que era aquelas plataformas eu me senti muito atraído [...]. Aí sim, eu fui me interessando cada vez mais. $\mathrm{E}$ tenho interesse em aprender mais. Isso me despertou para um universo que eu não imaginava que poderia me despertar. (E1)

O Edmodo eu gostei bastante, porque eu acho que o Edmodo é uma ferramenta que pode servir, principalmente como suporte a aprendizagem. Não como um ambiente principal, mas como um ambiente complementar. Pela linguagem dele que é uma linguagem fácil. Uma linguagem interativa. Então eu acho que ele pode ser um canal de apoio à aprendizagem. Até como um suporte ao ambiente, ao AVA. O Moodle pelo fato dele ter uma grande capilaridade no mercado e ele já está bastante divulgado como ambiente. A utilização foi bastante tranquila pela familiaridade que já tenho com o recurso. Então foi o mais fácil de disponibilizar conteúdo. O EDX eu já não gostei. Eu achei ele pouco amigável, tive dificuldades. Portanto eu não consegui trabalhar o conteúdo da forma como eu gostaria. (E2)

Olha, o Moodle, como te falei, o Moodle para mim ele é muito tranquilo. Eu poderia até ter ficado com ele bastante tempo e mexido muito porque eu conheço ambiente a bastante tempo. $\mathrm{O}$ 
EDX para mim foi angustiante. Infelizmente ainda não tem esse domínio do Inglês, então eu teria que ficar olhando, buscando no dicionário para entender o que tá escrito ali, então não fiz nada. Foi horrível. É um analfabeto digital mesmo. O outro conseguir também fazer alguma coisa. Foi razoável. (E3)

Pudemos identificar que os educadores participantes destacaram o EDX como o mais difícil de se utilizar, por ser um ambiente que possui caraterísticas de interface distintas aos recursos comumente utilizados.

Além disso, pudemos também identificar, na concepção do educador E2, que, embora o Edmodo apresente uma interface propícia à interação, trata-se de um recurso capaz de servir como um apoio à aprendizagem e não como um ambiente principal. Diante disso, percebemos que o significado atribuído ao conceito de Ambiente Virtual de Aprendizagem, na visão do educador E2, perpassa pela presença de certas características típicas de um Ambiente Virtual de Aprendizagem convencional. Nesse caso, supostamente pelo fato de o Edmodo, ser na essência uma rede social educativa, foi caracterizada como um espaço completar ao Ambiente Virtual de Aprendizagem.

$\mathrm{Na}$ subseção a seguir, apresentaremos a discussão dos enunciados verbalizados pelos participantes designers acerca da utilização dos ambientes.

\subsubsection{3}

\section{A utilização dos AVAs pelo grupo de designers}

Perguntamos aos designers como transcorreu a utilização dos Ambientes Virtuais de Aprendizagem. Questionamos se, durante o período de uma semana, o uso transcorreu da maneira como pretendiam. Observamos que os três participantes designers encontraram dificuldades, tiveram imprevistos e encontraram situações inesperadas ao utilizarem os ambientes. As verbalizações dos três participantes designers demonstram essas situações.

[...] eu achei que deveria ser mais fácil e acabou que não transcorreu como eu imaginava. Eu tive uma certa... chegou uma hora que eu "empaquei", vamos dizer assim. Eu imagino que todo programa tem um nível de uma curva de aprendizagem, isso aí é normal, você até aprender a fazer as coisas. Mas ali estava... tinha um certo... eu não queria me alongar muito, então eu falei: - já vou pular para outro para ir experimentando e vou comparando, de repente até me dará a ideia de como voltar no Moodle. E foi o que acabou acontecendo. Aí eu fui para o EDX 
e o EDX fluiu. E eu consegui terminar a aula com muito mais facilidade. Intuitivamente eu achei a aprendizagem dele muito mais rápido. Aí eu pulei de volta para o Edmodo e também consegui ir para o Moodle e depois eu conseguir me desvencilhar do problema que eu estava no Moodle. E fui em frente e aí consegui configurar as aulas. Se eu fosse colocar na ordem, a minha facilidade de entender o programa foi essa: o EDX primeiro, depois o Edmodo e o Moodle por último [...] (D1)

Não. Não transcorreu, porque eu tive dificuldade de localizar as ferramentas as interfaces dos três objetos. Só um deles foi bemsucedido na experiência de postar conteúdo de organizar de forma geral [...]. (D2)

Eu achei que seria um pouco mais simples. Como foi a primeira vez em cada uma das plataformas, eu achei que o meu primeiro contato foi um pouco difícil. Bem semelhante à quando eu iniciei o meu curso online. Se eu passasse a mexer várias vezes, lesse cada vez mais...com a prática talvez ficasse mais fácil. Em princípio, em cada um dele eu tive um pouco de dificuldade. (D3)

Identificamos nos relatos dos designers que o fato de eles não terem utilizado os ambientes anteriormente à pesquisa nos trouxe informações interessantes. $\mathrm{O}$ designer D1 achou mais fácil utilizar o EDX, em contraste com as opiniões dos gestores e educadores nas subseções anteriores. O percurso utilizado pelo designer D1 nos faz perceber que o fato de não utilizar determinada classe de recursos digitais não acende certas expectativas para esse mesmo usuário. Conforme já sinalizado pelo educador E1, na subseção anterior, o usuário não irá fazer um percurso similar ou procurar as mesmas funcionalidades em recursos diferentes de mesma classe.

Percebemos, por meio dos enunciados, que os designers imaginavam ser mais fácil utilizar os ambientes. A partir desse primeiro contato, verbalizaram uma nova concepção no qual o ambiente é atualmente caracterizado como algo que precisam aprender a utilizar. Notamos isso nos seguintes trechos: "imagino que todo programa tem um nível de uma curva de aprendizagem" e "se eu passasse a mexer várias vezes, lesse cada vez mais...com a prática talvez ficasse mais fácil”.

A partir disso, questionamos também quais foram as dificuldades encontradas durante a utilização. Identificamos que algumas das dificuldades encontradas estão relacionadas ao entendimento das funcionalidades para a preparação das atividades. Notamos no relato do designer (D1) a dificuldade em elaborar questões nos ambientes: 
[...]. Eu achei que o EDX ele tem um botão do lado direito para visualizar que é muito óbvio. Porque todo mundo que está montando alguma coisa, você quer ver como aquilo vai se apresentar para o aluno, né? [...]. Outra coisa, por exemplo, às vezes quando eu queria colocar uma imagem para acompanhar os textos, assim das aulas, ela entrava às vezes ou muito grande ou distorcida. Eu achei curioso isso! Eles colocam em parâmetro o "default", digamos... né? O que é dado é uma situação que você tem que dar parâmetros. [...]. Se a gente que é designer, eu confesso, eu tive dificuldade: às vezes a imagem estava fora de tamanho, às vezes eu achei que ficava feia, não tava entendendo como centralizar ali. Eu imagino certos colegas que não tem familiaridade com largura, dimensão de imagem, e tudo. Como é que deve ficar para eles? (D1)

Nesse relato do designer D1, ficam evidentes a busca pela construção e a utilização de elementos que propiciem uma aproximação e identificação com o outro, neste caso o educando. Também notamos a valorização do uso da imagem nos processos comunicacionais, dando ênfase a um sujeito em sua capacidade de realizar "leituras" e de dialogar com o mundo por meio de imagens.

Podemos observar no relato do participante D1 um certo senso altruístico, numa relação educador-educando. Notamos uma concepção de docência alinhada à uma vertente de aproximação e de interação com o outro. Observa-se uma perspectiva de compreensão da natureza dialógica própria do mundo da vida, defendida por Bakhtin (2003).

O modo como eu vivencio o $\boldsymbol{e u}$ do outro difere inteiramente do modo como vivencio o meu próprio $\boldsymbol{e u}$; isso entra na categoria do outro como elemento integrante, e essa diferença tem importância fundamental tanto para a estética quanto para a ética. (BAKHTIN, 2003, p.35; grifos do autor).

Após identificar as dificuldades no uso dos ambientes pelos designers, perguntamos quais as facilidades encontradas durante a utilização.

Essa daí eu achei, vamos dizer assim, pode colocar a edição no EDX [...]. Então, no EDX eu criei um post, eu poderia ter explorado mais, mas acabei falando assim: - acho que isso aqui fica bem claro, porque eu achei o EDX também uma facilidade, porque ele me pareceu o mais fechadinho. O sujeito não sai. Você clica no vídeo e ele não sai, ele vai na ordem. [...]. O Moodle no modo tarefa em que eu possa receber o arquivo, eu achei isso muito prático. Imagina que você não ter aquela coisa que a gente tem: - "Oh! todo mundo tem que mandar para o e-mail". Aí o aluno manda o arquivo e aí fica: - "E aí? Recebeu?" - "Recebi!". Aquelas coisas...aquelas trocas. [...] O Edmodo também tem o 
modo tarefa, mas eu não entendi como colocar para receber o arquivo. Eu acho que gravar vídeo é muito prático para explicar principalmente essa parte de cor, por exemplo. [...] (D1)

Teve a facilidade de aceitação dos diferentes formatos que testei. Tanto para imagem no caso JPEG e PNG. Os links... no caso da terceira em específico, do Edmodo, né. Nas outras duas eu não conseguir avançar, como já disse. Mas no caso dela eu achei bem versátil, do tipo de conteúdo que ela aceita, da própria diagramação depois de ter tudo postado lembra muito uma rede social. Então eu considerei válido sim. Só no caso da Edmodo. Das outras duas não enxerguei facilidade não, nem benefício. (D2)

Eu acho que a última plataforma, a Edmodo, eu achei ela visualmente mais interessante. $\mathrm{E}$ eu achei mais fácil achar algumas informações nela. (D3)

A partir dos enunciados dos entrevistados, constatamos que o designer D1 nos revela uma concepção em que o Ambiente Virtual de Aprendizagem necessita apresentar características de espaço coordenado e demarcado de interações. O entrevistado revela a necessidade de orientar, conduzir e focalizar as possíveis ações dos educandos de modo que eles não se dispersem na internet e se afastem dos objetivos propostos das aulas e atividades. Os recortes dos trechos com as expressões "fechadinho", "você clica no vídeo e ele não sai" e "ele vai na ordem" demonstram essa constatação.

Além disso, notamos que os três usuários identificaram que o Edmodo é um ambiente fácil de utilizar, com destaque para os comentários do D1, que ressaltou as potencialidades do EDX. Também percebemos que os três designers reconhecem as facilidades implícitas na interface do ambiente Edmodo.

Após essas constatações, perguntamos sobre a identificação e a localização das funcionalidades nos três ambientes utilizados. As percepções dos três designers acerca dos ambientes estão apresentadas, conforme segue:

[...] acho que quanto mais simples melhor, pois o professor já tá fazendo tanta coisa, pensando tanta coisa. Então às vezes que o excesso de possibilidades já dados assim, de primeira, eu acho mais complicado. O Edmodo que eu senti foi que, a única coisa que me incomodou nele, é que... [...] Ele talvez não permita o controle muito grande, parecendo um Facebook, pareceu uma rede social. Você vai postando as coisas vão ficando ali. Então eu já comecei a ter preocupação assim: - será que o aluno que entrar vai conseguir ver os posts? Porque às vezes tem um post lá na frente que estou dando discussão de uma pergunta que seria 
interessante ele quebrar a cabeça sem ter visto aquela discussão. Enquanto que os outros têm uma coisa mais linear... vê essa tela, depois vê essa. E ali parece que fica um monte de post. Por outro lado, eu imagino que os alunos podem comentar e começar a surgir uma discussão ali mesmo. Se for esse o caso, é uma coisa interessante também, dependendo da aula, né. (D1)

Olha, a parte dos ícones, as funções eu identifiquei através disso. No caso do Edmodo que foi onde eu consegui avançar, foi bem intuitiva com a crítica única que o ícone de anexo, que para mim não é muito familiarizado. Em vez de um clip igual seria no email ou outras interfaces que eu utilizo, ele utiliza uns ícones aqui de página que não identifiquei de início que seria para anexar. Mas passando o cursor por cima do ícone, ele também explica para que ele serve. Então na dúvida de fazer a leitura das ferramentas ou para que serve o ícone, você passa o cursor por cima dele, ele lhe mostra. Ele lhe dá uma dica por escrito. No caso aparece anexar, ícone, links, e isso se torna mais fácil. (D2)

O layout da plataforma Edmodo estava mais similar às outras coisas que eu já uso. Tinha ícones mais semelhantes, tinha símbolos mais próximos das coisas que eu já conheço no dia a dia, que é muito parecido com o que tem no curso que eu já faço. Os outros estavam um pouquinho mais esquemáticos e um pouquinho mais difíceis. Não consegui visualizar muito fácil. (D3)

Percebemos, a partir dos relatos dos designers participantes, a necessidade de se equilibrar a quantidade de funcionalidades nos ambientes, para não confundir ou dificultar o uso do ambiente pelos iniciantes. Notamos também, nas expressões do designer D1, que no Edmodo, pela sua similaridade à rede social Facebook, existe um limitador que está relacionado à sobreposição de posts que se dispersam ao longo da Linha do Tempo "Timeline".

Nos dizeres no designer D1, também conseguimos constatar uma preocupação de como serão os usos do ambiente tanto pelo educador quanto pelo educando. Para D1, os educadores necessitam de um ambiente simples, pois, na sua visão, esses profissionais estão rotineiramente envolvidos com muitas demandas no âmbito do ensino. Já outro ponto interessante destacado pelo designer D1 se refere ao uso do ambiente Edmodo por educandos. Na perspectiva desse designer, é interessante reconhecer o potencial de interação do Edmodo, pois a cada post "podem comentar e começar a surgir uma discussão". Mas ele também salienta o risco de dispersão e a dificuldade de acompanhar as inúmeras postagens naquele ambiente. 
Após isso, perguntarmos aos designers como planejaram a aula e as atividades nos Ambientes Virtuais de Aprendizagem. Os enunciados estão apresentados, conforme segue:

[...] eu tive uma certa dificuldade que foi assim: uma coisa que eu imaginaria que fosse funcionar... sabe quando você mostra uma imagem e pergunta assim: - vocês acham que esse vermelho evoca paixão? - ou $\mathrm{O}$ vermelho traz agressividade ao quadro? -São perguntas que às vezes gente faz e que não tem resposta certa. É para tentar ter uma conversa com os alunos. Isso realmente eu não soube como criar. Eu acho que é mais fácil você colocar: - o vermelho é o quê? $\mathrm{A}, \mathrm{B}, \mathrm{C}$ ou $\mathrm{D}$. Mas só que isso não era o que queria, naquele momento. Mas depois que você já colocou alguns conceitos em jogo, você pode até fazer uma pergunta o que é o certo e o errado dentro daquele conceito. No início para você tem uma discussão, para introduzir o tema eu não soube fazer, confesso [...]. Bom, vamos supor que eu quisesse que os alunos respondessem: - quando você olha para este quadro você pensa o quê? Cada um falaria o que quiser e eu vou colher aquelas respostas para daqui uma semana a gente conversar sobre aquilo, sei lá. [...]. Mas ele sempre pedia uma resposta certa. [...] (D1)

Como se trata de um teste, separei uma introdução do tema que foi proposto, que seria "Teoria da Cor". Anexei um texto de início, seguido de duas imagens em formatos diferentes: Jpeg e Png, um link de vídeo do YouTube, em formato de html. É... somente o link mesmo. Eu copiei o link e colei no campo. E testando depois da realização que ele apareceu aqui ok, pelo menos. Não sei se é o caso de testar com outro acesso em outra máquina para ver se seria a mesma resposta. Mas eu utilizei vídeo em formato de link, duas imagens e um texto por escrito. (D2)

Eu pensei em usar recursos de imagem, de vídeo e fiz uma breve pesquisa sobre o tema. Pensei em anexar nesta aula, seria sugerido um texto, um vídeo e alguma imagem explicativa. Algo mais dinâmico para facilitar, acrescentar e complementar o texto. (D3)

No caso dos relatos dos três designers, percebemos a valorização e a busca por levar em conta a natureza polissêmica da imagem, apoiada na perspectiva dialógica da visão bakhtiniana. Vislumbrou-se o uso da imagem para evidenciar e elucidar as possibilidades de leitura de imagens. Neste caso, temos as imagens sendo consideradas à luz de Bakhtin (2006), como formas enunciativas que compõem concretamente a vida dos sujeitos, os interrogam e evocam suas respostas.

Notamos, nos comentários do designer (D1), a necessidade de o ambiente dispor de uma flexibilidade para situações nas quais o educador elabora perguntas 
em que não há respostas certas. Seriam situações em que as perguntas servem para estimular a reflexão e o debate acerca de determinado tema.

Após esses comentários acerca das funcionalidades e do planejamento da aula, disponibilizamos aos designers a abertura para tecerem comentários acerca da experiência de utilizar os três Ambientes Virtuais de Aprendizagem. Diante disso, reconhecemos os comentários dos designers (D2 e D3), que sinalizam as dificuldades e as limitações em utilizar os ambientes. As verbalizações indicam as facilidades de uso apenas no ambiente Edmodo.

No geral, eu não considero muito satisfatório, porque como eu disse só fui bem-sucedido em uma delas. Então a ferramenta em si, se esses três são a amostra geral do que seria este tipo de proposta, de conteúdo de organização, eu não considero algo intuitivo não. Algo fácil não, pelo menos para mim. Com exceção desse Edmodo, mas talvez seja por se tratar de um primeiro acesso. Talvez precisasse de alguma prática ou alguma orientação ou pré-orientação antes de usar para ser algo mais bem-sucedido nesse sentido. Agora das três eu só recomendo a Edmodo, realmente. (D2)

No primeiro, no EDX, eu senti dificuldade em anexar as informações. Porque o tipo de arquivo que ele falava lá, só poderia ser zipado. Ele definia um arquivo específico e eu não tinha este tipo arquivo. Senti dificuldade de incluir as informações lá no portal. No segundo, no Moodle, eu fiquei um pouco perdida também. De visualizar onde que estava as coisas, onde eu queria ir... Eu não achei de fácil acesso e não visualizei fácil, não consegui. A área de anexo não deixa claro o tipo de arquivo. Também tive dificuldades de anexar. No último, no Edmodo, ele era bem mais parecido com o que o que eu uso. Eu só pego o arquivo, escolho lá a disposição para incluir e arrasto e ele aceita. Então, achei mais dinâmico isso. Ou tem um ícone com o clipe. Então, ele é visualmente mais tranquilo de anexar. (D3)

\subsubsection{4}

\section{Síntese da utilização dos AVAs}

A partir das verbalizações dos entrevistados gestores, educadores e designers, podemos constatar que a maioria dos gestores e educadores (cinco dentre os seis) já havia utilizado ao menos um dos ambientes virtuais disponíveis. Já os três designers participantes não haviam experimentado algum dentre os três tipos de ambientes antes desta pesquisa. 
Percebemos que dos 9 participantes, 8 sinalizam a facilidade de utilização do ambiente Edmodo em situações de ensino-aprendizagem. Os entrevistados também apontam como um ponto positivo no Edmodo o fato de ele propiciar as práticas de interação entre educadores, educandos e conteúdo, além de facilitar o uso de gêneros multimodais.

Entretanto, a participante G3 trouxe o alerta quanto ao fato de o Edmodo não favorecer a apresentação da totalidade das etapas ou fases de um curso a serem percorridas. E o participante D1 destacou como um ponto negativo no Edmodo o risco da dispersão dos educandos somada à dificuldade de eles acompanharem as postagens naquele tipo de ambiente.

\section{2 .2}

\section{A avaliação dos Ambientes Virtuais de Aprendizagem nesta pesquisa}

Nesta seção será apresentado e discutido como os participantes gestores, educadores e designers avaliam os Ambientes Virtuais de Aprendizagem que lhes foram disponibilizados. O intuito é verificar os limites e as potencialidades que os AVAs oferecem aos seus usuários. Serão analisadas as características, as funcionalidades e as adequações na visão dos participantes.

\subsubsection{1}

\section{A avaliação dos AVAs pelo grupo de gestores}

Perguntamos ao grupo de gestores se a disposição e a organização das funcionalidades nos Ambientes Virtuais de Aprendizagem são adequadas para realizar cursos na modalidade a distância. Obtivemos as seguintes afirmações:

[...] eu percebo que o Edmodo é o melhor, para visualização. Os outros você tem que entrar em muitas abas para você conseguir verificar alguma coisa. E isso para o aluno dificulta. Porque nós temos alunos que conseguem utilizar estas ferramentas, mas outros ainda estão iniciando esse processo de utilização da tecnologia. Não conseguem gerenciar um e-mail. Então quando entram em um ambiente que muito difícil que você tem que mexer muito, geralmente eles acabam até desistindo. (G1)

Sim eu acho [...] eu acredito que o Edmodo sai um pouco na frente em relação à criação do curso, porque para encontrar o menu e o botão de criar curso ele está mais intuitivo. O EDX não está no local onde eu achei que estaria o botão criar curso. Por 
este motivo eu acho que a navegação do EDX ficou um pouco comprometida em relação às outras. A do Moodle eu já conhecia então ficou quase que automático. (G2)

Eu acho que sim. Eu acho que os três são adequados. Depende da... quer dizer entre o EDX e o Moodle de um lado e o Edmodo de outro, talvez eu tendo a necessidade de tipos de cursos diferentes. Mas acho que todos estão adequados. Eu só acho que, por exemplo, o EDX, eu travei com a coisa de como configurar avaliação, mas eu também não fui a fundo, né. Não foi estudar com ele funciona. Então talvez a questão da avaliação é que não esteja tão clara, tão direta como outros elementos dele, para quem está configurando um curso. Tive bastante dificuldades de encontrar isso. (G3)

Reconhecemos nas verbalizações dos gestores pesquisados que, quando os ambientes são complexos e de difícil entendimento pelos educandos, eles acreditam que isso tende a desestimulá-los a participar e a continuar com os estudos. Percebemos nas expressões da gestora G1 uma preocupação com os desafios da inclusão digital, que ainda é uma realidade na educação brasileira. Assim, também constatamos nas afirmações da G1 que a dificuldade em utilizar os Ambientes Virtuais de Aprendizagem pode desestimular os educandos, inclusive acarretando evasões nos cursos a distância.

Notamos, além disso, nas expressões dos gestores, que ambientes que possuem características e funcionalidades diferentes tendem a ser mais adequados a formatos também específicos de cursos. Isso fica evidente nas afirmações da G3 sinalizando que: "Depende da... quer dizer entre o EDX e o Moodle de um lado e o Edmodo de outro, talvez eu tendo a necessidade de tipos de cursos diferentes".

Perguntamos aos gestores, dentre os três Ambientes Virtuais de Aprendizagem que já experimentaram, qual deles reconhecem como o mais fácil e o mais difícil de utilizar.

O mais fácil é o Edmodo. Achei o Edmodo melhor do que o Moodle. Por eu já ter trabalhado no Moodle, eu achei o Edmodo melhor. O mais difícil é o primeiro. O EDX. Ele é o mais difícil. (G1)

Eu senti mais facilidade no Edmodo mesmo conhecendo o caminho do Moodle. Eu gostei da navegação para criar cursos no Edmodo. O que eu tive mais dificuldade, problemas para encontrar elementos para o planejamento da aula foi o EDX. (G2) 
Eu achei o EDX o mais difícil. O mais fácil eu ficaria entre o Moodle e o Edmodo. Talvez o Edmodo seja mais fácil, só que eu também acho que ele não serve para qualquer tipo de curso. Teria esta ressalva. Apesar de ele ser fácil. (G3)

A partir das considerações dos três gestores, constatamos que o Edmodo é o ambiente mais fácil de utilizar, e o EDX o mais difícil. Consideramos também em suas afirmações a sinalização de que determinados tipos de cursos demandam ambientes especificamente elaborados. Sendo assim, temos na visão dos gestores a importância de considerar o perfil de educandos, bem como o tipo de curso a ser oferecido no âmbito da preparação de Ambientes Virtuais de Aprendizagem.

Com isso, perguntamos também aos gestores, agora de modo mais direto, quais critérios precisam ser considerados, na visão deles, na escolha de Ambientes Virtuais de Aprendizagem. Expuseram suas percepções conforme segue:

Flexibilidade desse ambiente, possibilidade de maior interação entre estudantes. Então, verificar, fazer o gerenciamento...e também tem que ser uma coisa muito mais objetiva, não pode ter muita dificuldade em você acessar as abas. (G1)

Acho que o critério seria a experiência do usuário, que no caso são os alunos. A gente teria que considerar o momento, as ferramentas tecnológicas contemporâneas que os alunos estão usando para escolher a plataforma que mais se encaixa [...]. E também a questão da estabilidade da ferramenta e confiabilidade nas suas propostas de aula. (G2)

A existência de suporte técnico na Instituição. Eu acho que a possibilidade de customização. Não em ordem de importância, são diferentes. Não estou colocando de ordem de importância não. A existência de ferramentas que sejam flexíveis. Eu acho que o Edmodo oferece muita coisa em termos de tipos de atividade, elementos, para você usar... em html... que até sugerem tipos de atividades que eu não tinha pensado. Imagem que você dá o zoom, outras questões, tipos de problema. [...]. Então eu acho que uma coisa é você escolher um ambiente para ser um ambiente institucional de uma organização, de uma escola, de uma universidade. Eu acho que para ele ser um o ambiente institucional ele tem que ter um nível de flexibilidade, ele tem que ter suporte técnico para conseguir adequar. E para resolver isso você também precisa conhecer as necessidades do público. [...]. (G3) 
Observamos nas respostas dos gestores a demanda por aspectos relacionados à flexibilidade, à facilidade na promoção de interação entre usuários, além da necessidade de atualização dos ambientes com outras tecnologias contemporâneas.

A partir disso, perguntamos aos gestores, entre os três Ambientes Virtuais de Aprendizagem disponíveis para sua utilização, qual deles melhor oferece as funcionalidades adequadas a cursos de Educação a Distância.

Edmodo. (G1)

Acredito que o Moodle pelo seu modelo construtivista, ele está mais voltado para a educação a distância. Ele foi concebido com foco na EaD. Agora eu gostaria que a navegação dele acompanhasse as tendências das outras ferramentas contemporâneas, como as redes sociais e outros aplicativos. (G2)

Não sei. Depende do curso. Depende se é um curso mais tradicional ou se é um curso mais flexível, mais aberto. (G3)

Diante das respostas dos gestores, percebemos diferentes concepções e percepções acerca da oferta de funcionalidades disponíveis em Ambiente Virtual de Aprendizagem. $\mathrm{O}$ ambiente mais adequado pode ser um conceito relativo, mas demanda essencialmente flexibilidade, atualização e alinhamento com as teorias construtivistas da aprendizagem abordadas por Vygotsky (1984), (1989); Piaget (1974) e Wallon (1986), (2007).

\subsubsection{2}

\section{A avaliação dos AVAs pelo grupo de educadores}

Após indagarmos sobre a avaliação dos AVAs aos gestores, passamos a perguntar aos educadores participantes se a disposição e a organização das funcionalidades nos Ambientes Virtuais de Aprendizagem são adequadas para a realização de cursos na modalidade a distância.

Eu acredito que as três plataformas dão conta. Dão conta de fazer isso. Cada uma tem, digamos assim, uma limitação [...]. Eu peguei todos os conteúdos e consegui aplicar o mesmo conteúdo da primeira, na segunda e na terceira. Então elas cumpriram isso. E depois eu fui lá e acessei no modo visitante ou de aluno e consegui ver que funciona para ensino a distância. (E1)

No caso do Moodle sim. Apesar que eu acho que... eu vejo que o Moodle ele meio que estagnou nos seus recursos e nas suas 
ferramentas. Eu acho que talvez a gente precise de mais investimento em processos de customização, mais pesquisas para que a gente possa voltar a ampliar as possibilidades de utilização deste ambiente. No caso do Edmodo eu acho que você possibilitar a utilização de um ambiente que se assemelha a uma rede social, eu vejo com simpatia este tipo de possibilidade de uso do recurso. Já no caso do EDX eu achei ele um ambiente muito fechado, talvez pela sua natureza de seu ambiente mais massivo. Talvez isso dificulte um pouco mais esta sua possibilidade de utilização. (E2)

Eu acho que o do Moodle é bem adequada. O do Moodle eu acho que sim. Os outros dois como são ambientes que eu não conhecia. Então tive mais dificuldade. Talvez justamente por não os conhecer e nunca ter tido a oportunidade de mexer com nenhum dos dois, eu tive um pouco mais de dificuldade de encontrar, mas me parece que são bons. (E3)

Após analisarmos essas observações, constatamos que os educadores E2 e E3 tenderam a sinalizar o Moodle como o ambiente mais apropriado para a EaD. Lembramos aqui que esses dois educadores já haviam utilizado o Moodle e possuem formação no campo da Educação, são licenciados em Pedagogia. Já o educador $\mathrm{E} 1$ afirmou que os três ambientes são adequados para a $\mathrm{EaD}$. O educador E1 não havia utilizado nenhum dos três ambientes antes da participação nesta pesquisa, além disso, possui em sua formação inicial o curso de bacharelado em Filosofia.

Diante disso, perguntamos aos três educadores qual, dentre os três Ambientes Virtuais de Aprendizagem que experimentaram, reconhecem como o mais fácil e o mais difícil de utilizar. Expuseram suas percepções conforme segue:

Como as minhas exigências foram muito bem atendidas depois de algum tempo. E não foi tanto tempo assim, no EDX, eu aponto o EDX como o mais fácil de utilizar. E o mais atraente inclusive visualmente [...]. Um programa mais duro ou que tenha muitas gavetas e que tem que entrar para encontrar os objetos lá atrás, cria já um certo distanciamento. E eu tenho isso claramente para mim. Talvez os outros profissionais não sintam isso. [...]. Então o EDX, evidentemente, ele dá mais prazer a mim, prazer mesmo, de fazer uso e de encontrar aquilo que eu quero. Eu vou conseguir atender ao aluno nisso. Então ele é o primeiro. $\mathrm{O}$ segundo, e obviamente considerando esse tipo de coisa é o Moodle e o terceiro é o Edmodo. E obviamente, você poderia até questionar o fato assim: - se o Edmodo, talvez ele tenha realmente menos recursos, ele é o mais fácil de usar porque você não pode, não tem muito o que fazer nele. É só isso. Você vai fazer e essas são as opções. Então você não tem que ficar colocando florzinhas em volta. Digamos assim. A grande questão é que quando a gente 
trabalha com comunicação e trabalha com educação e quer transmitir ao outro algum conhecimento ou alguma informação, nem sempre você faz isso só com palavras. Nem sempre faz isso com as palavras e as vezes imagens aplicadas de forma a passar essa informação[...]. Então assim, até que ponto essa digamos 'facilidade' apresentada pela limitação é realmente uma facilidade. Sabe? Porque eu vou ficar incomodado. Eu não estou passando tudo que eu tenho aqui. Então assim: - é fácil? mas eu não quero simplesmente colocar e lançar isso no ar porque eu não tenho essa outra opção. [...] (E1)

O mais fácil, o Edmundo. E o mais difícil é o EDX. (E2)

O mais fácil é Moodle. O mais difícil é o EDX, justamente pelo fato do idioma. (E3)

Percebemos nas declarações dos educadores que a opção por um determinado Ambiente Virtual de Aprendizagem pode envolver questões ideológicas, políticas, de formação etc. Notamos isso nas diferentes concepções e percepções verbalizadas pelos educadores E1, E2 e E3. Assim, a construção de novos Ambientes Virtuais de Aprendizagem ou escolhas de ambientes já existentes perpassa inúmeros critérios e elementos que vão refletir nas características desses espaços virtuais.

Identificamos que dois dos educadores reconhecem o ambiente EDX como o mais difícil de se utilizar. Mas, curiosamente, o educador (E1) que não havia utilizado nenhum dos ambientes, antes da pesquisa, identificou o EDX como o mais fácil de usar. O educador E1 possui formação em Filosofia, mas se reconhece como designer por já ter uma vasta experiência profissional no campo do Design. Esse educador nos fala do prazer em utilizar o ambiente EDX. Em seus dizeres afirma: "Então o EDX, evidentemente, ele dá mais prazer a mim, prazer mesmo, de fazer uso e de encontrar aquilo que eu quero".

Passamos então a perguntar aos educadores, agora de modo mais direto, quais critérios precisam ser considerados na escolha de Ambientes Virtuais de Aprendizagem:

Seguindo a minha posição, a primeira coisa é a facilidade de uso. Isso envolve não só a interface....a interface tem que ser amigável, tem que ser intuitiva. E isso significa o quê? Eu acho que intuitivo diz alguma coisa relacionada a um elemento anterior. [...]. Então quando você olha...Ah! eu já fiz aqui em algum lugar, está lá. Então esse é um primeiro critério. [...]. Então acredito que assim: ainda assim esses três programas poderiam ter um elemento a mais que desse uma contribuição para essa facilidade, no primeiro momento que você entra. Um exemplo: 
Digamos que eu entre no EDX. Aí tem lá em cima assim: uma apresentação. Os programas têm isso. Uma videoaula, assim com 2 minutos em que o programa apresenta como nos diversos programas, um anúncio falando daquilo que os programas têm. [...]. O segundo ponto é: oferecer recursos, sabe? Oferecer o máximo de recursos. Porque aí você cerca a questão. Você vai pegar um usuário que precisa de pouca coisa e vai pegar um usuário que precisa de muito recurso. Do ponto de vista do programa isso é interessante. Porque não é só porque ele atende a um leque maior de usuário. É porque ele atende um usuário que começa usando pouco e pode usar muito depois. O terceiro ponto que também eu acho que que não é o terceiro ponto, do ponto de vista de uma hierarquia não. É um dos pontos que está em pé de igualdade que é o de segurança. E é o que eu não pude avaliar. Segurança é fundamental. Tanto para aqueles que produzem, porque as vezes é um conteúdo que é seu, e você quer garantir que isto tenha direito, proteção aquilo que está saindo. [...] eu acho que eu não experimentei, não vi, seria a possibilidade, e eu acho que todos eles devem ter, não sei, de alguma forma tem, disso ser transformado em um material separado daquele ambiente como um formato de plataforma independente, como PDF e outros. Que pode ser depois impresso. Sei lá... o aluno tem aquilo ali, mas ele não tem tempo de ficar acessando a internet. Aí ele vai gera algum arquivo de outro modelo para ele poder de repente imprimir e levar com ele para outras situações. Isso é uma quarta opção. [...] Bom, eu não sei como que é em relação com os dois outros, mas o primeiro eu sinto que ele tem essa capacidade de hierarquização. Ele permite, eu imagino que ele permita e isso é interessante, de criar realmente cursos no sentido assim de módulos que vão sendo agregados e vão virando conteúdos muito mais amplos e que se conectam. [...]. Mas quando eu vejo a possibilidade de um programa como é o EDX que propõe um curso, ele tem coisas que eu não utilizei como seções e subseções. Eu falei: - nossa! Isso aí permite fazer muita coisa interessante. Imagino que se permita fazer muitas coisas interessantes que eu nem experimentei. Então esse tipo de... Talvez seja o quinto item, né? Que é essa, talvez, modularização e interconexão de conteúdos que é uma característica, a essência da internet, né? [...]. (E1) (grifo nosso).

Eu acho que são vários: funcionalidades, recursos disponíveis, o fato de você possibilitar a customização do ambiente... no caso do Moodle ele tem uma vantagem por ser um software livre... navegabilidade... a própria interface do ponto de vista da sua organização, estruturação, ...como que o ambiente está organizado, como os seus recursos estão disponíveis... Eu acho que uma série de questões pedagógicas, de como os alunos vão se interessar ou não por aquele ambiente, por aquela interface. Então uma série de critérios que a gente poderia delinear para a escolha de ambientes. (E2)

Esse do idioma é um deles. É um critério que tem de ser, porque nem todo mundo domina um outro idioma. A gente tem dificuldade às vezes com o próprio português. Então com idioma 
diferente acho que dificulta esse trabalho de qualquer professor. Ainda mais pensando às vezes em quem vai trabalhar com esses ambientes, são pessoas que têm ainda menos acesso do que quem está aqui. Estou pensando nele não só da proposta universitária, mas de outros cursos também. Então às vezes acho que isso pode ser um "dificultador". (E3)

Constatamos, a partir dessas verbalizações, que o educador E1 indicou como critérios a facilidade de uso, a multiplicidade de recursos, a segurança e a proteção no ambiente, a possibilidade de gerar materiais a serem consultados fora do ambiente, além da possiblidade de hierarquização e modularização de cursos. O educador E2 destacou que são inúmeros os critérios a serem adotados, mas manifestou uma ênfase na possibilidade de customização do ambiente para favorecer a flexibilidade. Já o educador E3 destacou a importância de idioma disponível no ambiente, uma vez que a tradução para a língua portuguesa do Brasil no EDX ainda não está completa.

Perguntamos também aos educadores qual, dentre os três Ambientes Virtuais de Aprendizagem disponíveis para sua utilização, melhor oferece as funcionalidades adequadas a cursos de Educação a Distância.

Eu acredito que assim, tendo apreciado dos três mais ou menos com mesmo tempo. O EDX, se ele não oferece, ele pelo menos tem uma interface que faz a gente acreditar que sim. Sabe assim?... Pode ser que os outros também tenham, esteja escondido. Porque tem programa que é assim. Tem programa você olha para ele e ele não apresenta quase nada, mas você começa a abrir os menus e as gavetas, tem um mundo debaixo daquilo ali, escondido. [...]. Então do ponto de vista da exposição, o EDX para mim, tendo tirado mais ou menos o mesmo tempo para apreciar cada um deles, ele se mostrou mais adequado neste sentido. Parece potencialmente muito mais robusto, muito mais... tem mais oferta para esse tipo de necessidade. (E1)

O Moodle. Talvez pelo fato dele já estar mais solidificado no mercado como um ambiente de aprendizagem. Pelo fato dele ser e ser num só ser livre que permitiu muitas universidades muitas corporações customizarem, criarem novas interfaces, criarem novos ambientes. Apesar de eu achar que ele de uns anos para cá deu uma estagnada. Mas o Moodle, sem dúvida alguma parece ser o mais indicado ainda para desenvolver cursos a distância. (E2)

É difícil de falar com apenas um acesso. Então, acabo ficando tendencioso pelo Moodle, mas me parece que o Edmodo, eu tive a impressão que ele também é mais tranquilo de trabalhar. (E3) 
Identificamos nos dizeres dos entrevistados E2 e E3 que o Moodle, em suas concepções, é o ambiente que melhor oferece as funcionalidades adequadas a cursos de Educação a Distância. No entanto, o educador E2 alertou para o fato de o Moodle necessitar de uma renovação profunda na atualidade. Segundo o participante E2, baseando-se em sua experiência profissional, afirmou que as inovações estruturais e substanciais do Moodle encontram-se estagnadas. Já o educador E1 destacou o ambiente EDX como aquele que potencialmente dispõe das melhores funcionalidades para cursos na modalidade a distância.

\title{
6.2.2.3
}

\section{A avaliação dos AVAs pelo grupo de designers}

Assim, após indagarmos aos educadores sobre a avaliação dos AVAs, passamos a perguntar aos designers participantes se a disposição e a organização das funcionalidades nos Ambientes Virtuais de Aprendizagem são adequadas para realizar cursos na modalidade a distância.

\begin{abstract}
Eu acho que são, mas eu acho que o ideal seria o professor fazer, principalmente ali no Moodle, um curso antes para saber fazer Moodle. Nem que seja uma oficina, um workshop, pode ser uma coisa de um dia, mas para dar um norte ali. Eu acho que as funcionalidades não são tão intuitivas assim, o que eu achei mais intuitivo foi o EDX e o Edmodo talvez. (D1)

Acho que só a terceira novamente. Só a Edmodo. As outras duas completamente não. Não são adequadas, não são intuitivas e acho que falham muito na questão da autoexplicação. Num curso a distância que eu espero é a ferramenta...enfim. As ações que eu venha realizar sejam mais intuitivas possíveis, já que vou estar sozinho, né. Então com a exceção da Edmodo, não recomendo as outras duas. (D2)
\end{abstract}

Sinceramente, as duas primeiras plataformas não. Acho que a última sim [Edmodo], acho que ela é mais fácil. Acredito que é mais fácil para quem vai incluir as matérias e também para quem vai consultar como aluno. Achei ele mais fácil. (D3)

A partir dos depoimentos dos três designers, constatamos que, de modo geral, os ambientes necessitam de aprimoramentos na disposição e na organização das funcionalidades para a oferta de cursos a distância. A demanda por uma organização clara e perceptível no ambiente aparece como uma demanda, visto que a expressão “intuitiva” aparece em suas verbalizações. 
Isto posto, passamos a perguntar aos designers quais, dentre os três Ambientes Virtuais de Aprendizagem que experimentou, reconhecem como o mais fácil e o mais difícil de utilizar.

O mais fácil para mim foi o EDX. O Edmodo também seria fácil, o problema é que ele... aí eu não sei se era o meu computador, eu tive que repetir várias vezes a mesma coisa. Por exemplo, eu fazia um post porque eu queria colocar um vídeo junto com o post. Aí eu publicava e ia sem o vídeo. Aí eu tinha que ir lá, editar publicação, anexar vídeo. Aí ele não ia... aí dava de novo, ele ia. Sabe aquele troço meio que meio 'bugado'. Mas a diagramação dele eu achei muito bonita e muito intuitiva também. O mais fácil foi o EDX, seguido do Edmodo, e o mais difícil foi o Moodle, eu achei. (D1)

Mais fácil é o Edmodo e a mais difícil seria a primeira, seria o EDX. (D2)

O mais fácil é o Edmodo. O mais difícil é o primeiro. O EDX. (D3)

Considerando que os três designers não haviam utilizado os ambientes antes da participação nesta pesquisa, suas expressões nos revelaram um contraste de opiniões. Não houve consenso entre o mais fácil, o mais difícil e qual dentre os três estaria em um nível intermediário.

Após essa constatação, passamos a perguntar aos designers quais critérios precisam ser considerados na escolha de Ambientes Virtuais de Aprendizagem.

Olha, se o seu professor vai ter treinamento, eu acho. Porque, por exemplo, da maneira como eu tô criticando o Moodle, mas nesse sentido de "intuitividade". Eu caí de paraquedas para tentar montar a aula, [...], eu já aprendi muito mais coisas. Eu acredito se eu ficasse usando ele durante um mês, de repente posso até achar ele superior aos outros. Mas a gente sabe que no dia a dia as pessoas também às vezes não vão ter tanto tempo disponível... tudo mais...Isso tudo impacta no tempo em que o professor poderia tá pensando no conteúdo mesmo e ele tá quebrando a cabeça para conseguir fazer, programar a aula na plataforma [...]. Quanto menos retrabalho melhor. Eu quero perder tempo trabalhando no conteúdo. Não quero perder tempo fazendo queda de braço com programa. (D1)

Acho que comunicação principalmente. Facilidade de comunicação e não sei...seria o caso de utilizar ferramentas ou meios de acesso baseados em outras interfaces que as pessoas já estão acostumadas: como e-mail, redes sociais. Acho que seria um bom ponto de partida. Porquê da forma como que tá aqui não 
me soa como se fosse algo que eu já tenha visto antes, em outra interface... (D2)

Quanto mais fácil o layout, mais visual...Porque eu imagino que quem faz um curso on-line, a distância, tem que levar em consideração que são várias idades e níveis de educação diferentes. Então acho que usar o recurso de ícone visuais fáceis de identificação, para mim é ótimo. Mas se não tiver escrito também... Por exemplo: anexar... se não tiver escrito anexar, alguém que não tem tanta facilidade com informática, não seja habituado àquilo, terá dificuldade. Ou mesmo para baixar. Então acho que tem que ter esses elementos. Acho que a preocupação maior teria que ser com o layout. Tornar mais fácil a absorção e a identificação dos elementos, para localizar e ser menos esquemático. (D3)

Notamos, a partir dos depoimentos dos designers entrevistados, a valorização de critérios relacionados à intuição dos usuários. Sinalizam a importância de aspectos relacionados à linguagem e a elementos utilizados que poderão facilitar a faculdade dos usuários em perceber, reconhecer e discernir quais ações podem ser realizadas nos ambientes.

Após essa observação, questionamos quais, dentre os três Ambientes Virtuais de Aprendizagem disponíveis, melhor oferecem as funcionalidades adequadas a cursos de Educação a Distância.

As funcionalidades são muito parecidas, é até injusto, eu não me sentir muito à vontade em dizer o que um tem que o outro não tem. Mas eu gostei mais do EDX, eu senti mais essa segurança, embora ele seja mais simples, ele dá menos opção me parece. Opção que eu digo... o questionário lá do Moodle, ele tem um milhão de opções e lacunas para você ficar ali ajustando. Eu nem experimentei todos aqueles parâmetros. Talvez muita gente também não vai querer. Claro que assim, é legal saber que tem aquilo? É, mas... se dá para simplificar particularmente eu prefiro isso. Gostei mais do EDX. (D1)

Edmodo. (D2)

O último, o Edmodo. Eu até anotei aqui, porque eu achei interessante que ele tem bem separado: matéria, tarefas, enquete, opinião... Nele eu consegui incluir melhor as informações. Achei que os alunos, conseguiriam encontrar melhor as informações. E o professor também... quem tiver interessado em anexar as informações, ficaria mais fácil. Ficou separadinho, mas de uma forma mais interessante. (D3) 
Acompanhando a avaliação que expressaram quanto à facilidade de uso, isso coincidiu com a opinião acerca de qual, entre os três ambientes, melhor oferece as funcionalidades adequadas a cursos de Educação a Distância. Neste caso temos o EDX, na visão do designer 1, e o Edmodo, na visão dos designers 2 e 3 .

\subsubsection{4 \\ Síntese da avaliação dos AVAs}

Percebemos que os entrevistados sinalizam como ponto positivo o fato de alguns Ambientes Virtuais de Aprendizagem apresentarem uma interface habitual e familiar, revelando, assim, uma concepção de uso que valoriza a intuição dos usuários. Para grande parte dos pesquisados, a adesão de educandos e educadores ao ambiente tornar-se-á mais propícia se encontrarem uma área de interação já conhecida. Ademais, a construção de aulas e atividades pelos educadores também será uma tarefa mais fácil.

Essa concepção em que se propõe oferecer um ambiente virtual mais "intuitivo" e de apresentar elementos familiares aos usuários presume-se estar alinhada ao método indutivo e, de modo particular, às formulações teóricas de Johann Heinrich Pestalozzi.

Para Pestalozzi (1946), o método intuitivo pressupõe uma abordagem indutiva, em que se deve ensinar a partir do conhecido para o desconhecido, do particular para o geral, do concreto para o abstrato. Considerando essa concepção, têm-se como propostas situações nas quais os usuários possam descobrir por si mesmos como utilizar o Ambiente Virtual de Aprendizagem sem a necessidade de um curso específico para isso.

Podemos considerar que, na visão dos entrevistados, um Ambiente Virtual de Aprendizagem necessita disponibilizar aos seus usuários aspectos relacionados à flexibilidade, atualização e facilidade na promoção de interação entre usuários educandos, educadores e conteúdo. Neste sentido, observamos que as demandas expressas nas opiniões dos pesquisados alinham-se com as teorias construtivistas da aprendizagem abordadas por Piaget (1974) e Vygotsky (1984) e (1989). 


\subsection{3}

\section{A relação entre AVAs e o campo do Design}

Nesta subseção deste capítulo, serão apresentados e discutidos as aproximações e os distanciamentos entre Ambientes Virtuais de Aprendizagem e o campo do Design, na visão dos participantes gestores, educadores e designers. A intenção é verificar se os participantes reconhecem a viabilidade de uma interdisciplinaridade entres os campos do Design e da Educação a Distância, no que se refere à construção de novos Ambientes Virtuais de Aprendizagem.

\subsubsection{1}

\section{A relação entre AVAs e o campo do Design na visão dos gestores}

Iniciamos perguntando aos gestores se o campo do Design pode contribuir na construção de novos /ou na realização de melhorias em Ambientes Virtuais de Aprendizagem. Ao indicarem afirmativamente ou negativamente, pedimos que explicassem a sua resposta.

Sim. Eu acredito sim. E é justamente nesse item... o design, a visualização, isso aí vai ajudar muito. No desenvolvimento desses cursos, na participação desses alunos. Porque o nosso público hoje está aumentando cada vez mais na educação a distância. E o ambiente virtual ele pode ser o cartão de visita. Então ele tem que ser o mais interativo possível, tem que ter um design atraente. Acho que a pessoa tem que sentir vontade de abrir aquela plataforma para poder trabalhar. Não pode ser uma coisa muito difícil não. Tem que ser algo bem prazeroso. Acho que é mais por aí mesmo. Observar o ambiente e trazer esta interatividade para a Educação a Distância. (G1)

Sim. O designer é o profissional que tem as melhores chances de construir um modelo para cursos a distância. Para elevar ao máximo nível de inteligência coletiva, de interação entre os alunos. Acho que o designer tem em seu cerne a tendência de encontrar soluções para estes problemas de comunicação, que a gente encontra hoje nas plataformas. Acho que o designer é o profissional ideal para contribuir para a solução de problemas na EaD. $(\mathrm{G} 2)$

Sim. Acho que sim. A partir disso que falei...da consideração das necessidades dos usuários, dos educadores, da instituição. E nesse sentido eu acho que é muito mais na adequação. Já se tem tantos ambientes já desenvolvidos. Eu acho que tem muita gente já desenvolvendo. Talvez o esforço pudesse ser mais no sentido de ampliar a flexibilidade dos ambientes já existentes para que eles pudessem dar conta de outros 
formatos de ensino-aprendizagem. Eu lembro que, quando eu fiz as entrevistas para o meu mestrado, os educadores reclamavam muito porque eles tinham uma configuração de professor-aluno que era muito diferente. Não era um professor apenas para 30 alunos na disciplina de projeto. Eram dois educadores principais e mais seis colaboradores que não estavam o tempo todo com os alunos. Então, em geral, os ambientes eles pensam do "um para muitos". Eles estão baseados em geral no esquema de ensino que é da dispersão da informação. De um professor que passa informação para muitos. $E$ naquele caso era uma forma de ensino que baseava muito mais na interação. $E$ dependia da interação de muitas pessoas diferentes com background diferentes. Então como fazer isso caber dentro de um ambiente que por definição depende de ter "um" professor. Até tem figuras de tutor, enfim, poderia tentar. Mas eu acho que, por exemplo, valeria a pena um trabalho de design que adequasse o Moodle a esse tipo de situação de aprendizagem. Permitisse modos diferentes, com educadores diferentes. Eu acho que nesse sentido. (G3) (grifo nosso).

Ao analisar as verbalizações mencionadas, é importante lembrar que a gestora 1 possui formação prioritariamente no campo da Educação, e os gestores 2 e 3 possuem formação stricto sensu no campo do Design. Contudo, notamos uma convergência de opiniões acerca do potencial do Design para a participação na construção de novos Ambientes Virtuais de Aprendizagem.

Após essa constatação, passamos a perguntar-lhes quais as perspectivas que têm para o futuro dos Ambientes Virtuais de Aprendizagem e quais alterações esperam ou anseiam que ocorram nos ambientes. Demonstraram suas expectativas conforme segue:

Eu acredito que no futuro estes ambientes serão cada vez mais simples e bem mais objetivos. Acho que cada vez mais a evolução desses objetos de aprendizagem, do próprio ambiente, vai levar a ter facilidade, como nós temos hoje com as redes sociais. Não vai ser nada muito difícil não. $\mathrm{E}$ as atividades também vão acompanhar mais, porque nós sabemos que na educação a distância a disciplina do estudante é que comandará justamente os seus conhecimentos. Então se ele tem o contato cada vez maior, que seja bem mais aprazível, que ele tenha vontade de verificar, de estudar, vai sempre vai sempre melhorar mais o aprendizado. (G1)

Eu acredito que os ambientes virtuais de aprendizagem eles poderiam ser utilizados mais offline. Ele poderia tornar o ensino mais híbrido, trazendo para dentro da sala de aula algumas ferramentas de avaliação da plataforma. Então o professor poderia fazer o uso da plataforma como repositório de material, 
como meio de interação extraclasse entre os alunos. Acho que o AVA está subutilizado ainda na educação presencial. Eu gostaria de ver mais ambientes virtuais na educação presencial. (G2)

Talvez essa tendência de se aproximar mais da rede social seja um forte, né. Por conta da pregnância deste tipo de espaço de interação. E acredito que isso pode acabar vazando mais para os ambientes de ensino. Uma vez que as pessoas estão aprendendo tanto nas redes. Interagindo diariamente na trilha de conhecimento e informação. Acho que uma questão é essa. E a outra questão é da flexibilidade. Por outro lado, tem que ter flexibilidade. É claro que um ambiente ele vai ter... em geral, os ambientes partem de um pressuposto de uma concepção pedagógica para poder estruturar o que ele vai oferecer. Mas acho que o mesmo tempo um ambiente muito sucesso seria um ambiente muito flexível, que conseguisse se adequar às situações e estruturas diferentes. (G3)

Notamos nas verbalizações dos gestores o anseio por ambientes que sejam mais fáceis, com possibilidade de serem utilizados em situações de ensino híbrido e apresentem semelhanças com as tecnologias contemporâneas, tais como as redes sociais digitais.

Isto posto, perguntamos aos gestores se, durante as suas atuações na Educação a Distância, trabalharam com designers na equipe. Se afirmativo, questionamos como era a atuação do(s) designer(s).

Não. Nós não tivemos designers na equipe. Já era a plataforma pronta. A gente sempre utilizou o mudo mesmo sem nenhuma alteração maior. Eu não tive este contato não.

Sim. Eu já trabalhei com designers instrucionais, porém esses designers não tinham formação em Design. Eles eram das áreas de tecnologia e atuavam na área técnica. Eu senti a falta da atuação do designer, na interface com a plataforma. Não existia o Bacharel. Existia o design instrucional que às vezes era confundido com designer. Acontece muito.

Sim. Mas a atuação desse designer era mais em termos de produção de material, diagramação e ilustração. Eu trabalhei como designer também. A minha função era meio flutuante.

Percebemos com essas verbalizações que em algumas situações a atuação dos designers ainda é algo incipiente no âmbito da inferência em Ambientes Virtuais de Aprendizagem.

Após essa verificação, perguntamos aos gestores se gostariam de acrescentar alguma informação ou comentário, ou descrever algo mais sobre a experiência de 
uso dos três ambientes. Os gestores G1 e G2 quiseram comentar. Seus depoimentos estão apresentados a seguir:

Eu gostaria de agradecer o convite em poder participar desta pesquisa. E acredito também que ela vai possibilitar novos olhares sobre o design desses ambientes virtuais de modo a possibilitar a aprendizagem dos alunos. E hoje a gente sabe que educação a distância ela é não é mais uma alternativa, ela já é uma verdade. Ela tá aí se afirmando cada vez mais. A tendência do crescimento do número de alunos ela tem avançado cada vez mais no decorrer desses tempos nossos. Então acho que a Educação a Distância ela tem que ser algo que estimule este estudante a buscar sempre mais, e o ambiente é fundamental. (G1)

Eu poderia acrescentar o que eu pesquisei no meu mestrado em relação às interfaces das plataformas e a representação icônica e dos signos e das ferramentas de usabilidade dos menus. Eles poderiam acompanhar a tendência das ferramentas contemporâneas, que é o caso do Facebook, Twitter, porque nem sempre essas plataformas eles conseguem atualizar as suas interfaces de acordo com as tendências. (G2)

A entrevistada G1 expõe sua expectativa de melhorias em Ambientes Virtuais de Aprendizagem com a aproximação entre Design e Educação a Distância. E o entrevistado G2 sinaliza a importância de os ambientes acompanharem as tendências das ferramentas contemporâneas.

\subsubsection{2}

\section{A relação entre AVAs e o campo do Design na visão dos educadores}

Assim como perguntamos aos gestores, questionamos os educadores participantes se o campo do Design pode contribuir para a construção de novos Ambientes Virtuais de Aprendizagem e/ou para a realização de melhorias nos existentes.

Claro. Se a gente olha para esse... Com referência para essas três plataformas, você vê claramente. Você olha para a primeira plataforma e para a terceira plataforma, falta design. Do meu ponto de vista, mesmo que esteja escondido e se tiver, mais um motivo, que falta design. Porque o design tem que explicitar isso. Falta. E o design tem que explicitar isso. E obviamente isso não é uma tarefa para o design simplesmente, mas para o design considerando que ele está atuando numa esfera que não é a esfera propriamente dele, que é da Educação. Acho que tem uma parceria aí. Tem que ter uma conexão com os profissionais que 
estão ligados a isso, e de alguma forma podem contribuir para isso funcionar melhor. Mas efetivamente sim. (E1)

Eu acho que sim. Eu acho que o Design é um campo muito amplo. Tem não só a questão mais gráfica da questão das interfaces, de questões que envolvem, por exemplo, os ambientes do ponto de vista mais técnico e mais tecnológico. Mas também o próprio campo do Design Educacional que já vem pensando também como o sujeito se relaciona com este ambiente. Eu acho que é um campo vasto de pesquisa de estudos nesta área que podem contribuir sim, com o desenvolvimento da Educação a Distância. (E2)

Com certeza. Justamente por esta expertise que os profissionais do Design têm, pessoalmente pessoal do design gráfico, não é isso? Acho que conseguem criar um ambiente com uma melhor acessibilidade, como que eu diria?... a palavra tá faltando aqui, mas acho que isso mesmo: acessibilidade, onde usuário teria uma visibilidade melhor de onde está cada ferramenta de onde ficaria, do que ele precisa, onde ele tem que adequar. (E3)

Notamos nas verbalizações dos educadores participantes a sugestão por propostas de aproximação entre os campos do Design e da Educação a Distância no âmbito da construção de novos Ambientes Virtuais de Aprendizagem. Destacamos, inclusive, o comentário do educador E2 ao se referir ao campo "Design Educacional".

Em seguida, perguntamos aos educadores quais as perspectivas que têm para o futuro dos Ambientes Virtuais de Aprendizagem e quais alterações esperam ou anseiam que ocorram com esses ambientes. Demonstraram assim suas expectativas:

[...] eu até penso que é muito mais uma questão de investir e direcionar recursos e profissionais especializados para esse nicho do que propriamente elaborar estratégias. Você já tem os recursos funcionando nas diversas áreas. [...] A toda hora sai uma nova mídia. Sai com opções. Eu acho que é muito mais ação que tenha por trás, obviamente, vontade e condições de bancar isso. Se você consegue colocar dinheiro e pessoas interessadas, do ponto de vista da tecnologia, você faz muito mais do que tá aí. O próprio Skype, em determinados tipos de uso a gente vê isso. Se você está numa videoconferência você está conversando e o sujeito pode acessar seu computador e ver coisas alterar no computador. Então você pode colocar um conteúdo para os seus alunos e continuar conversando com eles. Se você não quiser que a aula se dê assim: mandar conteúdo eles leem e depois te deem retorno. Está tudo aí é só talvez saber ajustar e ajuntar. (E1)

Eu acho que os canais... hoje nós temos vários canais de comunicação como as mais as chamadas redes sociais, como é o 
caso do YouTube, como é o caso do dos blogs, como é o caso das ferramentas de áudio... Hoje nós temos as facilidades dos aplicativos para smartphones...etc. Eu acho que é uma tendência. Não só o diálogo entre essas interfaces, mas a aproximação do uso dessa linguagem. Ou seja, da linguagem dos ambientes se aproximarem cada vez mais das linguagens dessas redes sociais, desses aplicativos para interfaces móveis. Eu acho que isso é uma tendência para o futuro. (E2)

Olha, o que eu imagino já tá até acontecendo e o que pode melhorar essas aulas em que o aluno tenha acesso, que já ficam ali gravadas. Ou aulas que são dadas on-line e que depois elas ficam disponíveis para o aluno. Então eu imagino que isso vai facilitar o acesso porque hoje eu vejo que muitos alunos que querem assistir a uma aula dessas eles às vezes têm dificuldade de assistir. Eu não sei se isso é pelo programa, se isso é pela questão da internet, o espaço de armazenamento de arquivos e acredito que tende a melhorar. Os links que podem ser feitos de dentro do ambiente virtual como sites para trabalhar um vídeo, uma música, eu acho que isso tudo ainda tende a melhorar. Você tá dentro do site E aí professor como exemplo um documentário e o aluno já acessa ali com mais facilidade. Ou ele já está ali pronto para ser visto, sem que o aluno precise de ir lá para o site, baixar para ver. E ele já vai estar ali com facilidade, dentre outras coisas...(E3)

Notamos, a partir dessas verbalizações, a expectativa e o interesse dos educadores por ambientes que possibilitem a convergência de mídias. Sugerem que novos ambientes apresentem flexibilidade em relação aos usos, considerando a integração com as redes sociais e os aplicativos para dispositivos móveis, tais como smartphones.

Diante disso, perguntamos aos educadores se em suas atuações na Educação a Distância trabalharam com designers na equipe. Se afirmativo, questionamos como era a atuação do(s) designer(s).

O educador E1 ainda não teve experiência profissional com a EaD. Já os educadores E2 e E3 afirmaram que em suas trajetórias no ensino a distância nunca tiveram a oportunidade de trabalhar com designers.

Em seguida, após essa verificação, perguntamos aos educadores se gostariam de acrescentar alguma informação, comentário, ou descrever algo mais sobre a experiência de uso dos três ambientes. Os educadores quiseram comentar:

Eu já até falei sobre isso. Acho que assim: me despertou para esse... para essa possibilidade... Obviamente, como professor eu tenho interesse em divulgar o conhecimento. Então eu não faria esse movimento de ir até isso. Até porque eu já tenho uma série 
de outras possibilidades que eu já as quais eu já atuo que tomam muito tempo. Eu não faria esse investimento. E com o convite da pesquisa, eu pude perceber que... até para um cara como eu que não usa smartphone, que limita muito atualmente... Eu era um "nerd", "fominha" de tecnologia na década de 1990. Até porque eu venho da eletrônica, da física. Na década de 2000 também eu era mais ou menos assim. Na medida que eu fui cada vez mais me voltando para aspectos mais de fundamentação teórica, eu fui me afastando disso. Então por esse afastamento também eu não tinha muito interesse em ver tudo isso. Ao entrar e perceber a facilidade e as possibilidades que tem isso, eu não sinto que eu tenho que fazer um esforço muito grande para ter um mínimo de retorno no uso desse tipo de instrumento, de ferramenta. Então isso me deixou atraído. [...]. Realmente foi muito bom poder participar disso e abrir minha cabeça para essas possibilidades. É o lado bom da tecnologia, é isso. Parabéns! (E1)

Não, não tem nada a acrescentar não. Tenho muito mais a aprender nessa área como uma pessoa que se interessa por este tipo de campo de conhecimento. Eu acho que eu tenho muito mais a aprender a conhecer do que, nesse momento, dar algum tipo de opinião mais balizada sobre a área, sobre o campo. (E2)

[...] com relação a essa questão de os designers participar, eu acho que é interessante. Porque até aonde eu sei, e lá dentro da própria UFMG a gente trabalhava com um pessoal que é programador. Eu acho que tem uma diferença muito grande desse trabalho aí. Então se você tiver este designer criando a imagem desse ambiente virtual, conseguindo ajudar na predisposição dos links que vão ter ali, de onde o aluno vai achar uma sala de batepapo, de onde que vai ficar um fórum. Ficar mais organizado isso, eu acredito que vai ser muito bom. Porque às vezes, dentro do próprio Moodle, que eu trabalho com ele há mais de quatro anos, eu me perco em alguns cursos que a gente tem, ou que estou fazendo, ou que estou trabalhando. Âs vezes eu me perco dentro dele procurando alguma coisa. Então, com trabalho de design de participar da elaboração deste ambiente virtual com certeza deve ficar bem melhor. Eu acho que a ideia é essa. O trabalho em rede: o designer, o programador, os professores com conteúdo sugerido também...Na criação bem dentro dessa modalidade, dessa rede interdisciplinar, de criação de espaços colaborativos de educação. Acho que seria muito bacana. (E3)

Perante essas verbalizações, destacamos os comentários do educador E1, que nunca havia experimentado o uso de Ambientes Virtuais de Aprendizagem, mas manifestou o interesse em se aproximar das possibilidades da Educação a Distância. Ao reportarmos ao potencial que o ambiente pode apresentar, podemos considerar que as características que ele apresenta poderão afastar ou aproximar educandos e educadores da Educação a Distância. Podemos admitir que o ambiente pode favorecer a adesão aos estudos ou propiciar a evasão nessa modalidade de ensino. 


\subsubsection{3}

\section{A relação entre AVAs e o campo do Design na visão dos designers}

Assim como perguntamos aos gestores e educadores, indagamos aos designers participantes se o campo do Design pode contribuir para a construção de novos Ambientes Virtuais de Aprendizagem e/ou para a realização de melhorias nos existentes.

Eu acho que sim, principalmente nessa parte de arquitetura de informação, de como você vai organizar essas opções todas, como você vai colar ícones e onde você vai posicionar os botões. Eu acho que com certeza, certamente. Assim, estou falando só de uma esfera muito material do design. Nessa parte eu acho que totalmente, assim. E além, até pensando em que outras formas ele pode ter, até interações mais livres, que nem aquela que eu tava falando antes. Eu não tenho resposta para isso, mas foi uma dificuldade de cara. Como é que eu vou fazer uma discussão em que não se tenha resposta certa? O computador prevê você vai botar um caixa para o cara escrever o que ele quiser tem que ter a resposta certa. Não. Às vezes não tem. Então, pensar essas interações assim... (D1)

Com certeza. Principalmente porque são dois momentos que a gente está considerando. Seria um professor, por exemplo, ou um gestor de um desses cursos postar essa informação, registrar essa informação e organizá-las também, né. Num segundo momento um aluno, alguém que vá absorver isso, ter a mesma facilidade em localizar e fazer um download ou consumo dessa informação. Então acho que você considerar isso como necessidade e priorizar o que é mais importante... Talvez colocar de início essas informações de uma forma mais legível, com ícones que facilitem a organização por data, por área de interesse. Certamente seria algo proposto por um designer gráfico ou alguém que conheça de programação e saiba priorizar essa informação seria mais que ideal. (D2).

Acredito que sim. Principalmente pensando na questão da usabilidade e no perfil das pessoas que vão estar usando este recurso. $\mathrm{O}$ acesso à Educação a Distância é interessante de facilitar as pessoas acesso à educação. Mas se não for de uma coisa na forma clara, mais limpa possível, mais objetiva, pode ser que uma pessoa venha ter dificuldades. Então, eu acho que design, ele pode entrar com isso, auxiliando. Colaborando. (D3)

A partir dessas verbalizações, notamos de forma unânime que os designers participantes coadunam em afirmar a importância do campo do Design na construção de Ambientes Virtuais de Aprendizagem. 
Com essa constatação, questionamos os designers sobre quais as perspectivas que enxergam para o futuro dos Ambientes Virtuais de Aprendizagem e quais alterações esperam ou anseiam que ocorram com os ambientes. Demonstraram suas expectativas conforme segue:

[...] À medida que populariza a banda larga cada vez mais, eu imagino que se tenha uma tendência maior pelo vídeo, né? [...] E assim, isso, eu acho que o vídeo, como eu falei, na educação ele ajuda. E eu acho que talvez esse lado do Edmodo, eu achei interessante, ele ter cara de rede social. Gostaria de vê-lo funcionando com os alunos respondendo, como é que fica uma dinâmica. Porque também, eu falei primeiro do vídeo. Isso é até uma facilidade porque também as pessoas estão usando mais o celular...O 4G está melhor na rua. Mas olhando esse lado da rede social, por que eu achei isso interessante? Porque talvez ali tenha uma resposta, assim bem básica. Porque ninguém precisa inventar nada novo. Para você ter essa discussão livre, dos comentários, que nem uma sala de aula mesmo. Por exemplo: o que vocês acham desse quadro aqui? Há eu vejo tristeza... ah não eu vejo isso. E inicia uma conversa e não ser assim é... Deixa eu falar minha implicância às vezes com o ensino a distância, a maneira como eu já lidei com ele hoje [...]. Às vezes eu fico com a sensação de que o professor elaborava as aulas, uma aula perfeita. O cara faz aquela aula assim que... o professor quando vai em sala de aula de novo, todo dia, cada dia sai um pouquinho diferente. E ele também vai indo depende da interação com a turma... ali o cara pode fazer uma performance perfeita seja no vídeo ou no texto. E aquele troço fica meio estanque, porque o outro... você às vezes... aquilo era ótimo, mas depois de 5 anos, o pessoal às vezes... [...]. E aí tem os tutores... tá tudo bem, tem os tutores que vão lá dar aula. Mas não é o tutor que fez esse conteúdo. [...]. Essa para mim é o lado negro do ensino a distância. Esse engessamento. [...]. Assim como eu visualizei ali no Edmodo, não sei se é isso. Eu acho que seria uma coisa legal. Tanto como aluno ou se eu vier mesmo a ser professor. [...] E é isso. $\mathrm{E}$ o que eu diria de futuro seria isso: - mais possibilidades de ter essa troca e talvez essa... Eu acho que o vídeo vai ficar mais predominante. Até se tiver vídeo como opção de chegar até um vídeo em que a pessoa possa clicar no vídeo. Sei lá, daqui a pouco eu acho que pode estar acontecendo esse tipo de coisa. (D1)

A tendência de forma geral, não só na Educação, mas como todo tipo de serviço que a gente tem, é migrar para este tipo de acesso. Para a questão digital realmente. Agora acho que é um processo que precisa ser modificado por ponto de vista do usuário. Claro que precisa ter uma rotina de acesso e familiarizar com este tipo de ferramenta. Mas a própria ferramenta precisa se tornar mais intuitiva, mais convidativa, menos burocrática para considerar esse acesso. [...]. Para orientar até quem não faz um uso frequente de tecnologia. Porque a pessoa pode fazer um curso a distância sem ser adepto de tecnologia, enfim. (D2) 
[...] Acho que se for mais dinâmico, mais próximo... Por exemplo, tem as videoaulas que auxiliam muito. Porque se, além do texto, tiver fóruns, pode conseguir aproximar mais as pessoas. Às vezes uma videoconferência, com várias pessoas em vários lugares, às vezes é uma oportunidade mais interessante. (D3)

Percebemos nas expressões dos designers a expectativa por ambientes que apresentem a possibilidade de estimular a interação entre os usuários e possuam uma interface simples, intuitiva e convidativa a educadores e educandos.

Com isso, perguntamos aos designers se conhecem algum designer que já atuou na construção ou na elaboração de ambientes ou cursos na modalidade a distância. Os designers D2 e D3 afirmaram que não conhecem. Já D1 sinalizou que conhece e atua em uma equipe composta por designers, conforme expôs em seu comentário:

Todo mundo da minha equipe é designer, ou formado em produção gráfica. No setor, como eu falei, de material impresso, porque acaba que a gente faz os livros e os PDFs, ou uma ilustração ou outra que vai ser usada no site. De ilustração nós temos seis ilustradores, somos seis ilustradores. Designers que atuam mais na área de diagramação fazendo o design de página, seja do livro ou seja de uma coisa que vai ser uma ebook, aí não são ilustradores, são designers. Aí deve ter... eu tenho até de contar... Olha eu acho que são dez, cerca de dez. Aí você tem dois produtores gráficos, um é formado em design também e é basicamente assim... Aí o resto não, tem colegas que são professores, pessoas das letras, pessoas da revisão, de edição de texto, tem pessoas que trabalham com vídeo, mas designer eu acredito que doze. (D1)

Após essa constatação, perguntamos aos designers se acreditam que eles podem atuar na elaboração ou na configuração de Ambientes Virtuais de Aprendizagem. Destacamos apenas as expressões do D1, que expôs de modo contextualizado a sua visão:

[...] eu acho que eu poderia contribuir mais e fico, às vezes o pessoal já chegou com uma ilustração pronta que se eu tivesse sido convidado a participar lá do início da reunião com professor e com o design institucional eu poderia de repente até apresentar uma outra solução visual, ou outro caminho. E a maneira como fizeram o fluxograma lá eu acho que eles até estão abertos a isso porque eu também comecei a perturbar um pouco para participar e tudo. Eu acho que é mais interessante, porque se você... E aí o designer ele não fica só aquele cara que, hora faz isso, hora faz aquilo, digamos assim. Ele já tá dando vida a soluções que outras 
pessoas não designers criaram. Até porque se você tá pensando em uma aprendizagem cada vez mais visual, mesmo que ensino a distância... mesmo que você faça uma aula toda de texto, toda a interface dessas plataformas é visual, né? Você vai lidar com ícones e tudo. Então quer dizer, eu acho que é importante sim, a gente participar. E tem que querer também. É isso sim acho, as vezes as pessoas já estão acostumadas a trabalhar de um jeito e não querem mais mudar também. (D1)

Isto posto, perguntamos aos designers se gostariam de acrescentar alguma informação, comentário, ou descrever algo mais sobre a experiência de uso dos três ambientes. Os designers D2 e D3 expuseram seus comentários e depoimentos:

Não, é isso aí, eu falei pra caramba! (D1)

Um comentário até pessoal de fazer as duas primeiras tentativas e não ser bem-sucedido nelas. Tentar utilizar e não conseguir avançar de alguma forma. Isso considerando que eu já utilizo, já trabalho com informática, com ferramentas, softwares diferenciados e já até um certo tempo. Então eu não imaginei que fosse tão burocrático. Achei que seria mais intuitiva. A minha experiência em utilizar de forma geral foi meio frustrante, pois só um dentre os três casos conseguir desenvolver. (D2)

Bom eu tenho. Quando for desenvolvido um projeto de curso a distância, eu acho que quem for desenvolver tem que ter muito claro que existem dois perfis de pessoas, dois públicos que vão estar usando este ambiente. Um é profissional que vai incluir as informações para os seus alunos e outros são os alunos. São perfis diferentes. São pessoas diferentes. Então quando eu falo que precisa ser mais claro, mais objetivo, mas dinâmico, é para facilitar. Isso para que o professor não ache chato, entediante, difícil de incluir a matéria e que o aluno também não tenha dificuldade em encontrar as informações, para que ele (aluno) não perca a paciência. Porque num primeiro momento eu perdi um pouco a paciência. Falei: - não estou achando as informações. Então, uma primeira impressão ruim pode desestimular as pessoas a querer usar. (D3)

O designer D2 explicitou a sua dificuldade em utilizar os ambientes Moodle e EDX, alertando para a necessidade de tornar os ambientes mais fáceis e intuitos do ponto de vista da interface. Já a designer D3 alertou para a possibilidade de ocorrer a adesão ou evasão de cursos a distância devido às características que os AVAS podem apresentar. 


\subsubsection{4}

\section{A síntese na relação entre AVAs e o campo do Design}

As verbalizações dos gestores, educadores e designers indicam a necessidade de uma aproximação entre os campos do Design e da Educação a Distância no âmbito da construção e intervenções em Ambientes Virtuais de Aprendizagem. Notamos um consenso nas opiniões dos nove entrevistados acerca do potencial do campo do Design em participar na construção de novos Ambientes Virtuais de Aprendizagem. Constatou-se também uma lacuna entre os referidos campos e a incipiência da atuação de designers no campo da Educação a Distância.

A partir dos comentários, reconhecemos a expectativa dos entrevistados por ambientes que possibilitem a convergência de mídias, sejam fáceis de utilizar e acompanhem as tendências das ferramentas contemporâneas. Percebemos também o anseio por ambientes com possibilidades de estimular a interação entre os educandos, educadores e conteúdo, além de uma interface simples, intuitiva e convidativa.

\section{3 \\ Considerações parciais}

O presente capítulo teve como objetivos identificar e entender as concepções, significados e sentidos atribuídos por gestores, educadores e designers aos Ambientes Virtuais de Aprendizagem em alinhamento com o quinto objetivo específico da pesquisa. Pudemos reconhecer, a partir das verbalizações de entrevistados, as possibilidades de aproximação entre os campos do Design e da Educação a Distância no âmbito da construção e intervenções em Ambientes Virtuais de Aprendizagem.

A partir da participação dos nove voluntários, conseguimos identificar a demanda por ambientes planejados e capazes de favorecer as práticas de interação entre educadores, educandos e conteúdo nos AVAs, além de facilitar o uso de gêneros multimodais. Notamos também um consenso nas opiniões dos nove participantes que reconhecem o potencial do campo do Design em participar da construção de novos Ambientes Virtuais de Aprendizagem. Constatou-se a existência de uma lacuna entre os referidos campos e a incipiência da atuação de designers no campo da Educação a Distância. 
A partir dos comentários, reconhecemos, na expectativa dos entrevistados, a demanda por ambientes que possibilitem a convergência de mídias e a introdução de estratégias que valorizem o uso de tecnologias contemporâneas. Como visto, os entrevistados também sinalizaram um anseio pela criação de ambientes fáceis de utilizar e com uma interface convidativa e intuitiva.

Essencialmente, pudemos identificar a necessidade de aproximação entre os campos do Design e da Educação a Distância na construção e intervenções em Ambientes Virtuais de Aprendizagem. 


\section{7 \\ Considerações finais}

Por meio desta pesquisa, buscamos verificar as aproximações e distanciamentos entre os campos do Design e da Educação a Distância. De modo particular, nos debruçamos a investigar as possíveis interações, sentidos e significados atribuídos aos Ambientes Virtuais de Aprendizagem. Assim, assumimos como marco teórico nesta pesquisa os conceitos de interação abordados por Jean Piaget (1974) e Lev Vygotsky (1984), (1989); e as concepções de Significados e Sentidos abordados por Mikhail Bakhtin (2006).

O nosso objetivo com esta pesquisa foi compreender as concepções dos agentes da $\mathrm{EaD}$ (gestores, designers, designers instrucionais, docentes, discentes, etc.) acerca do que potencializa o AVA como suporte de significação e interação que media a relação educador-educando. Tivemos assim um percurso em que buscamos, inicialmente, realizar um levantamento bibliográfico dos conceitos e relações possíveis entre Design e Educação a Distância. Em seguida, fizemos uma análise do panorama de processos de concepção, apropriação e utilização de AVAs partir do ranking de instituições ligadas ao campo do Design. Posteriormente, em uma terceira etapa, realizamos um estudo por meio da aplicação de questionários destinados a designers instrucionais, para compreender o potencial de significação e interação nas situações de uso por comunidades de ensino-aprendizagem. $\mathrm{Na}$ quarta etapa, realizamos uma breve análise em alguns Ambientes Virtuais de Aprendizagem com o intuito de classificá-los e categorizá-los pelo viés da configurabilidade e multimodalidade. E finalmente, na quinta etapa desta pesquisa, foi possível realizar entrevistas junto aos agentes da $\mathrm{EaD}$ (gestores, educadores e designers) com o intuito de avaliar os usos, significados e sentidos atribuídos aos ambientes.

No capítulo 2, fizemos uma reflexão acerca dos conceitos previstos na condução da pesquisa e discorremos sobre as possibilidades de interseção entre os campos da Educação a Distância e do Design. Apresentamos os principais

Ambientes Virtuais de Aprendizagem, a partir de iniciativas nacionais e 
internacionais, na concepção de plataformas para o ensino a distância. Discorremos sobre os conceitos de interação, mediação, significado e sentidos a partir do aporte teórico em Piaget (1974); Vygotsky (1984), (1989) e nas formulações de Bakhtin (2006).

No terceiro capítulo desta pesquisa, foi possível constatar que as instituições classificadas pelo Red Dot Design e pelo QS World University optam pelo uso de Ambientes Virtuais de Aprendizagem comumente reconhecidos, revelando uma incipiência de alternativas na construção e apropriação de novos AVAs. O levantamento também pôde demonstrar que as opções mais utilizadas pelas instituições de ensino envolvidas com a formação em Design são, respectivamente, os ambientes Moodle e Blackboard, na classificação Red Dot Design; e os ambientes EDX e Coursera, na classificação QS World University.

Constamos também que os ambientes EDX e Coursera, embora apresentem características de democratização do acesso ao conhecimento, demonstram um viés caracterizado pela concepção de formação massiva de educação, assumindo níveis restritos no que se refere aos critérios e níveis de configuração. Já os ambientes Moodle e Blackboard, por apresentarem uma maior diversidade de funcionalidades, demandam de educadores e educandos um aprendizado mais detalhado para seu uso. Foi possível também notar como um ponto positivo os Ambientes Virtuais de Aprendizagem apresentarem certa flexibilidade na configuração de sua interface, permitindo aos usuários adequá-los às suas necessidades, como no caso do Moodle e Blackboard.

Outra constatação, como um ponto positivo, é o fato de alguns ambientes apresentarem certa simplicidade de utilização com um layout simples, amigável, como no exemplo do Edmodo e, assim, reconhecer ser favorável e oportuna uma aproximação interdisciplinar entre os campos do Design e da EaD com vistas a otimizar estratégias de concepção e construção de AVAs adequados aos processos de ensino-aprendizagem.

No quarto capítulo desta pesquisa, realizamos um levantamento de informações junto ao grupo de 27 designers instrucionais pesquisados. Foi possível revelar que a construção de AVAs ainda está incipiente no âmbito da área de Design Instrucional. De modo geral, encontram-se iniciativas relacionadas à "configuração" da plataforma Moodle tradicionalmente conhecida. Nas concepções e percepções dos designers instrucionais pesquisados, a disposição de recursos e 
funcionalidades nos ambientes colabora para a promoção de situações interativas e favorece processos educacionais.

Neste sentido, reconhecemos que a construção de AVAs é algo capaz de favorecer as situações interativas em processos de ensino-aprendizagem. No entanto, nos foi revelado que a construção de ambientes adequadamente planejados não é o fator determinante para que se dê o aprimoramento de processos de interação entre educador-educandos e educandos-colegas.

Por meio do quinto capítulo desta tese, foi possível constatar que os ambientes Moodle e Blackboard apresentam características mais flexíveis quanto ao grau de configuração de seu layout e de disponibilidade de funcionalidades. Observamos que, de modo particular, o Moodle, pela sua flexibilidade em disponibilizar código aberto, possibilita a configuração sob demanda pelos gestores em cursos na modalidade a distância, de modo a viabilizar uma interface gráfica simples e amigável aos tutores e educandos-usuários. Os ambientes Moodle e Blackboard oferecem a possibilidade de organização do espaço de modo flexível, tanto na inserção de recursos e funcionalidades quanto na colocação das atividades dos cursos. Notamos certa facilidade de localização e consulta a materiais, atividades e postagens feitas em longo prazo.

Quanto aos ambientes EDX e Coursera e Edmodo, percebemos que se trata de propostas com menor margem de configuração. Nesses ambientes há restrições na (re)configuração e organização do espaço de interação. E, de modo particular, no Edmodo, há ainda certa dificuldade em localizar atividades e materiais postados em longo prazo em virtude da sobreposição de postagens na Linha do Tempo (Timeline).

Nos ambientes Moodle e Blackboard, há várias alternativas para se realizar a avaliação do aprendizado dos educandos assim como a visualização detalhada das notas de educandos. Em contrapartida, no Edmodo reconhecemos os limites no detalhamento de notas atribuídas aos educandos. Entretanto, o fato de o ambiente Edmodo ser similar às redes sociais digitais favorece ações de compartilhamento, comentários e curtidas das postagens de educadores e educandos.

Ainda no capítulo 5 desta pesquisa, verificamos aspectos relacionados à multimodalidade nos ambientes avaliados. Foi possível identificar que os cinco ambientes analisados oferecem uma diversidade de opções no que se refere aos processos de comunicação, expressão e interação. Por meio do uso dessas diferentes 
opções nas funcionalidades Fórum, Fórum de Discussão, Discussão e Mural de Postagens, reconhecemos que se trata de uma ferramenta multimodalmente constituída, e não somente a alfabética.

Por meio de nossa análise preliminar dos cinco ambientes, foi possível reconhecer o potencial dos ambientes Moodle e Blackboard, que disponibilizam ao usuário a opção de inserir vídeos e arquivos de áudio, incorporados à página, sem a necessidade de links externos. Além disso, em tais ambientes encontramos a possibilidade de incluir emojis, possibilitando uma maior interação verbal humana.

No sexto capítulo tivemos como objetivos identificar e entender as concepções, significados e sentidos atribuídos por gestores, educadores e designers aos Ambientes Virtuais de Aprendizagem. Pudemos reconhecer, a partir das verbalizações de entrevistados, as possibilidades de aproximação e estreitamento interdisciplinar entre os campos do Design e da Educação a Distância.

Com a participação dos nove voluntários, conseguimos identificar a demanda por ambientes planejados e capazes de favorecer práticas de interação entre educadores, educandos e conteúdo nos AVAs, além de facilitar o uso de gêneros multimodais. Notamos também um consenso nas opiniões dos nove participantes, que reconhecem o potencial do campo do Design em participar da construção de novos Ambientes Virtuais de Aprendizagem. Certificamos que existe uma lacuna entre os referidos campos e a incipiência da atuação de designers no campo da Educação a Distância.

Pelos comentários, vimos uma expectativa de ambientes que possibilitem a convergência de mídias e a introdução de estratégias que valorizem o uso de tecnologias contemporâneas. Além disso, conforme visto nesta pesquisa, os entrevistados também sinalizaram um anseio pela criação de ambientes fáceis de se utilizar e com uma interface convidativa e intuitiva.

Resgatando os nossos 04 (quatro) pressupostos nesta pesquisa é possível confrontá-los com os achados encontrados até aqui. Suspeitávamos que: a) cursos de Design nacionais utilizavam AVAs projetados adequadamente com foco nas relações de ensino-aprendizagem; b) cursos de Design internacionais utilizavam AVAs projetados adequadamente com foco nas relações de ensino-aprendizagem; c) designers instrucionais qualificavam AVAs quanto ao potencial de significação e interação nas situações de uso por comunidades de ensino-aprendizagem; e d) Instituições de Ensino Superior com oferta de cursos de Design disponibilizavam 
para a comunidade AVAs não configuráveis, enquanto os designers instrucionais qualificavam AVAs configuráveis como melhores para atender às demandas da comunidade.

Os nossos dois primeiros pressupostos puderam ser refutados, considerando que tanto nas instituições de ensino superior de Design nacionais e internacionais, raramente são ofertados cursos na modalidade a distância e quando essas ofertam, tendem a priorizar o uso de ambientes comumente conhecidos, como o Moodle. Não há iniciativas de (re)construção de novos ambientes virtuais de aprendizagem no âmbito do Design.

No caso dos nossos pressupostos "c" e "d" identificamos um contexto no qual os designers instrucionais utilizam prioritariamente o ambiente Moodle e qualificavam AVAs quanto ao potencial de significação e interação nas situações de uso por comunidades de ensino-aprendizagem. No entanto, geralmente as Instituições de Ensino Superior disponibilizam para a comunidade AVAs com possibilidades restritas de configuração.

Sustentamos e reconhecemos com o desenvolvimento de nossa pesquisa a necessidade de uma aproximação entre os campos do Design e da Educação a Distância na (re)construção de novas propostas de Ambientes Virtuais de Aprendizagem capazes de favorecer a interação entre educador-educando e o surgimento de novas práticas educativas. 


\section{8 Referências bibliográficas}

ACADEMYART. Online Education. Disponível em: $<$ https://www.academyart.edu/online-education/>. Acesso em: 03 nov. 2017.

BAKHTIN, Mikhail. Marxismo e filosofia da linguagem. 12. ed. São Paulo: Hucitec, 2006.

BAKHTIN, Mikhail. O autor e a personagem na atividade estética. In: BAKHTIN, M. Estética da criação verbal. Trad. Paulo Bezerra. 4 ed. São Paulo: Martins Fontes, 2003, p.3-192.

BARDIN, L. Análise de conteúdo. São Paulo: Edições 70, 2011.

BEHAR, Patrícia Alejandra. Modelos Pedagógicos em Educação a Distância. Porto Alegre: Artmed, 2009.

BOMFIM, Gustavo A.; PORTINARI, Denise B. Epistemologia do Design. In: COUTO, Rita Maria de Souza; FARBIARZ, Jackeline Lima; NOVAES, Luiza. Gustavo Amarante Bomfim: uma coletânea. Rio de Janeiro: Rio Book's 1ª Edição 2014.

BRASIL. Ministério da Educação 2015. Compreendendo o OAS. Disponível em: <http://webeduc.mec.gov.br/linuxeducacional/curso_le/ modulo4_4_1.html>. Acesso em: 5 jan. 2015.

CAPTERRA. Disponível em: <http://www.capterra.com/learningmanagement-system-software /\#infograpic>

CARDOSO, Rafael. Uma introdução à história do design. 2. ed. São Paulo: Edgard Blucher, 2004.

CASTELLS, Manuel. A sociedade em rede. São Paulo: Paz e Terra, 2009. CORREA, Juliane. Estruturação de Programas em EAD. In Educação a distância: Orientações Metodológicas. Corrêa, Juliane (Org.) - Porto Alegre: Artmed, 2007.

COURSE SITES. Disponível em: <https://www.coursesites.com/webapps/ portal/frameset.jsp> 2017.

COURSERA. Sobre. Disponível em: https://www.coursera.org/about/> Acesso em: 16 mar. 2015.

COUTO, R. M. S. (Org.); OLIVEIRA, A. J. (Org.). Formas do Design: Por uma metodologia interdisciplinar. Rio de Janeiro: 2AB, 1999.

DIAS, Cynthia Macedo; FARBIARZ, Jackeline Lima. Convivencialidade, institucionalização e Design: lugares e relações mediados por ambientes online no ensino e aprendizagem de projeto. 2013. 194 f. Dissertação 
(Mestrado). Pontifícia Universidade Católica do Rio de Janeiro, Departamento de Artes e Design, 2013.

DOUGIAMAS, Martin. História do Moodle. Disponível em: $<$ https://docs.moodle.org/all/pt_br/História_do_Moodle>. Acesso em 19 jun. 2015.

EDMODO. About Edmodo. Disponível em: https://www. edmodo.com/ about. Acesso em: 14 fev. 2015.

EDX. About. Disponível em: https://www. edx.org/about-us. Acesso em: 14 mar. 2015.

FILATRO, Andrea. Design instrucional contextualizado: Educação e Tecnologia. São Paulo: Editora SENAC, 2004.

FILATRO, Andrea. Design instrucional na prática. São Paulo: Pearson Education do Brasil, 2008.

FLICK, Uwe. Desenho da pesquisa qualitativa. Tradução de Roberto Cataldo Costa; consultoria, supervisão e revisão técnica desta edição Dirceu da Silva. Porto Alegre: Artmed, 2009.

FORTY, Adrian. Objetos de desejo - design e sociedade desde 1750. Tradução de Pedro Maia Soares - São Paulo: Cosac Naify, 2013. Título original: Objects of desire - design and society since 1970.

FREE SOFTWARE FOUNDATION. Disponível em:<https://www.fsf.org/ptbr> Acesso em 14 mar. 2016.

FREITAS, Maria Teresa de Assunção. Sites construídos por adolescentes: novos espaços de leitura/escrita e subjetivação. Cad. CEDES. Campinas, v. 25, n. 65, p. 87-101, Apr. 2005.

GIDDENS, Anthony. As consequências da modernidade. Tradução de Raul Fiker. São Paulo: Editora UNESP, 1991. Título original em inglês: The Consequences of Modernity.

HESKETT, John. Design. São Paulo: Ática, 2008.

HUMBLE, Jez; FARLEY, David. Entrega Contínua: como entregar software de forma rápida e confiável. Tradução: Marco Aurélio Valtas Cunha. Porto Alegre: Bookman. 2014. Título Original: continuous delivery: reliable software releases through build, test, and deployment automation.

IEEE, L.T.S.C.; IEEE Standard for learning object medadata, 2002. Disponível em:< http://ltsc.ieee.org/wg12/index.html> Acesso em: 28 set. 2013.

INEP. Censo Escolar da Educação Superior 2016. Brasília, DF: Ministério da Educação / Instituto Nacional de Estudos e Pesquisas Educacionais Anísio Teixeira, 2016. Disponível em: http://download.inep.gov.br/educacao_superior/censo_superior/apresenta cao/2016/apresentacao_censo_educacao_superior.pdf >. Acesso em: 19 set. 2017.

LAKATOS, Eva Maria. Fundamentos de metodologia científica. 5.ed. São Paulo: Atlas 2003. 
LARC. Laboratório de Arquitetura e Redes de Computadores. Disponível em: <http://www.larc.usp.br/projetos-finalizados/>. Acesso em 04 dez. 2016.

LÉVY, Pierre. Cibercultura. Tradução de Carlos Irineu da Costa. São Paulo: Editora 34, 1999.

LYOTARD, Jean-François. A condição pós-moderna. Trad. de Ricardo Corrêa Barbosa. Rio de Janeiro: José Olympio, 2002.

MARCONI, M. A.; LAKATOS, E. M. Fundamentos de metodologia científica. 5 ed. São Paulo: Atlas, 2003.

MATTAR, João Augusto. Ambientes Virtuais de Aprendizagem 3D online: ensinando e aprendendo no Second life. In: Congresso Internacional ABED de Educação a Distância, 14, 2008, Santos. Anais... Santos, ABED, 2008. Disponível em: <www.abed.org.br/congresso2008/ tc/532008123812PM.pdf>. Acesso em: 09 abr. 2016.

MOODLE. About Moodle. Disponível em: <https://docs.modlle.org/31en/ About_Moodle>. Acesso em 14 mar. 2015.

MORAN, J. M. A educação que desejamos: Novos desafios e como chegar lá. São Paulo: Papirus, 2007.

NAKAMURA, Rodolfo. Moodle: Como criar um curso usando a plataforma de Ensino a Distância. São Paulo: Farol do Forte, 2009.

OLIVEIRA, Celina Couto de; COSTA, José Wilson da; MOREIRA, Mercia. Ambientes Informatizados de Aprendizagem: Produção e avaliação de software educativo. Campinas: Papirus, 2001.

OPEN SOURCE INITIATIVE. Disponível em: <http://opensource.org>. Acesso em: 15 mar. 2016.

PAIVA, Vera Lúcia Menezes de Oliveira e. A linguagem dos emojis. Trab. linguist. apl., Campinas, v. 55, n. 2, p. 379-401, ago.2016. Disponível em: <http://www.scielo.br/scielo.php?script= sci_arttext\&pid=S010318132016000200379\&lng=pt\&nrm=iso>Acesso em: 21 jan. 2017.

PALANGANA, Isilda Campaner. Desenvolvimento e aprendizagem em Piaget e Vygotsky: a relevância do social. 6.ed. São Paulo: Summus, 2015.

PESTALOZZI, Johann Heinrich. Antologia de Pestalozzi. Trad. Lorenzo Luzuriaga. Buenos Aires: Losada, 1946.

PIAGET, J. Aprendizagem e conhecimento. Rio de Janeiro: Freitas Bastos, 1974.

PORTUGAL, Cristina. Design, Educação e Tecnologia. Rio de Janeiro: Rio Books, 2013.

RED DOT. Red Dot Design Ranking. Disponível em: <http://www.reddot.sg/en/red-dot-design-ranking/>. Acesso em: 06 out. 2017.

SALVADOR, Pétala Tuani Candido de Oliveira et al. Objeto e ambiente virtual de aprendizagem: análise de conceito. Rev. Bras. Enferm., Brasília, v. 70, n. 3, p. 572-579, jun. 2017. Disponível em: 
$<$ http://www.scielo.br/pdf/reben/v70n3/pt_0034-7167-reben-70-03-0572.pd f>. Acesso em: 16 nov. 2017.

SANTOS, Alisson Rodrigo; MOREIRA, Adelson Fernandes. Contribuições de Bakhtin para constituição e análise de entrevistas e grupos focais. Educação \& Tecnologia, [S.I.], v. 15, n. 3, jun. 2011. ISSN 2317-7756. Disponível em: <https://periodicos.cefetmg.br/index.php/revista-et/article/ view/283>. Acesso em: 03 out. 2017.

SANTOS, Milton. A Natureza do Espaço: Técnica e Tempo, Razão e Emoção. 4. ed. São Paulo: Editora da Universidade de São Paulo, 2006.

SLOODLE. Disponível em: <https://www.sloodle.org>

TANZI NETO, Adolfo; LESSA, Angela Brambilla Cavenaghi Themudo. Arquitetura de ambientes virtuais de aprendizagem sob a ótica dos estudos bakhtinianos. Bakhtiniana, Rev. Estud. Discurso, São Paulo, v. 9, n. 2, p. 164-183, dez. 2014. Disponível em: <http://www.scielo.br/ scielo.php?script=sci_arttext\&pid=S2176-

$45732014000200011 \&$ Ing=pt\&nrm=iso >. Acesso em: 14 jun. 2015.

TORI, Romero. Educação sem distância: as tecnologias interativas na redução de distâncias em ensino e aprendizagem. São Paulo: Editora Senac São Paulo, 2010.

VIGOTSKY, L. S. A formação social da mente. São Paulo: Martins Fontes, 1984.

VYGOTSKY, L. S. O desenvolvimento psicológico na infância. São Paulo: Martins Fontes, 1999.

WALLON, H. As origens do pensamento na criança. São Paulo: Manole, 1986

WALLON, H. A evolução psicológica da criança. São Paulo: Martins Fontes, 2007.

WDO. World Design Organization. Definition of Industrial Design. Disponível em: <http://wdo.org/about/definition/>. Acesso em: 3 dez. 2017. 


\section{9 \\ Apêndices}

\section{Termo de Consentimento Livre e Esclarecido Direcionado a Designers Instrucionais}

Caro(a) Designer Instrucional,

Você está sendo convidado(a) a participar voluntariamente desta pesquisa que tem como objetivo compreender as concepções dos agentes da EaD (gestores, docentes e designers) acerca do que potencializa o AVA como suporte de significação e interação que media a relação educador-educando. Caso concorde em participar deste estudo, você será solicitado a responder a um questionário estruturado com questões de conhecimento sobre o tema em estudo. Os riscos advindos da participação nesta pesquisa são mínimos e estão relacionados a um eventual constrangimento ou desconforto ao responder a algum item. A participação neste estudo é voluntária, não há pagamentos por sua colaboração. Você pode desistir de participar a qualquer momento, sem nenhum prejuízo ou penalidade. Você não estará obrigado a responder a todas as perguntas ou participar de todas as atividades e poderá interromper ou encerrar o preenchimento e/ou participação quando quiser. Os benefícios desta pesquisa estão relacionados à possibilidade de se contribuir para a compreensão das potencialidades dos diferentes recursos digitais no que se refere à apropriação de múltiplas linguagens e por diversificar as estratégias de interação entre educandos, educadores e os materiais didáticos. O questionário está programado para ser preenchido em aproximadamente 30 (trinta) minutos. Os resultados desta pesquisa serão utilizados única e exclusivamente em trabalhos científicos, publicados ou apresentados oralmente em congressos, sendo que serão adotados procedimentos que impeçam sua identificação.

Declaração de consentimento: Declaro que li o texto acima e entendo os objetivos e condições de participação na pesquisa e aceito participar. Ficaram claros para mim 
quais são os propósitos do estudo, os procedimentos a serem realizados, as garantias de confidencialidade, os riscos e benefícios.

Nome do Participante Voluntário:

Contato:

Assinatura do Participante Voluntário:

Local, data e ano:

Nome do Pesquisador:

Contato:

Assinatura do Pesquisador:

Local, data e ano:

Agradecemos sua atenção e valiosa colaboração.

Pesquisadores:

Professor Alecir Francisco de Carvalho - Contato: alecircarvalho@gmail.com Professora Orientadora: Jackeline Lima Farbiarz - Contato: jackeline@ puc-rio.br 


\section{Questionário Direcionado a Designers Instrucionais}

1. Nome e Sobrenome:

2. Idade

3. Titulação

4. Área do curso de graduação

5. Instituição em que estuda(ou) na graduação

6. Área do curso de Pós-Graduação

7. Instituição em que estuda(ou) na Pós-Graduação

8. Trabalha atualmente como Designer Instrucional?

9. Tempo de atuação como Designer Instrucional.

10. Quais os "Lugares" dos Designers Instrucionais na construção de Ambientes Virtuais de Aprendizagem?

11. Quais são as ações concretizadas por você "Designer Instrucional" relacionadas à produção de material impresso, recursos digitais e/ou Ambientes Virtuais de Aprendizagem?

12. Quais metodologias você adota em seu trabalho?

13. Você já trabalhou na construção de Ambientes Virtuais de Aprendizagem? Se sim, qual o nome do Ambiente?

14. Há algum Ambiente Virtual de Aprendizagem que ainda não utilizou, mas em que gostaria de trabalhar? Qual?

15. Em sua opinião, qual é o melhor Ambiente Virtual de Aprendizagem existente?

16. Você conhece Ambientes Virtuais de Aprendizagem produzidos em Três Dimensões "3D", com características de imersão, e/ou aspectos de gamefication "dinâmica de jogos"? Se sim, qual o nome dos Ambientes?

17. Qual o Ambiente Virtual de Aprendizagem você utiliza/utilizou em sua atuação? 
18. Qual a sua avaliação quanto à adequação do Ambiente Virtual de Aprendizagem que você utiliza/utilizou? [Avaliação do AVA]

19. Gostaria de mudar de AVA que você utiliza? (sim ou não). Por quê?

20. Em sua opinião, o que um Ambiente Virtual de Aprendizagem necessita disponibilizar especificamente aos Tutores?

21. Especificamente aos educandos na EaD, o que um Ambiente Virtual de Aprendizagem necessita disponibilizar?

22. Em sua opinião, como os Tutores avaliam a adequação do AVA utilizado? [Avaliação do AVA pelos Tutores]

23. Em sua opinião, como os Educandos avaliam a adequação do AVA utilizado? [Avaliação do AVA pelos Educandos]

24. Quais são as principais ações que um Designer Instrucional pode realizar para favorecer processos de ensino aprendizagem interativos?

25. Os recursos disponíveis aos educandos e tutores apresentam esquemas de comunicação lineares ou não lineares?

26. Os recursos físicos e/ou digitais que você utiliza oferecem aos educandos níveis de interação baixos, médios ou altos? Por quê?

27. Justifique a resposta anterior.

28. Em suas ações, você realiza mudanças no AVA? [Mudanças no AVA]

29. Você participa ou já participou da Criação de algum Ambiente Virtual de Aprendizagem específico? Se sim, exponha brevemente a experiência.

30. Quais critérios você adota ou adotaria na produção do AVAs? Algum modelo, método ou técnica de produção específicos?

31. Você pode informar seu e-mail para contato?

32. Você aceitaria participar de uma breve entrevista sobre o tema? 


\section{Termo de Consentimento Livre e Esclarecido Direcionado a Gestores, Educadores e Designers}

Caro(a) participante,

Você está sendo convidado(a) a participar voluntariamente desta pesquisa que tem como objetivo compreender as concepções dos agentes da $\mathrm{EaD}$ (gestores, docentes e designers) acerca do que potencializa o AVA como suporte de significação e interação que media a relação educador-educando. Caso concorde em participar deste estudo, você será solicitado a responder a uma entrevista semiestruturada com questões de conhecimento sobre o tema em estudo. Os riscos advindos da participação nesta pesquisa são mínimos e estão relacionados a um eventual constrangimento ou desconforto ao responder a algum item. A participação neste estudo é voluntária, não há pagamentos por sua colaboração. Você pode desistir de participar a qualquer momento, sem nenhum prejuízo ou penalidade. Você não estará obrigado a responder a todas as perguntas ou participar de todas as atividades e poderá interromper ou encerrar o preenchimento e/ou participação quando quiser. Os benefícios desta pesquisa estão relacionados à possibilidade de se contribuir para a compreensão das potencialidades dos diferentes recursos digitais no que se refere à apropriação de múltiplas linguagens e por diversificar as estratégias de interação entre educandos, educadores e os materiais didáticos. Os resultados desta pesquisa serão utilizados única e exclusivamente em trabalhos científicos, publicados ou apresentados oralmente em congressos, sendo que serão adotados procedimentos que impeçam sua identificação.

Declaração de consentimento: Declaro que li o texto acima e entendo os objetivos e condições de participação na pesquisa e aceito participar. Ficaram claros para mim quais são os propósitos do estudo, os procedimentos a serem realizados, as garantias de confidencialidade, os riscos e benefícios.

Nome do Participante Voluntário:

Contato: 
Assinatura do Participante Voluntário:

Local, data e ano:

Nome do Pesquisador:

Contato:

Assinatura do Pesquisador:

Local, data e ano:

Agradecemos sua atenção e valiosa colaboração.

Pesquisadores:

Professor Alecir Francisco de Carvalho - Contato: alecircarvalho@gmail.com

Professora Orientadora: Jackeline Lima Farbiarz - Contato: jackeline@puc-rio.br 


\section{Roteiro de Entrevista Direcionado a Gestores, Educadores e Designers}

\section{Caracterização do Participante}

1. Qual é a sua formação?

2. (Para Gestores e Educadores): Quanto tempo de atuação em Cursos ou Programas de Educação a Distância? (Para Designers): Você já fez cursos ou participou da elaboração de cursos na modalidade a distância?

3. Como é ou foi a sua atuação na Gestão de Cursos ou Programas de Educação a Distância?

4. Você já atuou na configuração ou customização de Ambientes Virtuais de Aprendizagem?

5. Quais os Ambientes Virtuais de Aprendizagem você já utilizou em cursos de Educação a Distância?

6. Em uma escala de 1 a 5, qual o seu grau de familiaridade no uso das TICs para Educação a Distância - sendo 1 para "pouca familiaridade" e 5 para "muita familiaridade"?

\section{A utilização dos Ambientes Virtuais de Aprendizagem nesta pesquisa}

7. Entre os três Ambientes Virtuais de Aprendizagem disponíveis para sua utilização, quais já conhecia?

8. A utilização dos Ambientes Virtuais de Aprendizagem transcorreu da maneira como você pretendia?

9. Quais as dificuldades encontradas durante a utilização?

10. Quais as facilidades encontradas durante a utilização?

11. Como foram feitas a identificação e a localização das funcionalidades nos ambientes utilizados?

12. Como você planejou a aula e as atividades nos Ambientes Virtuais de Aprendizagem? 
13. Descreva um pouco mais sobre a experiência de utilizar os três Ambientes Virtuais de Aprendizagem.

\section{A avaliação dos Ambientes Virtuais de Aprendizagem nesta pesquisa}

14. A disposição e a organização das funcionalidades nos Ambientes Virtuais de Aprendizagem são adequadas para realizar cursos na modalidade a distância?

15. Entre os três Ambientes Virtuais de Aprendizagem que você experimentou, qual deles você reconhece como o mais fácil de utilizar? E o mais difícil?

16. Na sua concepção, quais critérios precisam ser considerados na escolha de Ambientes Virtuais de Aprendizagem?

17. Entre os três Ambientes Virtuais de Aprendizagem disponíveis para sua utilização, qual deles melhor oferece as funcionalidades adequadas a cursos de Educação a Distância?

\section{Relação Ambientes Virtuais de Aprendizagem e o campo do Design}

18. Na sua concepção, o Design pode contribuir na construção de novos e/ou na realização de melhorias em Ambientes Virtuais de Aprendizagem existentes? Explique sua resposta.

19. Que perspectivas você tem para o futuro dos Ambientes Virtuais de Aprendizagem e quais alterações você espera ou anseia?

20. (Para Gestores e Educadores): Em sua atuação na Educação a Distância, você já trabalhou na equipe com designers? Se sim, qual era a atuação dos designers? (Para Designers): Você conhece algum designer que já atuou na construção ou na elaboração de cursos na modalidade a distância?

21.(Para Gestores e Educadores): Nessa experiência, você acredita que essa atuação deveria ser diferente? Por quê? (Para Designers): Você acredita que os designers podem atuar na elaboração ou na configuração de Ambientes Virtuais de Aprendizagem?

22. Você gostaria de acrescentar alguma informação ou comentário, ou descrever algo mais sobre a experiência de uso desses ambientes? 


\section{Orientações ao Participante da Pesquisa}

Você está convidado a colaborar em nossa pesquisa cujo objetivo é "Compreender as concepções dos agentes da EaD acerca do que potencializa o AVA como suporte de significação e interação que media a relação professor-aluno". Sua contribuição será de grande importância para que busquemos melhores instrumentos para as relações educacionais a distância.

Assim, pedimos que você elabore uma aula com o tema "Estudo sobre as Cores" em cada um dos três ambientes a seguir: EDX, Moodle e EDMODO. Você pode optar por não produzir conteúdo, podendo copiar e/ou anexar arquivos disponíveis na internet e incorporá-los às suas aulas. O mais importante é fazer uso das ferramentas em suas potencialidades.

É importante que suas aulas, criadas nos ambientes, contenham algum recurso/estratégia para a avaliação do aprendizado dos estudantes. A proposta é que você nos relate posteriormente as suas impressões e percepções acerca dos ambientes.

Enfatizamos que nosso interesse de pesquisa é sobre a elaboração dos ambientes e não sobre o conteúdo de suas aulas. Por isso, não estará em jogo a questão da autoria, pois as aulas servirão apenas como material de estudo e serão posteriormente excluídas. Você não será identificado em nossa pesquisa e suas aulas não serão publicadas.

O período para criação das aulas é de (uma semana).

Agradecemos antecipadamente a sua participação!

Para acessar o Ambiente EDX: alecir-professor.moocando.com.br (Clicar em SIGN IN) - Seu login é: xxxx@gmail.com e sua senha: *******

Para acessar o Ambiente Moodle: alecir.com/moodle (Clicar em Acessar) - Seu login é: xxxx e sua senha: ******* 
Para acessar o Ambiente EDMODO: www.edmodo.com

(Clicar em Login) - Seu login é: xxxx @ gmail.com e sua senha: ******* 